$$
\begin{aligned}
& \text { UNIVERSIDADE DE SÃO PAULO } \\
& \text { INSTITUTO DE PSICOLOGIA }
\end{aligned}
$$

CRISTIANE DA SILVA GERALDO FOLINO

Sobre dores e amores: caminhos da tristeza materna na elaboração psíquica da parentalidade 
CRISTIANE DA SILVA GERALDO FOLINO

\section{Sobre e dores e amores: caminhos da tristeza materna na elaboração psíquica da parentalidade}

(Versão Corrigida)

Tese apresentada ao Instituto de Psicologia da Universidade de São Paulo para obtenção do título de Doutora em Psicologia.

Área de concentração: Psicologia Escolar e do Desenvolvimento Humano

Orientadora: Prof $^{\mathrm{a}} \mathrm{Dr}^{\mathrm{a}}$ Audrey Setton Lopes de Souza

São Paulo 2014 
Autorizo a reprodução e divulgação total ou parcial deste trabalho, por qualquer meio convencional ou eletrônico, para fins de estudo e pesquisa, desde que citada a fonte.

Catalogação na publicação

Biblioteca Dante Moreira Leite

Instituto de Psicologia da Universidade de São Paulo

Folino, Cristiane da Silva Geraldo.

Sobre dores e amores: caminhos da tristeza materna na elaboração psíquica da construção da parentalidade / Cristiane da Silva Geraldo Folino; orientadora Audrey Setton Lopes de Souza. -- São Paulo, 2014.

$212 \mathrm{f}$.

Tese (Doutorado em Psicologia Escolar e do Desenvolvimento Humano) - Instituto de Psicologia da Universidade de São Paulo.

1. Depressão pós-parto 2. Baby blues 3. Psicanálise 4. Relações mãe-criança 5. Puerpério I. Título. 
FOLINO, C. S. G. Sobre dores e amores: caminhos da tristeza materna na elaboração psíquica da parentalidade. Tese apresentada ao Instituto de Psicologia da Universidade de São Paulo para obtenção do título de Doutora em Psicologia.

Aprovada em:

Banca Examinadora

Prof. Dr. instituição:

julgamento: assinatura:

Prof. Dr. instituição:

julgamento: assinatura:

Prof. Dr. instituição:

julgamento: assinatura:

Prof. Dr. instituição:

julgamento: assinatura:

Prof. Dr. instituição:

julgamento: assinatura: 
A meu marido e a meus filhos. 


\section{AGRADECIMENTOS}

Às participantes da pesquisa, devo meu maior agradecimento. Sem elas, não teria tido acesso à preciosidade do material que contém os depoimentos e as vivências analisadas neste trabalho. Junto com seu bebê, abriram as portas de sua casa e me deixaram testemunhar esse tempo difícil e potencialmente fecundo de sua vida.

À $\operatorname{Prof}^{a} \operatorname{Dr}^{a}$ Audrey Setton Lopes de Souza, que mais de uma vez me ajudou a olhar os fenômenos com profundidade e riqueza, tomando parte importante em minha formação como pesquisadora psicanalítica.

Aos colegas do grupo de orientação, pelas trocas profícuas e pelo apoio mútuo.

Aos queridos amigos e colegas que me apoiaram em mais uma experiência nos caminhos da vida.

Aos colegas e amigos do departamento de Saúde Mental da Sociedade de Pediatria de São Paulo, pela fértil interlocução a respeito da importância de contribuirmos na construção de novos olhares sobre a infância e a família.

Aos profissionais e amigos, pela confiança depositada em mim no encaminhamento das participantes do estudo.

À Capes, pelo apoio financeiro que concorreu para a concretização desta pesquisa.

A meus pais, sempre. 
Quando pressentimos, ainda que uma só vez, a imensidão da aventura humana, podemos nos perguntar qual é a força que nos mantém na estreiteza. Andrée Chedid, Visage Premier 


\section{RESUMO}

FOLINO, C. S. G. Sobre dores e amores: caminhos da tristeza materna na elaboração psíquica da parentalidade. 2014. 212 f. Tese (Doutorado) - Instituto de Psicologia, Universidade de São Paulo, São Paulo, 2014.

A gestação e os primeiros tempos da vida de um bebê são fundamentais para o estabelecimento do vínculo com seus pais; além de garantir sua sobrevivência, fornecem matéria-prima para as tramas de seu psiquismo, formando um solo no qual se desenvolverão suas relações ao longo da vida. Concomitante a essa construção, transcorre um processo análogo com os pais, que se vão construindo gradativamente nessa condição ao se relacionar com o filho. No entanto, esses primeiros tempos podem ter um forte impacto em quem gera e cuida do bebê. Assim, a finalidade deste estudo é iluminar as vivências psíquicas da mulher no pós-parto e verificar que recursos desenvolve para lidar com o trabalho psíquico necessário para enfrentar os lutos e construir e exercitar a parentalidade. Por meio de uma pesquisa qualitativa balizada teoricamente pela psicanálise, estudaram-se cinco duplas mãe-bebê. Houve ao menos quatro encontros como cada dupla: pelo menos um na gestação e três após o parto (uma semana, um mês e dois meses). Os encontros gestacionais se deram num lugar escolhido pela participante e os no puerpério, em sua casa. Com o instrumental da psicanálise, fizeram-se entrevistas semidirigidas e observação da relação que a mãe estabelecia com o bebê e com a pesquisadora. Analisou-se cada caso em separado e se verificaram possíveis confluências entre eles. Tendo em conta a especificidade do funcionamento psíquico materno e o impacto das exigências de um filho para quem deve ajudá-lo a viver, a pesquisa revelou a importância de considerar a amplitude dos fenômenos de gestar e cuidar. Esse papel, que toda mãe deve exercer, foi vivido, ao menos num primeiro momento, como brutal e desorganizador não só pela mulher, mas por toda a família. As dificuldades de se metabolizarem essas vivências e as perdas inerentes ao processo - por exemplo, o bebê ideal, a maternidade idealizada, o narcisismo, o ritmo anterior e a rotina, entre outras - podem prejudicar a construção e o exercício da parentalidade e mesmo obstar a superação do baby blues, eventualmente desencadeando fenômenos depressivos (manifestos ou encobertos). Os ganhos reais decorrentes da chegada do bebê podem ser vividos a partir desse contato com as perdas e de sua elaboração. Concluiu-se também que se devem construir mecanismos de prevenção e cuidados para a família nesses primeiros tempos de vida do bebê, com a colaboração entre as várias disciplinas envolvidas e com políticas de saúde pública. Entre as questões levantadas a esse propósito, alerta-se para o risco de se negligenciarem ou, no outro extremo, patologizarem as dores inerentes à delicada construção da parentalidade.

Palavras-chave: depressão pós-parto; baby blues; relação mãe-criança; puerpério; psicanálise. 


\begin{abstract}
FOLINO, C. S. G. On pains and love: paths of maternal sadness on the psychic elaboration of parenthood. 2014. 212 f. Tese (Doutorado) - Instituto de Psicologia, Universidade de São Paulo, São Paulo, 2014.

Gestation and the first times in a baby's life are fundamental to the establishment of bonds with the parents; apart from guaranteeing their survival, it provides the basis for the webs of their psychism, forming the ground on which their relationships will develop throughout their life. Concomitant to this construction, the parents go through an analogue process, gradually building themselves in this condition as they relate to the child. However, these first times may have a strong impact on who generates and cares for the baby. Thus, the aim of this study is to enlighten the woman's postpartum psychic experiences and to verify the resources developed to cope with the psychic work necessary to face the grieves and to build and exercise parenthood. Through a qualitative research theoretically bound by psychoanalysis, five motherbaby pairs were studied. There were a minimum of four encounters with each pair: at least one on gestation e three post-partum (one-week, one-month and two-month old). The gestational meetings took place at a location chose by the participant and the puerperium encounters, at her home. With psychoanalysis instrumental, semiguided interviews and observation of the relationship established by the mother with the baby and with the researcher took place. Each case was separately analyzed and possible confluences between them were verified. Taking into account the specificity of the psychic maternal functioning and the impact of the demands of a child on who must help them live, the research revealed the importance of considering the amplitude of the carrying and caring phenomena. This role, that all mothers must play, was experienced, at least at first, as brutal and disorganizing not only by the woman, but by the whole family. The difficulties of metabolizing these experiences and the losses inherent to the process - for instance, the ideal baby, idealized motherhood, narcissism, the previous rhythm and the routine, among others - may damage the construction and the exercise of parenthood and even thwart the overcoming of the baby blues, eventually unfolding depressive phenomena (manifest or covered). The real gains resulting from the baby's arrival may be lived from this contact with the losses and its elaboration. It was also concluded that prevention and care mechanisms for the family must be built in these first times of the baby's life, with collaboration between the various disciplines involved and with public health policies. Amongst the issues raised to this purpose, an alert is made to the risk of neglecting or, on the other end, pathologizing the pains inherent to the delicate construction of parenthood.
\end{abstract}

Keywords: post-partum depression; baby blues; mother-child relationship; puerperium; psychoanalysis. 


\section{Sumário}

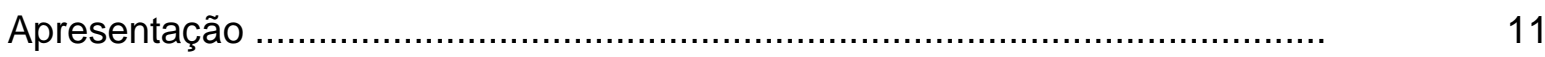

capítulo 1

Esperando uma nova vida: gravidez, maternidade e parentalidade .................. 16

Transgeracionalidade ......................................................................... 25

O nascimento do bebê como trauma para a mãe .......................................... 26

Desejo de ter filho e desejo de ser mãe ................................................... 28

capítulo 2

Os impactos e os destinos do nascimento .....................................................

Depressão ........................................................................................

O trabalho do luto como trabalho de elaboração ........................................... 37

capítulo 3

A respeito do baby blues ...................................................................... 40

Sobre o nome …...................................................................... 40

O que representa esse nome? ............................................................... 40

Um pouco mais de história ...................................................................

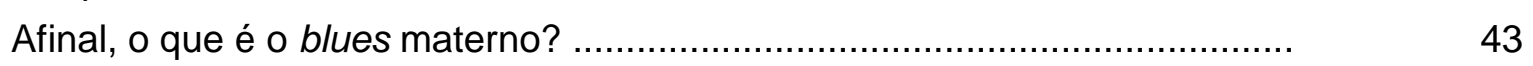

Rastreamento do blues ....................................................................... 46

Tentativas de conhecer ainda mais o blues materno ..................................... 47

O blues materno e os hormônios ............................................................. 49

Pelas tramas do blues materno: o olhar de Myriam Szejer .......................... 50

O olhar de Monique Bydlowski ....................................................................

O olhar de Jacques Dayan e Rozsika Parker ............................................ 55

O olhar de Francis Drossart ...................................................................

O olhar de Joëlle Rochettte ................................................................... 56

capítulo 4

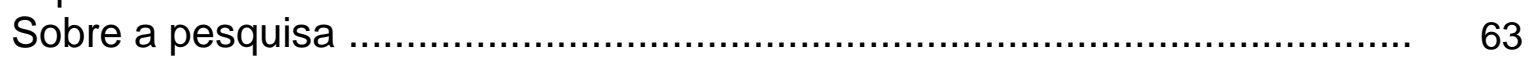

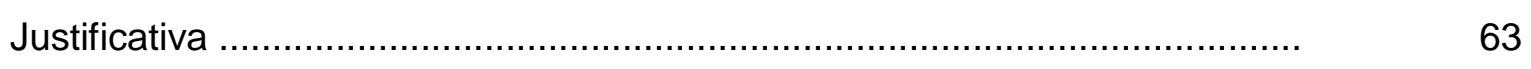

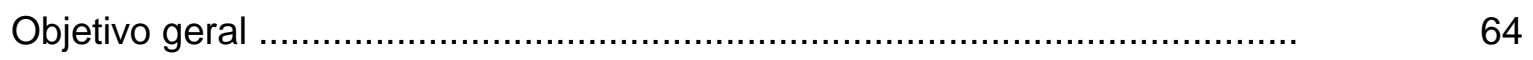

Objetivos específicos .......................................................................

Pesquisa qualitativa e método psicanalítico ................................................. 64

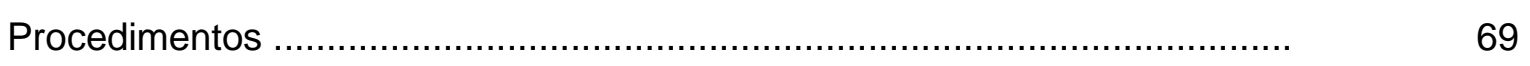

Sujeitos .........................................................................................

Aspectos éticos do projeto e análise de riscos e benefícios .......................... 72

Instrumentos ...................................................................................

capítulo 5

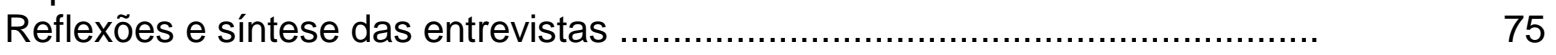

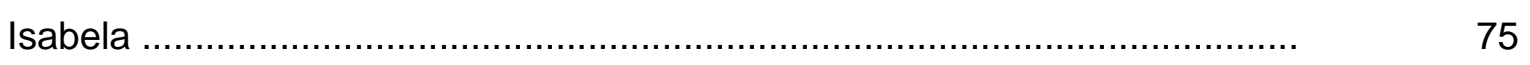

Encontro gestacional ...........................................................................

Primeiro encontro após o parto ........................................................... 83

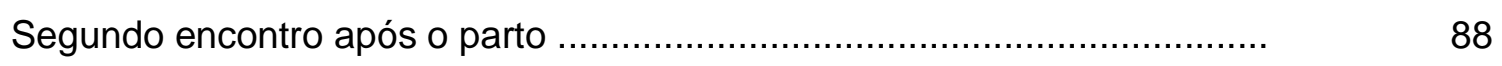




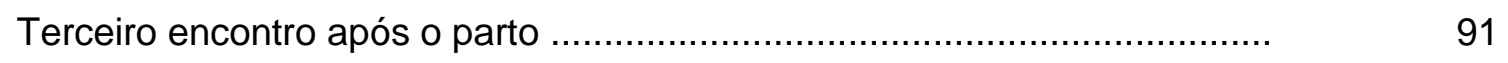

Érika ......................................................................................... 96

Encontro gestacional ..................................................................... 96

Primeiro encontro após o parto ............................................................. 101

Segundo encontro após o parto ........................................................... 106

Terceiro encontro após o parto .......................................................... 109

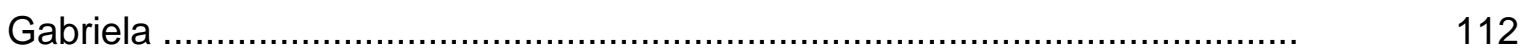

Encontro gestacional ................................................................... 112

Primeiro encontro após o parto ................................................................ 114

Segundo encontro após o parto …....................................................... 117

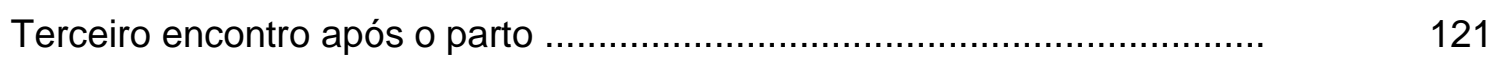

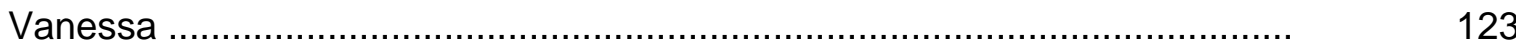

Encontro gestacional ................................................................... 123

Primeiro encontro após o parto ........................................................... 125

Segundo encontro após o parto ............................................................... 129

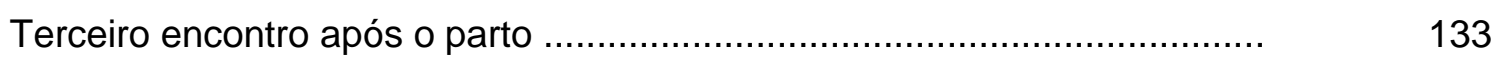

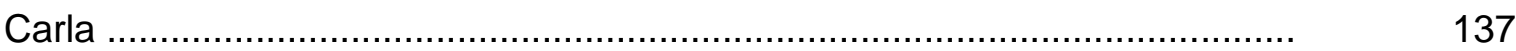

Encontro gestacional .................................................................. 137

Primeiro encontro após o parto ……………......................................... 140

Segundo encontro após o parto ............................................................ 144

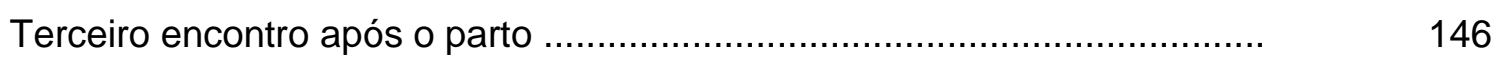

Quadro-resumo: encontro gestacional ....................................................... 150

Quadro-resumo: primeiro encontro após o parto ........................................... 151

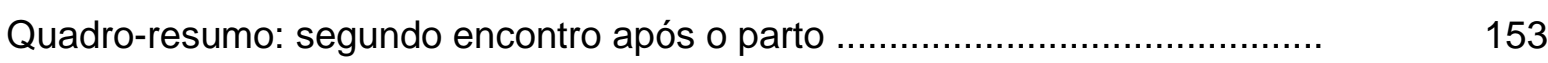

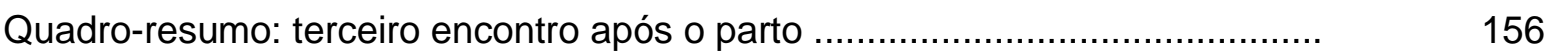

capítulo 6

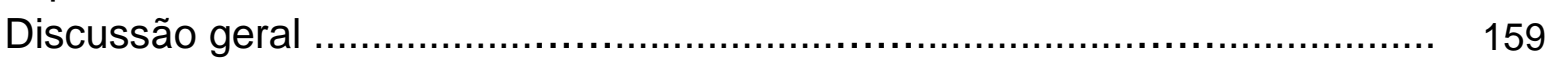

Os caminhos da pesquisa ..................................................................... 159

Aceite do pedido de participação na pesquisa, demanda latente e escassez de mecanismos de suporte social na atualidade ........................................ 160

Encontro gestacional .......................................................................... 164

Primeiro encontro após o parto ............................................................... 170

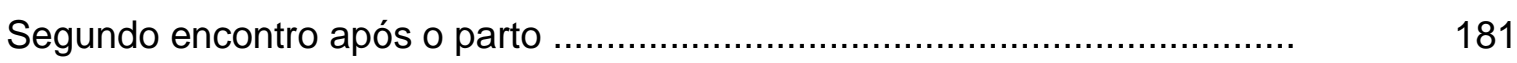

Terceiro encontro após o parto .....................................................................

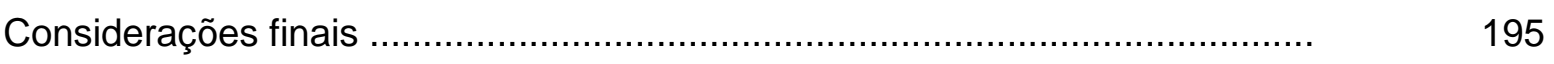

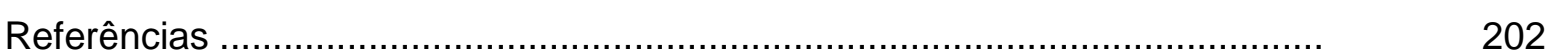

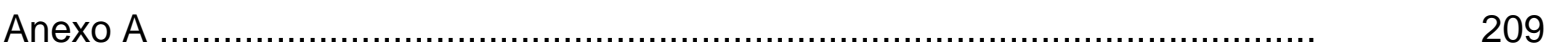

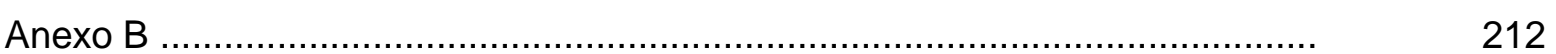




\section{Apresentação}

Eu acreditava que a maternidade simbolizava uma experiência de importância ímpar e parecia ser emblemática do caráter de desenvolvimento psíquico que poderia representar para uma mulher o processo de gestar, dar à luz e cuidar de um filho fruto de um desejo genuíno de ser mãe.

No dia a dia do processo de ajudar o bebê viver e crescer, o fato de ir apresentando e dividindo com ele suas experiências no mundo faria a mulher crescer e se desenvolver, tal como seu filho, e que essa relação seria atravessada por um compartilhamento de prazer.

Inicialmente, empenhei meus esforços no sentido de compreender o que diziam sobre o tema os autores psicanalíticos. Alegrei-me por haver encontrado em alguns aporte teórico para minhas impressões, o que, num primeiro momento, permitiu que eu me aventurasse ainda mais no tema da maternidade e de suas reverberações.

Por outro lado, comecei a deparar autores que, apesar de não negar seus efeitos positivos, introduziam elementos que faziam mais complexa a trama do gestar e do cuidar.

Nesse caminho, algumas questões vieram, de certa forma, complicar o campo, culminando numa inquietação acerca das dificuldades ou impossibilidades de se vivenciar a vinda de um filho e o ser mãe como uma experiência de qualidade eminentemente fértil. Assim, a outra face do fenômeno começou aos poucos a se revelar, até fazer parte das minhas indagações; o que poderia nos ensinar o sofrimento de algumas mulheres que se tornavam mães?

Concomitantemente, fui convidada a integrar a equipe responsável por uma pesquisa que investigaria o impacto da implantação do Método Canguru - um projeto de humanização hospitalar - num hospital público do município de São Paulo (Feliciano et al., 2007). 
Acompanhando essas mulheres, entendi o que pode ser para os pais a outra face da vinda de um filho. Defrontei-me com a angústia causada pelo risco que correm os bebês nascidos prematuramente, constatando a dor e o sofrimento das mães que temiam pela vida de seu bebê e a dificuldade de muitas de se apropriar de seu filho e ajudá-lo a superar suas dificuldades iniciais.

Por outro lado, essa experiência revelou a importância do acolhimento das angústias maternas no período perinatal e como ela pôde ajudar as mães a voltarem a se vincular com seu bebê, oferecendo-lhes um colo psíquico, fundamental nesses primeiros tempos.

Constatei os efeitos que algumas informações médicas tinham sobre as mães, muitas vezes transtornando-as ainda mais e repercutindo na relação que estabeleciam com o filho - e me perguntava se os profissionais eram conscientes dessa situação. Nesse trabalho, percebi que, para além dos efeitos na dupla mãe-bebê, a escuta psicanalítica podia ser um instrumento valioso para a equipe de saúde, visando a melhoria dos cuidados da família.

Meu percurso na literatura apontava a compreensão de que, a partir da gestação, a mulher vivia estados psíquicos sensíveis, pela necessidade de se vincular e conectar ao bebê nos primeiros tempos de vida. Ficava sujeita à regressão psíquica e à identificação tanto com o bebê quanto com sua própria mãe, especialmente em seu papel materno. Além disso, os conteúdos inconscientes ficavam mais acessíveis, devido a um afrouxamento da repressão que normalmente impede seu acesso à consciência.

Compreender esses estados foi essencial para eu pensar que, além de poder ser um período muito rico para a mulher, a gestação seria também motivo de dificuldades, justamente pela particularidade de seu psiquismo nesse período.

O tema me intrigava cada vez mais e me impelia a investigar as dificuldades maternas após o nascimento do bebê, para entender como elas transcorriam e qual seria sua importância na relação entre eles. Foi assim que surgiu a necessidade de pesquisar a depressão pós-parto, por seus efeitos na relação mãe-bebê. 
Isso me levou a estudar, no mestrado (Folino, 2008), o diagnóstico da depressão puerperal. Considerando-os os profissionais mais próximos da família no início da vida do bebê, entrevistei pediatras e, a partir de seus depoimentos, identifiquei os elementos de que dispunham e como os utilizavam para diagnosticar depressão materna.

Obtive elementos fundamentais da ótica desses profissionais sobre as mães de que tratam e do que mais Ihes chama atenção no cuidado com seus bebês. Paralelamente, observei que alguns dos pediatras entrevistados tinham já algum conhecimento psicanalítico, o que me levou a constatar a marcante contribuição da psicanálise, permitindo-Ihes uma atitude clínica de qualidade diferenciada, pela integração de pontos privilegiados pela teoria e pelas práticas analíticas a seus conhecimentos em pediatria.

Os achados da pesquisa indicaram que grande parte dos médicos que se mostraram mais sensíveis ao contato com a mãe e o bebê, valorizando o aspecto primordial dessa relação, se beneficiou, em algum momento de sua prática clínica, dos subsídios oferecidos pela psicanálise. Introduzir na consulta pediátrica um olhar sobre a relação da mãe com seu bebê permeado pela contribuição psicanalítica se mostrou muito útil para a avaliação e o diagnóstico da depressão pós-parto.

Por outro lado, alguns pediatras apresentaram grande dificuldade para diagnosticar o fenômeno, uma vez que pareciam estar impossibilitados de considerar o aspecto psíquico da experiência mãe-bebê, o que se refletia numa incapacidade de entender as filigranas da relação primordial e do estado sensível em que a mulher encontra-se no pós-parto. Só cogitavam a possibilidade de uma mãe estar deprimida quando ela chorava diante deles, durante a consulta pediátrica. Analogamente, penso que isso se aproximava da minha crença anterior, de que o nascimento e o tornar-se mãe tinham apenas aspectos positivos, e acentuo esse ponto porque me parece pertinente esclarecer que uma possibilidade de ampliarmos nosso olhar e subsidiar outros profissionais para essas questões exige um certo trabalho, talvez como aconteceu comigo a respeito de minha antiga crença, uma vez que uma abertura de um campo, seja de conhecimento ou de experiências, não está dada a priori. 
Para além da dificuldade específica de alguns pediatras, o estudo apontou uma dificuldade geral de detectar e diagnosticar a depressão que ocorre no pós-parto em virtude de algumas questões. Em linhas gerais, por uma formação insuficiente para uma visão mais abrangente dos elementos em jogo na perinatalidade, bem como para uma das características da depressão puerperal: a de ser fugidia e confundir-se com um quadro comum após o nascimento, nomeado na literatura como baby blues, ou sentimento de tristeza decorrente das intensas mudanças na vida da mulher, ao lado das oscilações hormonais que acompanham esse período.

Compreendi que, em alguns casos, a linha entre a sensibilidade normal característica do baby-blues e o estado de depressão propriamente dito é bastante tênue. Também é difícil diferenciar a depressão materna com característica ansiosa e o estado normal da mãe, uma vez que não se extinguem nela os cuidados com o bebê. Outra questão importante é a dificuldade de toda a família distinguir um prolongamento do estado frágil da mulher de outro quadro mais preocupante, que demanda cuidados interventivos, o que, em alguns casos, gera um clima familiar de insegurança em relação à puérpera.

Outra contribuição fundamental dos pediatras mais bem instrumentalizados é o fato de estarem muito sensíveis para perceber sinais de que algo não vai bem com a dupla mãe-bebê, pois, exceto por uma manifestação velada, a depressão puerperal não surge frequentemente como queixa manifesta nos consultórios pediátricos.

Neste ponto, importa dizer que, em alguns casos, a depressão que acomete a mulher se mostra num quadro mais definido e mais facilmente detectável pelos profissionais e por todos, mas, mesmo assim, os achados da pesquisa evidenciaram uma ocorrência bastante reduzida de diagnósticos.

Uma contribuição interessante de alguns médicos mais sensíveis despertou-me um grande interesse: lembraram que o baby blues pode gerar angústia e sofrimento na mulher num momento em que ninguém - nem ela - esperam nada próximo desse estado. 
Os achados da pesquisa levaram a pensar na importância de se conhecerem melhor os dois estados, para favorecer a detecção de distúrbios mais sérios.

Primeiramente, eu acreditava que deveria me concentrar na investigação de uma espécie de discriminação mais fina de um estado de entristecimento que pode se transformar num quadro depressivo mais sério, com efeitos potencialmente deletérios, se não for diagnosticado e tratado a tempo. No entanto, ao longo da pesquisa, o próprio baby blues se revelou um solo fecundo das vivências psíquicas do puerpério, aproximando-me, ao mesmo tempo, do ponto inicial, sobre a depressão puerperal.

Estas constatações reverberaram profundamente no meu olhar para os fenômenos envolvidos no gestar e no cuidar e me impulsionaram a compreender melhor os aspectos envolvidos no baby blues, por eu acreditar que ele seria uma espécie de chave para a compreensão dos estados depressivos no pós-parto. É a partir dessa hipótese que esta tese reúne elementos para se fundamentar e se construir, tentando ultrapassar as estreitezas que a vida nos impõe.

Assim, este trabalho se propõe investigar mais de perto os fenômenos psíquicos do período puerperal, no qual normalmente se encontra o baby blues.

Partimos da hipótese de que o nascimento de um bebê é um processo que inclui muitos ganhos e muitas perdas - nem sempre consideradas na gestação, em virtude de uma certa dose de idealização, necessária para forjar um lugar para o bebê no psiquismo dos pais.

$\mathrm{Na}$ observação das duplas mãe-bebê que participaram deste estudo, procuramos observar os caminhos da tristeza materna e como cada mulher reagiu à vinda do filho. 


\section{capítulo 1}

\section{Esperando uma nova vida: gravidez, maternidade e parentalidade}

Antes de nos determos mais especificamente nos lutos que envolvem a construção da parentalidade e que podem figurar como pano de fundo nas depressões pós-parto ou nos baby blues, discutiremos os acontecimentos físicos e psíquicos da gestação.

A gestação não só gera um novo ser e modifica fisicamente os órgãos e os contornos da mulher, como pode ser entendida como um modo de prepará-la psiquicamente para a complexa tarefa de se tornar mãe.

O que acontece com a mulher quando ela engravida? Que alterações sofrem seu corpo e seu psiquismo?

Do ponto de vista físico, a gravidez é um processo extremamente complexo, envolvendo a síntese de vários hormônios em momentos específicos.

Desde a concepção, para se unir, um espermatozoide e um óvulo devem vencer inúmeros obstáculos e enfrentar uma árdua jornada, que pode também malograr. Quando todo esse caminho se dá a contento e o encontro entre óvulo e espermatozoide logra êxito, cria-se a matriz de uma única célula que contém toda a informação genética dos dois parceiros.

A concepção depende da sincronia entre um óvulo maduro pronto da mulher e um espermatozoide sadio do homem que chegue à tuba uterina. A vida útil dos espermatozoides dentro do corpo da mulher é, em média, de quatro dias; depois disso, eles morrem e não são mais capazes de fertilizar um óvulo. Alguns espermatozoides podem chegar à camada externa do óvulo, outros podem atravessar uma segunda camada, mas normalmente apenas um é capaz de chegar ao núcleo e fundir-se a ele, formando-se imediatamente uma barreira química a seu redor, para impedir a entrada de qualquer outro espermatozoide.

Após a fusão, o espermatozoide perde a cauda e sua cabeça aumenta; no interior da célula, mesclam-se os cromossomos de uma única célula com 46 cromossomos de informação genética, sendo 23 de cada um dos genitores, e, em 
algumas horas, depois da divisão, haverá duas células, junto com a replicação do ácido desoxirribonucleico, o DNA. A rápida divisão será concomitante ao caminho que segue até o útero onde se implantará e se desenvolverá o feto, se tudo ocorrer bem (Taborda; Deutsch, 2004).

Após a concepção, a mulher passa por profundas mudanças corporais: seu corpo se ajusta à nova tarefa de formar e alimentar um bebê. Tais mudanças são tanto externas quanto internas: ganho de peso, seios mais volumosos, alterações nos cabelos e na pele, entre outras. As internas tangem à multiplicação de vários hormônios que já existem, bem como à produção de novos, próprios da gestação, como é o caso da gonadotrofina coriônica humana (HCG); também conhecida como "hormônio da gestação", é ela que aparece no exame de sangue que confirma a gravidez. Essa substância é a responsável por preservar a gestação e evitar que a mulher menstrue, mas também concorre para os enjoos matinais. Outros hormônios envolvidos são a progesterona, que tem uma importante função na preservação da gravidez, o estrogênio, a somatotrofina coriônica humana, a calcitonina, a tiroxina (T3 e T4), a relaxina, a insulina, a ocitocina, a eritropoietina, o cortisol e a prolactina. A gestante sofre ainda alterações na circulação, na pressão arterial, na respiração e no metabolismo (Taborda; Deutsch, 2004).

$\mathrm{Na}$ literatura médica, alguns autores descrevem essas alterações hormonais e fisiológicas como "tsunamis" no corpo feminino, e essa metáfora parece ser emblemática do que se passa física e psiquicamente com uma mulher que engravida. A gestação engendra uma verdadeira revolução do ponto de vista orgânico, bem como do ainda muitas vezes negligenciado e mesmo desconhecido ponto de vista psíquico. Ao gestar um bebê, a mulher também deve forjar um espaço psíquico para seu filho e se preparar para construção em seu psiquismo um lugar para si como mãe e para seu companheiro como pai desse bebê. Assim, a gravidez enseja diversos níveis de experiência, e o que ocorre no corpo é só uma parte do que ocorre em todo o ser de uma gestante.

Ao gerar um bebê, não só o corpo da mulher se transforma como todo seu psiquismo passa a se preparar para constituir outro ser e também para se reconstituir em função de seu papel materno. Apesar de se poder entender essa etapa como preparatória para a maternidade, não há garantias de que uma gravidez 
bem vivida engendre todas as condições de um puerpério igualmente tranquilo. Este parece depender muito das condições de a mulher fazer um deslizamento entre seu narcisismo inicial - posto à prova novamente $\mathrm{e}$, depois do parto, flagrantemente - $\mathrm{e}$ sua capacidade de ver um bebê como um outro diferente de si mesma.

Autores como Daniel Stern e Nadia Bruschweiller-Stern (1998), Joan Raphaell-Leff (1997) e Monique Bydlowski (2002) discutem a experiência interior de tornar-se mãe e a esfera psíquica da gestação e da maternidade, algo que é tratado no meio médico e em nossa cultura como natural, inerente à vida da mulher, e com uma forte carga de idealização.

A maternidade é fruto de um intenso trabalho que cada mulher realiza de forma singular e que resulta num psiquismo materno, reflexo de uma experiência íntima e profunda. O nascimento psicológico de uma mãe pode demorar mais tempo e atravessa algumas fases para além do parto em si. A organização psíquica da maternidade só toma forma a partir da experiência contínua de cuidar e alimentar o bebê (Stern; Bruschweiller-Stern,1998).

Szejer (2002) discute o fato de que o discurso social sobre a mulher grávida é idealizante, idealizador e redutor, criando um viés do que deveria ser uma compreensão mais ampliada do fenômeno da gestação e, acreditamos, da maternidade como um todo. Segundo a autora:

Ao idealizar-se a imagem da gravidez bem-sucedida, banaliza-se 0 fenômeno e não se toma em conta a violenta experiência vivida: prazerosa ou dramática, angustiante ou cheia de entusiasmo. Para a mulher grávida, é um período de transição, de metamorfose, de iniciação (Szejer, 2002, p. 195).

Pressionada por uma sociedade que glorifica a maternidade - negando, assim, sua ambivalência -, a mulher é compelida a ocultar a todo custo os sentimentos negativos referentes à experiência de ter um filho (Raphael-Leff, 1997). Mesmo tratando-se de um filho, a ambivalência que subjaz à presença desse outro em seu corpo e em seu mundo psíquico não pode ser significada de modo a obrigar a mulher a fazer uma separação radical entre aquilo que experimenta e aquilo que pode dizer e mostrar às outras pessoas e a si própria. 
A idealização da gravidez, da maternidade e das crianças em nossa cultura obsta a escuta dos fenômenos que envolvem o gestar e o maternar por uma visão extremamente parcial e frequentemente cega. Entendida por Laplanche e Pontalis (1986) como o processo psíquico pelo qual as qualidades e o valor dos objetos são considerados perfeitos, a idealização impede questionarmos, estudarmos ou escutarmos algo da ordem da perfeição. $O$ adjetivo perfeito não admite nenhuma ordem de questão nem qualquer rastro de dúvida, ambiguidade ou sofrimento.

As definições e os sinônimos encontrados em Houaiss (Grande [...], 2012) para as palavras perfeito e perfeição podem iluminar essas questões:

perfeito. Em que não há defeito; que apresenta as melhores qualidades.

perfeição. Que se caracteriza por ser completo; cabal, rematado, total; que se destaca por ser notável, magistral; o mais alto nível numa escala de valores; excelência no mais alto grau; pessoa ou coisa perfeita.

Considerar perfeito gestar e ter um filho impede que os ouvidos e o coração aceitem que, como todas as demais, essa experiência humana também envolve ambiguidades, ambivalências e dúvidas e, implicando um não saber, deve ser vivida para ser conhecida de fato. Em particular, ela não só é imperfeita como é altamente complexa para quem a atravessa e para quem está próximo; o próprio pai do bebê pode viver um fenômeno análogo, revisitando, de certa forma, sua infância e seu papel de filho. Acresce-se que os profissionais da saúde que atendem a mulher e a família também são envolvidos por esse discurso, uma vez que nossa pesquisa anterior verificou que seu olhar e sua escuta parecem atravessados e reduzidos a essa idealização da gestação e da maternidade, o que leva à constatação da deficiência da formação desses profissionais (Folino, 2008).

Para além da idealização, devemos realçar o caráter de encantamento presente nessa experiência de gerar e concorrer para a constituição de um novo ser que nos sucede na cadeia geracional, tornando-nos um elo conectivo entre gerações. Na medida em que o encontro entre um óvulo e um espermatozoide pode engendrar a criação e o destino de um ser humano diferente dos progenitores - mas intrinsecamente ligado a ambos e à história individual de cada um e, em última instância, à história ou à precariedade de sua história como casal -, há aí algo 
mágico e surpreendente. Além disso, a potencialidade da vida e seu vigor podem ser deflagrados nessa experiência de gerar e cuidar de um fruto do próprio ventre.

Gerar e transmitir a vida podem ser representados como um bem maior, como resultado de uma força vibrante da natureza, principalmente se tudo caminha sem tantas intercorrências e se o filho chega no momento do desejo na esfera mais consciente dos pais.

Segundo Debray (1988), o caminho que vai do projeto de filho ao filho real pode ser considerado um percurso semeado de emboscadas:

Tornar-se mãe e pai reaviva necessariamente, em todo indivíduo
humano, desejos antigos experimentados na infância em face de
seus próprios pais, vividos então como adultos todo-poderosos.
Foram eles que, naquele tempo decidiram nosso nascimento, bem
como o de nossos eventuais irmãos, suscitando ao mesmo tempo
nossa inveja e nosso ódio. Mas, durante a infância, não há outra
solução senão esperar uma maturidade suficiente para ser capaz de
procriar por si mesmo, e durante essa espera muitos elementos de
natureza muito variada podem intervir para modificar de maneira
amiúde contraditória o que podia ser originalmente um desejo de ter
um filho. É dizer que esse desejo que se atualiza num momento da
vida por um projeto de filho é ele mesmo, necessariamente,
contraditório e profundamente ambivalente (Debray, 1988, p. 15).

Tornando-nos pais, tomamos nosso lugar na cadeia geracional, o que implica que aceitemos o caráter finito da vida; ao mesmo tempo em que nos tornamos pais, atingimos um acesso à maturidade, o que pode anunciar simultaneamente nosso desaparecimento, nossa morte (Debray, 1988).

Percebemos, assim, como esse tema é intrincado e pode resvalar em várias questões. Não devemos perder de vista que, a cada novo nascimento, há na mulher uma multiplicidade de impressões, angústias, sensações e vivências e que um olhar apressado pode não favorecer a emergência, a compreensão e a contenção do fenômeno.

A gravidez é uma experiência extremamente complexa, propiciadora e mobilizadora de profundas angústias. Leva a uma verdadeira revolução dos papéis desempenhados pela mulher até então e é também profundamente afetada por mudanças sociais. Atualmente, na grande maioria das vezes, a mulher precisa 
conciliar uma vida profissional intensamente investida com o desejo de ter um filho, questão que está longe de ser simples e sem conflitos decorrentes.

Vários autores se dedicaram a estudar a especificidade do psiquismo materno no ciclo gravídico puerperal, por ângulos diversos, complementares ou díspares. Sabemos que a mulher que engravida regride a etapas anteriores de seu desenvolvimento psíquico, identificando-se com sua mãe, em suas tarefas maternas, e com o bebê que carrega no ventre, por se sensibilizar com suas necessidades (Langer, 1986). Para Brazelton e Cramer (1992), essa dupla forma de identificação é especifica da maternidade: a mulher desempenha e elabora papéis e atributos da mãe e do bebê, baseando-se na convivência que teve com a própria mãe quando era bebê.

Winnicott (2000a) destaca o fato de - ao longo e sobretudo no final da gestação, perdurando às vezes até os primeiros dias do bebê - a mulher desenvolver um estado psicológico especial chamado preocupação materna primária. Considerado uma sensibilidade exacerbada, esse estado seria uma doença se não houvesse uma gestação em curso e faz com que a mulher seja capaz de se identificar intimamente com seu bebê e oferecer-lhe aquilo de que necessita na hora propícia.

A preocupação materna primária pode ser considerada um estado de retraimento ou até de dissociação; espera-se que a mãe seja capaz de atingi-lo e de recuperar-se dele quando essa ligação mais intima com o bebê não for mais estritamente necessária. A regressão e a identificação são dois aspectos do exercício da maternidade no início da vida do bebê.

Para Brazelton e Cramer (1992), a gravidez é reflexo de toda a vida da mulher anterior à concepção, e o ressurgimento da relação com sua própria mãe é um processo que se desenvolve com forte intensidade.

Por outro ângulo, Françoise Dolto (1996) chama a regressão característica desse período uma "armadilha da maternidade real", pois, no cotidiano da gravidez, as angústias decorrentes da experiência do parto e, após a criança nascida, a amamentação e as necessidades regulares que um bebê impõe podem motivar a 
completa regressão da mulher ao papel de mãe, afastando-a de seu lugar de mulher.

Segundo Monique Bydlowski (2002), a vida psíquica das mulheres durante a gravidez muda naturalmente; a partir da pesquisa clínica com gestantes, ela postula:

[...] a gravidez é o momento de um estado particular do psiquismo, estado de transparência em que os fragmentos do pré-consciente e do inconsciente chegam facilmente à consciência. Esse fenômeno, que clinicamente caracteriza com frequência graves afecções, apresenta-se na gestante como um acontecimento normal (Bydlowski, 2002, p. 205).

O processo consiste no levantamento da repressão da gestante, deixando emergir conteúdos e conflitos inconscientes que normalmente não são acessíveis à consciência. Esse contato relativo com tais conteúdos emersos de um psiquismo em transparência pode, por si só, deflagrar estados extremamente sensíveis nesse momento delicado da vida da mulher.

Bydlowski (2002) não é a primeira a postular o aspecto de crise psíquica que a gravidez representa; semelhante à crise da adolescência, é um período repleto de conflitos e considerado uma crise maturativa, porque, na ocasião do nascimento do primeiro filho, opera-se uma mudança de geração, que é irreversível e que mobiliza um excesso de energia psíquica que exige do psiquismo um trabalho complexo.

Joan Raphael-Leff (1997) salienta que autoras psicanalíticas como Helene Deutsch (1944), Grete Bibring (1959), Judith Kestenberg (1976) e Dinora Pines $(1972)^{1}$ já haviam observado na mulher grávida, concomitante ao fortalecimento da consciência das sensações corporais, a agitação e a revitalização de antigas ansiedades e emoções antes adormecidas.

Simultaneamente ao nascimento de um bebê, espera-se que nasça uma mãe, mas, na verdade, o que acontece é um aparecimento progressivo ao longo da gestação. Nessa perspectiva, o tempo da gravidez pode ser entendido como propício para haver, concomitantemente ao crescimento do bebê no ventre materno,

\footnotetext{
${ }^{1}$ BIBRING, G. Some considerations of the psychological processes in pregnancy. Psychoanalytic Study of the Child, v. 16, n. 9, 1959; DEUTSCH, H. The Psychology of Women: a psychoanalytic interpretation. New York: Grune \& Stratton, 1944; KESTENBERG, J. Regression and reintegration in pregnancy. Journal of the American Psychoanalytical Association, n. 24, p. 213-250, 1976.
} 
a constituição de uma mãe para esse bebê. Assim, é preciso construir um espaço psíquico para a criança, ao mesmo tempo em que se vai construindo um papel materno. Por isso, o tempo da gravidez é sumamente importante, tanto para o bebê quanto para a mãe e para o pai, que acompanhará externamente as mudanças que se vão operando em sua parceira. As transformações físicas que se verificam na gravidez prenunciam outras, mais drásticas, que sobrevirão ao nascimento do bebê. Já na gestação, sua mulher deixará de ser apenas mulher e passará a ser também mãe, o que pode provocar certa distância do companheiro. Além disso, em casos de mulheres multíparas, há ainda a importância de o filho mais velho ir construindo a ideia que não será mais o único.

De acordo com Bydlowski (2007), antes de nascer, a criança é preponderantemente imaginária, e se supõe que ela deve cumprir, reparar e preencher tudo: lutos, saudades, destinos e sentimentos de perda. A autora lança a hipótese de que o que normalmente se deseja não é tanto a criança concreta, mas a realização do mais infantil dos desejos: o desejo nostálgico de encontrar-se a si mesma como o bebê vulnerável dos primeiros meses de vida.

Em 1914, Freud (2010a) já apontava o fato de que o investimento dos pais no bebê provém da revivescência e da reprodução do narcisismo abandonado por eles e que será revivido na relação com o filho. A partir do narcisismo parental, os pais poderão investir libidinalmente o filho; nessa perspectiva, desejar um filho é renascer no corpo desse bebê, perpetuar-se e transmitir a vida, mas, em contrapartida, é também admitir a finitude da vida. Ao ter um filho, nos deparamos com a morte; assim, nascimento e morte são as duas faces da mesma moeda - o começo remete ao fim, e eles parecem se retroalimentar: "No ponto mais delicado do sistema narcísico, a imortalidade do Eu, tão duramente acossada pela realidade, a segurança é obtida refugiando-se na criança" (Freud, 2010a, p. 37).

Por outro lado, vários autores ressaltam o lugar e a importância da construção mental do bebê imaginário naquela que gesta. Por exemplo, Winnicott (2000a) acentua a necessidade da mãe de se identificar progressivamente com seu bebê, ao mesmo tempo em que vai construindo um espaço psíquico para ele. Os meses de gestação são uma oportunidade de preparação psicológica para os pais, e não apenas corporal (Brazelton; Cramer, 1992). Esse tempo é fundamental para a 
construção da representação do bebê no imaginário materno: "[...] a importância do tempo, da previsão da duração da gravidez, internalizada pela mãe, e que vai marcando para ela o processo de crescimento do bebê dentro de si" (Aragão, 2011, p. 36).

A gestação deve ser considerada a partir de dois vértices: o biológico e o referente à relação de objeto, o qual foi tangenciado no início deste capítulo - como uma única célula vem a constituir, por um longo processo, um ser humano, e, concomitantemente, instala-se uma relação de objeto que é representada por um "corpo imaginado", que acompanhe e precede a criança de fato. Para Piera Aulagnier (1990), esse "corpo imaginado" é um corpo unificado e completo no qual a libido materna passa a ser despejada. Assim, uma história e uma imagem de um corpo precedem o bebê em sua chegada ao mundo:

[...] [este] "Eu [Je] antecipado" traz consigo a imagem desta criança que ainda não está ali, imagem fiel às ilusões narcísicas da mãe e imagem mais chegada de uma criança ideal [...]. A experiência clínica nos dá prova do quão frágil pode se revelar todo aparente equilíbrio psíquico frente a certas provas: sublinhei frequentemente tudo o que a experiência da gravidez comporta de único e porque, para certas mulheres, ela pode representar uma prova psiquicamente perigosa, pelo fato de que ela vai reativar e remobilizar todo um passado relacional mais ou menos ultrapassado, que elas deverão reviver sob forma inversa (Aulagnier, 1999, p. 38/39).

A autora destaca ainda a vulnerabilidade psíquica da gravidez e a criança das ilusões narcísicas; o bebê imaginário precisa ser investido durante a gestação para o posterior afastamento da mãe, que então deve proceder ao investimento do bebê real. Parece ser esse o jogo deflagrado pelo parto: no momento em que nasce o bebê real, seu representante imaginário, fruto do narcisismo dos pais, precisa ir perdendo gradativamente a força pelo desinvestimento materno, cedendo lugar à "criança das relações de objeto" - que passam a transcorrer com o bebê de carne e osso que agora nasce.

No entanto, importa considerar que não existem linhas demarcatórias tão claras entre o "bebê de dentro" e o "bebê de fora"; prova é que, na gestação, esperase que a mãe se possa relacionar com o bebê, antecipando-o. Ao ser antecipada, a criança pode ser pensada pela mãe, o que pode vir a indicar um investimento da criança como outro, e não como prolongamento materno. 
Segundo Sylvain Missonier (2004), em termos de antecipação da criança ocorrida no decorrer da gravidez, a mudança no discurso dos pais do dois (casal) para o três (mãe, pai e bebê) pode ser um indicativo importante da qualidade de seu acolhimento à criança. Especialmente entre o quinto e o fim do sétimo mês, a gestante sente os movimentos do feto em seu ventre, o que pode favorecer o incremento do apego primordial, bem como o fenômeno da antecipação.

Esses movimentos são a primeira contribuição da criança ao relacionamento com os pais, dando sinais de que é um ser separado, o que possibilita o incremento de sua relação com eles (Brazelton; Cramer,1992).

Claro está que as nuances do narcisismo parental matizarão o psiquismo, o corpo e as relações com o filho que chega. Silvia Bleichmar (1994) propõe qualificar o narcisismo materno como "transvasante", porquanto, sem se esgotar na mãe, ele "transvasa" para o filho; alimentando-o com seu próprio narcisismo, a mãe possibilita a alternância geracional.

\section{Transgeracionalidade}

Convergindo para um ponto fundamental da questão geracional, está o tema da transmissão inter e transgeracional. A transmissão psíquica pode ser intergeracional, relativa à transmissão de pais para filhos, e transgeracional, de avós para netos. Ela é particularmente importante nos casos de transmissão de conflitos inconscientes e pode acontecer por meio do que Lebovici, Solis-Ponton e Barriguette (2004) chamaram de "mandato transgeracional", eventualmente bloqueando o desenvolvimento do bebê. Os autores consideram esses dois tipos de transmissão a herança psíquica do ser humano.

Procurando compreender de outra forma o significado dos termos transmitir e transmissão, recorremos a sua etimologia; derivadas do latim, significam, respectivamente, "enviar de um lugar para outro, transportar, transferir", "ser condutor de, propagar ou ser propagado, transportar(-se)" e "passagem de um lugar para outro, trajeto" (Grande [...], 2012). 
Seja inter ou transgeracional, a transmissão psíquica enseja modos de passagem de um lugar (psiquismo materno, paterno e psiquismo das gerações anteriores) para o bebê que nasce, para compor-se com seu psiquismo. É um meio de propagação das histórias e também dos conflitos de uma geração a outra.

A gravidez pode ser considerada uma preparação para o ser mãe, mas o evento disruptivo que o parto pode representar parece não garantir em todos os termos que o exercício da maternidade se dê sem uma dose de desestabilização, disparada pela saída do bebê do ventre materno. Além da mudança devido à regressão no funcionamento psíquico da mãe, iniciada na gestação, há após o parto uma verdadeira revolução, com a emergência de uma nova demanda de trabalho psíquico para a mulher.

\section{O nascimento do bebê como trauma para a mãe}

Régine Prat (2008, p. 127) comenta que, com "a chegada de um bebê, a mãe perde sua identidade e deverá constituir uma nova, troca de pele". E complementa citando Jeanne Magagna:

Ela não é mais a mulher adulta capaz [...] não sabe quem ela é, porque ainda não adquiriu sua nova identidade de mãe. Sua confusão e o sentimento muito doloroso de perda de sua identidade se somam à tomada de consciência de sua total responsabilidade em relação ao bebê (Magagna, $1992^{2}$ apud Prat, 2008, p. 127).

O encontro com o bebê propõe à mãe uma experiência única, traumática, em certo sentido, que demanda um remanejamento total (e imediato) de todo o seu funcionamento psíquico (Prat, 2008).

A autora acredita que, para a mãe, o impacto do nascimento de um filho está relacionado à descoberta da dependência absoluta do bebê em relação a ela: "Essa descoberta da dependência é brutal; não há gradação, aprendizagem, evolução. No momento da chegada do bebê, o mundo da mãe estremece: ela se torna a pessoa da qual o bebê é totalmente dependente" (Prat, 2008, p. 128).

\footnotetext{
${ }^{2}$ MAGNANA, J. Observation d'un bébé avec Esther Bick. Jounal de Psychanalyse de l'Enfant, Bayard Ed., n. 12, p. 173-208.
} 
A mãe toma contato com essa nova realidade em aspectos muito concretos da vida com seu filho, na satisfação de suas necessidades vitais. No entanto, descobre que isso é apenas parte de um todo muito maior; além disso, há a absoluta dependência psíquica do bebê em relação a ela - ele depende de seus cuidados para se constituir psiquicamente.

A combinação desses dois fatores - dependência física e psíquica - cria uma situação completamente nova e singular:

[...] poder assumir esse papel supõe uma mutação profunda do psiquismo parental, que a partir dessas experiências se tornará radicalmente diferente do que era antes e, consequentemente, diferente daqueles que não são pais (Prat, 2008, p. 128).

Assim, pode-se compreender o possível caráter traumático do nascimento para os pais, especialmente para a mãe, devido às intensas transformações a que fica sujeita, não só físicas - com o advento da gravidez e, depois, com o da "barriga murcha" que muitas vezes o puerpério representa -, mas também psíquicas, caracterizando-se uma crise psíquica, com uma mudança radical de posição sem equivalentes no percurso da vida de uma pessoa.

Podemos compreender que, com a presença do bebê real no cenário materno, deflagrada no parto, que parece ser um divisor de águas, a mulher pode ter uma experiência traumática. Ela deve elaborar várias perdas, mas, fundamentalmente tem que lidar com uma espécie de "perda de si mesma"; perdendo-se parte de sua identidade anterior, exige-se um intenso trabalho do psiquismo. Laplanche e Pontalis (1986, p. 678) nos ajudam a pensar no trauma como um:

Acontecimento da vida do indivíduo que se define pela sua
intensidade, pela incapacidade em que se acha o indivíduo de lhe
responder de forma adequada, pelo transtorno e pelos efeitos
patogênicos duradouros que provoca na organização psíquica. Em
termos econômicos, o traumatismo caracteriza-se por um afluxo de
excitações que é excessivo, relativamente à tolerância do indivíduo e
à sua capacidade de dominar e de elaborar psiquicamente essas
excitações.

A mulher deve lidar com um certo excesso. Já assoberbado com a regressão peculiar desse período e as decorrentes transparência psíquica e preocupação materna primária, o psiquismo sofre um impacto. O trauma característico do 
nascimento de um filho experimentado no puerpério reverbera intimamente em como a mulher consegue dar um destino a esse impacto - trata-se de se organizar da maneira que for capaz.

\section{Desejo de ter filho e desejo de ser mãe}

Outra questão pertinente é diferenciar o desejo de ter filhos do desejo de ser mãe. Uma leitura apressada pode levar a um certo engodo, pois, embora possa parecer que lidamos com o mesmo desejo, quando nos aproximarmos, somos confrontados com algo diverso. A gestação e a maternidade são processos que se sucedem, mas não são o mesmo. Segundo Maria Elisa Pessoa Labaki (2008), distinguem-se quanto ao tempo em que se processam e à natureza de cada um; não há continuidade entre a gravidez e o exercício da maternidade, mas uma ruptura que se opera com o nascimento do bebê.

A maternidade parece acontecer no registro diverso do narcísico, pois pede uma força contrária, de desprendimento de si e de perda narcísica, ao mesmo tempo em que ocorre investimento no objeto-filho (Labaki, 2008). Assim, é preciso perder para tornar-se mãe.

Há aí uma tensão entre duas forças que se põem lado a lado, são vizinhas, mas não são - nem representam - a mesma coisa: o desejo de ter filhos e o desejo de ser mãe. Parece ser no resultado dessa vetorização que o puerpério se desenrola: da possibilidade de o desejo de ter filhos se transformar no desejo de ser mãe.

Ter um filho remete a uma demanda de retorno e revivescência do narcisismo materno, ao passo que ser mãe impõe um radical descentramento de si, a necessidade de investir libidinalmente o filho como outro, mas estranhamente próximo e familiar.

Com a distinção de Labaki (2008) entre o desejo de ter filhos e o desejo de ser mãe - e o que implica para a mulher a mudança de um para outro -, podemos nos aproximar mais propriamente da nossa questão central: a experiência de ser mãe e o que esse percurso representa psiquicamente. A maternidade estaria no 
registro da separação e da perda, e não necessariamente do ganho, pois, para ter um filho, "ganha-se o bebê", mas, para ser mãe, devem-se perder as ilusões narcísicas, o ideal, o perfeito, o lugar de filha, alguém como complemento e até mesmo o "poder de fazer viver o bebê".

Devo, mais uma vez, assinalar que o nascimento de um primeiro filho produz um incremento de ansiedades profundas na mulher, em relação às quais uma causa importante é o fato de ativar fantasmas infantis de onipotência, em relação ao poder ilimitado que a maternidade oferece sobre a vida (e, em consequência, sobre a morte) de outro ser humano. Os primeiros tempos de um primeiro filho são uma situação limite, traumática, cujo saldo não depende apenas do equilíbrio psíquico prévio da mulher que atravessa essa experiência, senão também das intervenções simbolizantes e continentes daqueles que a rodeiam (Bleichmar, 1994, p. 17).

Assim, na maternidade, parece haver uma imposição necessária de primeiro se separar para depois perder o "forte amor da imagem refletida no espelho" (Freud, 2010a) e seus desdobramentos, para doar não só um lugar em seu corpo, mas também uma porção do próprio psiquismo àquele que chega. Parece que, ao se desprender de si mesma, o que a mulher perde na experiência da maternidade é exatamente essa porção de si que é endereçada ao filho e assim transmitida.

Podemos pensar que a gravidez é um tempo sumamente importante não só para a mulher construir espaço para o bebê que virá e a representação do bebê que carrega, mas também prepará-la para perder a imagem ideal do bebê:

A espera de um filho, durante a gravidez, bem como o investimento de desejo no filho que será adotado, deveria dotar a mãe dessa capacidade de perda da imagem ideal do bebê, sem a qual a criança não se subjetivaria. Não havendo subjetivação, tornar-se-ia, na melhor das hipóteses, um simulacro da psicopatologia materna. Mas, como nem toda espera prepara para o encontro, nem toda mulher se torna mãe. Digo mãe devotada, que se esquece e deixa nascer um projeto de alteridade (Labaki, 2008, p. 282).

O outro e o mesmo, o estranho e o familiar, narcisismo e alteridade, um termo parece estar intrinsecamente vinculado ao outro na construção da maternidade e a vinda de um bebê no horizonte materno.

O tema das perdas volta intensamente ao cenário. Que elementos ou condições deve ter uma mulher que the permita fazer um intenso trabalho de elaboração psíquica da perda? 


\section{capítulo 2}

\section{Os impactos e os destinos do nascimento}

Para clínicos e pesquisadores, é sempre fascinante pensar e retomar os textos de Freud, surpreendendo-se novamente ao acompanhar o curso de seu pensamento na construção de uma teoria como a psicanálise. É relevante destacar que o autor serviu-se da investigação dos modos comuns de expressão do psiquismo para, paralelamente, examinar os modos não tão comuns. Com isso, não só iluminou o terreno dos quadros psicopatológicos, como os aproximou de maneira brilhante a fenômenos cotidianos como sonhos, atos falhos, lapsos e o luto, indicando que, além de um desconhecido de base, há em nós as manifestações do inconsciente e também que não há fronteiras tão sólidas entre o que se pode considerar normal ou patológico. Há talvez uma linha tênue que os separa.

Tomando a especificidade da vida humana como pano de fundo e considerando que, nos primeiros tempos, todo ser precisa de alguém que o ampare - tamanha é sua prematuridade intrínseca -, devemos ter em mente que esse alguém que ampara foi também cuidado por um outro ser, nos seus primeiros tempos. Esteve na posição que agora seu filho ocupa, também está atravessado por questões, conteúdos, conflitos de toda espécie, muitos dos quais vêm transmitidos por gerações precedentes.

Fundamentalmente, cada ser vem ao mundo no contexto de uma (pré)história desenvolvida pelas gerações anteriores, de modo que os termos mais pertinentes não têm ligação com a culpa por possíveis disfunções ou desvios no filho. Partindo da premissa de que os fenômenos humanos são tingidos por determinações inconscientes e que uma mãe, um pai e outros membros da família são inevitavelmente afetados por esses conteúdos que não estão facilmente acessíveis - e menos ainda elaborados -, devemos considerar que eles muitas vezes imprimem certas formas de ser e/ou de reagir ao contato com o outro e com tudo o que ele traz.

Assim, tomando por base a especificidade da vida humana e considerando que, desde a gestação, o psiquismo materno assume um estado de transparência, compreendemos que o nascimento de um filho reativa não só o narcisismo dos pais, 
mas toda uma série de conflitos e lutos não suficientemente elaborados, que o filho faz ressurgirem, com sua necessidade de ser investido e amparado. Em uma palavra, ele traz à tona o desamparo de seus pais.

Ao longo da obra de Freud, o desamparo remete a uma variedade de questões. Primeiramente, o autor tratou o tema como resultado da total incapacidade concreta do recém-nascido de satisfazer suas necessidades mais vitais, para depois retomá-lo e elaborá-lo em termos da teoria da angústia (na qual esse estado remeteria a um caráter traumático). No fim, passa a marcar uma diferença radical: a de que o desamparo seria a dimensão essencial do funcionamento psíquico, reiterando sua total falta de garantias (Pereira, 2008).

O desamparo não aparece num momento específico da vida, mas marca profundamente a condição do ser e nunca é superado, apontando a precariedade da existência humana. Com o amadurecimento, podem-se angariar recursos psíquicos cada vez mais elaborados para fazer face a essa condição de base, e ele pode também representar a condição de abertura para o outro (Pereira, 2008).

Assim, compreendemos o espectro freudiano do desamparo, que vai desde os primórdios, em razão da insuficiência das condições de o pequeno ser manter-se vivo sozinho, passando pela vivência de seu eventual caráter traumático e chegando à noção da falta de garantias inerente à tessitura da vida psíquica - em suma, da vida inteira.

O desamparo parece oferecer-se como um solo psíquico, sempre presente, e às vezes mascarado por recursos que $o$ individuo vai adquirindo com a possibilidade oferecida pelo contato com um outro. Mas, em determinados momentos, pode emergir e se apresentar com toda a sua força excessiva e transbordante, como parece acontecer - em diferentes intensidades - com os pais quando do nascimento de um filho. Assim, o estado de desamparo do bebê - seja porque ele não se pode cuidar sozinho, seja pelo que há de traumático e excessivo nessa experiência - não só clama por cuidado e investimento, como parece ressoar, de certa forma, no desamparo dos pais. Talvez pela possibilidade de se identificar com o filho nesse estado os pais possam oferecer amparo cuidadoso, mas reverberando também algum sofrimento, pois a premência de cuidados e a necessidade de garantir a vida 
da criança - a mesma vida que não tem garantia nenhuma - trazem à tona o desamparo, e às vezes de forma brutal.

Então, sobre esse pano de fundo, podemos compreender a complexidade das questões envolvidas na vinda de um filho e no exercício da parentalidade. $O$ tecido que se forma nesse entrelaçamento aponta a necessidade de se metabolizarem essas várias forças, especialmente no que tange às transformações que as demandas de um filho impõem ao psiquismo dos pais. O processamento necessário na passagem do desejo de ter um filho para o desejo de serem pais envolve um trabalho psíquico - que podemos chamar de trabalho da parentalidade - e pode manifestar de diferentes modos: a depressão pós-parto pode figurar entre eles, bem como a tristeza saudável, fruto do impacto que o filho pode trazer.

\section{Depressão}

No mestrado (Folino, 2008), discutimos amplamente a depressão e a depressão que ocorre no período puerperal. Faremos agora um breve recorte do que se tratou ali, realçando os aspectos mais relevantes para esta pesquisa: o impacto do nascimento do filho para a mulher e o trabalho necessário para sua elaboração no exercício da parentalidade.

O tema da depressão é extremamente complexo e abrangente, pois pode representar uma infinidade de estados muitos diferentes entre si. Sabemos que, hoje, qualquer tristeza um pouco mais prolongada é frequentemente diagnosticada como depressão e medicada com antidepressivos, negligenciando-se completamente o fato de que, muitas vezes, essa tristeza condiz com uma dor decorrente de perdas importantes, além de necessária para a elaboração dessas perdas.

Nossa cultura desenvolveu uma intolerância absoluta à tristeza, e, para debelar essa verdadeira "inimiga pública", buscam-se, a todo custo e de forma idealizada, estados plenos de felicidade. $\mathrm{Na}$ contraparte, se repele tudo o que remeta a perda, dor ou reação natural de tristeza. Segundo Ceccarelli (2010), as contrariedades tornaram-se insuportáveis, transformando o sofrimento psíquico em 
doença mental. Por outro lado, vem tomando corpo a discussão sobre os efeitos da magnitude e do impacto da medicalização da sociedade e da patologização da vida, o que pode ser uma tentativa de se opor a essa imperiosa tendência.

Entretanto, não devemos subestimar o sofrimento gerado por um estado depressivo, menos ainda quando este irrompe no puerpério, com todo o universo de reverberações a que todos da família ficam sujeitos, e num momento em que o único sentimento socialmente autorizado é o de júbilo.

Evidentemente, há casos e circunstâncias específicas em que não se pode negligenciar a importância de um medicamento antidepressivo, cujo uso deve ser cuidadosamente acompanhado por um profissional competente e fará diferença para o sujeito. No entanto, sabemos que, na maior parte das vezes, prescreve-se esse tipo de medicamento sem as devidas precauções, numa total indiscriminação entre uma necessidade real e uma tentativa de fugir da dor, em caso de perdas inerentes à vida, em que a tristeza invariavelmente sobrevém.

Acresce-se que um quadro depressivo pode ser apenas a ponta do iceberg e que, mesmo bem administrado e acompanhado, o medicamento pode apenas amenizar os sintomas a ponto de a pessoa retomar minimamente a direção de sua vida, mas não mudará sua posição subjetiva.

Cabe lembrar que o termo psicopatologia remete às paixões da alma e ao sofrimento psíquico, o que implica compreender esse sofrimento e suas reverberações. No entanto, tem servido muitas vezes para "patologizar a normalidade", como "um discurso gerador de regras sociais e normas de conduta que são utilizadas para classificar, etiquetar e às vezes punir" (Ceccarelli, 2010, p. 126).

Essa é uma questão de suma importância e pode envolver o risco de também virmos a patologizar a maternidade e a construção da parentalidade. Por isso, não devemos perder de vista a complexidade desses processos, para indicar uma possível aproximação com o tema da depressão que acomete as mulheres na maternidade. Inicialmente, sabemos que ela pode acarretar prejuízos para a própria mãe e marcar sua relação com o bebê, com a possibilidade de isso também 
reverberar na família como um todo, o que, de saída, exige uma maior compreensão dos impactos do nascimento de um filho para o psiquismo materno.

O estudo anterior indicou que, apesar de ser os profissionais mais próximos da mulher e da família no começo de vida do bebê, os pediatras não se mostram, em geral, sensíveis à importância desses primeiros tempos de vida da criança com sua mãe ou aos sinais de que algo não vai bem na relação entre eles e que poderiam indicar dificuldades no exercício do papel materno, ou um eventual quadro de depressão após o nascimento do bebê, ou mesmo um baby blues (Folino, 2008).

Uma característica que complica muito a discriminação da depressão que surge no pós-parto é o fato de ela se apresentar latente e mascarada por sofrimentos somáticos e astenia (Kreisler,1999; Golse, 2003a), representada por uma perda ou diminuição das forças, algo próximo à perda do vigor. Em função disso, pode passar despercebida e se prolongar. A especificidade desse tipo de depressão materna é que a mãe funciona como se estivesse desconectada de seu filho, talvez emocionalmente ausente, agindo quase mecanicamente (Golse, 2003a; Mazet; Stoleru, 1990; Kreisler,1999; Green, 1988).

Também há casos em que - apesar de alguns sinais claros - um quadro depressivo mais definido passe sem o devido cuidado ou seja apenas medicado, sem outro amparo que permita compreender a situação específica daquela mulher em particular e ajudá-la a elaborar essa dificuldade, para suscitar uma mudança subjetiva de fato. Finalmente, pode acontecer de não haver nem medicação e nem sequer diagnóstico, e o sofrimento não só se prolonga como pode se cronificar, reverberando também de outras formas nos filhos, no casal etc.

Freud não abordou especificamente o tema da depressão, pois, em sua época, o conceito não existia tal como se o conhece hoje. $O$ termo depressão apareceu gradativamente em sua obra, para descrever uma e outra patologia, e, paralelamente, ele concebeu os fenômenos depressivos como próprios do existir humano. Em "Luto e melancolia", Freud (2010) fez uma aproximação e uma tentativa de elucidar a diferença entre as emoções que colorem as manifestações normais frente às experiências de luto $e$ as disposições que apareceriam no que ele demonstrou ser uma dificuldade na elaboração normal do luto. A isso, ele 
denominou melancolia, o que criou a possibilidade de se compreenderem as diferentes reações a uma perda significativa, abrindo uma importante trilha para outras contribuições ao tema.

$\mathrm{Na}$ elaboração normal da perda - o luto -, entraria grande parte das manifestações que se costuma chamar de depressivas - o choro, um certo recolhimento, a tristeza -, mas como parte de um processo que permitiria ao enlutado abandonar o objeto amado e aceitar sua perda, liberando-o para investir em outros objetos. No caso da melancolia, Freud (2010) acusa a presença das mesmas manifestações, acrescidas do que ele chama de "autoincriminações" - um rebaixamento do amor próprio que não se sente vergonha de expressar diante dos outros e uma dificuldade de aceitar a perda do objeto amado.

Assim, vemos, como é comum em Freud, uma aproximação que mostra uma espécie de delicado continuum entre saúde e doença e que só um estudo mais acurado poderá discriminar.

Por outro lado, com as elucidações de Melanie Klein (1996) sobre a posição depressiva, a depressão desloca-se para um ponto de importância ímpar: como constitutiva do desenvolvimento psíquico.

Klein (1996) concebe a posição depressiva como uma fase do desenvolvimento na qual o bebê reconhece e se relaciona com um objeto total, com aspectos bons e maus. Ele começa perceber que suas experiências boas e más procedem da mesma mãe, acarretando uma tristeza que a autora chamou de ansiedade depressiva, uma espécie de culpa arcaica e angustiada, fruto de sentimentos ambivalentes dirigidos ao mesmo objeto-mãe. A fantasia de ter destruído ou danificado o objeto impele o bebê a mobilizar esforços no sentido de reparar o que sente ter sido danificado, destruído e perdido. Seu ímpeto agora é proteger e reparar o objeto bom internalizado: "A ansiedade depressiva é o elemento decisivo dos relacionamentos maduros, a fonte dos sentimentos amorosos e altruístas que são devotados ao bem-estar do objeto" (Hinshelwood, 1992, p. 152).

O trabalho da posição depressiva assemelha-se ao trabalho do luto, e na vida adulta o luto arcaico é revivido inúmeras vezes, sempre que o pesar for novamente experimentado. Para a autora, quando termina o trabalho do luto, a pessoa enlutada 
"[...] não apenas recebe em si (reincorpora) a pessoa que acabou de perder, mas também reintegra objetos bons (em última análise, os pais amados)" (Klein, 1940, p. $353^{3}$ apud Hinshelwood, 1992, p. 157).

A posição depressiva é um marco no desenvolvimento psíquico humano. Vivê-la possibilita ao bebê integrar aspectos bons e maus do objeto e do próprio ego e favorece o aparecimento não só da culpa, mas da necessidade de reparar os objetos, fazendo com que o bebê se mobilize rumo a um contato maior com a realidade, deslocando-o, portanto, do mundo de fantasias onipotentes. Assim, a idealização pode gradativamente ceder espaço aos aspectos mais reais da experiência e dos objetos.

As contribuições da posição depressiva favorecem a formação simbólica na criança, preparando o terreno para a construção do pensar, usando a capacidade de vincular e abstrair. Portanto, enriquecem o psiquismo infantil, na medida em que o bebê passa inúmeras vezes por experiências de luto e reparação - com as quais constrói sua confiança em sua capacidade de reter e recuperar objetos - e toma contato com a crença em seu próprio amor e em seu potencial de ter experiências boas e gratificantes.

Por seu turno, Winnicott (2005b) concebe a depressão como uma capacidade, simbolizando que a passagem pelo desmame foi bem-sucedida, e o sentimento de perda e a capacidade de preocupação atravessaram a desilusão advinda do desmame. Para o autor, a depressão pode ser entendida como uma condição comum dos seres humanos integrados, os quais se responsabilizam por seu ódio e sua crueldade e cuja capacidade de amar vive lado a lado com esses sentimentos: "Por vezes, o sentimento de sua própria maldade as abate. Se considerarmos a depressão dessa forma, veremos que são as pessoas realmente valiosas deste mundo que se deprimem" (Winnicott, 2005b, p. 75-76).

Ao caracterizar a crise depressiva, Winnicott (2005a, p. 64) entende que a depressão é uma espécie de reavaliação interna que se faz quando há uma nova experiência de destrutividade face à presença do amor. O autor compara tanto o

\footnotetext{
${ }^{3}$ KLEIN, M. Mourning and its relation to manic-depressive states. The writings of Melanie Klein, v. 1, 1940. p. 344-69.
} 
humor depressivo quanto sua resolução a uma questão da combinação entre elementos internos bons e maus.

Apesar de acentuar o caráter valioso da depressão, pois ela traria o "germe da recuperação", Winnicott (2005a) não negligencia o sofrimento e o risco que correm as pessoas deprimidas, mas acentua a vinculação da depressão à capacidade de sentir culpa e à possibilidade de fazer o trabalho do luto, o que ele entende como um sinal de maturidade pessoal.

Em outro texto, ele distingue o conceito de posição depressiva, descrita por Klein, da depressão. Para ele, quando o bebê consegue se deprimir, é porque ultrapassou a posição depressiva: "Quando a posição depressiva foi alcançada e plenamente estabelecida num indivíduo, a reação à perda é a dor, ou tristeza. Se ocorreu alguma falha na posição depressiva, a consequência da perda é a depressão" (Winnicott, 2000b, p. 371).

Assim como Klein (1996), Winnicott (2005a; 2005b) parece situar a depressão em dois pontos: no campo da psicopatologia e no processo maturacional do ser humano. Considera que ela pode se arrastar por uma vida, sendo severa e incapacitante, bem como pode indicar, em indivíduos menos comprometidos, um humor passageiro, vinculando-se ao processo de luto e à capacidade de sentir culpa, fazendo com que eles possam ter ganhos, após o esvaecimento desse estado, e recuperar sua saúde mental.

\section{O trabalho do luto como trabalho de elaboração}

Como vimos em "Luto e melancolia", Freud (2010) concebe o luto como reação à perda de uma pessoa amada ou de uma abstração que ocupa seu lugar a pátria, a liberdade, um ideal etc. - e, embora possa levar a um sério afastamento da conduta normal da vida, não pode ser considerado um estado patológico. Sua superação demanda um certo tempo - que pode variar muito - para que se processe a perda. 
Na última tradução de "Luto e melancolia", Paulo César Souza (2010) observa que, em alemão, Trauer, significa tanto "luto" quanto "tristeza" e que o equivalente em português do adjetivo traurig é "triste".

$\mathrm{Na}$ tradução feita por Marilene Carone, de 1992, ela afirma que Trauer significa "tristeza profunda pela perda de alguém" e "luto", no sentido das marcas externas desse estado (vestir-se de luto, a duração do luto etc.). Comenta também que a proximidade das ideias de luto e de tristeza é, em alemão, mais evidente do que em outras línguas.

Fundamentalmente, o que nos parece relevante sublinhar é o caráter de tristeza profunda pela perda que subjaz à palavra "luto". A perda e a tristeza consequente impõem ao psiquismo um trabalho especifico chamado de trabalho do luto.

O trabalho do luto é descrito como um processo intrapsíquico que se segue à perda de um objeto de amor e pelo qual o indivíduo consegue desapegar-se progressivamente dele. Considera-se, assim, que o luto é o trabalho de elaboração da perda: "A noção de trabalho de luto deve ser aproximada da noção mais geral de elaboração psíquica, concebida como uma necessidade para o aparelho psíquico ligar as impressões traumatizantes" (Laplanche; Pontalis, 1986, p. 662-663).

Elaboração psíquica é:

[A] expressão utilizada por Freud para designar, em diversos contextos, o trabalho realizado pelo aparelho psíquico a fim de dominar as excitações que chegam até ele e cuja acumulação ameaça ser patogênica. Esse trabalho consiste em integrar as excitações no psiquismo e em estabelecer entre elas conexões associativas" (Laplanche; Pontalis, 1986, p. 196).

A perda significativa gera tristeza, junto de uma necessidade de absorver e metabolizar os excessos dessa experiência, exigindo um trabalho não só para lidar com o excesso, mas para encontrar modos possíveis de digerir a experiência e ultrapassá-la.

Cymrot (1997) acredita que houve uma modificação do conceito de elaboração psíquica, desde a primeira postulação de Freud, quando haveria a ideia de que algo deveria ser eliminado da vida psíquica. Ele passou a ser entendido 
como próximo de digestão, contenção, transformação, ressignificação, transitoriedade e insaturação: "a elaboração psíquica resulta do alcance da posição depressiva, da possibilidade do exercício do princípio da realidade pressuposto nesta posição" (Cymrot, 1997, p. 187).

Podemos pensar que o trabalho do luto mais propriamente é o trabalho da tristeza numa tentativa de processar as dores que as perdas acarretam e uma possibilidade de digerir e transformar a experiência do sujeito que as vive, o que exige um tempo que pode variar bastante. Nesses termos, o trabalho de elaboração das perdas presente no luto (tristeza) pode ser um avanço e uma possibilidade de desenvolvimento psíquico que seria impossível sem o necessário confronto com as dores.

Lembremos, com Coelho Junior e Luís Claudio Figueiredo (2012, p. 30), que na própria acepção da palavra "trabalho" está incluída a ideia de dor, pois travaglio em italiano quer dizer "dor". E que "as transformações requerem e implicam trabalho".

Por outro lado, a depressão poderia indicar uma dificuldade de processar as perdas e transformá-las, ressignificando-as na experiência.

Para compreender as forças envolvidas na vivência da mulher no nascimento de um filho, percorreremos a literatura a respeito do estado denominado baby blues. 


\section{capítulo 3}

\section{A respeito do baby blues}

\section{Sobre o nome}

Inicialmente, intrigou-nos a multiplicidade de formas pelas quais se nomeia 0 blues na literatura: vários nomes definem o mesmo quadro. Depois, nos perguntamos o motivo de tantas nomeações para um único estado: por que sua denominação não é consensual? Além de baby blues, encontramos postpartum blues (ou blues do pós-parto), maternity blues (ou blues materno, ou da maternidade), blues puerperal, transitory syndrome (ou síndrome transitória), síndrome da tristeza pós-parto, melancolia do pós-parto (ou puerperal), the blues, third day syndrome (ou síndrome do terceiro dia), disforia do terceiro dia e emotional oversensitivity syndrome, entre outros.

Os vários nomes que designam um único quadro parecem indicar certa dificuldade para uma concordância sobre o que o blues representa. Ele parece ser visto de diversas formas, mas pensamos que é interessante primeiro nos aproximarmos do termo blues e de sua origem.

\section{O que representa esse nome?}

Antes ainda de discutir o termo, notemos que, além de significar a cor azul, blues se aplica informalmente a pessoas ou condições como um equivalente de sad e without hope ("triste" e "sem esperança") e dá nome a um tipo de música lenta e triste do sudeste dos EUA, tocada pelos negros de New Orleans. Por fim, também informalmente, descreve o estado de tristeza (Longman Dictionary of Contemporary English, 1978).

Segundo Dayan (1999, p. 52), em inglês e alemão, o "bleu é a cor da tristesse (tristeza) e da morosité (de sombroso, sombrio). O equivalente em francês será o 
noir (negro) como na expressão broyer du noir ('estar na fossa', 'deprimido', 'reduzido a pó')". ${ }^{4}$

A palavra blues tem origem num ritmo musical e é bastante controversa. Teria surgido em torno do fim do século XIX e início do XX, entre trabalhadores negros africanos que entoavam as work songs nas lavouras de algodão na região próxima ao Delta do Mississipi, no chamado Cotton Belt (Herzhaft, $1989^{5}$ apud Alves, 2011).

O blues surgiu como um gênero poético declamado e cantado por escravos, sem acompanhamento harmônico (Giddins; Deveaux, $2009^{6}$ apud Palmeira, 2011), e com uma tendência melódica descendente (Palmeira, 2011). A blue note é uma característica essencial desse ritmo e pode ser entendida como uma nota mais expressiva, semelhante a um lamento, normalmente interpretada como melancólica.

Além de ter inspirado o surgimento de vários outros gêneros musicais nos EUA, fruto da miscigenação de culturas, o blues é considerado por alguns, mais que apenas um ritmo musical, a representação de um estado - arriscaríamos dizer emocional. Estudiosos do tema consideraram-no um estado de espírito ou o meio pelo qual se expressa esse estado (Oliver, $1978^{7}$ apud Alves, 2011).

O termo blues também evoca a saudade que os escravos sentiam da terra natal, "da mãe África perdida" (Bydlowski, 2007, p. 185), o que nos dá elementos interessantes para depois retornarmos o tema mais diretamente.

\section{Um pouco mais de história. . .}

Há também certa controvérsia sobre como se teria descrito inicialmente o quadro de baby blues. Para Jouppe (2007), foi Savage que, em 1875, o mencionou como um leve transtorno puerperal sem necessidade de internação, associado à banal "febre do leite".

\footnotetext{
${ }^{4}$ Neste capítulo, são tradução nossa os excertos de Bensoussan (2013), Bydlowski (2007; 2013), Dayan (1999; 2008), Drossart (2004), Faisal-Cury (2008), Henshaw (2003), Jouppe (2007), Murray e Cooper (1997), Pitt (1968; 1973), Rochette (2003; 2005; 2007a; 2007b; 2010) e Rohde et al. (1997).

${ }^{5}$ HERZHAFT, Gérard. Blues. Campinas: Papirus, 1989.

${ }^{6}$ GIDDINS, Gary; DEVEAUX, Scott. Jazz. New York: W. W. Norton \& Company, 2009.

${ }^{7}$ OLIVER, Paul. The story of the Blues. New York: Penguin Books, 1978.
} 
Dayan (1999; 2008) recomenda cautela ao se equivalerem o blues do pós-parto com a apojadura, popularmente conhecida como descida do leite, e a chamada "febre do leite". Para o autor, foi Marcé, em 1858, que evocou uma "suscetibilidade particular de certas mulheres durante o estado puerperal". Pensamos que essa equivalência talvez se deva ao período em que aparecem tanto a apojadura quanto o blues.

Muitos autores concordam que só depois de 1950 a discussão do blues puerperal voltou ao cenário das perturbações puerperais.

Em 1952, Moloney chamou o quadro de blues do terceiro dia, e Victoroff o denominou blues da maternidade; Hamilton (1962), por sua vez, propôs síndrome transitória do terceiro dia, uma vez que compreendia o quadro para além do sentimento do blues; ampliando a descrição do fenômeno, (Dayan, 1999) incluiu afetos de euforia, que também podem acompanhar o estado.

Pitt (1968) se vale da expressão "Atypical Depression Following Childbirth" para descrever um quadro diverso do blues, que seria a depressão puerperal, entendendo o blues como uma depressão típica e normal após o parto.

No mesmo ano, Yalom et al. (1968, p. 16) escreveram um artigo em que enfatizam e resumem as principais questões relativas ao estado:
A ligeira depressão transitória que ocorre após o parto é tão onipresente e aparentemente benigna que não tem sido considerada digna de um estudo sério. Por conseguinte, existe uma incerteza considerável sobre as características básicas e o significado dessa síndrome [...]. A ligeira depressão do puerpério tem vários aspectos intrigantes. Embora esteja associada a uma fase crítica do ciclo de vida, a disforia curiosamente ocorre após o parto, em um momento em que se poderia esperar que as mulheres estivessem se sentindo alegres (grifos nossos).

Os aspectos intrigantes que os autores destacam parecem dignos de discussão, sublinhando o caráter plural da síndrome, o que já havíamos notado no levantamento bibliográfico sobre o tema e pela diversidade de nomes pelos quais se a designa. Por um lado, justamente pelo fato de ser tão onipresente $e$ aparentemente benigna, não terá merecido estudos aprofundados; por outro, 
destoando do que se espera da mulher depois do parto, despertou o interesse de pesquisadores da época.

É curioso que, no mesmo ano de 1968, os dois trabalhos tenham discutido dois quadros clínicos vizinhos, ambos transtornos psíquicos no pós-parto. Bydlowski (2013) acredita que esses artigos podem ter lançado no cenário de pesquisa certa confusão conceitual entre as noções de blues e de depressão puerperal.

\section{Afinal, o que é o blues materno?}

Como vimos, o blues tem interessado inúmeros pesquisadores, em virtude de seu caráter algo enigmático, como possível preditor de um quadro mais sério como a depressão puerperal e ainda, segundo acreditam Kennerley e Gath (1989), pela possibilidade de lançar luz na etiologia dos distúrbios de humor.

Descrito por vários autores, o quadro não parece ter características consensuais. Além disso, apesar de ser um achado bastante comum, sua ocorrência pode variar de $15 \%$ a $85 \%$, variação possivelmente devida à diversidade de métodos diagnósticos utilizados (Dayan, 1999).

O blues costuma se manifestar no terceiro dia após o parto e pode chegar até o décimo, e alguns autores sugerem que pode durar apenas algumas horas ou alguns dias. No entanto, os diferentes sintomas têm picos de prevalência variável. De modo geral, parece haver um pico de intensidade do blues em torno do quarto ou quinto dias depois do nascimento, uma particularidade desse estado (Kennerley; Gath, 1989), e há parturientes que experimentam um blues agudo (Yalom et Coll., 1968; Pitt, 1973).

Alguns autores relatam choros e depressão transitória no puerpério imediato (Pitt, 1968; 1973), outros, uma reação depressiva branda envolvendo fadiga, desânimo, dificuldade de pensar claramente e choro sem motivo (Moloney, $1952^{8}$ apud Pitt, 1973; Henshaw, 2003).

\footnotetext{
${ }^{8}$ MOLONEY, J. C. Post-partum depression or third-day depression following childbirt. New Orleans Child Parent Digest, n. 6, p. 20-32, 1952.
} 
Em 1962, Hamilton ${ }^{9}$ (apud Pitt, 1973; Henshaw, 2003) entrevistou enfermeiras com experiência no cuidado de novas mães e seus bebês, e elas relatavam fadiga, choro, ansiedade, confusão, dor de cabeça, insônia, hipocondria e hostilidade com o marido.

No mesmo ano, Robin (1962 ${ }^{10}$ apud Henshaw, 2003) entrevistou mulheres no oitavo ou nono dia após o parto e encontrou como queixa labilidade emocional e uma "depressão de curta duração".

Por outro lado, há autores que não concordam que a depressão faça parte do espectro do blues (Kennerley; Gath, 1989), e Cox; Connor; Kendell (1982 ${ }^{11}$ apud Hershaw, 2003) e Yalom e Coll (1968) pensam que a mulher não está necessariamente deprimida quando chora. No entanto, o que parece ser importante é a labilidade emocional. Algumas mulheres relatam experimentar tristeza e alegria ao mesmo momento, e as alterações podem acontecer algumas vezes por dia (Hershaw, 2003).

Segundo Szejer e Stewart (1997), o baby blues pode se apresentar como uma leve depressão ou como lágrimas que podem durar o dia todo, mas difere da depressão clássica, aproximando-se mais de um estado de fragilidade e hiperemotividade acompanhado de tristeza e choro intermitentes, seguidos de humor bem próximo do habitual.

Quanto às características arroladas pelo estudo sobre o tema, Dayan (1999) cita o trabalho de Stein (1982), ${ }^{12}$ que oferece as descrições mais detalhadas:

- choro: É o sintoma mais frequente. Algumas mulheres têm um sentimento de despersonalização acompanhado de algumas lágrimas ou de uma verdadeira crise. Essas crises de choro são precipitadas por pequenos desconfortos ou

\footnotetext{
${ }^{9}$ HAMILTON, J. A. Post-partum Psychiatric Problems. St Louis: The C. V. Mosby Company, 1962.

${ }^{10}$ ROBIN, A. A. The psychological changes of normal parturition. Psychiatric Quart, n. 36, p. 129-150, 1962.

${ }^{11}$ COX, J.; CONNOR, Y.; KENDELL, R. E. Prospective study of the psychiatric disorders of childbirth. Br J Psychiatric, n. 140, p. 111-117, 1982.

${ }^{12}$ STEIN, G. The maternity blues. In: BROCKINGTON, I. F.; KUMAR, R. (Eds.). Motherhood and mental illness. London: Academic Press, 1982, p. 119-154.
} 
decepções como, por exemplo, atitudes do marido e dificuldades de alimentação do bebê. Os choros não são necessariamente acompanhados de uma expressão de tristeza, mas mais frequentemente de ansiedade, irritabilidade ou mesmo exaltação, alegria ou sentimento de despersonalização.

- humor depressivo: Dayan (1999) ressalta que não se trata de uma depressão clínica, mas muito mais de um sintoma, uma vez que as mulheres exprimem um sentimento de fadiga e abatimento.

- exaltação do humor: Manifesta-se por certa euforia (Martinet, 2008), e há uma difícil distinção a fazer entre uma "exaltação adaptada" e uma sintomatologia. Em alguns casos, pode haver um estado de hipomania (Dayan, 1999).

- labilidade de humor: Há também certa controvérsia a respeito dessa característica. Alguns autores descrevem a alternância entre choro e excitação como muito frequente, sendo o sintoma prevalente, mas há outros, como é o caso de Kennerley e Gath (1989), que, segundo Dayan (1999), descrevem as crises de choro como sintoma prevalente.

- confusão: Acompanhada de perturbações da memória e distração (Dayan, 1999; Martinet, 2008).

- despersonalização: "As mães sentem-se estranhamente separadas de seu bebê e manifestam culpa no caso de humor deprimido ou crise de risos motivada por sentimentos bizarros, no caso de humor expansivo, parece refletir a sensação de estranhamento que sentem em relação ao seu próprio corpo e de seu bebê. Quando essa característica ocorre entre o quarto e o sétimo dia após o parto, pode sugerir um blues mais severo" (Dayan, 1999, p. 56-57).

- perturbações do sono: Devido às demandas do bebê e a outros fatores, sabemos que o sono no puerpério é frequentemente perturbado, além da diminuição das horas de sono, e pode haver sonhos com afetos intensos e pesadelos (Dayan, 1999; Martinet, 2008). 
Há ainda sintomas como irritabilidade (associada à tendência depressiva), agitação (que acompanha os estados de exaltação e os estados mistos) e esgotamento. A manutenção desse estado pode estar associada a uma depressão de humor, anorexia, angústia, cefaleias e tendências ao esquecimento.

Rohde et al. (1997) pesquisaram o blues materno em brasileiras e verificaram que os sintomas mais característicos são a hipersensibilidade e a emotividade exacerbada. Em decorrência disso, sugerem que a síndrome pudesse ser chamada de emotional oversensitivity syndrome, ao invés de maternity blues. Ainda levantam um ponto importante: acreditam que é difícil autoavaliar a tristeza e a depressão quando se acaba de ter um bebê - e o instrumento de pesquisa foi um questionário autoaplicado.

\section{Rastreamento do blues}

Como vimos, os autores convergem para o fato de que é uma síndrome aguda, transitória, breve e comum e não parece ser um problema sério na prática clínica (Kennerley; Gath, 1989). O’Hara (1997) lembra ainda que o estado não deixa muitas consequências negativas, e há autores que acrescentam que ele não prejudica a capacidade da mãe de cuidar do bebê.

Muitas pesquisas defendem a importância de se conhecer melhor o quadro. Para tanto, por meio de escalas e entrevistas clínicas, vários estudos rastrearam o quadro e muitos usaram escalas criadas originalmente para detectar sintomas depressivos (Nott et al., 1976: Handley et al., 1980; Ballinger et al., 1982; Manley et al., 1982; Cutrona, $1983^{13}$ apud Kennerley; Gath, 1989). No entanto, não é consensual que os sintomas depressivos façam parte do blues.

Outras escalas foram desenvolvidas especificamente para medir o blues (Pitt, 1973; Stein, 1980; Kendell et al., $1981^{14}$ apud Kennerley; Gath, 1989), mas não por métodos psicométricos sistematizados, o que levou Kennerley e Gath (1989) a desenvolverem um questionário que as mães se pudessem autoaplicar diariamente

\footnotetext{
${ }^{13}$ CUTRONA, C. E. Causal attributions and perinatal depression. Journal of Abnormal Psychology, n. 92, p. 161-172, 1983.

${ }^{14}$ KENDELL, R. E.; MC GUIRE, R. J.; CONNOR, Y. et al. Mood changes in the first three weeks after chilbirth. Journal of Affective Disorders, n. 3, p. 317-326, 1981.
} 
por certo período, posto que os pesquisadores consideram essencial a avaliação diária nos dez primeiros dias, devido à rapidez das mudanças de humor ocorridas no puerpério imediato.

Uma das questões intrigantes da referida pesquisa é que os autores apontam a característica que nos parece primordial no blues - o fato de não haver consenso em torno do tema. Um exemplo disso é o caso das três escalas desenhadas anteriormente para detectar o blues: todas têm 28 itens, mas apenas três coincidirem.

Outra questão intrigante é que, na única escala que foi sistematicamente desenvolvida e validada, a de Kennerley e Gath (1989), o item mais frequente não foi DEPRESSION, mas LOW SPIRITED, que podemos traduzir por desanimado. Os autores entendem que uma possível explicação é que as mulheres entrevistadas usaram o termo depressão para dizer de uma disforia severa, e não era o caso do sentimento a que se referia a grande maior parte delas.

\section{Tentativas de conhecer ainda mais o blues materno}

Por considerarem-na uma depressão "típica" e "normal" do puerpério, vários autores atribuem sua causa às drásticas mudanças hormonais comuns desse período. Outros o entendem não como uma resposta específica ao parto, mas como uma "reação final" que pode decorrer de qualquer estressor físico (Yalom et al., $1968{ }^{15}$ apud lles et al., 1989), semelhante ao movimento depressivo que persiste depois de uma prova importante ou intensa, seja de natureza intelectual ou esportiva (Bydlowski, 2007), e há os que entendem os sintomas com momento e intensidades particulares, especificas do blues materno (lles et al., 1989).

Em face dessas duas visões conflitantes, lles et al. (1989) pesquisaram dois grupos de mulheres: um depois do parto e outro depois de cirurgias ginecológicas. Aplicando em ambos o questionário de maternity blues, de Kennerley e Gath (1989), encontraram resultados diferentes: as mulheres no pós-operatório tiveram resultados significativamente mais altos nos dez dias após a cirurgia, que diminuíram de forma

\footnotetext{
${ }^{15}$ YALOM, I.; LUNDE, D. T.; MOOS, R. H. et al. Post-partum blues syndrome: a description and related variables. Archives of General Psychiatry, n. 18, p. 16-27, 1968.
} 
constante do segundo para o décimo dia, enquanto as mulheres no pós-parto tiveram um pico de prevalência dos sintomas no quarto ou no quinto dia.

Esses resultados levaram os autores a concluir que as mulheres no pós-parto têm uma condição especifica, e não uma resposta genérica a uma experiência estressante, e que sua causa ainda é desconhecida, uma vez que ainda está por confirmar, mesmo com pesquisas cuidadosas, a associação entre as alterações de humor e as mudanças hormonais de estrógeno e progesterona ocorridas no puerpério (lles et al., 1989).

Faisal-Cury et al. (2008) alertam para o fato de que também não há consenso sobre os riscos de a mulher desenvolver o blues, e um dos critérios diagnósticos tem sido a duração e a intensidade dos sintomas.

Parece haver uma forte indicação que, apesar de próximos, o blues e a depressão puerperal são quadros distintos (Lanzick; Brown; Stump, $1992^{16}$ apud Faisal-Cury et al., 2008), uma vez que as pacientes com depressão apresentam sintomas mais intensos e duradouros do que as de blues.

Os autores enfatizam ainda a importância de haver novas pesquisas, especialmente em psicologia, que esclareçam melhor o diagnóstico, a etiologia e o prognóstico, favorecendo medidas preventivas, uma vez que a prevalência do quadro e sua possível associação com a depressão puerperal podem acarretar prejuízos para a mulher e, portanto, para a família como um todo. Salientam ainda a dificuldade de obstetras e ginecologistas diagnosticarem e lidarem com essas questões (Faisal-Cury et al., 2008).

Henshaw (2003, p. 40) faz uma revisão dos estudos sobre as perturbações de humor no puerpério e constata não haver consenso entre os autores sobre a relação entre o blues e uma subsequente depressão puerperal:

[...] a relação mais convincente encontrada entre a perturbação de humor no puerpério imediato foi a disforia na gravidez, uma história passada de depressão, "neuroticismo", depressão pré-menstrual e depressão no período pós-parto, sugerindo ser um marcador de vulnerabilidade afetiva. $E$ que os correlatos biológicos são inconclusivos.

\footnotetext{
16 LANCZIK, M.; BROWN, G.; STUMP, K. Post-partum blues: depressive disease of pseudi nerasthenic syndrome. Journal of Affective Disorders, n. 25, p. 47-52, 1992.
} 


\section{O blues materno e os hormônios}

Muito discutida também é a associação entre o blues puerperal e as drásticas mudanças hormonais do momento após o parto, sem precedentes em nenhuma outra circunstância da vida da mulher, tamanhas são sua rapidez e magnitude. Esses hormônios devem voltar a seus valores anteriores à gravidez em poucos dias após o parto (Wieck, 1996; O'Brien; Pitt, $1994^{17}$ apud Figueiredo, B., 2003), de modo que, tendo levado nove meses para atingir certo patamar até o fim da gestação, decrescem vertiginosamente no puerpério.

Basicamente, no puerpério imediato, se reduzem drasticamente a progesterona e a prolactina, hormônios que se foram gradativamente aumentando ao longo de toda a gestação, e há também um súbito incremento da prolactina, essencial para a amamentação, e, no final da gravidez, da ocitocina, fundamental para as contrações uterinas no momento do parto, bem como para a secreção do leite materno (Gyton, $1986^{18}$ apud Figueiredo, B., 2003).

Sobre a etiologia do blues materno e das variações hormonais, alguns autores afirmam que se deve principalmente à queda da quantidade de progesterona (Gelder, 1978; Nott et al., $1976^{19}$ apud Figueiredo, B., 2003) e de estrógenos (Appleby, $1990^{20}$ apud Figueiredo, B., 2003; Kennerley; Gath, 1989) e ao incremento da prolactina (George; Copeland; Wison, 1980 ${ }^{21}$ apud Figueiredo, B., 2003). Há ainda uma possibilidade de haver a interferência dos altos índices de cortisol na ocasião do parto (Taylor et al.,22 1994 apud Figueiredo, B., 2003).

\footnotetext{
${ }^{17}$ O'BRIEN, S.; PITT, B. Hormonal theories and therapy for postnatal depression. In: COX, J.; HOLDEN, J. (Eds.). Perinatal Psychiatry. London: Gaskell, 1994.

${ }^{18}$ GYTON, A. C. Tratado de fisiologia médica. Rio de Janeiro: Guanabara, 1986.

${ }^{19}$ NOTT, P. et al. Hormonal changes and mood in the puerperium. British Journal of Psychiatry, $\mathrm{n}$. 128, p. 379-383, 1976.

${ }^{20}$ APPLEBY, L. The aetiology of postpartum psychosis: Why are there no answers? Journal of Reproductive and Infant Psychiatry, n. 8, p. 107-116, 1990.

${ }^{21}$ GEORGE, A. J.; COPELAND, J. R.; WISON, K. C. Prolactin secretion and the postpartum blues syndrome. British Journal of Pharmacology, v. 70, n. 102, 1980.

${ }^{22}$ TAYLOR et al. Serum cortisol levels are related to moods of elation and dysphoria in new mothers. Psychiatry Research, n. 54, p. 241-247, 1994.
} 
Junto com outros pesquisadores (Miller; Rukstalis, $1999^{23}$ Nonacs; Cohen, $1998^{24}$ apud Figueiredo, B., 2003, p. 528), a autora também vincula a aparição do blues a uma maior reatividade emocional da mulher aos estímulos, o que seria um facilitador de sua aproximação do bebê, garantindo sua sobrevivência "na expressão subjetiva da ativação puerperal do sistema biológico que promove a ligação afetiva da mãe ao bebê". O que, no entender da autora, concorre para a vinculação materna ao bebê parece-nos próximo à noção de apego de Bowlby (2006). Assim, a resposta biológica refletida pelas alterações hormonais no puerpério estaria a serviço da vinculação primária da mãe com seu filho.

Em virtude de seu caráter fugaz, o blues não tem recebido muita atenção dos terapeutas, sendo interpretado como um modelo de manifestação psíquica secundário às alterações hormonais que se seguem ao parto (Dayan, 1999). O autor também enfatiza que, apesar de ser numerosas, as pesquisas nesse sentido não permitem nenhuma conclusão formal.

Por sua vez, embora não negue que ela possa produzir efeitos, Szejer (1997; 2002) se opõe veementemente à hipótese hormonal para a causa do blues, dando dois fatos observados: as mães que dão à luz um bebê prematuro não fazem um quadro de baby blues nos dias que se seguem ao nascimento, mesmo tendo uma alteração hormonal após o parto. A autora enfatiza o caráter ainda mais surpreendente do fenômeno no caso de mulheres que adotam uma criança: não tendo havido gestação, não há bruscas alterações hormonais, mas, mesmo assim, o blues se impõe nos dias que se seguem à chegada do bebê em casa.

\section{Pelas tramas do blues materno: o olhar de Myriam Szejer}

Especialmente interessante foi tomarmos conhecimento de que, no início de seu trabalho com bebês, Myriam Szejer começou a estudar o baby blues num grupo de reflexão sobre o tema e elaborou, em conjunto com outros profissionais, um

\footnotetext{
${ }^{23}$ MILLER, L.; RUKSTALIS, M. Beyond the "Blues": Hypotheses about postpartum reactivity. In: MILLER, L. (Ed.). Postpartum mood disorders. Washington DC: American Psychiatry Press, 1999. p. 3-20.

${ }^{24}$ NONACS, R.; COHEN, L. Postpartum mood disorders and treatment guidelines. Journal of Clinical Psychiatry, n. 59, p. 34-40, 1998. Suplement 2.
} 
questionário para mães que, na época, foi aplicado em consultórios particulares de ginecologistas. A recorrência de algumas respostas chamou a atenção dos pesquisadores, especialmente uma:

Assim, na pergunta: caso isso lhe fosse proposto, você aceitaria falar com um profissional sobre os problemas que teve depois do parto?, o "sim" predominava de forma ampla nas respostas provenientes de mulheres que eram mães. Essa resposta era particularmente chamativa porque, naquela época, como ainda hoje na maioria dos atendimentos públicos, não havia nada previsto a priori para 0 acompanhamento das puérperas. Os problemas dos primeiros meses eram sempre tratados na pediatria, quando se tratava da criança, e eventualmente em psiquiatria, no caso da mãe. Mas na maternidade não existia nada específico nesse sentido. No entanto, a demanda parecia existir (Szejer, 1999a, p. 32-33).

Pensamos que essa questão é de suma importância para nossas reflexões neste trabalho, pois acreditamos que, na realidade atual brasileira, estamos longe de oferecer um cuidado desse tipo a quem acaba de ter um filho, apesar das inúmeras evidências da necessidade fundamental desse tipo de assistência.

A hipótese de Szejer (1997; 2002, p. 203-204) versa sobre a presença do bebê que provocaria o blues materno: é ele que impõe um "remanejamento psicológico", e são simultâneos o aparecimento do blues, o ganho de peso do bebê (aumento de sua curva ponderal, após uma queda) e o surgimento do leite materno. Com a chegada do bebê, cada membro da família deve encontrar um novo lugar, e suas demandas impõem inapelavelmente à mãe a "responsabilidade e a dor da separação, que tem ecos muito fortes em seu inconsciente".

Simbolicamente, o blues representaria a maneira com que a mulher transmite a seu filho uma herança, que, com sua tristeza, ficaria "menos poderosa e menos presente" no momento em que seu filho ganha um "lugar", dado por ela, e "força para existir" (Szejer, 2002, p. 204). A autora alerta ainda para o fato de que, nesses momentos da chegada de um novo membro na família, há uma "agitação dos cadáveres", concernente a conflitos e lutos não elaborados.

Numa tradição lacaniana, Szejer (1999b, p. 20) enfatiza o lugar do bebê humano como um ser de linguagem e as implicações desse lugar:

Do ponto de vista do inconsciente da mãe, o baby blues pode ser entendido como uma reatualização dos lutos e separações não 
simbolizados de sua história. É como se as portas de todos os armários que contêm os cadáveres de sua história se abrissem simultaneamente. A carga afetiva ligada a essas rupturas, a esses não ditos geralmente inconscientes, provoca uma espécie de aspiração psíquica da criança, que vem ocupar seu lugar como ser de linguagem (aliás, costuma-se dizer que é nesse período do terceiro-quarto dia que o recém-nascido começa a se exprimir). A partir daí, ele pode entrar em sua historicidade; a história está sempre atrás de nós.

O tempo do surgimento do blues materno parece representar 0 reconhecimento do bebê como um outro ser, um individuo único, diferente de tudo o que se imaginava (Szejer, 1997), bem como diferente da própria mãe.

A autora acentua que, para a mãe, a experiência mais intensa após o parto é justamente a consciência da separação de seu filho e suas repercussões. Os primeiros dias do pós-parto são um período de transição e de dias difíceis, no qual sua vivência é de profundo descentramento. Durante os meses de gestação, o bebê parecia manter seu "centro de gravidade", e o parto precipitou um desequilíbrio no corpo e no psiquismo materno (Szejer, 1997, p. 276).

A autora considera esse tempo fundamental para que a mulher tome consciência da real presença de seu filho, de sua "alteridade", e que saia de certa forma de seu "espanto" (Szejer, 1997, p. 301).

Segundo Szejer (1999a, p. 158), há dois momentos fundamentais para o recém-nascido: o nascimento propriamente dito e o acesso à vida simbólica, seu nascimento como sujeito, que deve vir banhado de palavras. É esse momento a posteriori que ela acredita ser o tempo "crucial" do baby blues e concomitante ao nascimento simbólico do bebê, operado por uma castração, um corte simbólico que faz com que os pais não tomem o bebê como prolongamento de si mesmos, mas lhe destinem um lugar na linhagem familiar que vai além deles. Nesses termos, Szejer inclui também o pai no fenômeno do baby blues.

Esse momento delicado é fortemente marcado pela aceitação por parte dos pais de uma perda irreversível e uma renúncia:

Do lado da mãe, a castração consiste em aperceber-se de que ela tem diante de si um verdadeiro ser humano, um sujeito bebê [...]. É para ela o momento de perceber que, embora seja a autora de seu filho, não é a única. O corpo do filho era locatário do seu, mas nem 
por isso ela é sua proprietária. Ela precisa de certo tempo para mentalizar essa distância entre ela e o filho. É o tempo do limbo, e o do baby blues que o encerra (Szejer, 1999a, p. 162).

\section{O olhar de Monique Bydlowski}

Para Bydlowski, foi Paul-Claude Racamier que, com seu trabalho pioneiro sobre psicose puerperal, lançou luz sobre uma concepção psicodinâmica e psicanalítica dos transtornos da maternidade. Ele cunhou o termo maternalidade e levou à ideia de que, mesmo a psicopatologia puerperal mais grave, como é o caso da psicose puerperal, seria "a evolução conflitiva de processos normais" (2007, p. 185). Segundo Silva (2004, p. 9), Racamier define maternalidade como "o conjunto dos processos afetivos que se desenvolvem e se integram na mulher por ocasião da maternidade".

De acordo com Bydlowski (2007), o "abatimento" puerperal que o blues representa tem uma causa bastante complexa; além das alterações hormonais em curso, há ainda a hipótese - já mencionada aqui - de que o movimento depressivo seja inerente a qualquer evento muito intenso, como uma prova física ou intelectual.

A autora pondera que o blues seria a "tradução emocional" de um duplo fenômeno: uma sensação de perda da gestação, ou o luto por um objeto interno que a acompanhou alguns meses, e o estado particular do psiquismo da mulher, de "desnudamento psíquico", que the permite estar em conexão próxima com o filho nesses primeiros tempos. Esse abatimento seria, então, reflexo da desorganização do eu materno em curso desde a gravidez, o que explicaria sua universalidade (Bydlowski, 2007, p. 185).

$\mathrm{Na}$ interpretação de Martinet (2008), Bydlowski (2007) atribui o blues do pós-parto ao estado de transparência psíquica inerente ao final da gestação e aos primeiros dias do bebê.

Bydlowski (2007) evidencia o caráter necessário do blues dando uma importante contribuição: relegando seu caráter patológico e recolocando-o no cenário das mudanças esperadas com a vinda de um filho não pelo viés puramente 
biológico, sem entretanto negá-lo. Ela ainda alerta para o fato de que ninguém ao redor da mãe sabe como reagir a esse enigmático estado; há apenas uma banalização, comentada por muitos outros autores, como é o caso, por exemplo, de Patrick Bensoussan (2013).

O autor discute o fato de o baby blues ter se tornado na França uma espécie de banalização do sofrimento da mulher. Num trabalho intitulado $O$ baby blues não existe, ele lança certa provocação, pois entende que essa ideia acabou se tornando, para os médicos, um modo de calar as mães e, assim, de se desvencilhar de seus transtornos físicos e psíquicos. Bensoussan (2013) acredita que "dizer a essas mulheres que o que elas têm não é grave, que vai passar em breve, não só pode banalizar seu estado como frustrar suas demandas mais genuínas de ser ouvidas e sustentadas por uma forte presença psíquica tão necessária nesse momento".

Monique Bydlowski (2007) adverte que devemos considerar a possibilidade de estar diante de um quadro patológico, uma depressão pós-parto, quando o estado descrito se torna severo e passa a durar mais de oito dias. Portanto, um blues severo pode ser indicador de um quadro de depressão, mostrando-se mais evidente da sexta à oitava semana após o nascimento (Fossey; Papiernik; Bydlowski, 199725 apud Bydlowski, 2007).

Embora não os cite nominalmente, Martinet (2008, p. 201) ressalta que muitos autores consideram a hipótese de que o blues é um "equivalente de um trabalho de luto" pela perda da criança da gravidez e do lugar privilegiado de grávida, com sua sensação de potência e plenitude, bem como o luto pela perda da criança imaginária para dar lugar à criança real. Também alerta que a mulher, o marido e a família como um todo devem ter a atenção e o cuidado de profissionais, especialmente de obstetrícia e pediatria, para identificar e acompanhar o estado. E acredita ainda que se deve ficar atento a um blues muito intenso com nuance disfórica, que pode ser um critério de evolução para um quadro de depressão pós-parto.

${ }^{25}$ FOSSEY, L.; PAPIERNIK, E.; BYDLOWSKI, M. Post-partum blues: a clinical syndrome and predictor of postnatal depression?. Journal of Psychossomatic Obstetrics and Gynecology, n. 18, p. 17-21, 1997. 


\section{O olhar de Jacques Dayan e Rozsika Parker}

Sobre o fato de que a natureza do blues continua sendo discutida em torno de três vértices - um transtorno transitório de adaptação, um distúrbio de humor e uma reação emocional normal -, Dayan (2008, p. 26) pensa que o nascimento de um filho exige da mulher "uma adaptação quase imediata a um evento que ressignifica os contornos do sentimento de identidade, a definição dos papéis sociais, a imagem corporal e as relações às figuras de apego".

Ainda segundo Dayan (1999), o trabalho de Parker (1997) mostra um ângulo de leitura especialmente interessante a respeito da universalidade da ambivalência materna, sua relação com a psicogênese do blues e o surgimento de elementos de natureza depressiva no pós-parto. Além de favorecer a diferenciação, a possibilidade de a mulher reconhecer em relação ao bebê sentimentos ambivalentes de amor e hostilidade aumentaria seu investimento nele, bem como seu senso de responsabilidade. No entanto, esse movimento parece ser acompanhado de sentimentos de perda, da necessidade de um trabalho de luto e da consciência de ser separado.

A ambivalência teria um valor criativo, no sentido de que pode favorecer na mãe uma profunda reflexão acerca do bebê ou da criança mais velha e de sua relação com ela, pois a autora acredita que isso pode ser feito ao longo da vida. Caso a mulher recuse completamente a ambivalência, a relação com o filho pode perder grande parte de sua riqueza, tendo como possível resultado a dificuldade da mãe para compreender seu bebê (Parker, 1997).

A autora alerta para a patologização da ambivalência materna, o que dificultaria tomá-la como algo construtivo e capaz de fornecer elementos valiosos na discussão do tema (Parker, 1997).

\section{O olhar de Francis Drossart}

O autor chama de "hiato do pós-parto" o momento cronológico correspondente ao baby blues. No entanto, metapsicologicamente, o vincula ao conceito kleiniano de "reparação da posição depressiva" e o compreende a partir de duas noções: a de "preocupação materna primária" e a de "transparência psíquica". 
$\mathrm{Na}$ preocupação materna primária, diferentemente de Winnicott, Drossart (2004) sublinha a ideia de hiato e de descontinuidade como parte importante e inerente ao fenômeno e ainda relaciona esse "hiato ao vazio de afetos ligado à expulsão real ou fantasmática da criança intrauterina". Assim, acredita que haja uma "fantasmatização da criança morta", e, assim, "a criança real, objeto do investimento psíquico materno", ocupa sistematicamente, com essa hipótese, um lugar de "criança substituta". O autor também acredita que "o hiato do pós-parto corresponde ao momento de fechamento da 'transparência psíquica'” (DROSSART, 2004, p. 208).

Invertendo uma certa lógica, sugere que, para haver nascimento de fato, outra criança tem que morrer. Assim, reforça ainda mais não só a ideia do momento de transição que o pós-parto imediato representa, como a de que os tempos da perinatalidade são potencialmente traumáticos e desorganizadores, exigindo um verdadeiro trabalho de luto e de elaboração.

\section{O olhar de Joëlle Rochette}

Rochette (2007a), por sua vez, sublinha a grande riqueza em que se constitui para clínicos e pesquisadores o pós-parto imediato, apesar de ainda ser pouco explorado do ponto de vista metapsicológico. Ela acredita que é simultâneo ao aparecimento do baby blues.

A autora entende que há uma trajetória importante entre o nascimento e quadragésimo dia e que esse "tempo é mais teórico do que puramente cronológico" - é um "marco na construção do primeiro vínculo". Articula o "momento dos quarenta dias", um tempo importante para mãe, para o bebê e para o entorno, quando ela pensa que se devem "afinar" essas "três partituras". Esse seria o tempo de uma necessária "afinação dos instrumentos" (Rochette, 2007a, p. 86). Ela considera esse momento fundamental, do ponto de vista cultural, e pode-se compreendê-lo como o tempo de retorno da mãe ao espaço social e a apresentação do bebê a esse espaço. Rochette (2007a, p. 86) ressalta sua importância por uma aproximação aos ritos de passagem estudados por Gennep (2011), essencialmente a cerimônia de relevailles, que era um rito religioso católico no qual a Igreja dava sua benção à 
mãe, que, simultaneamente, levava o bebê para o contato social, apresentando-o ao grupo, após ter ficado em casa no período de resguardo.

A autora também acentua que esse "espaço-tempo", hoje tão apartado dos rituais da cultura, corresponderia ao "trabalho psíquico do pós-parto", e não apenas a um "tempo biológico" (Rochette, 2007a, p. 86), convicção de que compartilhamos.

Rochette (2007b) alerta para a centralidade de se considerar o blues puerperal uma "regressão salutar e uma forma particular de desconstrução/construção propícia ao encontro com a imaturidade e o arcaico do bebê" e destaca a importância de se acompanhar a díade, uma vez que o vínculo mãe-bebê e o desenvolvimento do bebê podem sofrer se o blues apresentar uma recidiva ou se prolongar até o segundo mês.

A partir dos ensinamentos de René Kaës, Rochette (2005, p. 11-12) afirma que o psiquismo nasce apoiado tanto nos corpos quanto no grupo, de modo que há um "duplo escoramento que funda a humanização e o pensamento". Ainda citando Kaës, diz que "não é nunca uma mãe sozinha que dá à luz", pois, desde que chega ao mundo, o bebê é recebido e contido no grupo, na família, pela "mãe da mãe" e na vizinhança.

Tanto a mãe quanto o grupo familiar e o próprio bebê precisam de vários e "sucessivos après-coups para tornar representável e compartilhável o acontecimento inaugural do nascimento" (Kaës, $1979^{26}$ apud Rochette, 2005, p. 12).

Citando Guillaumin (1982 ${ }^{27}$ apud Rochette, 2005, p. 13), a autora destaca ainda a importância, depois de Freud, de levarmos em conta o "trabalho do sonho e do trabalho do luto como necessários para a psique metabolizar os acontecimentos".

Compartilhamos mais uma vez da assertiva da autora, que se aproxima da nuance traumática que pode conter o nascimento de uma criança: "O nascimento é sempre um momento próprio a transbordar as capacidades de elaboração individual e grupal e a gerar algo traumático" (ROCHETTE, 2005, p. 13).

\footnotetext{
${ }^{26}$ KAËS, R. Crise, rupture et dépassement. Paris: Dunod, 1979.

${ }^{27}$ GUILLAUMIN, J. Le traumatisme et l'expérience des limites. Quinze études psychanalytiques sur Le temps, traumatisme et après coup. Paris: Privat, 1982.
} 
Rochette também menciona Carel (1989 ${ }^{28}$ apud Rochette, 2005), que contribui com o tema cunhando a expressão traumatose familiale, que designa esse traumatismo do nascimento, quando, segundo o autor, em pouquíssimo tempo, há um aumento muito expressivo de excitação no psiquismo, induzindo uma falha na elaboração pelos meios habituais e podendo provocar transtornos duráveis no funcionamento energético.

O trabalho de Guedeney, Brunbergerk e Widlocher (1993 ${ }^{29}$ apud Rochette, 2005, p. 14) também é lembrado pela autora, enfatizando outro aspecto que julgamos primordial: que o blues do pós-parto "é um sinal de boa saúde materna", exceto se ele ultrapassa limites preocupantes, fazendo surgir um quadro de depressão pós-parto propriamente dita: "as variações emocionais do pós-parto permitem à mãe experimentar uma gama de experiências afetivas e afinar uma sensibilidade que vai ser indispensável para perceber e dar sentido às mensagens de seu bebê".

A partir de uma contribuição de Kreisler (1966) ${ }^{30}$ sobre os transtornos psicossomáticos precoces, Rochette (2005, p. 15) salienta que, nesses primeiros tempos, os conflitos psíquicos "não são alojados no psiquismo individual, por meio de uma 'angústia sinal', mas são difundidos na intersubjetividade, gerando um sofrimento no vínculo".

As "fronteiras permeáveis" que aprendemos com o conceito de "transparência psíquica" no período perinatal, forjado por Bydlowski (2002; 2007), não diz respeito apenas ao psiquismo materno - essa permeabilidade de fronteiras está presente no psiquismo de cada um dos participantes - mãe, pai, irmãos e bebê -, bem como entre eles, apontando para a questão da intersubjetividade. Rochette nota que esse modelo é bem conhecido dos analistas de grupo, lembrando o "aparelho psíquico

\footnotetext{
${ }^{28}$ CAREL, A. Transfert et périnatalité psychique. La fonction alpha à l'épreuve de la naissance. Gruppo, n. 4, p. 49-67, 1989.

${ }^{29}$ GUEDENEY, A.; BRUNBERGER, C.; WIDLOCHER, D. Le post-partum blues: une revue critique de la littérature. Psychiatrie de l'Enfant, v. XXXVI, n. 1, p. 329-54, 1993.

${ }^{30}$ KREISLER, L. La clinique psychosomatique de l'enfant. À propôs dês troubles fonctionnels du norrison. Psychiatrie de l'Enfant, v. IX, n. 1, p. 138-56, 1966.
} 
grupal" de Kaës (1999 ${ }^{31}$ apud Rochette, 2010): quando necessário, deve-se proceder a um tratamento do grupo, e não apenas de um de seus membros.

O aparelho grupal é um espaço comum da mãe e do bebê; é ele o responsável pela experiência harmônica que pode ter o bebê ao ser contido e entendido por sua mãe. Por outro lado, há às vezes um sofrimento sem identidade ou localização clara, derivado de "ansiedades primitivas que não são sentidas diretamente pelo self, mas dispersas no ambiente, desafiando a capacidade de contenção e de processamento da psique individual e grupal” (Rochette, 2010, p. 181).

Esse sofrimento disperso no ambiente aparece frequentemente em pedidos repetidos de consultas ao pediatra, numa ansiedade mascarada por questões muitas vezes centradas no bebê mas de origem não claramente conhecida, relativa provavelmente a esse tempo difícil do pós-parto, quando não há mais na nossa cultura meios de escoamento e metabolização no grupo social, nem aos menos nas famílias, e os pais acabam por ficar solitários na tarefa de "suportar" todas as forças a que se veem sujeitos nesse período. Em muitos casos, a sobrecarga é ainda maior para as mulheres.

Em trabalho anterior (Folino, 2008), a fala de um dos pediatras, bastante sensível às sutilezas da relação pais-criança, testemunhou o quanto pode ser difícil para os profissionais lidarem com uma demanda de cuidado que fica centrada na criança mas que é essencialmente maior, mais dispersa e mais dificilmente discriminável.

Rochette (2005, p. 15) sublinha essa questão com o intuito de repensar o suporte cultural que temos dado aos pais na delicada experiência de ter um filho. Como já vimos, há nas sociedades modernas um malogro dos ritos de passagem, que em outros tempos favoreciam a contenção e a metabolização das experiências de transição. Para a autora, "repensar as premissas da proteção materna e infantil, trabalhar com o simbólico e com a demanda latente dos jovens pais que multiplicam as visitas pediátricas poderia ser uma forma de rever o trabalho da cultura".

\footnotetext{
${ }^{31}$ KAËS, R. Les théories psychanalytiques du groupe. Paris: PUF, 1999.
} 
Essas ansiedades primitivas dispersas no ambiente podem tornar-se patológicas e patogênicas, e sabemos que os efeitos da depressão puerperal materna no bebê podem ser provas disso (Tronick; Weinberg, $1998^{32}$ apud Rochette, 2010). A autora também destaca a gravidade do tema, mencionando o que Carel (199733 apud Rochette, 2010, p. 181) chamou de "doença familiar", pois há casos em que o puerpério pode levar a um "colapso da família". Rochette (2007b, p. 82) prefere a expressão "sofrimento familiar primitivo" não mentalizado, justificando-o com uma "labilidade da sintomatologia e uma difusão de sinais dificilmente decodificáveis pelos cuidadores".

Suas contribuições sugerem a ampliação do universo do período relativo ao nascimento do bebê, do pós-parto e de suas reverberações, alertando para a necessidade de forjarmos recursos para ajudar as famílias e os pais a passarem por esse período de transição, acompanhados e contidos por novos suportes oferecidos pela cultura. Assim, como muitos outros autores na França, Rochette trabalha não só com a necessidade de tratamento das díades com problemas, mas enfatiza a extrema necessidade de se prevenirem transtornos, uma vez que sabemos o quão delicados são esse período e suas reverberações.

De acordo com Rochette (2003, p. 94), o grupo pode ser fundamental para dar contorno à experiência do nascimento, "momento particular de passagem e de mutação". Um dos dispositivos que a autora preconiza é o grupo de apresentação de bebês, com formato pensado para facilitar um certo ritual: "O grupo é como um envelope continente em torno dos elementos brutos ainda não mentalizados, frente à invasão irrepresentável do 'a mais' do nascimento”.

Reiteradas vezes a parentalidade e a maternidade são tratadas em nosso meio como um assunto particular, privado de cada casal ou de cada mãe, sem se levar em conta o quanto estamos enlaçados a uma dada cultura, de modo geral, e, de modo específico, à cultura familiar de cada membro do casal.

\footnotetext{
${ }^{32}$ TRONICK, E. Z.; WEINBERG, M. K. A propos dês conséquences toxiques psychiques de la dépression maternelle sur la régulation émotionnelle mutuelle des interactions mère-bébé. In: MAZET, P.; LEBOVICI, S. (Eds.). Psychiatrie périnatale. Paris: PUF, 1998.

${ }^{33}$ CAREL, A. L'après-coup générationnel. In: Le générationnel. Paris: Dunod, 1997. p. 69106.
} 
Inúmeros autores acentuaram a importância de compreendermos os elementos sociais e culturais que estão em jogo no caminho da parentalidade. Moro (2005, p. 258) alerta para a necessidade de termos em mente que:

Os elementos culturais se misturam e se imbricam com os elementos individuais e familiares de maneira profunda e precoce. Mesmo quando nós acreditávamos tê-los esquecido, a gravidez, por seu caráter iniciático, nos traz à memória nossos pertencimentos míticos, culturais, fantasmáticos.

Trabalhando num contexto transcultural da maternidade, com mães migrantes na França, a autora destaca que há muitas maneiras de se tornar pai e mãe, de dar à luz e de acolher a criança e seu sofrimento. Sublinha o prejuízo subjacente à não compreensão de aspectos extremamente relevantes, quando não incluímos a questão mais ampla de que todo nascimento está envolto por aspectos maiores do que a esfera individual ou a do casal.

Em nome de uma universalidade vazia e de uma ética reducionista, nós não integramos essas lógicas complexas, sejam elas sociais ou culturais, em nossos dispositivos de prevenção de cuidados e em nossas teorizações. Nós nos interrogamos raramente sobre a dimensão cultural da parentalidade, mas, sobretudo, nós não consideramos que essas maneiras de pensar e de fazer são úteis para estabelecer uma aliança, compreender, prevenir, tratar. Nós estimamos sem dúvida que a técnica é nua, sem impacto cultural, e que é suficiente aplicar o protocolo para que o ato seja corretamente realizado (Moro, 2005, p. 259).

Estudando o blues do pós-parto, percebemos que, apesar de pouco discutido em nosso meio, é um tema não só importante como fascinante. Partimos dele como uma hipótese psicopatológica, fazendo fronteira com a depressão pós-parto, e chegamos a um ponto no qual ele parece adquirir mais sentido, podendo simbolizar o trabalho psíquico que toda mulher deve fazer no momento em que dá à luz um filho, pois esse é por excelência um fato que "transborda", adquirindo nuances traumáticas.

Pensando nos ritos de passagem, eles indicam o trabalho necessário que se deve fazer em momentos de transição, e a maternidade e a parentalidade são momentos particularmente eivados de "atravessamento de fronteiras". 
Depois desse percurso pelos ritmos do blues, podemos compreender melhor o que ele representa: é algo que nos interpela, nos escapa, escorrega nas características que adquire, em seu significado e em como se pode refletir no árduo trabalho de nomeá-lo e lhe dar contorno. 


\section{capítulo 4 \\ Sobre a pesquisa}

\section{Justificativa}

Esta pesquisa visa iluminar as vivências psíquicas da mulher no puerpério, com especial destaque de aspectos referentes ao que a literatura denomina baby blues, mas que aqui será enfocado mais especificamente como lutos e sinais de sofrimento psíquico também presentes no caminho da construção da parentalidade a cada nova gravidez que aconteça na família. Além disso, pretende subsidiar os profissionais da saúde que atendem mães, separadamente e/ou com seu bebê. Acreditamos que os elementos apresentados podem auxiliar e favorecer um pensamento mais abrangente no cuidado à família, dando a conhecer mais profundamente as vivências em jogo na parentalidade.

Pensamos que o mérito e a função da pesquisa acadêmica é concorrer para a ampliação de um campo do conhecimento e oferecê-lo para a melhoria das condições de saúde e de vida da população. Assim, entendemos que é estritamente necessária a discussão de políticas públicas que visem uma rede de apoio maior para a gestante e a puérpera, uma vez que, em pesquisa anterior, verificamos que os pediatras, profissionais fundamentais nos primeiros tempos da vida da criança e da família, não são, em geral, instrumentalizados para perceber quando algo não vai bem na relação dos bebês com sua mãe, especialmente no que tange à percepção de sinais de depressão pós-parto, seja no bebê, na mãe ou na relação entre eles.

Nossa cultura tem uma visão claramente idealizada da maternidade, dificultando a expressão e a continência da ambivalência de sentimentos despertados quando do nascimento de um filho. Assim, negligenciam-se aspectos fundamentais, que podem acarretar prejuízo não só para a mulher, como para o bebê, para a relação entre ambos e para a família como um todo.

Em função disso, exploramos aqui as questões envolvidas nesse momento e suas possíveis reverberações, a partir de uma pesquisa científica cuja questão central é: o sofrimento conhecido pelo nome de baby blues, significado como um sentimento normal que acompanha a experiência das mulheres logo após o parto, 
pode ser entendido como um representante do processo de elaboração das vivências do período puerperal? Como o instrumental psicanalítico pode concorrer para uma melhor compreensão da especificidade desse momento da vida da mulher?

\section{Objetivo geral}

Verificar os estados psíquicos da mãe durante o período pós-parto e que recursos ela desenvolve para lidar com o trabalho psíquico necessário ao enfrentamento dos lutos desse processo e para a construção da parentalidade, que se dá a cada nova gravidez.

\section{Objetivos específicos}

Observar as nuances da relação mãe-bebê no final da gestação e durante os primeiros três meses de vida do bebê.

Investigar ao longo do período estudado quais são as principais perdas e lutos a ser enfrentados.

Verificar eventuais manifestações de estados depressivos tanto na mãe quanto no bebê e suas repercussões no vínculo.

\section{Pesquisa qualitativa e método psicanalítico}

Adotamos aqui uma abordagem qualitativa e o método psicanalítico.

Na metodologia qualitativa de pesquisa, enfatiza-se a compreensão do objeto de estudo ou do fenômeno escolhido. Portanto, o acento maior não está propriamente nos resultados, mas no caminho percorrido e nas observações que se fizeram no percurso, ou seja, mais propriamente no processo do estudo (Rey, 2002). 
Turato (2005) especifica melhor essa definição ao afirmar que a metodologia qualitativa não busca estudar o fenômeno em si, mas compreendê-lo como expressão de um significado - individual ou coletivo - para a vida das pessoas, uma vez que ele tem uma função organizadora para o ser humano. Outra característica é que a pesquisa se dá no ambiente natural do sujeito, sendo o pesquisador seu próprio instrumento de pesquisa. Nesses termos, a validade dos dados coletados passa a ser inquestionável, pela proximidade do pesquisador à essência da questão em tela. Por fim, não se generalizam resultados, mas os conceitos construídos e/ou o conhecimento original produzido: "Caberá ao leitor e consumidor da pesquisa usálos para examinar sua plausibilidade e utilidade para entender casos e setting novos" (Turato, 2005, p. 510).

Nesses termos, pensamos que a postura de um pesquisador qualitativo se assemelha à de um psicanalista em seu ofício. Quando escolhemos nos servir da psicanálise como balizador teórico desta tese, valemo-nos dela como um enquadre pelo qual observamos os fenômenos que se nos apresentam. É por meio dela e de seus instrumentos que nos debruçaremos sobre o material e sobre a experiência vivida nas entrevistas com as participantes da pesquisa em dois momentos: na gestação e após o nascimento do bebê.

Ao se lembrar das palavras e do espírito de Freud como fundador da disciplina, vários autores psicanalíticos acentuam que, ao falar sobre psicanálise, também nos referimos à esfera da pesquisa contida em seu exercício. Psicanálise e pesquisa estão intrinsecamente enlaçadas desde as origens do movimento psicanalítico e estão presentes no fazer de todo psicanalista, seja ou não um pesquisador vinculado a algum programa de pós-graduação (Mezan,2006; Herrmann, 2004; Figueiredo; Minerbo, 2006; Naffah Neto, 2006).

Ao explorar a expressão pesquisa em ciência, Mezan (2006) a circunscreve como uma tentativa de se obter conhecimento novo e de apresentá-lo de modo a vir a ser incorporado ao que já existe, como complemento ou como uma nova perspectiva ao tema abordado. Especificamente em relação à psicanálise usada como método em pesquisa acadêmica, esclarece que, apesar da diversidade dos temas estudados, existe um ponto comum entre as teses que vem orientando há vários anos: 
[...] todos os autores identificam uma questão e a investigam com os meios conceituais oferecidos pela psicanálise. Com frequência, as noções empregadas para estudar o problema escolhido saem revigoradas do embate com aquilo que foram convocadas a esclarecer [...] (Mezan, 2006, p. 233).

Como psicanalistas e pesquisadores dedicados a compreender os fenômenos que se nos apresentam de modo a ampliar o olhar sobre um campo de conhecimento, estamos fazendo ciência e, para isso, precisamos contar com alguns instrumentos. A atenção flutuante e a associação livre são as "ferramentas básicas" (Naffah, 2006, p. 279) de que dispomos para ter acesso ao que está ocorrendo na cena que se manifesta e que é vivida no espaço intersubjetivo da transferênciacontratransferência.

O pesquisador passa a ser um elemento fundamental nesse espaço intersubjetivo que se abre ao se considerarem o sujeito da pesquisa e quem a conduz. Nesses termos, esse tipo de pesquisa considera a presença de dois sujeitos que se inter-relacionam e afetam reciprocamente. No entanto, cabe ao pesquisador, ao longo do trabalho, ir encontrando sentidos e formando tecidos de compreensão de suas possíveis respostas contratransferenciais frente ao que o participante vai imprimindo à cena.

Colhendo dados numa entrevista ou observando como a mãe se relaciona com seu bebê, recolhemos mais do que dados objetivos sobre aquilo que ela nos conta, pois sua própria forma de falar conta mais do que a princípio ela acredita ter dito. Apesar de fazer parte dos procedimentos da pesquisa, essa ação de coletar e reunir já nos fornece elementos preciosos sobre como se revela aquele sujeito único. No entanto, para que isso venha a integrar o universo da pesquisa, devemos dar prioridade a alguns estados, que destacaremos a seguir.

Trinca (2002) ressalta que a qualidade do espaço mental do pesquisador é fundamental na relação que estabelece com seu objeto de pesquisa. $O$ autor postula como mobilidade psíquica a atitude central do pesquisador, que deve poder ter uma atitude mental de fluidez para poder acolher e desvendar os fenômenos que também se apresentam fluidos. Para ele:

A apreensão de fenômenos sutis em Psicanálise exige uma abertura para níveis de contato profundos com eles. Deve-se conseguir a 
libertação do espaço interno do pesquisador e a ampliação de seu nível de consciência, a fim de que esta se torne ressonância para emergências de toda natureza (Trinca, 2002, p. 196).

Assim, ele compara o pesquisador a um "rio caudaloso que recebe o imenso fluxo de vida".

Quando há mobilidade psíquica, normalmente emergem um ou alguns focos nodais do material como um todo, e Trinca (2002) os compara ao fato selecionado descrito por Bion (1966). Para que seja viável uma pesquisa psicanalítica a partir desse modelo, há que se somar outra condição à mobilidade psíquica: num segundo momento, separado da investigação aberta e livre, aplicamos o pensamento sistemático, pelo qual a pesquisa tem dois momentos, que se complementam e enriquecem - intuição e organização são os dois operadores desse modo de pesquisar:

Desse ponto de vista, a pesquisa psicanalítica comporta dois lados, a saber: a mobilidade psíquica e a organização do pensar, a intuição e a razão, o conteúdo do estado de experiência e a forma do pensamento, 0 aspecto inestrutural e o aspecto estrutural dos fenômenos (Trinca, 2002, p. 201).

Assim, somando-se a intuição à organização, a pesquisa psicanalítica não só é mais eficiente e profunda, como tem mais pulsação, fica mais viva, ao acompanhar mais de perto os movimentos internos e as manifestações mais sutis, seja dos sujeitos da pesquisa, seja de seu impacto no "pesquisador-sujeito".

Outro importante aspecto a realçar é o caráter interventivo do olhar psicanalítico. Desde Freud, curar e investigar (Freud, 1926 ${ }^{34}$ apud Mezan, 2006) sempre formaram um todo, e a psicanálise não parece se propor a separar esses dois campos. Dessa forma, pensamos que, ao desenvolver uma pesquisa dentro da universidade, devemos ter em mente que, apesar de esse não ser o objetivo primeiro do pesquisador, alguma intervenção terá havido em seu trabalho de investigar e pesquisar, seja pela própria natureza de seu "objeto" de pesquisa, seja por sua relação com esse "objeto".

\footnotetext{
${ }^{34}$ FREUD, S. Die Frage der Laienanalyse. In: 1975[1926]. p. 271-349. 
Não é preciso interferir intencionalmente para intervir de fato. A esse respeito, é esclarecedora essa afirmação de Figueiredo e Minerbo (2006, p. 260):

A entrega do "pesquisador" ao "objeto", o deixar-se fazer por ele e, em contrapartida, construí-lo à medida que avançam suas elaborações e descobertas faz desta "pesquisa" um momento na história de uma relação que não deixa nenhum dos termos tal como era antes de a própria pesquisa ser iniciada. Isso é mais óbvio em uma situação "terapêutica", mas a atitude clínica pode se manifestar em outras condições e sempre terá como efeito a transformação das partes em jogo, o "objeto" e o "sujeito" da pesquisa [...].

Apesar de muitas vezes a intervenção não ser objetivo prioritário de uma pesquisa, decorre da especificidade do encontro humano - mesmo num universo de pesquisa científica - alguma interferência no campo que se está investigando. Não podemos deixar de levar em conta esse aspecto, uma vez que nossa própria forma de ver o fenômeno humano - a partir do referencial psicanalítico - é matizada por elementos que tentam ver, ouvir, entender e sentir para além do que a princípio está dado.

Concordamos com Figueiredo e Minerbo (2006, p. 260) quando dizem que interpretar é olhar o fenômeno de forma não habitual: "O olhar do psicanalista é um olhar fora da rotina, que desopacifica o objeto. Ele ressurge diferente, desconstruído, transformado. O sujeito também se transforma, na medida em que se torna capaz de ver coisas que não via antes".

E a transformação não se limita ao sujeito, mas muitas vezes atinge de forma contundente aquele que pesquisa. Assim, parece desenvolver-se um fenômeno correlato no pesquisador, como pessoa e como profissional, pois ele também é permanentemente implicado e modificado no processo que se desenrola no decorrer de seu trabalho de pesquisa.

Aqui desaparece a respeitosa distância entre "pesquisador" e "referencial teórico" para dar lugar a um corpo-a-corpo do qual a psicanálise, Deus seja louvado, não sairá tal como entrou. Isso é, aliás, digno de nota: na academia ou fora dela, uma "pesquisa com método psicanalítico" é sempre obra de psicanalista e capaz de trazer novidades à própria psicanálise (Figueiredo; Minerbo, 2006, p. 259). 
Para promover algum acréscimo ao campo de conhecimento, esse embate entre a psicanálise e o pesquisador é não são só necessário como desejável para quem empreende um caminho de pesquisa pelo método psicanalítico. Em última instância, parece intrínseca à pesquisa a possibilidade de um alargamento do campo que se propõe a estudar.

\section{Procedimentos}

Em face dos objetivos explicitados, optamos por fazer entrevistas semidirigidas, distribuídas desde os três meses antes do parto até em torno do terceiro mês de vida do bebê. Alguns temas nortearam cada entrevista. $\mathrm{Na}$ gestacional, foram: a gestação e suas repercussões, sobre o bebê, o nome. $\mathrm{Na}$ primeira entrevista pós-parto: o parto, como estavam a participante e o bebê, a amamentação e a participação do companheiro.

O desenho da pesquisa incluiu um encontro antes do nascimento do bebê para que uma aproximação com a mulher ainda grávida facilitasse os encontros no período puerperal, uma vez que pretendíamos entrevistá-las logo após o parto, preferencialmente na primeira semana. Além disso, a entrevista antes do parto nos poderia dar acesso às fantasias que antecedem o encontro com o bebê real.

Assim, houve ao todo quatro ou cinco encontros com cada participante e, com exceção do primeiro, que se deu ainda durante a gestação, os outros tiveram uma frequência mensal, duraram cerca de uma hora e contaram com a presença da dupla mãe-bebê, na casa das participantes.

Excepcionalmente, com apenas uma das participantes, fizemos duas entrevistas no período gestacional, por dois motivos: pelo fato de ela estar na transição do segundo para o terceiro trimestre, e não da metade do terceiro para o fim, como pretendíamos, e de ter sido a primeira pessoa da amostra a ser encaminhada - não julgamos prudente adiar a entrevista e correr o risco de perder sua participação.

A proposta de acompanhar essas mulheres e observá-las na relação com seus filhos foi apresentada a médicos obstetras e pessoas ou profissionais 
conhecidos, que as encaminharam para o estudo. A estes e às próprias participantes foi informado tratar-se de uma pesquisa para examinar a relação desenvolvida durante os três primeiros meses de vida do bebê observando possíveis manifestações de estados depressivos e seus impactos no vínculo mãe-bebê. Foi explicitado ainda que a pesquisa faz parte de um trabalho de doutorado desenvolvido no Instituto de Psicologia da Universidade de São Paulo, o qual foi submetido e aprovado pelo Comitê de Ética em Pesquisa do Hospital Universitário da mesma universidade.

Após a indicação do nome da interessada em participar da pesquisa, fizemos um contato telefônico, no qual explicamos como seria sua participação: uma entrevista no último trimestre da gestação, um reencontro preferencialmente depois de uma semana do nascimento do bebê, em sua residência, e mais duas entrevistas, aproximadamente um e pouco mais de dois meses após o nascimento. Explicamos os objetivos gerais da pesquisa, frisamos o caráter voluntário da participação, que tampouco envolveria qualquer ônus financeiro e poderia ser interrompida em qualquer momento anterior à publicação da tese de que a pesquisa é parte. Depois desses esclarecimentos, marcamos um horário de acordo com a disponibilidade da pessoa e no local que ela indicasse.

O primeiro encontro começava com a entrega do Termo de Consentimento Livre e Esclarecido (Anexo A) à participante. Depois de lê-lo e preenchê-lo com seus dados, esta o assinava em duas vias e ficava com uma; a outra ficava na posse da pesquisadora. Além disso, informava-se à participante que as entrevistas seriam gravadas em áudio.

As entrevistas posteriores ao nascimento do bebê foram feitas em presença deste, pois era preciso investigar como se ia estabelecendo a dinâmica da relação entre eles. De minha parte, eu estava atenta a elementos que de alguma forma norteavam minha atenção, tomando cuidado para manter a atenção flutuante e levando em conta o clima emocional de cada encontro.

A partir dos elementos observados, hipotetizamos aspectos da dinâmica inconsciente presente no discurso da mãe, bem como nos elementos observáveis eu sua relação com o bebê antes e depois do nascimento. 
Nos casos em que se verificassem dificuldades específicas, sugerir-se-ia o atendimento pertinente.

As entrevistas foram gravadas e depois transcritas, tendo sido o material analisado de dois modos: o primeiro, caso a caso, considerando-se suas singularidades; o outro, no todo, a partir de confluências entre os casos que permitam alguma generalização.

Durante esses procedimentos, estive atenta ao clima emocional instalado nos encontros, de que acredito poder recolher dados preciosos não só sobre a relação que se estabelece entre a mãe e seu bebê, mas também sobre a que ela desenvolveu comigo, o que reputo fundamental para compreender amplamente o fenômeno que se me apresentou não só como observadora, mas como copartícipe do processo, do encontro com cada gestante e, depois, com cada mãe e seu filho.

Assim, a contratransferência se mostra um precioso instrumento psicanalítico na pesquisa e é mais um elemento na análise do material. Pela observação de si mesmo e pautado tanto por sua própria análise quanto pela experiência de escuta, o pesquisador psicanalítico pode identificar e refletir os impactos gerados num encontro especifico.

\section{Sujeitos}

As participantes da pesquisa foram mulheres grávidas no terceiro trimestre de gestação, preferencialmente da metade deste para o fim, que aceitaram ser acompanhadas, junto com seu bebê, durante o primeiro trimestre após o parto, mais ou menos.

Não se consideraram fatores de exclusão do estudo como classe social, situação socioeconômica ou cultural, idade da mãe ou o fato de ela ser primípara ou multípara.

A amostra foi composta por cinco mulheres entre 26 e 38 anos, três das quais eram primigestas e duas já tinham um filho. Todas as participantes moravam com 0 pai do bebê e tinham ensino superior completo; duas delas tinham carreira 
acadêmica. Com exceção de uma, as demais participantes trabalhavam no momento do estudo.

Na discussão dos resultados e nos comentários às entrevistas, fizemos uma opção linguística: todas as crianças são referidas como "bebê" ou pela forma "filho" (tomada como neutra), uma vez que não nos detivemos em aspectos relativos à diferença de gêneros.

\section{Aspectos éticos do projeto e análise de riscos e benefícios}

Assegurou-se às participantes da pesquisa sigilo quanto às informações de cunho pessoal, com as devidas mudanças de nome e dados que as pudessem identificar.

Apresentamos o Termo de Consentimento Livre e Esclarecido da forma mais clara e objetiva possível e, ao longo de toda a pesquisa, esteve aberta a possibilidade para qualquer esclarecimento ou recusa da participante.

Considerando minha conduta ética e continente diante dos sujeitos da pesquisa, não acredito que haja nenhum risco em sua participação neste estudo. Quanto aos possíveis benefícios, concernirão a cada dupla mãe-bebê, e não podemos avaliá-los a priori.

\section{Instrumentos}

Coerentemente com o método psicanalítico, aplicamos instrumentos que acreditamos pertinentes e necessários para obtermos elementos que nos conduzissem aos objetivos da pesquisa.

Com as entrevistas semidirigidas, pretendemos delimitar alguns temas de pesquisa que julgamos fundamentais e também dar às participantes alguma liberdade durante os encontros, de forma a garantir que o campo das entrevistas se configurasse por suas características de personalidade (Bleger, 1985). Nessa perspectiva e aplicando a psicanálise como fundamento, podíamos também 
conhecê-las melhor. As entrevistas semidirigidas dão ao entrevistado certa liberdade para expor questões e, ao entrevistador, a possibilidade de intervir para esclarecer pontos importantes (Ocampo, 1979). No presente caso, ao falar sobre tais pontos, acreditamos que ter tido acesso a elementos preciosos da dinâmica psíquica das participantes frente à maternidade e do impacto da vinda de um filho em seu psiquismo. Em princípio, essas entrevistas se limitam a desnudar questões relativas à maternidade e suas reverberações, mas acreditamos serem capazes também de fornecer elementos mais amplos da dinâmica das entrevistadas.

De acordo com Bleger (1985, p. 13), a entrevista psicológica é uma relação humana particular, na qual um dos integrantes deve procurar saber o que está acontecendo e deve atuar segundo esse conhecimento: "A realização dos objetivos possíveis da entrevista (investigação, diagnóstico, orientação etc.) depende desse saber e da atuação de acordo com esse saber".

Assim, consideramos a entrevista esse instrumento privilegiado de acesso à dinâmica psíquica das participantes, pois pode oferecer um horizonte amplo de elementos dessa dinâmica não só a partir daquilo que a entrevistada diz textualmente e de seu conteúdo inconsciente, mas também da forma como o diz, do que escolhe dizer, da maneira como acolhe a entrevistadora, do caminho que percorre para falar sobre cada tema e do impacto em nós daquilo que nos afeta nesse encontro, para mencionar apenas algumas das questões que as entrevistas podem suscitar no universo da pesquisa.

A escolha desse instrumento privilegia a possibilidade de o entrevistado configurar em grande medida o campo da entrevista a partir de suas próprias variáveis psíquicas, e a flexibilidade do entrevistador, aliada a seu compromisso de não matizá-lo demasiadamente com suas próprias condições (Bleger, 1985), Ihe permitirá uma escuta a partir da qual conhecerá seu sujeito.

A regra básica já não consiste em obter dados completos da vida total de uma pessoa, mas em obter dados completos de seu comportamento total no decorrer da entrevista. Esse comportamento total inclui o que recolheremos aplicando nossa função de escutar, porém também nossa função de vivenciar e observar, de tal maneira que ficam incluídas as três áreas do comportamento do entrevistado (Bleger, 1985, p. 13). 
Nesses termos, a entrevista é um instrumento importante; uma porta de entrada ao psiquismo daquela que queremos conhecer para elucidar como maneja seus recursos psíquicos quando espera um filho e como elabora a chegada dessa criança em sua vida.

A partir da análise das entrevistas e considerando todos esses aspectos, acreditamos ter verificado satisfatoriamente a forma como se foi configurando a relação de cada dupla mãe-bebê e os estados psíquicos de cada mãe após o parto. 


\section{capítulo 5}

\section{Reflexões e síntese das entrevistas}

Neste capítulo, analiso e reflito sobre o material de pesquisa recolhido ao longo dos encontros que tive com cada uma das participantes da pesquisa.

Tendo em conta que, mesmo cuidadoso, meu olhar é recorte do que pude captar e pensar nessas entrevistas, procuro refletir sobre o tema a partir de pontos relevantes que surgiram nos próprios encontros.

Para orientar a leitura, sistematizei alguns dados encontrados durante a análise do material na forma de quadros-resumo de cada um dos encontros com as participantes. Essa síntese se encontra no final do capítulo.

Respeitando a especificidade de cada caso, analisei mais profundamente duas participantes, Isabela e Érika, representantes de diferentes possibilidades de acolher e processar os impactos da vinda de um filho no psiquismo materno.

A título de complementação, apresento mais brevemente as entrevistas das outras três participantes do estudo, Gabriela, Vanessa e Carla, embora me tenham revelado um material tão rico quanto o das outras duas.

Posteriormente, analiso o material no todo, a fim de encontrar confluências entre os casos e construir uma discussão e uma síntese.

\section{ISABELA}

Isabela foi encaminhada por uma ginecologista-obstetra para integrar a pesquisa. Em nosso primeiro encontro, estava na $28^{\text {a }}$ semana de gestação. Primeiramente, o contato telefônico com ela foi bastante agradável. Ela me ligou e, enquanto que eu Ihe explicava como seria a pesquisa, esclarecia as questões éticas, sua colaboração sem ônus etc. Ela se mostrou muito acessível e interessada e confirmou que gostaria de colaborar com a pesquisa; completou dizendo que achava a proposta "muito bacana". Nem mesmo o fato de eu ter de vê-la logo na primeira 
semana depois do parto lhe pareceu inoportuno: me ofereceu visitá-la na maternidade, se eu quisesse. Parecia muito disposta e aberta ao contato comigo.

\section{ENCONTRO GESTACIONAL}

\section{Construindo a relação: o longo percurso do tornar-se mãe}

Tão logo nos sentamos, Isabela começa a entrevista. É ela quem parece querer me conhecer primeiro, antes de eu perguntar qualquer coisa. Faz perguntas gerais sobre minha formação e meu trabalho como psicóloga; eu respondo e entendo que ela não só quer saber um pouco sobre mim e meu trabalho, já que não me conhece, como tem o direito de saber.

Sobre a gestação, ela conta que queria engravidar havia algum tempo, desde que fez 30 anos. Parece dizer que fez uma espécie de reavaliação da vida e concluiu que foi quando surgiu a verdadeira vontade de ser mãe. Após esse marco, precisou adiar o plano algumas vezes, em função de sua realidade naquele momento: estava desempregada e pensou que não seria a melhor época para ter um filho; por prezar sua independência financeira, não gostaria de se tornar dependente do marido. Ao avaliar se era uma boa oportunidade para tentar engravidar, pensou na possibilidade de aproveitar o fato de estar sem trabalhar, mas ponderou que não seria uma boa alternativa. Mais tarde, pensei que essa escolha poderia ser considerada um indicativo do lugar do filho em sua vida. Ele podia ser importante, mas não estava necessariamente destinado a tamponar nenhuma angústia, nenhuma falta, com seu papel central. Isabela sentiu uma falta brutal de seu trabalho, significada por ela como desencadeadora de um quadro depressivo pelo qual foi medicada por cerca de seis meses, e passou por um processo terapêutico que durou em torno de um ano e parece ter sido relevante para ela.

Isabela conta com detalhes como foi o período anterior à gestação e como teve que adiar o plano de ter filho, primeiro, pelo desemprego, depois por causa do novo emprego. Esperou fazer um ano na empresa, mas, passado esse ano, sua chefe engravidou, e ela achou que deveria esperar mais. Quando finalmente pensou que era a hora propícia, ela demorou cerca de sete a oito meses para engravidar. A 
participante parece indicar como transcorreu o adiamento de seu projeto - e talvez suas perdas - no período pré-gestacional e mostra que esse período pode ser muito marcante e talvez angustiante para quem planeja engravidar; pode indicar também como podem ser o percurso e o processamento das perdas no horizonte materno:

\begin{abstract}
Ah, é um período complicado, né?, porque é muito cheio de ansiedade. Você fica esperando: ah, e agora, será que a menstruação vem? Aquela expectativa... Então, ao mesmo tempo, é um período em que você sabe que vai ter que estar tranquila pra que isso aconteça e tal... Todo mundo diz que você tem que desencanar, mas não é fácil; todo mundo diz "fica tranquila, que acontece", "fica tranquila, que acontece". Eu fui tentando, e nada, e nada...
\end{abstract}

Quando seu médico começou a fazer exames para verificar se Isabela tinha algum problema que a impedia de engravidar, foi detectado um nódulo no ovário. Conta que sua preocupação deixou de ser a gravidez e passou a ser aquele nódulo e a necessidade de fazer uma cirurgia. Dois dias depois da noticia de que se submeteria a uma cirurgia para retirar o nódulo, descobriu que estava grávida.

Ela passou da preocupação à alegria e novamente a outra preocupação: estava grávida de gêmeos. Na sétima semana, a ultrassonografia mostrou um segundo feto, menor e com indicativo de alguma anomalia, o que levou o médico, especialista em medicina fetal, a mencionar a possibilidade de abortar esse feto, pois, se continuasse vivo, ele poderia vir a prejudicar o outro, que se desenvolvia normalmente.

Isabela conta esse episódio com pesar e diz que passou uma semana de "horror", pela possibilidade de ter que fazer um aborto e pela preocupação com o risco que poderia correr o feto que se desenvolvia normalmente. Na oitava semana, o coração do feto anômalo parou de bater, o que ela conta com um misto de alívio e pesar. Alívio porque não precisou passar por nenhum exame ou procedimento mais invasivo, pois o feto teve um aborto natural, e tristeza pela perda intrauterina, que ela própria classifica como um "momento de luto".

Pensei que, realmente, antes mesmo de o bebê nascer, ela teve que elaborar a morte do feto anômalo. Mas, já nesse primeiro momento da entrevista, Isabela dá provas de que as experiências podem ter pelo menos dois lados: ela pôde considerar o alívio de não ter que "matar um filho" e a dor de não ter podido tê-lo. E, 
ainda, a de uma necessária capacidade de vinculação ao bebê que vivia em seu ventre, pois este sim precisava de seus investimentos.

Assim, logo no início da gestação, ela passou por uma prova de fogo: teve que lidar com uma perda concreta. Talvez o bebê que vive tenha sido uma espécie de alento para lidar com a perda e a elaboração do luto pelo feto que não se desenvolveu apropriadamente. Ela passa a investir no bebê vivo: faz o enxoval, prepara seu quarto, mas diz algo como "um teria 'cutucado' e dito ao outro: 'deixa eu ficar, sai pra lá!”. É importante destacar sua capacidade de cumprir esse árduo processo psíquico.

Isabela vai mostrando que sua vivência das perdas provocou tristeza, mas não a impediu de investir no bebê saudável e, ao mesmo tempo, na constituição do vínculo com o bebê e com seu papel materno. Assim, ela dá indícios de que é capaz de realizar o difícil trabalho psíquico de elaboração da perda do bebê que não se desenvolve apropriadamente:

\begin{abstract}
[...] vir dois! Nossa! Vou ter dois nenês, né?... Puxa, vai ser trabalhoso, mas também vai ser legal, porque aí eu já tenho de uma vez só, e não tenho mais filhos, já posso fechar... a porteira [risos], como dizem... mas assim... Passam várias coisas pela sua cabeça. Acho que é um pouco isso: esse mix de tristeza, de pesar e de alívio ao mesmo tempo... que a natureza se incumbiu de tomar... de resolver a situação por ela mesma, né? Por que, se eu tivesse que fazer um aborto, aí eu ia morrer, né? Já que ele parou naturalmente de se desenvolver, eu acho que foi um caminho... E parou cedo, parou na oitava semana; assim, parou num estágio bom, né? Num tempo de não... Quanto mais o ser humanozinho vai crescendo, mais gente vai ficando, se vê lá o coraçãozinho se desenvolvendo, se vê a mãozinha, se vê... Aí, ele parou de se desenvolver quando ele ainda era um feijãozinho [...]
\end{abstract}

Isabela conta que, quanto mais cresce seu bebê no ventre, mais se liga a ele. Parece falar sobre a construção paulatina do vínculo com o filho, sobre a possibilidade de construir a parentalidade em função desse vínculo que se estreita e da necessidade de desinvestir do outro feto para continuar a construir o vínculo com aquele que vive. Talvez esse luto pelo feto que não se desenvolveu adequadamente Ihe tenha permitido investir no bebê que vive e nela própria como mãe.

Com isso, notei que Isabela faz certas antecipações sobre o bebê que está por vir; uma delas é sobre ser mãe e profissional ao mesmo tempo: 
Como vai ser minha carreira com um filho, né? Então, eu tô assim... Como vai ser ser mãe? Ao mesmo tempo em que eu não quero que um filho atrapalhe a carreira, também não quero que a carreira atrapalhe a questão de eu ser mãe, de ser uma boa mãe. Agora, eu tô numa fase dessa coisa da carreira, do filho, de tudo isso que vem junto.

Isabela pôde exprimir com clareza o quanto fica dividida entre os investimentos na carreira e nela como mãe:

[...] ao mesmo tempo, eu quero ser uma boa mãe e também não quero ficar estagnada na carreira, onde eu estou [...] então, eu me sinto motivada quando eu tô vendo que eu tô pra frente, que eu tô fazendo uma coisa de que eu gosto, que dá resultado, que eu vejo resultado, e aí, se... Eu tenho certeza de que, se eu estagnar, eu não vou ficar feliz também, mas, por outro lado, também, até onde eu quero ir é o ponto, porque tudo tem um preço: quanto mais pra cima você vai, mais responsabilidade, mais preocupação, mais horas você tem que se dedicar. Eu também não quero me dedicar mais do que eu já me dedico, porque eu vou ter um filho, né? Eu quero ser uma boa mãe, eu quero estar presente, então, cê fica... Agora, eu tô naquela fase, né? Sempre é um conflito, né? A gente nunca tá feliz. Todo mundo assim: "curte seu nenêe!". Eu tô curtindo, tô curtindo... [risos]

O encontro com Isabela mostra como o dinamismo da vida se fez presente também no momento da entrevista, com suas curvas ascendentes e descendentes, como ela nos conta desses altos e baixos e como pode experimentar todo esse movimento em torno do percurso de ter um filho. Parece ter sido um longo caminho para engravidar, um trajeto pontuado por adiamentos, preocupações, perdas e lutos, bem como por realizações e alegrias.

Minha experiência nessa entrevista parecia uma viagem numa montanha-russa, deslizando entre aclives e declives, na qual parece que Isabela me levou junto consigo, me contando suas experiências e como as vivenciou. Ela expressa a possibilidade de entrar em contato com cada uma delas, sem se afastar da dor desencadeada por algumas.

Cerca de 25 dias depois da primeira entrevista, Isabela deixou um recado na secretaria eletrônica dizendo que estava em repouso porque corria o risco de ter um parto prematuro. Ela acreditava que teríamos que antecipar o encontro seguinte, que estava marcado para dali a duas semanas. (No recado, dá seu nome e se diz minha paciente.) Marcamos um horário para logo depois do telefonema que tivemos. 
Isabela me recebe em sua casa e conta que começou a sentir fortes dores após uma viagem de carro, a trabalho, que demorou três horas. Quando se levantou, nem conseguia andar, devido à dor que sentira. Depois do exame médico, soube que estava com encurtamento do colo do útero, o que lhe impunha repouso absoluto, para evitar um parto prematuro. Preocupava-se sobretudo com o risco de ter um bebê prematuro e precisar se afastar do trabalho mais cedo do que esperava:

Eu tenho muitas preocupações. A primeira é segurar esse nenê até 36 semanas pelo menos... Estou na $33^{a}$, mais três semanas... A segunda é aquela questão do trabalho, porque a empresa está passando por uma fase muito difícil [...] está me desmotivando muito lá dentro. Então, você fica pensando "acho que eu vou procurar emprego durante a licença maternidade", sabe essas coisas?... Por outro lado, é uma empresa. Por enquanto - a gente não sabe como vai ficar -, mas, por enquanto, eu tinha uma flexibilidade... o pessoal entra às oito e sai às cinco; não é que nem aquelas outras empresas em que você fica até tarde trabalhando. Enfim, tem várias preocupações, que a gente sabe que não tem que se preocupar agora, que é uma coisa por vez...

Isabela diz que, apesar dos receios e das dúvidas, pode contar com algumas ajudas: parece sentir que pode confiar em sua chefe, sua mãe está em sua casa durante o repouso, para ajudá-la; ela contratou uma empregada para ajudar com a casa e com o bebê, quando ele nascer. Fundamentalmente, Isabela parece ser alguém que aceita ser ajudada e amparada nesse momento, tal como sinto seu movimento em relação a mim.

Ela também conta como percebe nesse momento que sua vida sofrerá uma mudança importante, de que decorrerão rupturas e as necessárias adaptações. Parece dizer também sobre a consequente antecipação do bebê e a paulatina construção do vínculo com ele, que já aparecia no momento da primeira entrevista:

[...] aí, cê vai vendo a evolução, pega a primeira fotinho, tá muito magrinho, não parece com ninguém; na segunda fotinho, cê já acha que começa a parecer, e, nessa última, já tão as feições... tudo, né? cê já vê que dá pra identificar com quem se parece - é muito legal... parece com o (nome do marido), parece, sim... é muito gostoso, né?... preocupa, é uma preocupação pra vida inteira, agora, o bem-estar do nenê, acho que vai... várias coisas eu acho que vão ser pra vida inteira: a preocupação com teu filho, né? nunca mais é você, só você, você e o... a preocupação com seu bem-estar, com o bem-estar do teu marido e acabou... agora, tem outra pessoa pra se preocupar e também tem toda uma adaptação, né? porque o casamento todo mundo fala - muda. Então, tem que se policiar pra não ficar cem por cento com o nenê e continuar sendo mulher, mãe, esposa e tudo... Eu tenho que tirar essa expectativa de que não dá pra ser boa em tudo então, sei lá, 
casa... alguma coisa vai ficar pra trás: ou é a casa, que não vai ficar organizada, bem limpa, que vai faltar coisa de supermercado, ou que é... e que sejam coisas da casa, e não coisas nem pro teu marido e pro teu filho...

Isabela procura antecipar sua vida com um filho daí em diante, numa tentativa de ir se preparando para as mudanças que acarretará a chegada do bebê, em breve, inclusive em seu funcionamento psíquico, que vinha já se transformando. Sua fala também pressupõe que o filho não é, como eu presumira, destinado a preencher tudo em sua vida; ele é importante, ela lhe reserva um lugar de destaque, mas também ao marido e ao trabalho. E parece também querer se preparar para a necessária redução da expectativa de que tudo terá que sair perfeito, de que nada faltará ou falhará.

É interessante perceber que Isabela pondera a todo o momento os vários lados desses acontecimentos, com as limitações de seu atual estado e após o nascimento do bebê. Ela conta a experiência de sua chefe, que, já com outro filho, havia percebido que passara todo o sofrimento que tinha vivido com o primeiro e agora podia aproveitar muito mais a vinda do segundo. A esse respeito, diz Isabela: "Por mais que as pessoas falem pra gente, experiência não se passa. Você pode ler milhares de livros, milhares de cursos, e não sei o quê [...]".

Parece-me que ela vai aproveitando o encontro para pensar e estar junto comigo. Lembro-me do recado em minha secretaria eletrônica, em que ela se apresentou como minha paciente, talvez representativo de seu movimento transferencial. Parece fazer uso do espaço da entrevista para pensar sobre alguns medos e expectativas frente ao encontro com $\mathrm{o}$ bebê e a experiência da maternidade, bem como sobre as mudanças por que passará. Um exemplo disso é sua fala a respeito do parto:

[...] outro medo que me veio quando veio a história do parto prematuro: comecei a pensar no parto; é outro medo que a gente tem. Ai, meu Deus, será que eu vou conseguir parto normal? E a dor? Não quero ir pra cesárea direto porque a gente sabe que é melhor pro nenê, o parto normal, e a cesárea, fica sei lá quantos meses sem fazer um exercício, sem poder carregar peso. Parto normal é tão mais fácil. Começam a vir milhões de coisas, mas veio tudo de uma vez, porque eu tô com sete meses pela frente ainda. Eu fui na médica, ela [me] assustou realmente. Ela falou "fica de repouso". Voltei depois de quatro dias - tinha diminuído mais ainda. "Você fica de repouso absoluto, deitada. Não quero você nem sentada: toma banho e deita. Vamos dar injeção pro pulmãozinho do nenê. Aí eu desesperei: eu vi que o negocio era feio mesmo. Aí veio essa enxurrada: ai, meu Deus, parto 
prematuro, nenê prematuro, a dor do parto, não sei o que, o trabalho... Agora, já passou.

Sobre como imagina seu bebê, diz Isabela:

Eu não tenho muitas expectativas de "ah, eu acho que meu filho vai ser assim, assado, acho que vai ser assim, bonito, feio, calmo, bravo". Procuro não ficar esperando. No fim das contas, não vai ser nada do que a gente planejou, não é? [risos]

Em alguns momentos, me pede uma postura mais direta e prossegue:

Meu filho vai ser calminho, vai dormir a noite inteira, vai ficar parecido comigo, que chorava a noite inteira. Ah, minha preocupação normal - maior - quando começo [a pensar no] parto prematuro é o tamanhozinho dele. Ai, é uma criança que vai requerer mais trabalho, vai requerer mais cuidado, né? $O$ quanto é esse mais cuidado, ao ponto de você não exagerar, fazer a criança - porque eu vejo um monte de mãe que, pra pegar a criança, tem que passar álcool na mão, esterilizar tudo e não sei mais o quê -, enfim... No fim, sai, a criança fica mais doente ainda. Tanto que depois saiu até uma reportagem falando - não sei você viu [...] - que tem feito algumas experiências com ratos que foram criados filhotinhos num ambiente onde tudo era esterilizado, assepsia total e outros que não, que foram criados com grau de vitamina $S$ [risos]. e os que foram criados com vitamina $S$ eram mais saudáveis do que os outros. Não adiantava você expor depois de um tempo, já quando tava maiorzinho, às bactérias e tal. Tinha que ter feito isso quando era recém-nascido, quando era pequeninho. Então, tudo o que é demais é veneno, né?

Parece também falar sobre o que espera de seu filho e um pouco de si mesma, como mãe:

[...] o pessoal fala assim: "prematuro é tudo peralta, é tudo... deve ser porque é tão mimado, todo mimado fica peralta... tem que tomar cuidado pra não mimar demais, eu odeio criança mimada". [risos] Isso eu não quero, ele é o primeiro neto dos dois lados, ainda, e eu não quero uma criança mimada. Primeiro, que criança mimada acaba sofrendo mais. É que o mundo não é assim. A criança mimada, quando vai pra fora, acaba apanhando mais, começa ver o mundo fora do ambiente dos pais, começa a apanhar mais ainda. O bem que você achava que estava fazendo acaba fazendo mal, você tem que... tanta coisa, né? A gente - todo mundo fala: "só tenha a certeza de que você vai errar, o resto...".

No fim da entrevista, Isabela me pergunta se tenho algum conselho para lhe dar. Houve um movimento interessante, pelo qual pareceu que ela foi aproveitando o encontro comigo para ir também se preparando para o encontro com o bebê e com o desconhecido dessa experiência. Sua angústia sofreu uma mudança expressiva ao longo da hora que passamos juntas: parecia bem alta, no começo, mas, depois que 
ela tratou dos temas que a preocupavam, seu estado emocional melhorou sensivelmente. Especialmente importante pareceu ser a possibilidade de compreender o repouso que se viu obrigada a fazer como uma forma de se preparar para receber seu filho, podendo dar um sentido à experiência angustiante.

\section{PRIMEIRO ENCONTRO APÓS O PARTO}

\section{Sobre as dores e os amores...}

Encontrei-me com Isabela uma semana após o nascimento de seu filho. A primeira coisa que me disse foi sobre o parto - ela não teve coragem de ter parto normal, com medo do corte da episiotomia, pois, algumas pessoas the haviam dito que a dor decorrente desse corte era pior do que o da cesárea em si. Seu plano era esperar, não ter que optar pela cesárea antes de o bebê sinalizar que estava pronto, e foi isso que aconteceu. Pareceu-me significativo o fato de o bebê não ter nascido prematuro, como se temia a princípio. Com 36 semanas de gestação, Isabela foi liberada por sua médica para sair do repouso absoluto, mas optou por não voltar a trabalhar, uma vez que já estava de licença médica, e havia uma organização já instalada. Nesse momento, ela consegue deixar o investimento no trabalho para se concentrar na espera do filho.

Falando sobre seus receios e suas dores, Isabela conta como tem repensado constantemente o projeto anterior, adequando-o às exigências da maternidade real, e como com a concretude da experiência e a vinda do bebê na realidade exige trabalho psíquico para processar as situações novíssimas e seu forte impacto. A esse respeito, foi emblemática a dor que sentiu nos primeiros dias: as rachaduras nos bicos dos seios e o ingurgitamento mamário pegaram-na desprevenida; ela imaginava a dor do parto, mas não esperava a dos seios, que viveu intensamente:

Rachou o bico, empedrou, né? Então, nossa! Era uma dor... aguda, né? Não sei se você chegou a passar por isso, mas é uma dor com que eu não tava contando, esperando por ela, sabe? E isso me abalou muito: aquele seio todo empedrado, e eu não conseguia dar de mamar, né? Botava o M. pra mamar, eu chorava quando dava de mamar. 
A dor no seio desencadeou um transtorno muito grande em Isabela e fê-la se perguntar se conseguiria levar adiante o projeto inicial de amamentar o filho:

Ele pegou muito bem, nasceu sabendo mamar, tanto que eu não achei que fosse ter problema com o seio, porque ele veio superbem, ele foi superfácil; ele pegar foi facinho, foi tranquilo. As enfermeiras ficaram bobas de ver, ele pega muito bem, e é muito legal, né? Cê botar pra... no começo, quando eu não sentia dor, achei um momento muito mágico, o nenê ali, você dando de mamar, eu achei muito bonito, até que comecei a sentir dor, né? Comecei a sentir dor, o peito começou a rachar; no segundo dia, o bico já começou a rachar; aí, no terceiro dia, quando recebi alta, já tava todo ferrado: além do bico rachado, [o leite] empedrou. É uma dor horrível, né? Aí, fiquei cuidando. Quando trazia ele pra mamar, eu chorava de dor e cheguei a pensar "será que eu vou conseguir?". Mas [...] é muito importante, não passou pela minha cabeça "eu vou parar, não vou dar mamar pra ele", né? Não pensei isso, mas quanto tempo será que eu vou ficar sofrendo desse jeito? Eu não conseguia nem curtir ele, e a casa cheia, todo mundo comemorando, e você falando de dor, né? É um horror, o pessoal todo feliz, e você lá, não conseguindo curtir de tanta dor [...].

Com a tentativa de se preparar bem para a experiência da maternidade, Isabela pôde evitar a dor do parto, mas não logrou escapar das outras dores, com as quais não contava e lhe produziram um choque. Na época da entrevista, ela havia conseguido encontrar um modo de as dores no seio melhorarem e voltou a sentir prazer em amamentar o filho.

Ao longo de todo o encontro comigo, Isabela falou sobre suas dores e seus amores... Depois, ao dizer do susto e do impacto decorrente dessa dor para a qual não se preparara, disse também da emoção indescritível sentida quando ouviu o choro de seu filho ao nascer e de como, por um instante, não acreditou que ele tivesse saído de seu ventre. Parece sempre se remeter aos vários lados que pode ter cada experiência.

O parto foi tranquilo, sua médica lhe deu segurança e seu marido a acompanhou e, como ela, se emocionou muito. E é emocionada quando ela conta o momento do nascimento do filho: "[...] é mágico... é uma coisa que não dá pra explicar, não dá pra falar em palavras, acho que é o momento mais lindo que eu já passei na minha vida! Foi emocionante... tô chorona...”.

Ao longo do encontro, Isabela fez uma espécie de inventário das perdas e dos ganhos da experiência e observa que, apesar de planejado, seu bebê porta um excesso: seu nascimento foi acompanhado de um susto, e parece mostrar que não 
há preparação que dê conta da vinda de um filho no horizonte materno, mesmo como nesse caso - se tratando de um filho planejado e desejado, e ainda contando com a antecipação do bebê, feita na gestação, e de seu lugar materno.

O susto decorrente do nascimento reverberou na dinâmica não só da mãe, mas também do pai, segundo me contou. Ela diz que ele ficou "transtornado", que ele enlouqueceu: "Quem pirou foi o meu marido. É impressionante como ele pirou com a chegada do nenê. Começou a querer controlar tudo [...]. Ele surtou porque mudou, ficou uma pessoa [como] um leão de chácara, querendo controlar tudo, as pessoas, o que se ia fazer com o nenê, o que não ia...”.

Os impactos foram sentidos como abalos no equilíbrio dinâmico do casal e de cada um em particular, mas fundamentalmente parece haver uma interferência no campo do outro. Isabela conta como foi surpreendida por mais esse vetor. "É eu não esperava essa... Ele ficou transtornado... Não sei se ele não estava preparado, é que... Sabe o que é? Ele nunca teve um nenê na família, né? Não sabe como é ter um nenê, então... tudo pra ele é muito novo..." Ela consegue avaliar que, para ele, também pode ser difícil e, tentando entendê-lo, diz que está preocupado com sua situação no trabalho, agravada pela pressão de agora ser "chefe de família": "Mas, pra mim, o mais difícil foi o seio. É teu corpo, né? Quando cê tira o nenê, cê continuou com aquela barriga. O corpo, cê vê que muda e tal...”.

Isabela enfatiza o que lhe pareceu mais penoso na experiência: a vivência no corpo, a dor representada no corpo, da qual não há preparação que dê conta.Talvez possamos pensar que seja pela transformação de mulher em mãe e das perdas e exigências que daí decorrem. Ela continua me dizendo que viveu os primeiros momentos como puro excesso, mas consegue, a despeito disso, sentir e viver a outra face da moeda, como foi afetada agradavelmente pela vivência de ter um filho:

Fui prestar atenção nisso há uns dois dias atrás, no começo é tanta coisa, né? Que cê nem dá bola pra isso, mas aí depois que eu cheguei em casa tal eu comecei a olhar, eu falei gente! Que estrago que faz ... que é ter um filho, quanto...tudo que muda, né? Na sua vida, então eu falei o negocio é feio, o negócio não é fácil não... [risos].

Ao contar sobre as reverberações das dores no pós-parto, nos diz como respondia a elas: uma das formas foi chorar: "É, a gente fica muito emotiva, né? 
Muito... mas... principalmente no... acho que na primeira semana, agora, não... mas eu choro com facilidade". Quando o bebê mamava, ela chorava de dor, e havia uma pressão vivida como brutal:

Mas é difícil, né? Esses três primeiros dias de hospital... Acho que os hormônios dão uma baixada. Lá, teve um dia em que eu vi que eu tava bem mal, mal no sentido de... Nossa, como mudou, como... Não sei explicar, mas essa sensação do... tá sendo mais difícil do que eu imaginava, por causa da questão física. Acho que parto normal tem essa vantagem, porque você tem mais destreza para lidar com seu filho, não tá com os movimentos limitados, porque, além de tudo, além da falta de experiência de pegar, de lidar com o nenê e tal, cê não consegue sentar direito, não consegue andar direito, não consegue amamentar direito. Então, [tem] aquele monte de limitações, e você não se permite estar com aquela coisa... restrita, porque você tem que ter saúde pra cuidar, tem que ter... [dá] uma sensação de impotência [...[. É, mas acho que tudo isso tava ligado com a baixa hormonal. Você dá aquela... eu queria chegar em casa e ficar sozinha. Sabe quando cê queria entrar dentro de um casulo e não sair de lá? Você e seu bebê. Sozinha, não. Você e o bebê. Não queria mais ninguém, sabe? Essa era a sensação que eu tinha. Aí, eu fiquei sozinha. Era isso que eu queria. Tinha esse sentimento, mas passou. Agora, tá tudo bem.

Fundamental parece ser a urgência da responsabilidade de cuidar, o que entendemos como a transição para a parentalidade:

[...] eu ouvi ele chorar, conheci o choro dele lá no berçário, aí, eu levantei... Em casa, é aquela responsabilidade, eu fiquei com medo... Meu maior medo foi dormir e [ele] se afogar com os paninhos, ele passar frio (tava muito frio). Então, ele dormiu no bercinho lá comigo, e eu ficava olhando pra carinha dele. Nem dormi direito, para ver se tava respirando... se tava tudo bem, a noite inteira. Ele dormiu no meu quarto na primeira noite.

Isabela conta como a percepção do desamparo do bebê a faz suplantar seu próprio desamparo, suas dores, as mudanças sofridas e o impacto da presença desse outro em seu horizonte - seu filho dentro de sua própria vida: "Muda toda a sua rotina: cê não dorme, cê é outra pessoa, cê vive pro nenê. E o pior: cê olha a carinha dele, compensa tudo, né? Cê olha o rostinho dele, os olhinhos dele, nem reclama, né?" É um outro que, apesar de ser parcialmente um estranho, porta um conhecido, e é no olhar assustado de seu filho que ela se reconhece mãe; também um pouco assustada, mas consegue oferecer-Ihe aconchego e amparo, tolerando 0 "estrago" significado no corpo e o fato de ser outra pessoa que ela ainda não sabe ao certo qual. No entanto, fundamentalmente, ela parece usar de sua própria vivência de desamparo, de choque e de ameaça para fazer seu filho viver, apesar de toda a dor. Talvez o desamparo possa ter sido representado por ela justamente 
pelas dores e pelos impactos sentidos, pela falta de preparo, apesar da tentativa de se preparar minimamente para a vinda de seu filho. Penso que a possibilidade de reservar em seu psiquismo um lugar como mãe e um para seu filho e uma capacidade interna de ir entrando em contato com todas essas questões pode favorecer o entristecimento de Isabela, mas sem sucumbir a ele.

Suponho que é na tessitura dessas tramas que Isabela vai construindo, além do vínculo com o bebê, que se tornou real com o advento do parto, os alicerces da parentalidade. Ela parece se apoiar na possibilidade de ir transformando em algo a mais cada momento, a aparente simplicidade rotineira de seus cuidados e a percepção do "olhinho assustado" do filho. Vai experimentando o que o bebê precisa, por estar vivamente conectada com ele; vai testando uma melhor forma, ou uma maneira possível de cuidados, supondo-se uma mãe falível, que está aprendendo, suportando estar no lugar de aprendiz: "a gente acaba errando com ele, tadinho. É nossa cobaia, né? Então, a fralda que não coloca direito e vaza, o banho que podia ser de dez minutos, dura vinte [risos], e assim vai... Tadinho".

$\mathrm{Na}$ impossibilidade de saber tudo, ela se curva à experiência de maternar, investe em seu bebê, oferecendo-lhe seu narcisismo transvasado para ampará-lo e fazê-lo viver.

Então, é hora de conhecer, de conhecer o nenê: do que ele gosta, no que se encaixa melhor, todas as rotinas, todas as recomendações e tal. Como é que ele se adapta melhor: se troca a fralda entre uma mamada e outra, se troca a fralda no fim, né? Como é que é melhor, tal... Ah, descobrir qual é o choro de fome e quais são os gestos dele quando ele tá com fome. É um barato, assim... é uma descoberta todo dia!

Também foram fundamentais a presença verdadeira e o suporte emocional respeitoso oferecido por sua mãe, amparando-a na tarefa de construção de sua própria capacidade de parentalização, numa espécie de holding do holding materno:

Minha mãe aqui foi fundamental pra ajudar, né? Deixa a gente mais tranquila... Tem sido tranquilo, porque ela tá. Minha mãe é uma pessoa assim... que... maravilhosa, minha mãe é uma pessoa que... que ela prefere se afastar, ao invés de se intrometer [...]. Minha mãe falou "eu vou ficar até você estar boa". É engraçado: depois do parto, todo mundo fica preocupado com o nenê, a sua mãe é a única pessoa que está preocupada, além do nenê, com você. Então, ela tava cuidando de mim... 
É no contato com a dor, suportada pela presença de alguém que a ampara, que ela pode também experimentar o amor!

Isabela sempre me inclui no encontro, pedindo minha participação ativa.

\section{SEGUNDO ENCONTRO APÓS O PARTO}

\section{Sobre perdas e ganhos}

Nessa oportunidade, Isabela exprime a transformação que a maternidade e a parentalidade provocaram em sua vida. Conta como vive intensamente a presença do filho, bem como a perda que considera maior, a da "liberdade de ir e vir", e como essa perda convive com um ganho imenso:

\section{[...] chegou o momento mais difícil pra mim: não é ficar sem dormir, é perder a liberdade de ir e vir, né? Cê não poder fazer as coisas que você precisa. Sei lá, preciso ir a uma farmácia, preciso comprar uma roupa, preciso sei lá... sair um pouco... Você não tem mais essa liberdade de ir e vir, você não consegue sair, você não consegue fazer essas coisas...}

Sua fala aponta as necessidades imperiosas do filho, principalmente por sua absoluta dependência, e o decorrente impacto no psiquismo materno, uma vez que ela conta que sua vida perde o centro: ela própria não é mais o centro, teve que abrir mão de um espaço psíquico dentro de si para oferecê-lo ao filho, para fazê-lo viver. No entanto, vai paulatinamente construindo um novo lugar. É emblemática sua fala sobre as roupas que não lhe servem mais: "porque eu não tinha roupa, nem roupa pra vestir, porque as roupas de antes da gravidez não servem, e as da gravidez também não servem [risos]... então, eu ficava com aquelas roupas horríveis; cê vai se sentindo mal, né? Cê fica se sentindo péssima...”.

Uma rede de suporte funcionando adequadamente parece ter sido decisiva para atenuar em Isabela os impactos da dor e do cansaço da tarefa de ser mãe. Ajudada pela própria mãe, ela pôde voltar a ter alguns cuidados consigo mesma, o que a fez sentir-se melhor, e, nutrida, pôde continuar a investir na relação com o filho, transvasando seu narcisismo e deslocando-o para ele:

[...] e, ao mesmo tempo, agora, a gente fica cada vez mais apaixonada pelo nenê, né? Agora, a gente vê a evolução dele dia a dia, umas coisas 
diferentes. Agora, ele começa a ficar mais um pouquinho acordado, aí, acho que tá tudo entrando nos eixos... Agora, já consegui dormir na mesma cama que meu marido [risos] - depois de cinco semanas [risos].

Ao mesmo tempo em que vai conhecendo cada vez melhor seu filho, vai diminuindo seu sentimento de estrangeira como mãe. Paralelamente a isso, seu marido vem aprendendo aos poucos a lidar com o bebê, e Isabela tolera esse aprendizado do pai remetendo-se a sua própria experiência de ser uma mãe apenas suficientemente boa, e não perfeita. No entanto, no que diz respeito aos cuidados e à ajuda da sogra, ela não transige: não a vê como alguém que a ajuda, mas como alguém que a deixa insegura. O contrário parece sentir sobre a pediatra que os está acompanhando; casualmente, descobriu ser uma pessoa próxima de um conhecido de sua mãe, e sente-se bem acompanhada por ela.

Isabela testemunha lindamente o caminho das perdas na maternidade dizendo de certa "insanidade materna" na decisão de ter um filho, pois a vida fica completamente transformada e transtornada, gerando uma constante preocupação com o bem-estar da criança. Entretanto, a essa demanda de trabalho físico e psíquico, soma-se o amor pelo bebê. É uma loucura ter um filho, deixar de ser dona de si e saber que a vida nunca mais vai ser a mesma!

É assim, né? É aquela preocupação constante com o bem-estar da criança. Onde eu estava com a cabeça quando disse que queria ter filho? [risos] Porque dá muito trabalho, né? Agora... Agora já foi, né? [risos] Agora tá aí, é uma paixão e tal, eu amo... muito! Mas... gente, é loucura isso! Eu falei: não quero ter o segundo, não! Todo mundo fala, cê vai esquecer! Daqui a dois anos, cê vai querer ter o segundo filho... Não vou, não... Não, porque cê tem toda uma vida, né? Que... que se faz o que você quer, na hora que você quer, sem preocupação. Agora, é uma preocupação constante, né? Não é mais dona de você, tem uma pessoa que depende de você, é uma coisa muito louca! É... Ao mesmo tempo, é... eu acho que é... são... duas faces totalmente diferentes: ao mesmo tempo que tem tudo isso, é um amor! É uma coisa assim que todo mundo tem que experimentar, uma emoção... não sei, é meio contraditório todo mundo fala "passa, vai passar, vai passar"... São vários sentimentos... [...] Não é só do físico, é emocional também... a vida da gente não vai mais ser a mesma... eu falava assim... eu falei pra minha mãe, vocês ficavam falando "quando que vai ter filho? Quando que vai ter filho? E não falam de todo esse trabalho que dá..." [risos]

A "insanidade materna" de que fala Isabela me parece ser o que chamamos de impacto decorrente da vinda de um filho no horizonte parental, para o qual não há preparação possível, posto que esse encontro com o bebê na realidade é sentido 
como um excesso pelo psiquismo materno e, muito provavelmente, pelo paterno também.

Isabela observa que a fase mais crítica ficou para trás e que ela se sente cada dia mais "apaixonada" pelo bebê. Suas conquistas, o fato de vê-lo engordando, crescendo e o prazer que sente na relação com ele engendram uma retroalimentação libidinal entre mãe e filho, na qual o prazer sentido volta em forma de cuidados prazerosos para ele, o que incrementa a relação, e assim reciprocamente.

Além de perceber as sutilezas das conquistas do bebê incrementando a confiança em seu papel materno, Isabela percebe que, sendo temporárias, algumas perdas são suportáveis. E eu vejo um deslocamento da parte dela: as questões não são as mesmas da última entrevista - há movimento na construção difícil mas prazerosa de sua parentalidade.

Suponho que Isabela vai percorrendo um caminho em que transforma algumas questões. Conta que, quando algo não está bem, discute com o marido a forma de melhorar, de não se sentir tão sobrecarregada pelos cuidados com o filho, convoca-o a ajudá-la, o inclui intensamente na relação com o bebê, e ele responde positivamente a essa proposta de inclusão. Ela parece dizer que vai tentando sempre "corrigir a rota", e que a construção da parentalidade tem sido tecida juntamente com o marido: "Porque não tô dando conta. Eu falei pra ele "eu tô ficando piradinha, tô muito cansada". Aí, a gente conversou [...]. Ele falou "tá bom", e ficou com a incumbência de... Então, a gente tá se acertando assim, e... acho que vai entrando nos eixos [risos]".

Acentua a vivência paradoxal que é a maternidade e como a amamentação pode ser sentida como um acréscimo à relação, quando experimentada como fonte de prazer, e não apenas como mera obrigação:

[...] ele tá mamando direitinho, ele tá engordando bastante, ele tá engordado 60 gramas por dia, e tá saudável e... ah... mamar, agora, tá começando a ficar gostoso, porque... agora, ele já tá olhando para você, já tá participando, já tá olhando, já tá dando risadinha... então, é muito gostoso! E, ao mesmo tempo que é uma dependência, que te amarra, porque cê não pode sair de casa porque tem que dar de mamar e tal, é... é uma dependência ruim e boa, porque é um momento seu e dele, né? É um momento que... aproxima mais.... que... ah, é muito gostoso! São dois sentimentos mesmo, porque, 
poxa, eu não posso sair de casa porque eu tenho que dar de mamar, outro, nossa, que gostoso dar de mamar! [risos]

O "manhês" 35 no diálogo entre mãe e filho se parece com o da amamentação. $\mathrm{Na}$ relação de Isabela com seu bebê, parece haver uma conversa recheada de prazer. Ela me convida não só a presenciar esse momento, como me introduz nesse diálogo.

Nosso encontro também parece privilegiado por Isabela. Ela cuida desse momento, que parece prazeroso para nós duas. Não deixa que a entrevista seja interrompida, me convoca, quer saber sobre meu trabalho de pesquisa e se tudo o que sente é normal, ao mesmo tempo em que acredita que sim.

Com Isabela, tive contato com todo $\mathrm{o}$ trabalho de transtornos $\mathrm{e}$ transformações que implica a construção da parentalidade e com o amor que ela sente pelo filho, decorrente dessa construção. A maternidade real inclui se dar conta das perdas, algumas irreversíveis, e elaborá-las. Talvez poder entrar em contato com essas inúmeras perdas e a tristeza que acarretam, ela tenha podido sentir também os ganhos. Seu filho nasceu, está bem, ela se reconhece como sua mãe, está em curso uma retroalimentação libidinal que a fortalece para corrigir a rota, quando necessário, e seguir em frente, apesar de tudo. As harmonias do encontro, os ritmos compassados, a possibilidade de corrigi-los quando há um descompasso, uma desafinação. Sua possibilidade de contar com apoio e suporte, ao mesmo tempo em que se deixa ajudar, o fato de contar com sua capacidade de entrar em contato com a experiência e de regredir e se deprimir parecem tê-la ajudado nessa tarefa.

\section{TERCEIRO ENCONTRO APÓS O PARTO}

\section{Sobre a importância dos ritmos}

O desenvolvimento do bebê retroalimenta a mãe libidinalmente cada vez mais. A evolução das conquistas do bebê fortalece a confiança de Isabela no papel

\footnotetext{
${ }^{35}$ Termo específico que designa a comunicação especial que as mães têm com seus bebês, numa prosódia marcada por modulações especiais da voz, que a tornam mais lenta e sonora, mais musical.
} 
materno, aumentando seu regozijo materno e seu amor pelo filho e fortalecendo o vínculo com ele. Ela percebe mudanças e entende que pode haver alterações:

Eu acho que a grande mudança, da época em que você veio pra cá, acho que o grande marco é quando ele começa a dar risada, a tentar se comunicar, a balbuciar. Nossa! Isso é de uma semana pra outra. Assim, já muda tudo, né? Aí, cê começa a ficar cada vez mais boba, mais apaixonada, né? Cada vez mais é... eu agradeço todo dia a Deus, sabe? Por ele ter vindo, tal...

Podendo perceber mudanças, ela também pode vivenciar as perdas, e parece que a capacidade de entrar em contato com elas e de elaborá-las que lhe permite admitir o ganho, o prazer com a vinda do filho, que pode ser nutrida por sua presença:

Cada vez mais... eu agradeço todo dia a Deus, sabe? Por ele ter vindo, tal... Já mudou aquela sensação do primeiro mês, aquela sensação de que... Nossa! O que que eu fiz com a minha vida? [risos] Tava tão bom, né? [risos] Cê fica com aquelas duas sensações: é meu filho, eu amo ele, mas minha vida, nossa! Cadê aquela vida que eu tinha? Aquela fase de transição, né? Agora já passou... Agora, a gente não consegue nem imaginar como seria nossa vida sem ele, né?

Penso que essa é a questão central: "O que é que eu fiz da minha vida?" Seria uma das representantes da tristeza puerperal, do blues materno, que Isabela ilustra de maneira brilhante, conseguindo se questionar profundamente sobre uma perda que ocorreu no horizonte materno - "onde está a vida que eu tinha antes?" - e a necessidade imperiosa de ter que fazer viver seu filho, que parece ser brutal para todas as mães no início da vida do bebê. Para Isabela também, mas ela parece conseguir entrar em contato e elaborar essa perda da vida anterior, talvez de parte de seu próprio narcisismo, que pode ser atenuado pelo ganho de prazer sentido com a presença da criança e com o fortalecimento do vínculo.

Refere-se a uma espécie de período de transição, do início do puerpério ao momento atual: o impacto da doação de parte de seu narcisismo para seu filho viver. Isso me leva a pensar que esse momento do pós-parto imediato pode ser representado como um rito de passagem, sucedido por uma identidade nascente.

Com a relação caminhando bem e com o bom desenvolvimento do bebê, Isabela pode abrir espaço para suas próprias necessidades - pensa em voltar a fazer ginástica. Parece perceber que seu filho responde aos investimentos maciços 
dos pais e que ele não precisa dela como antes: "Tô tranquila assim. Eu acho que mais... o que às vezes acontece é eu ficar um pouco entediada de ficar em casa, porque agora eu já tô me sentindo bem. Agora, eu quero ir fazer minha ginástica, então, eu já fui ver as aulas da hidroginástica...".

E ela lida assim com outras perdas, como as restrições alimentares para que o bebê não tenha cólicas:

\begin{abstract}
[...] depois que completa três meses, a médica falou também que a alimentação não precisa ser mais tão restrita, porque [ele] já tá acostumado... Foi um alívio. Eu não sabia. Achei que, enquanto estivesse amamentando, eu não poderia comer um monte de coisas. Ela falou "não, três meses"... Tô evitando leite, derivados de leite, porque ela achou que o refluxo e as coisas na pele dele pudessem ser rejeição à lactose. Então, eu cortei tudo o que é leite, iogurte, queijo - tudo o que eu adoro. Cortei. Isso me deixou muito mal, quando ela falou que era para cortar, porque cê já não come chocolate, não toma café, não come não sei o quê, não sei o quê... e leite. Em tudo vai leite... mas eu acho que não, porque agora, não tô mais tão... antes, cê fala "ah, uma pizza, na massa"... uma pizza sem queijo, mas na massa pode conter queijo. Agora, não tô nem aí... agora, não vou comer o leite em si, nem o queijo, mas num bolo tem leite, paciência! Tô comendo, e ele tá bem, melhorou bastante do refluxo...
\end{abstract}

É interessante que as falas que remetem às faltas e às perdas são pontuadas por falas sobre o amor que sente pelo filho, levando a pensar no quanto a perda muitas vezes momentânea - pode ser suportada pelos ganhos decorrentes da presença do bebê em sua vida:

Ela pediu pra segurar o leite até o terceiro mês. Mais uma semana, semana e meia, faz três meses. Não custa esperar um pouquinho... Eu tô nessa: faltam três semanas só, duas semanas [risos]... Contagem regressiva! Então, assim... com ele, tô cada dia mais apaixonada... a gente sente aquele amor que a gente fala que até dói, que te faz chorar... É um amor tão intenso que nossa! - te faz chorar, até... às vezes, eu abraço ele, à noite, e falo "meu Deus, que coisa maravilhosa!"

Seguir o pensamento de Isabela mostra que a todo instante ela pode ir contando com os acréscimos sem precisar negar ou se afastar veementemente daquilo que a preocupa ou da próxima perda:

Acho que o próximo drama é o desmame. Eu já tinha falado assim "não, quando ele completar três meses, na mamada da noite, eu já vou dar o [marca do leite]. Agora, ele tá completando três meses, eu tô repensando. Agora, eu vou jogar pro quarto: no quarto mês, eu começo a dar o [marca do leite]... porque... cê tem leite, né? Cê vê os seios cheios, cê não vai dar? A gente sabe que faz bem pra ele, né? 
Para Isabela, amamentar é uma experiência em grande parte prazerosa, no entanto, ela sente que seria melhor fazer uma amamentação mista, entre leite materno e leite em fórmula, para ter mais "independência", caso precise sair. Por outro lado, ela parece significar como uma perda o fato de deixar de amamentar seu filho:

\begin{abstract}
Ah, ela falou que atualmente podia dar o [marca do leite]... se precisasse... [mas que] devia dar de preferência tirar o meu leite e dá mas - tirar o leite dá tanto trabalho! Tanto trabalho que eu prefiro dar, estar aqui, presente nas mamadas dele e tal, e dar... é mais... assim, eu tenho que tomar... tô tentando tomar coragem. Eu vou sair e vou demorar mais. Vou deixar tudo preparado pra ele tomar o [marca do leite], mas eu não consigo!
\end{abstract}

Isabela faz um levantamento dos obstáculos que ainda estão por vir, no que parece uma tentativa de prever as dificuldades e talvez se preparar melhor para enfrentá-las. A antecipação é frequente em seus dizeres, e eu penso que é fruto da possibilidade de levar em conta aquilo que the importa tomando como base seus quereres. Assim, ela considera as rupturas necessárias para o desenvolvimento da relação com o filho, as separações que ocorrerão quando ele começar a comer alimentos sólidos e quando ela voltar ao trabalho. No entanto, ela não planeja deixar de trabalhar para evitar novas perdas:

\begin{abstract}
E também tem essa quebra aí, né? De estar o tempo todo junto com ele e, de repente, não estar mais. Mas em nenhum momento eu penso em não voltar a trabalhar. Não sei. Pode ser que eu tenha essa sensação um pouco mais pra frente, quando eu estiver perto de... não me vejo nesta vida o tempo inteiro, nesta vida em que eu tô. Não vejo a longo prazo isso... não consigo me ver. Tem mulher que não, né? Tem mulher que tem filho e fala "ah, eu trabalho por obrigação, se eu pudesse, eu ficava"... eu não consigo me ver nessa situação por muito tempo.
\end{abstract}

Reflete sobre as possíveis escolhas e suas implicações tanto em sua vida como na vida de seu filho em outro momento de transição - a retomada de sua vida profissional -, tentando encontrar uma alternativa que contemple melhor os dois lados implicados, o de seu filho e o seu próprio. Pensa com quem deixar o bebê e como será sua rotina depois dessa ruptura.

O filho foi-se tornando cada vez mais familiar, e ela, menos estrangeira como mãe. Parece que a instalação de uma rotina e de ritmos no cuidado com a criança pode favorecer essa passagem do estranhamento inicial, característico dos primeiros dias do bebê, para esse tempo do conhecimento mútuo e da atenuação do 
impacto das perdas para a mãe. Isabela se autoriza a cuidar dele, a saber o que pode ser melhor para ele e sente sua importância para o filho. Diz ter tido uma "surpresa positiva": imaginava que o filho exigiria muito mais dela. "Ele superou as expectativas" - considera-o um bebê bonzinho, fácil de lidar. Acha que teve muita sorte.

A rotina pode ser uma estratégia para ajudá-la a conhecer seu filho. Não parece ser a aplicação de um gesto mecânico, vindo de fora - de um livro ou de um pediatra -, mas fruto de sua conexão viva com a criança. A rotina também pode ajudar a instituir ritmos para o bebê - e para os pais - e é fundamental nos primeiros momentos da constituição de seu psiquismo. De certa forma, é um ordenador do caos inicial para todos os envolvidos. Pode ainda facilitar a instalação da presença-ausência materna, e, no caso de Isabela, parece propiciar muito prazer.

Tanto o "manhês" da comunicação entre mãe e filho com naturalidade e satisfação quanto a dinâmica do casal refletem o ritmo que se logrou estabelecer na família. O pai parece estar mais tranquilo, pois percebe que tudo corre bem; está mais esperançoso com sua vida profissional, e a atividade sexual vai voltando ao normal, com os acertos necessários para que haja maior harmonia entre eles. Isabela teve participação ativa na mudança da engrenagem familiar:

As coisas se ajeitaram, se ajeitaram. Já estamos numa rotina. Ele começou... Um mês atrás, a gente pensou em contratar uma babá de fim de semana, porque, nos fins de semana, ele falou que não conseguia descansar... teve um dia, teve uma época, teve um dia em que ele ficou irritado porque não conseguia ler o jornal. Eu falei "meu filho, mudou a sua rotina! Eu não consigo nem... eu deixei tudo, eu deixei meu trabalho, deixei de fazer tudo, você não pode deixar de ler seu jornal?"

Lembrando as perdas que sofreu em sua vida pessoal com a vinda do filho, ela faz com que o marido divida com ela esses prejuízos.

Eu falei "só eu que me ferro? Pra você, nada mudou?" E olha que, perto dos outros, eu sei que ele era um bom pai, porque ele participava, trocava, fazia... Mas fazer essas coisas quando não está fazendo nada, agora, abre mão das coisas que você faz sempre!

Penso que o desamparo que se sente com o total remanejamento e com as perdas que decorrem da vinda de um filho pode ser atenuado, mas não extinto da vivência materna. No caso de Isabela, o abrandamento se deveu a uma rede de 
apoio que se mostrou eficiente, e ela pôde contar com certos recursos psíquicos, sobretudo com a possibilidade de entrar em contato com suas perdas e de instalar ritmos na rotina do bebê, em sua própria e na do marido. Isso parece ter sido fundamental, pois permitiu que se contivessem o estranho representado pela figura do bebê e por ela mesma no papel de mãe. O ritmo dá um contorno ao que se apresenta, a princípio, disforme e sem garantias: a vida humana de um ser que precisa de investimentos para sempre.

Nosso encontro parece ter sido muito satisfatório para Isabela. Ela o aproveita, e eu também. Somos nutridas mutuamente por esses momentos. Por último, ela me pergunta se há possibilidade de, em algum outro momento, fazer terapia comigo. Penso que realmente se instalou entre nós alguma coisa a mais do que entre uma pesquisadora e uma participante da pesquisa.

\section{ÉRIKA}

\section{ENCONTRO GESTACIONAL}

\section{Sobre o susto}

Encontrei-me com Érika em sua 37ª̣ semana de gestação. Estava grávida de seu segundo filho e me foi indicada por uma pessoa conhecida. Tive alguma dificuldade para me encontrar com ela; só consegui a entrevista na terceira tentativa.

Inicialmente, quis fazer a entrevista em seu local de trabalho (num intervalo), e escolheu uma sala em que provavelmente haveria muitas pessoas. Algum tempo antes da data combinada, desmarcou em função de alguma questão de trabalho. $O$ mesmo aconteceu uma segunda vez, e acabamos marcando em sua casa, uma semana depois do encontro marcado na segunda vez. Assim, vislumbrei uma certa resistência ao contato efetivo.

No dia e horário marcados, me recebe cordialmente em sua casa. Havia uma pessoa limpando a sala do encontro, mas não me pareceu que Érika se importasse com o fato. 
Perguntei como havia sido sua gestação e como ela soube que estava grávida. Ela perguntou se eu me referia à segunda gravidez. A dúvida me pareceu interessante, e eu esperava compreender seu significado ao longo de suas falas. Disse-lhe que me referia à segunda, mas que, se ela quisesse, poderia falar também sobre a primeira.

\begin{abstract}
Ah, não, da primeira foi quando eu comecei... é, quando eu liberei, né? [risos]... eu fiquei grávida de prime... logo de princípio... logo de primeira. Eu percebi que meu peito tinha aumentado e que tinha atrasado a menstruação. Eu tava no trabalho e fui no banheiro. Comprei um teste na farmácia, aí vi que... nossa! tô grávida, tal. Eu tava no meio do trabalho.
\end{abstract}

Dessa, agora... também foi de primeira, a mesma coisa... e... eu percebi porque as roupas... bom... acho que eu tava meio gordinha, dessa vez. As roupas estavam mais justas, e aí foi logo. Eu comecei a perceber que... como eu já sabia dos sintomas, achei que tava grávida novamente e tava mesmo. Então, foi assim... foi planejado, não foi nenhuma loucura, porque foi bem pertinho [...] então, tá bem próximo. Foi tudo planejado, sem nenhum susto... [risos]

Apesar de ela dizer que as duas gestações foram planejadas, vai indicando certa ambiguidade, o que me fez pensar que as viveu com uma nuance de surpresa. Hesita ao dizer que tanto uma quanto a outra foram "logo de primeira", porque "de primeira" pode indicar um susto, algo que vem sem preparação, sentido que Érika vai reiterando em seu dizer. Pensei comigo que um filho planejado não é prerrogativa de uma gravidez consumada sem susto. Perguntada o que queria dizer com "de primeira", ela responde:

Não, que eu não precisei ficar esperando, não foi uma coisa assim... eu tentei e, quando eu liberei, consegui engravidar, né? Eu nem conto para minhas amigas, porque eu tenho um monte de amigas que estão com dificuldade para engravidar. Então, é até um absurdo cê ficar dizendo que foi tão fácil engravidar, né?

No princípio, tem um ar de quem executa, de certa eficiência. Ela fala de seu trabalho com grande eloquência, valoriza sua carreira, dedica seu tempo e investe no trabalho, e, quando nasce seu primeiro filho, parece que algo se rompe.

[...] Então, eu também queria ter filho logo, pelos problemas que, também, se esperar muito... eu acho seus riscos são maiores, né? E aí, como eu também fiz mestrado, fiz doutorado, eu preferi esperar [...] assim, eu esperei bastante para ter meu primeiro filho em seguida. Então, agora foi... passou o momento de trabalho, e agora é o momento eu, eu-família...

Sobre a divisão entre trabalho e família, ela continua: 
Não é porque eu acho que eu investi bastante na minha carreira, acho que, com filho, assim, eu vejo minhas amigas que fazem doutorado e têm filho pequeno, a loucura que é, assim elas não conseguem. Eu tenho uma amiga que está desesperada. Ela está com dois filhos, morando no interior, não encontra ajudantes. Assim, está superdifícil para ela continuar, para terminar. Fez os créditos e agora tá desesperada para continuar. Eu acho que eu tentei e arrisquei, poderia não conseguir, ou ter muita dificuldade para conseguir ter filho, mas na vida a gente tem que dar uma arriscada de vez em quando [risos].

Sobre as impressões, ideias e sensações que teve quando soube que estava grávida, Érika referiu-se novamente à primeira gestação, quando se tornou mãe. Penso também que as duas gestações parecem ter sido vividas como se fossem um bloco único: talvez isso indique uma dificuldade de diferenciar uma de outra ou se a primeira gravidez inaugura o constelação da maternidade, a instalação e construção do papel materno:

Ah, eu fiquei supercontente, fiquei bem feliz... todo mundo fala que é a melhor coisa do mundo, ter filho. Acho que, quando você não tem filho, você não sabe o que é realmente esse sentimento, esse carinho, esse amor, né? Acho que depois, na hora que você tem filho, você fala "nossa, como eu achava - é até clichê falar isso -, mas, nossa, como eu consegui pensar minha vida sem um filho", né? Então, isso que eu acho que foi assim, vou esperar... era uma coisa que eu queria. Foi muito legal mesmo... muito legal mesmo!

Quando Érika fala sobre a segunda gestação, percebo como uma tentativa de amenizar o impacto do novo que poderia sobrevir com o nascimento de mais um bebê, dizendo que já sabe tudo o que sobrevirá ao nascimento do filho. O "efeito surpresa" aparece transvestido de "saber", talvez numa tentativa de não ser pega pelo excesso, pela angústia que pode conter o não saber, o desconhecido.

Da segunda, eu também fiquei contente, mas eu já sei tudo que vem... nem é mais nenhum... eu não sou mais mãe de primeira viagem, eu já sei tudo o que vem por trás... e o tempo que eu tenho que me dedicar, o que isso tá mudando a minha vida, eu trabalho bastante, eu gosto muito de trabalhar, e eu tô tentando agora não invadir o fim de semana. Eu trabalho sábado e domingo sem nenhum problema: abria o computador, respondia e-mail, fazia as... E hoje eu tô vendo que não dá mais pra ser assim. Eu realmente tenho que fazer... dividir muito mais meu tempo, pra poder ter qualidade de tempo com meu filho.

Fala com grande admiração numa amiga que já têm três filhos e em como ela administra seu tempo e investimento nas tarefas maternas e profissionais: 
E aí, quando eu não tinha filho, ela era minha amiga do relógio: "duas horas, eu preciso sair, porque eu preciso amamentar; três horas, eu vou levar meu filho na escola, quatro horas..." [risos] Então, eu falava "nossa, como você se organiza". Mas tem que ser tudo no relógio, se não, você não consegue fazer as coisas. Tem que ser assim...

Érika parece simbolizar na "amiga do relógio" um ideal de organização rígido para dar conta das inúmeras demandas, para não sair do esperado e do programado e talvez como forma de tamponar a angústia que pode emergir nesse período na vida da mulher.

Hoje, as prioridades são outras. Então, eu fico... às vezes, um pouco com ele, depois eu vou trabalhar, depois que ele dorme, mas aí eu morro, eu tô grávida, tá meio maluco. Essa gravidez foi assim, um pouco mais difícil, porque eu tive nessa confusão. Eu tive reforma na minha casa, fui morar na casa da minha sogra, foi super, né? Foi superagradável, tal, mas você não está na sua casa, é diferente. Mas, ao mesmo tempo, minha mãe ficou... ia operar a tireoide, era câncer, não era câncer... E, ao mesmo tempo também, eu tive... eu precisei ficar de repouso. Então, eu fiquei de repouso na primeira gestação, eu tinha coisa... o cordão umbilical não era no centro, era na ponta, isso era super-raro, as mulheres terem essa inserção do cordão umbilical. Eu fiquei de repouso, no final. Nessa, eu fiquei de repouso desde setembro. Eu engravidei em julho. Desde setembro, eu fiquei trabalhando em casa, porque eu precisava ficar de repouso porque eu estava com placenta prévia. Eu precisei ficar de repouso. Então, como eu gosto de trabalhar, eu falei "vocês vão me enlouquecer se eu precisar ficar deitada aqui sem fazer nada”...

Sua fala vai produzindo em mim um forte impacto quando ela conta que passou grande parte da gestação em repouso, que sangrou muito, chegando um certo dia a desconfiar que havia perdido o bebê. Senti também uma espécie de susto, como o efeito de uma surpresa. Acredito que me tenha contagiado com o clima de "eficiência" que Érika algumas vezes emana. Só depois de algum tempo se descobriu a placenta prévia, o que a levou a ficar em repouso grande parte da gravidez, impedindo-a de cumprir tarefas de rotina como, por exemplo, dirigir e trabalhar normalmente, o que ela parece sentir como perdas importantes.

Conta-nos também que, quando seu filho nasceu, houve um erro médico na maternidade sobre a tipagem sanguínea e o fator $\mathrm{Rh}$ do bebê. A enfermeira dissera que seu sangue era $A B$ positivo, e, como ela e o marido têm $R h$ negativo (o que inviabiliza terem um filho $A B$ positivo), cogitou-se a possibilidade de uma troca de bebês. 
A fala é carregada de conteúdos ameaçadores, mas ela não parece entrar em contato com eles. Eu me assusto, acolhendo o impacto de suas emoções não digeridas. Parece ter sofrido o impacto, mas procura atenuá-lo.

Apesar do contato um pouco limitado com seus conteúdos mais frágeis, há uma mudança sutil na posição de Érika ao longo da entrevista. Ela continua a me contar outras experiências difíceis que se seguiram ao nascimento de seu primeiro filho, bem como sua preocupação com a percepção de que seus pais estão envelhecendo, fato que Ihe gera sofrimento. Emociona-se ao falar dos pais: "Meu pai e minha mãe são as coisas mais bonitas da minha vida". Logo depois, parece tomar algum contato com as próprias fragilidades:

Na primeira gestação, eu achava que era bobagem mulher que enjoava, então, até hoje, eu sinto um cheiro forte, um perfume forte, um desodorante forte, material de limpeza mais forte, isso me enjoa, não dá assim, o cheiro fica forte, mas tudo bem. Eu achava que era uma bobagem mulher que enjoava na primeira gestação, e na segunda eu paguei minha língua, porque eu fiquei, eu tô enjoada. Até hoje, tem algumas coisas que eu olho e não consigo comer, mas faz parte. Daqui a pouco, eu volto ao normal.

Senti certa dificuldade de acompanhá-la na primeira entrevista. Érika fala muito depressa, coloca muitas questões, e me parece que elas escorrem por sua fala sem que ela consiga se apropriar delas. De certa forma, Érika exprime uma grande turbulência interna, mas suponho que ela tenha dificuldade para entrar em contato com suas áreas mais sensíveis, as quais têm um impacto considerável em mim.

Percebo em sua dinâmica emocional certa cisão entre a potência - aquela que executa mas tem dificuldade de se retirar para se preocupar primariamente nesse momento de ter um filho - e os aspectos mais sensíveis, mais difíceis.

Do que ela diz, depreendo que o planejamento de uma gestação não garante efetivamente que não haja sustos, surpresas ou que não cause certa desorganização tanto na mulher quanto no ambiente familiar. Apesar de seus esforços, o desarranjo se impõe na reforma da casa, pensada tardiamente e que rende um grande transtorno, na doença de sua mãe, que a preocupa muito, na necessidade de procurar outra babá, pois a antiga também está grávida e se afastará, bem como no repouso que precisou fazer em virtude do risco na gestação. 
Sem dúvida, estas são situações desorganizadoras e que expõem aqueles que as vivem a estresse emocional, especialmente quando estão em vias de acolher um novo bebê, mas me chamam atenção em Érika sua dificuldade de reconhecer em si mesma a fragilidade (exceto quando fala dos pais) e sua tentativa de se apresentar como forte e capaz de enfrentar as dificuldades, às vezes tentando negar as situações de grande impacto emocional que viveu ou que poderá vir a viver nessa sua nova empreitada.

\section{PRIMEIRO ENCONTRO APÓS O PARTO}

\section{Sobre o impacto do nascimento}

Essa entrevista aconteceu uma semana após o nascimento do bebê, no quarto do casal, na cama, com o bebê dormindo. A casa de Érika ainda estava em reforma, num grande tumulto e com muito barulho. Senti certo impacto por presenciar uma reforma desse porte na presença de um bebê que acaba de nascer.

Quando Ihe perguntei como tinha sido o parto, ela respondeu com o motivo pelo qual o filho nasceu uma semana antes da data prevista. Sobre os porquês, conta que foi o fato de ela ter engordado muito no fim da gestação e o de o bebê já pesar bem mais do que pesava o mais velho quando nasceu. Aqui, penso que começa a se romper a ideia de que a mãe já sabia como seria o segundo filho.

Penso também que o parto representa um momento significativo e que, talvez por ser tão impactante, dificulte a possibilidade de Érika representá-lo. Mas ela assume o terror que Ihe causou a anestesia, indicando a face traumática desse evento.

[...] eu só não gosto da anestesia; da anestesia, eu não gosto; eu tenho horror da anestesia. Nas duas - eu não gosto de não sentir as pernas; eu tenho uma impressão horrorosa de não sentir as pernas. Eles colocarem minhas pernas assim, pra cima.......] acho péssimo. Eu reclamei para o anestesista da primeira vez, reclamei da segunda. Foi onde eu fiquei nervosa: foi na anestesia. Mas por não sentir a perna - não é pela anestesia não. É por não sentir a perna. Quando essa tralha, quero sentir minha perna de volta. Ele nasceu meio-dia, meio-dia e pouco. Fui sentir a perna às cinco da tarde. Falei "ai, que raiva". Mas nasceu, tudo bem... 
Sobre o bebê, diz que nasceu bem e que foi tudo bem. Podemos pensar que a angústia disparada pelo parto é tão intensa que dificulta qualquer outro investimento nesse momento.

Érika se preocupa também com o filho mais velho, e espera que, mesmo com o nascimento do bebê, ele tenha vida normal e faça normalmente as coisas do dia a dia: "não é nada, não é nenhum espetáculo...". Parece querer protegê-lo de alguma forma ao tentar anular o impacto da presença de um irmão em sua vida, e isso pode representar mais um óbice em sua ligação com o novo bebê.

Assim, vemos que, ao nascer, esse bebê deve dividir a atenção de sua mãe com uma reforma, um irmão, os avós... Penso em como esses elementos poderiam intervir na relação de Érika com ele.

Por determinação da pediatra, Érika se vê obrigada a anotar o horário das mamadas. Ela não sabe o motivo desse pedido, mas depois diz que amamenta de hora em hora. Pergunto por que, e ela diz não saber muito bem, mas acaba dizendo que faz isso porque gosta de amamentar. Ela acredita que a pediatra Ihe tenha pedido para anotar as mamadas porque o bebê está sendo amamentando numa frequência muito alta.

Sobre o primeiro filho, diz que a babá que cuidava dele tinha vindo de uma família com horários muito rígidos, e Érika acha que isso ajudou muito nos cuidados do seu filho, que sempre dormiu sozinho. Ao mesmo tempo, diz que, quando o bebê chora, ela acolhe, pois a pediatra alertou-a de que os três primeiros meses são fundamentais para o desenvolvimento psicológico.

Sua fala sempre parece indicar que as recomendações da pediatra são seguidas à risca, e não parece haver espaço para questionamentos ou para uma tentativa própria de entender o que está acontecendo e, assim, tornar seu filho familiar, conhecendo a nuance de suas manifestações e comportamentos a partir do contato íntimo com ele. Érika parece acreditar que os cuidados são uma questão técnica e que é a pediatra que conhece essa técnica. A ela própria, Ihe cumpre seguir suas orientações, pois a pediatra "estudou para isso". Podemos pensar que, assoberbada pelas demandas geradas pela chegada do novo bebê, Érika não 
encontra recursos para se voltar para ele e se protege ancorada nas recomendações médicas.

O impacto e o desequilíbrio causados pela entrada de mais um membro na família só pode aparecer com o ciúme do filho mais velho. Érika não compreende como ele não manifesta esse sentimento diretamente no bebê, mas ele tem apresentado comportamentos agressivos contra o pai, a mãe e a babá. Érika se entristece com isso; parece sentir-se traída e bastante ressentida: "[...] Você faz tudo, tal [...] Eu juro por Deus... Cê fica até triste, cê faz tudo, tal [...] eu tô ficando meio maluca...". Ao mesmo tempo, tem dificuldade de reconhecer uma forma própria de seu filho mais velho se expressar.

Nesse contexto, ela se esforça para atenuar o impacto que isso parece ter sobre ela: "Mas tá indo. Tô superfeliz, tô supercontente. Ser mãe em período integral, né? O mais legal de tudo é ser mãe em período integral, coisa que eu não sou [risos]". Esse parece ser o grande susto de Érika, após o nascimento do segundo filho - o impacto maior!

Ela parece intrigada com o fato de o filho mais novo ser muito diferente do mais velho. Nasceu maior e mais gordinho. Fisicamente, é muito diferente do irmão.

Logo depois dessa fala, Érika diz que ele é muito fofinho e emenda dizendo que seu peito foi machucado e que a pediatra a orientou a colocar o bebê sentado para mamar, para evitar ferir mais o seio.

Fala também da diferença de tratamento quando se é mãe pela primeira vez e pela segunda. Desta vez, não recebeu muitas informações na maternidade, e as pessoas a visitaram menos do que quando nasceu seu primeiro filho. Fala das visitas como se elas preenchessem ou amenizassem alguma coisa, uma certa angústia: "Senão, fica aquela chatice [...] então, eu acho que o tempo passa mais rápido. Eu senti bastante dor nessa segunda cesárea. Bastante dor...”.

Suponho que ela tenha alguma dificuldade de fazer contato com o filho que acaba de nascer. Parece evitar o mergulho na experiência por alguma razão, talvez justamente pelo impacto do surgimento do bebê real, que saiu de seu ventre... $\mathrm{Na}$ 
maior parte das vezes, cita a mudança de comportamento do filho mais velho, mas não fala muito sobre o mais novo.

Érika diz que nunca teve problemas com o leite, a menos de certo ingurgitamento, que não se lembra de ter tido na primeira vez.

Percebe que determinadas decisões afetam sua vida, como a reforma que foi decidida quando ela estava no final da gestação e que avança após o nascimento do bebê. Preocupa-se porque precisa falar com os marceneiros que agora trabalham em sua casa e não tem roupa adequada. Parece muito difícil desinvestir de outras questões para poder investir no filho que chega. Aparentemente, ela têm dificuldade de permanecer no estado de preocupação materna primária.

Érika se incomoda muito por estar limitada, sem poder dirigir; tem que resolver tudo perto de casa e pede à chefe que a copie nos emails, para não ficar sem saber o que está acontecendo no trabalho.

O marido e a mãe assistiram ao parto do primeiro filho, mas só a mãe assistiu ao segundo: o marido disse que não entende nada, não sabe se está bom ou ruim, e é muito sangue. Ele ficou em casa com o filho mais velho, mas "a mão da minha mãe foi fundamental pra eu segurar naquela hora. Foi fundamental".

Está preocupada por ter ganho muito peso na gestação, o que pode reverberar em sua saúde no futuro e incrementa sua angústia. Assim, esse bebê parece ter nascido em meio a questões pessoais de Érika, e ela tem dificuldade de fazer a regressão necessária à preocupação materna primária.

O bebê parece não demandar muito da mãe; ela o descreve como bonzinho: mama direito, dorme bem e tomou banho sem chorar.

Com o segundo filho, o marido tem ajudado. Ele a está surpreendendo; "parece até outra pessoa". Coopera principalmente nos cuidados com o primeiro filho, talvez porque ele é maior; normalmente, põe o menor para arrotar.

O bebê chora, depois para. Chora de novo, e Érika pergunta se ele quer mamar. Depois, pergunta se o filho está na dúvida. 
Ao longo da entrevista, os telefones tocam e ela atende. Toca primeiro o telefone de casa; enquanto ela falava com o marido, toca o celular - era a irmã. Nesses momentos, nossa conversa se interrompe.

Érika toma as falas da pediatra como leis a serem respeitadas e seguidas. Não as questiona, talvez para não entrar em contato com o que as experiências the vão causando.

Segundo a pediatra, uma criança pode chorar por cinco motivos: fralda suja, fome, gazes, aconchego e o choro da reorganização. Érika diz que até hoje não sabe de que se trata, este último choro.

Ela fala um pouco do incômodo de estar numa casa bagunçada, em reforma. Parece dizer da reorganização necessária que sobrevém à chegada de mais um integrante na família. Tudo se desorganiza, tudo sai do lugar e ainda não encontrou um novo lugar: "O outro só quer tomar o leite comigo. Ele gosta de tomar ali, que era a antiga varanda, olhando pra rua. Não tem varanda porque a sala tá uma zona. Aí, ele tem que tomar aqui..."

Sobre a tristeza, Érika diz que "isso não bate lá". Mas fala na percepção e na preocupação de que seus pais estão ficando mais velhos e concorda que isso pode ser tristeza. Ainda sobre a tristeza, volta a mencionar a mudança do comportamento do filho mais velho depois do nascimento do mais novo e o fato de a responsabilidade ter aumentado com o nascimento deste. Se mostra preocupada com o filho mais velho e procura encontrar espaços preservados para ele.

Em Érika, a tristeza aparece camuflada no ciúme do filho e na preocupação e no cuidado com os pais, mas ela está presente e a desestabiliza parcialmente, apesar de suas tentativas de atenuar o impacto dessa mudança radical em sua vida. A bagunça da casa em reforma parece ser sintomática e emblemática: há o barulho da furadeira trabalhando na obra, há lugares que não existem mais, outros que estão sendo criados... A impossibilidade de se deprimir parece sobrecarregar Érika: parece que ela não se pode ocupar primariamente com o bebê, pois está sobrecarregada com outras preocupações. 


\section{SEGUNDO ENCONTRO APÓS O PARTO}

\section{Entre o "caos" e o "está tudo bem"...}

Entrevista realizada dois meses após a primeira, no puerpério.

As perdas e os impactos reverberam na dinâmica da família como um todo, e parece ser o filho mais velho que denuncia certa desorganização ocorrida no seio familiar, com a chegada de um novo membro. O menino está mais sensível e parece mostrar que, apesar de todos os esforços da mãe para amortecer os impactos sentidos, experiências como o nascimento de um irmão - ou de um filho, no caso dos pais - têm repercussões importantes.

Outro dado significativo parece ser simbolizado pela necessidade de internação do bebê numa unidade de terapia semi-intensiva durante seis dias, devido a uma séria inflamação nos brônquios. Érika parece ter vivido essa experiência de forma traumática. Indicada abruptamente, foi significada como um "caos", mas ela logo tenta amenizá-lo, dizendo que agora estava tudo bem:

De terça a domingo, foi um caos, numa semi-intensiva. Aí, na terça-feira, a pediatra passou aqui em casa - ela tava saindo do hospital e passou aqui. Ela disse: "Não, Érika, vamos internar agora". Foi coisa de cinco minutos. Catei minhas coisas, botei numa mala, a gente foi. Tá tudo bem agora, tá tudo bem... mas, agora, tá com refluxo nasal. Acabei de vir da pediatra hoje, mas haja coração...

E ela continua falando sobre o susto que sentiu com a situação inesperada:

Foi um supersusto, viu? Eu nunca tinha ficado numa semi-intensiva - achei que era coisa de novela, sabe assim? [risos]... Aquele alarme tocando toda hora: mé, mé, mé... As enfermeiras... É super sensível. Eu falei "isso aqui é coisa de maluco". Olha, tem uma câmera focalizando a cama, tem uma câmera não sei quê, mas, no final, deu tudo certo... Mas eu nunca tinha ficado numa semi-intensiva. Depois foi legal. A médica passou a gente pro outro lado do corredor, que era um quarto normal, pra quando a gente chegasse em casa ficasse com segurança, não achasse que ele não tava bem, tal. Aí, foi isso: a gente voltou, aí a vida continua.

O susto causado por uma internação tão abrupta numa idade tão precoce parece não poder ser muito falado, muito tocado. Não tenho intimidade com Érika, não sou sua analista, mas penso que talvez o fato de ela não falar muito sobre um tema tão delicado e que a impactou muito seja uma forma de reação. Ela se apressa 
a dizer que deu tudo certo, mas que, naquele momento, outra questão a preocupava - o ciúme do filho mais velho: "mas deu tudo certo: agora, eu tô administrando um pouco o ciúme, né?".

É interessante pensar como Érika pede minha participação. Às vezes, parece usar a entrevista para me fazer perguntas diretas sobre algumas questões: por exemplo, a angústia de saber que o filho está apresentando um comportamento mais "sensível" na escola:

[...] mas disse que na escola, então, amanhã, eu vou falar com a professora. Disse que na escola... a professora não me chamou, nada, eu que vou lá. Meu marido é que perguntou... tá mais sensível, a gente percebeu desde que o bebezinho nasceu - tá mais sensível...

Quando perguntei como aparecia a sensibilidade, Érika responde que não entendeu a que a professora se referia:

Ah, isso eu também não sei. Boa pergunta. Vou descobrir com a professora agora. Não sei se tá chorando, não sei como é que tá. Diz que tá mais sensível e que tá brincando mais sozinho na escola. Então, não sei, também. Achei que fosse conseguir ir hoje na escola, mas foi um inferno - mas tudo bem. Então, amanhã, minha tarefa é ir na escola conversar com a professora para saber o que... Se eu preciso fazer alguma coisa ou se isso é normal. Se isso é normal - é normal? Você que lida com essa turma aí [...] Eu não sei... Criança ficar sozinha... Eu não... Criança brinca junto, brinca separado... Brinca separado ou brinca sozinha? Eu não sei...

Outro tema recorrente nos encontros com Érika é o fato de ela acabar sendo alguém que "cumpre ordens", como no caso das orientações da pediatra. Ela se sente frágil e não autorizada, num mundo dominado por orientações técnicas, mas isso faz com que ela não consiga lidar com suas fragilidades e nem aprender a entender seu bebê. Podemos compreender como é difícil desvencilhar-se disso, mas, por outro lado, sabemos como seria importante se pudesse aprender a ouvir o que the pode dizer seu bebê.

O que manda fazer, eu faço [risos]. Se manda subir na árvore, eu subo; se manda descer da árvore, eu desço! [Risos] Eu cumpro. Você me fala, eu cumpro. Eu cumpro tudo o que me fala. Tem que dar de pé, eu dou; não pode balançar o bebê, eu não balanço o bebê; a gente vai fazendo o que manda a gente fazer. Porque aqui, à noite, era o caos... Das seis da tarde até as dez da noite, choro, choro e choro; chora pra cá, e chora pra lá. Aí, ela já me explicou: é o choro da reorganização. Aprendi que é o choro da reorganização, sempre no mesmo horário [...] Esse choro, não entendi direito com [nome do filho mais velho]. Agora, eu entendi mais ou menos. É o choro 
[com] que ele está processando as coisas, tal. Então, ele fica mais... como é? Ela usou uma palavra hoje - desconfortável - e chora. Se ele já estiver falando "ah, ah, ah" ou sorrindo, ele já está entendo melhor o ambiente - o choro da reorganização! Então, vou te falar, viu?

Com a dificuldade de entrar numa conexão mais afinada com o filho para entender o que pode estar acontecendo, parece imperar apenas a vivência de um "caos". A dificuldade de entrar em contato com o que não está bem, com as coisas desorganizadas, acarreta uma dificuldade de pensá-las e processá-las, mas fundamentalmente parece haver certa dificuldade para o investimento no bebê, supostamente devido à dificuldade inicial de regressão característica do estado de preocupação materna primária, bem como talvez a dificuldade de se deprimir saudavelmente após o parto, típica do baby blues.

Um exemplo disso parece ser a amamentação. Apesar de o bebê estar em amamentação exclusiva, pode haver certo prejuízo de prazer nessa atividade.

Amamentar, eu gosto. Eu gosto, mas eu gostava mais quando era o outrosó tinha isso pra fazer... Agora, com esse... Mas é muito engraçado, né? Porque, com o outro, eu até dormia amamentando. Com esse, não dá pra dormir. Não teve nem um dia que eu dormi até agora, porque eu tenho... Eu tenho que dar leite pra ele, eu dou o leite do outro [...].

Mas é engraçado: primeiro, eu dormia; com esse, não dá... Coitado. Acho até que é uma amamentação fast food: põe no peito, tira do peito, põe pra arrotar - é punk, né? Mas isso é a maior diferença que eu acho, no segundo filho. No primeiro, eu curti, foi o máximo, tal. Não sei que, isso porque eu nem era nhé, nhé, nhé, não. Eu achei legal. Então, foi superlegal, e... amamentar, tal... Esse segundo, tem que administrar o outro [...] Acho que, daqui a pouco, tudo vai melhorar, mas [...]

Outro momento que parece ser emblemático de uma dificuldade de investimento no bebê é o da brincadeira com o filho

E bebezinho, não tem muito o que fazer. Cê põe na cadeirinha, cê põe no tapetinho. Ainda não é pra sair na rua, né, filho?

[...] Sair na rua, na rua... sei lá... eu falo "gente! Acorda, dorme, fica chorando, mas não quer dormir, mas não quer mamar, não quer a cadeirinha, não quer nada, né?

No horizonte materno, a vinda de um segundo filho pode ter um impacto diverso da do primeiro, pois geralmente amplia o peso das obrigações, e pode haver um acúmulo de funções e pressões de fazer mais um filho viver, ao mesmo tempo em que é preciso continuar a investir no filho mais velho. E há, como no caso de 
Érika, uma necessidade de administrar os impactos decorrentes da vinda desse novo membro tanto em seu psiquismo quanto no seio familiar. Percebemos que ela está sobrecarregada de preocupações e afazeres, o que Ihe dificulta certa entrega à tarefa de ser mãe do bebê que chega.

Percebo também que há uma espécie de obrigação de "estar bem", de "ter bom humor", apesar de todo o "caos" sentido, impondo uma exigência excessiva de amortecer os impactos, seja da tristeza, seja do caos, seja das perdas... Nesse sentido, há também um reforço cultural: nossa sociedade parece impor um certo júbilo, principalmente à mulher que acaba de ganhar um bebê.

A perda de liberdade sentida com a vinda do filho the parece opressiva: "Eu não saio da minha masmorra! Eu não saio! Eu vou pro médico, volto. O máximo que eu faço: eu vou até a esquina e volto [risos].

Parece sentir-se numa prisão: o engajamento necessário à dedicação a um recém-nascido é sentido como excessivo e aprisionante.

A relação com o bebê fica comprometida por todas as exigências que the diluem os investimentos entre tantos afazeres e tantas pressões... O bebê precisou ficar quase uma semana internado, o que reverberou negativamente.

Penso que ela não logrou acolher essas dificuldades, de modo que seu sofrimento não a levou a elaborar algumas perdas sentidas e pode chegar a impedir que o prazer faça parte de sua relação com o filho mais novo.

\section{TERCEIRO ENCONTRO APÓS O PARTO}

\section{É possível demandar?}

Essa entrevista foi feita com três meses de atraso, e eu tive que insistir para que nos encontrássemos. Cheguei a pensar que tinha perdido a participação de Érika no estudo e me perguntava pelo motivo de sua dificuldade em me receber. 
Érika continua amamentando o filho, e seu investimento nessa relação ainda parece difícil, agravado por preocupação com outras situações que lhe atraem a atenção e o investimento privilegiado no bebê nesses primeiros tempos.

Ela parece sobrecarregada com uma série de questões para as quais não encontra saída. Voltou a trabalhar, o que lhe dá prazer, mas sente que é mais exigida, pois o fato de ter agora dois filhos lhe impõe conciliar tudo o que já existia antes com a preocupação com a saúde do bebê, que teve novas intercorrências pulmonares, passou por várias sessões de fisioterapia e tomou medicamentos. $\mathrm{O}$ mais velho, por sua vez, precisou fazer duas cirurgias simples - que também ocuparam Érika -, e sua mãe também sofreu uma cirurgia. Suponho que todas essas questões a angustiam muito e pressionam a dinâmica da relação que ela estabelece com o filho que chega. E ela vai dizendo do excesso a que se sente sujeita:

Eu tô muito cansada, muito cansada, eu tô exausta!! Eu não aguento! Eu não aguento mais ir em pediatra, eu não aguento mais ir em médico nenhum. $E$ agora, sexta-feira, eu que vou fazer um check up! [risos] Eu falei "não, eu vou fazer", né? Mas, a gente tá... A GENTE NÃO AGUENTA MAIS... E assim, nisso tudo, eu tô com muito leite, graças a Deus! Não afetou em nada... E voltar a trabalhar, uma supercorreria, né?

Diz o bebê é muito bonzinho, mas que ficou muito doente, o que a deixa "exausta". Parece dizer que a dependência e o risco ainda rondam seu universo materno e que um excesso de pressão a fazem querer trégua, "férias com chuva": "É muito fofinho assim... Mas não vejo a hora de [ele] crescer!”

Érika parece muito dividida e angustiada nos cuidados com o filho, ficando entre o excesso e a falta:

Não, não... Mas tá indo, tô indo bem! Mas só queria que chovesse. [O bebê tosse.] Essa tosse, tá vendo? Tá muito seco! É engraçado porque inalação demais, diz que dá água no pulmão, e o vaporizador, minha pediatra não gosta muito! É engraçado... ou seja... toalha torcida e uma bacia. Outro dia, eu falei pra ela "Ah, eu liguei o vaporizador". Ela falou "Só por duas horas, e pode desligar, senão, fica úmido demais".

Ela procura lidar com a angústia causada por um turbilhão de coisas organizando suas atividades, mas o ritmo não volta ao padrão antigo, e ela não encontra um novo: 
Eu acordo e falo assim... Porque antes eu acordava falando "hoje, acho que eu vou fazer a unha, vou fazer..." Agora, eu acordo com toda a semana marcada. Então, hoje vem a Cristina, amanhã eu faço a unha lá lá lá... Senão, cê não faz nada! Se você não marca, não faz nada... É, senão, a semana acaba, e você não faz nada...

Percebe uma diferença entre os filhos. Sempre que ela oferece, o mais novo quer mamar.

Sobre o marido, diz que ele ajuda bastante com o filho mais velho.

Parece que às vezes se fazem escolhas sem pensar nas implicações. Sobre a reforma da casa, depois dos transtornos que ela causou, diz: "Quando olho pra trás, eu digo "gente, que louca que eu fui".

Pelo modo como ela fala, penso que o bebê ainda é um estranho para Érika, que não consegue aprender sobre ele, torná-lo mais familiar. Os outros é que sabem.

Ela mostra ter sido sobrecarregada por situações potencialmente depressivas e desorganizadoras (doença da mãe, dos filhos...), mas parece ter uma personalidade que se sustentava num padrão de força e potência. Somadas, realidade e personalidade fizeram com que a única forma que ela pôde encontrar para sobreviver a essa situação tenha sido negar a depressão, apoiar-se no discurso médico, na rotina e em outros elementos para dar conta das angústias a que se viu submetida. No entanto, devo destacar que isso a impediu de ter um contato maior com essa nova criança, que se viu privada do que Winnicott chamou de preocupação materna primária e que tem um papel importante no desenvolvimento psíquico do bebê.

Com seu sofrimento, Érika me mostrou o excesso que pode representar a vinda de mais um filho na vida de uma mulher, sobrecarregando ainda mais seu psiquismo nesse momento particular. 


\section{GABRIELA}

\section{ENCONTRO GESTACIONAL}

Mudanças importantes pela frente...

Algumas questões se destacam na primeira entrevista com Gabriela. Apesar de ela dizer que sua gestação foi planejada, sugerindo que tinha sido sem sustos, não foi o que percebi, pois sua fala indica que ela engravidou antes do que esperava.

Por suas palavras, foi muito mais fácil engravidar do que ela imaginara, o que a surpreendeu, e ela parecia recear não seguir com a gestação. Penso que essa hesitação pode se dever ao fato de ela ter tido um câncer algum tempo antes, quando passou por uma cirurgia para a retirada do nódulo.

Gabriela diz que a gravidez foi "superbem aceita", e eu pensei por quem ela teria sido bem aceita e por que ela começa a entrevista me contando dessa aceitação, levando-me a crer que talvez tivesse medo de não conseguir engravidar e manter o bebê.

A fala de Gabriela indica o caminho das perdas em sua vida, desde antes da gravidez. Parece dizer que teve que abrir mão de sua liberdade pessoal no momento em que começou a namorar o marido, culminando numa mudança de país. As relações dão trabalho, implicam investimento afetivo e algumas perdas: "eu sempre fiz tudo o que quis".

Suponho que "eu sempre fiz tudo o que quis" e "se puxar a mãe e o pai, tamos fritos!" dizem do medo de agora sofrer os efeitos disso do outro, talvez ficar sujeita à vontade de seu filho. Parece também indicar a mudança de geração no horizonte dos pais engendrada pelo nascimento de um filho.

Essa mudança implica uma torção necessária, certo giro na perspectiva de "eu não dava satisfações pra ninguém" para "meu medo é mais a responsabilidade de criar uma criança...". Sabemos que esse giro não só é necessário como fundamental, mas envolve um importante trabalho psíquico dos pais e lhes exige um 
posicionamento subjetivo diferente. $\mathrm{O}$ investimento deve mudar de mãos, e sua liberdade pessoal parece ameaçada.

O casal quis aproveitar o fato de voltar ao Brasil para ter filho aqui, com a ideia que poderia também contar com mais apoio: a família estaria aqui, e eles conseguiriam uma funcionária para ajudar nas tarefas da casa. Falas como "Aproveitar para engravidar", "meu marido começou a falar em criança" e "a gente era o casal que ainda estava solteiro, vai, sem ninguém..." significam que todos os amigos do marido já tinham filhos. Essas parecem ter sido algumas das motivações mais conscientes para engravidar.

Outra transformação ou perda que parece ter tido um grande impacto em Gabriela - e, penso, representativa de seu movimento psíquico - é o fato de ter ficado muito chateada com seu estado geral no início da gestação: muito sono, digestão lenta, algumas náuseas e muito choro nos três primeiros meses; uma sensibilidade muito exacerbada: "Eu não aguento isso...". Ela fala em certa "impaciência" para ficar em casa, pois, quando era solteira, morava sozinha e não parava em casa, fazia todas as refeições fora de casa. Todas as noites, saía para jantar com alguém e só voltava para casa para dormir. Suponho que Gabriela valoriza muito o contato social, e imagino que isso talvez, indique alguma dificuldade de se deprimir saudavelmente em certos momentos ou de se recolher em determinadas circunstâncias.

Assim, associados ao desejo de engravidar, vão aparecendo os lutos decorrentes, que não estavam previstos no projeto idealizado. Como poderá Gabriela lidar com esses aspectos ao longo de sua relação com seu bebê?

Ela conta das diferenças culturais entre ela e o marido; parece dizer que vive entre dois mundos e diz que o filho terá um nome que se possa pronunciar em várias línguas - um bebê do mundo -, uma vez que pode mudar mais algumas vezes de país. Essa mesma perspectiva aparece quando ela fala da possibilidade sempre presente - de o marido mudar de trabalho. Ela transmite uma certa ambiguidade: por um lado, se ressente da falta de raízes no estrangeiro; por outro, teme criar raízes, não consegue ficar parada em casa - é um pouco estrangeira em seu país. 
O contato comigo é um pouco tenso, no início; parece que ela acredita que existe um jeito certo de fazer as coisas, o que foi gradativamente diminuindo ao longo do encontro, talvez por ela ter percebido que eu não estava ali para julgá-la.

\section{PRIMEIRO ENCONTRO APÓS O PARTO}

\section{Mamãe correndo a maratona...}

Esse encontro só pôde acontecer 26 dias após o parto. Gabriela conta que as primeiras semanas foram tranquilas: o bebê acordava para mamar de quatro em quatro horas na primeira semana, passou a acordar de três em três na segunda, e, depois disso, "bagunçou". O bebê chora intensamente das seis horas da manhã até perto das quatro da tarde. Ela diz que é "desesperador": parece sentir o impacto da presença do filho em sua vida.

O bebê nasceu 15 dias antes do esperado, e, tal como a notícia da gestação, isso causou um susto. $O$ exame que sua médica fez na consulta anterior ao parto indicava que o bebê nasceria em breve. Gabriela me conta: "fez o exame e falou 'tá pra romper. Você quer ir no susto ou vamos agora?' Eu o quê? O quê? 'Quer ir no susto?' Eu comecei a tremer, comecei a chorar, eu falei 'vocês estão de brincadeira, né? Tão de brincadeira que é agora, né’”.

Parece que a chegada do filho foi um abalo: não estava tudo arrumado! Assusta-se ao ver que chegou a hora, pois não estava preparada; foi pega desprevenida: "Eu falei 'tranquila? Tranquila? Como vocês querem que eu fique tranquila? Vocês me falam isso. Eu sei que eu tô aqui pra ter filho, mas assim?'”.

Apesar de dizer que as coisas concretas como mala, roupas e quarto estavam prontas, parece referir-se a uma espécie de falta de preparo, a não se sentir capaz, preparada para a chegada do filho. $O$ enfrentamento real com o bebê que o parto enseja parece indicar certa falta de preparação para esse encontro, simbolizando um verdadeiro excesso - apesar de Gabriela contar que foi também um momento emocionante. 
Ela sentiu muita dor com a involução do útero e pediu que sua médica a deixasse ficar um dia a mais no hospital, para sentir-se melhor. Penso que essa dor intensa fê-la adiar o confronto a sós com o filho, sem o amparo da equipe hospitalar.

Em Houaiss (2012), além de designar o retorno de um órgão dilatado a suas dimensões normais, como é especificamente o caso do útero no período puerperal, a palavra involução pode também significar um movimento regressivo, bem como a condição, ou o estado de um órgão que está voltado para dentro, e também um movimento transformacional idêntico a seu inverso. Os significados são intrigantes se pensarmos nas mudanças físicas, mas também nas psíquicas que ocorrem no período gravídico e depois no puerperal, quando o necessário movimento de regressão iniciado na gestação e continuado no pós-parto é salutar para fundar as bases da relação mãe-bebê, concorrendo para a instalação da preocupação materna primária.

É necessária não só uma involução do útero, que volta a um estado próximo ao anterior à gestação, mas não o mesmo. A gestação opera uma mudança significativa: nem o útero fica do mesmo jeito, e é preciso "voltar-se para dentro", regredir, para poder investir no filho que chega. Gabriela parece se ressentir dessa chegada e da necessária regressão psíquica. As regressões podem trazer muita dor, porque reatualizam conflitos e lutos não suficientemente elaborados que vêm à tona nesse período.

Sair, que era muito valorizado por ela ("eu sou muito de rua"), parece agora fazê-la sentir-se impedida, suponho que reverberando numa espécie de descompasso entre ela e o bebê. Ela não sabe a razão do choro intenso do filho. Disse que, nos primeiros dias, ele estava muito tranquilo, e que fazia de cinco dias a uma semana que não parava de chorar durante o dia. Esse desencontro se manifesta no choro intenso do filho e no desejo da mãe de sair, de não ficar naquela situação que a angustiava, em que é preciso entrar numa sintonia específica com o bebê: "[...] ele tá com 26 dias; eu tô 26 dias sem sair. Eu só saí três vezes pra pediatra; duas [para a] pediatra e uma [para a] ginecologista. Eu falei 'é sair, entrar no taxi, ir no consultório e voltar', porque cê fica agoniada, se vai chorar...". 
A situação parece lembrar a de alguém correndo uma maratona. Gabriela descreve a cena de forma jocosa, mas, a meu ver, denota o imenso sofrimento a que ela parece estar sujeita:

[...] eu vou dar peito, mas preciso sair porque a consulta era às onze. Eu falei "vai, mama aí, mama aí, arrota, nanan e vamo embora...". Eu cheguei eram quase três horas da tarde. Eu falei "nossa, eu preciso comer". Eu falei "ela tá dormindo, beleza. Pus no berço, deu cinco minutos, abriu um berreiro. Eu fritando hambúrguer. Eu falei "meu, o que que eu faço? O que eu faço?". Queimou o negócio. Volta pra cá, dá o peito, arrota, vai pra lá, agora eu como... [risos].

O encontro com o filho parece trazer à tona o colossal desamparo materno. É significado como assustador, desesperador, e me leva a pensar que, somada à sustentação oferecida por uma eficiente rede de apoio, a preocupação materna primária poderia servir de anteparo para o desamparo que se manifesta de forma intensa nesse período: "[...] teve uma semana que eu fiquei direto só com ele, né? E ai, como eu tava desesperada. Minha amiga falou 'eu vou deixar minha filha aqui. Dou de mamar e vou aí te ajudar. Cê tá sozinha!"”.

Ela parece ver como insuficiente a ajuda do marido nos cuidados com o filho. Diz que ele demora a fazer as coisas, o banho e a troca de fralda se prolongam muito.

Parece que Gabriela faz uma espécie de contagem regressiva para que o filho cresça depressa, pois as pessoas dizem que, aos três meses, tudo melhora, liberando-a do peso que sente. Há certa precipitação no tempo do filho, que parece não poder ser bebê: "[...] já vi todos os berçários, já pesquisei, já vi todos os berçários - isso, antes de nascer [...] porque eu já pesquisei [...] eu já vi todos os berçários [...] eu acho que, com sete meses, em janeiro, fevereiro, ele já vai pra berçário, então...".

Gabriela vai me contando das inúmeras perdas a que se sente sujeita. Ao amamentar o filho, sente um prejuízo que se assemelha a um roubo: "[...] de final de semana, eu gosto de pão francês, pão de padaria. Ele fala 'cê quer que eu vá lá buscar?' Eu quero... acordo... porque ele dorme, né? Seu pai dooorme. Sou eu que acordo ele. Eu digo 'tô com fome, tô com fome, que [nome do filho] tirou toda a minha comida'. Ele vai na padaria, compra, volta...". 
Gabriela conta que não se imaginava mãe. Ela precisa forjar o espaço psíquico para seu lugar materno. Suponho que haja um esforço para que isso aconteça, mas não diminui as dificuldades que ela vem encontrando na relação com o filho:

E, hoje em dia, eu vejo foto do parto, eu choro, sabe? Eu vejo quase uma vez por semana... Aí, cê chora, o olho enche de lágrima. Eu não esperava, e todas as minhas amigas que vêm aqui falam "putz, eu nunca imaginei você mãe". Nem eu, nem eu, de tão eu era baladeira pra caramba, toda não sei quê, de rua, de sair, de voltar... Todo mundo olha pra mim, ficam vendo eu amamentando "Nossa! Eu não imaginava você mãe". Eu falo "acho que nem eu", mas, putz, é supergostoso. É gostoso, mas às vezes como você consegue cuidar?

Sua preocupação em educar o filho parece representar o peso de fazê-lo viver, e ela revela certa dúvida sobre contar com o marido nessa tarefa, e o receio de ter que ceder:

Isso é mais meu medo: a responsabilidade de educar, de como eu vou fazer, sabe? Será que eu vou seguir o que eu acho ou o que o marido. Como é que vai ser, eu e ele juntos, sabe? Ele fala... Aí, o que eu penso também... Ele fica muito mais fora do que eu, e às vezes vai ser a Gabriela brava: "Não, [nome do filho], você não vai poder fazer isso". E ele que nunca tá nada, que só chega à noite. "Não, querida, vai lá, deixa ele fazer...". Não, a gente vai ter que entrar num consenso aí, pra saber o que fazer com ele, né? Porque... não sei...

Gabriela parece ressentir-se dos espaços de intersecção que as relações operam, acrescidas a seu novo papel materno.

\section{SEGUNDO ENCONTRO APÓS O PARTO}

\section{Um bebê batata quente...}

A entrevista foi realizada quando o bebê estava com quatro meses e uma semana - um atraso significativo em relação ao prazo em que gostaríamos de ter voltado a ver a dupla mãe-bebê. Mais uma vez, tivemos dificuldade para marcar o encontro, dessa vez, em grande parte devido à viagem que a família fez à terra natal dos avós paternos. 
Conversamos no hall de entrada do prédio de Gabriela, porque seu marido estava trabalhando em casa. Senti certo desconforto e me perguntei porque o marido não poderia participar do encontro, ou só ficar por perto.

Gabriela reclama de o bebê ainda chorar muito. Mal ela o coloca no carrinho, e ele começa a chorar. Depois de mamar, chora uns 40 minutos e engasga muito. Diz que esse choro é manha, malandragem, e que pode ter também um pouco de refluxo. Depois, vai ficando mais claro que as dificuldades entre mãe e filho ainda perduram.

Ela me conta que o filho ficou doente. Teve bronquiolite, ficou internado cinco dias com febre alta, e os médicos demoraram a diagnosticar, mas ela intuía que havia alguma coisa errada com a criança. $O$ casal se angustiou no atendimento, no hospital, com a incerteza sobre a saúde do bebê e com o fato de ele ter sido submetido a vários exames, mostrando como pode ser opressivo e mesmo brutal cuidar praticamente sozinha de um bebê nos primeiros tempos de vida, mesmo num caso como o do filho de Gabriela, que nasceu bem, sem nenhuma intercorrência.

É interessante pensar como esse adoecimento reflete a forma como Gabriela parece sentir-se internamente, a respeito das reverberações da chegada do filho e da transformação subjetiva imposta por sua presença. $O$ tema das perdas aparece novamente em sua fala: parece dizer que sua vida não the pertence mais, que o bebê a levou embora: "Eu fiquei supernervosa! Porque é um pequeninho, né? Porque agora minha vida está em torno dele, né? Realmente, eu tô 100\% [nome do filho]. $100 \%$, eu não faço nada....".

O filho é sentido como alguém que demanda muito e que suga sua vida. Seu narcisismo não parece ter sido transvasado, mas arrancado a força: "E eu queria voltar a ter vida, porque eu não tenho vida! Quer dizer, tenho! Não vou dizer que não tenho, mas, assim, eu tô há quatro meses - eu e o meu marido, a gente só vive em função do bebê....".

Parece sentir-se completamente exaurida, roubada pelo filho. Enquanto ele está esperto e crescendo, ela perde. Não pode contar muito com os ganhos da maternidade, com o prazer envolvido nessa relação. Talvez sinta as perdas mais do 
que os ganhos: "É superesperto... eu tô supercansada, não é?... Eu não consigo fazer mais nada, minha vida tá... Todo mundo que me vê fala 'nossa, você tá magra!' Eu falo ‘ai, gente, eu não sei...'”.

As perdas parecem ser vivamente sentidas no próprio corpo de Gabriela. Desde a entrevista anterior, ela se queixa de que seu corpo mudou, apesar de ter perdido peso rapidamente depois do nascimento do filho. Nessa entrevista, volta a falar sobre isso e conta, aterrorizada, a queda acentuada de cabelos. Complementa com um tom de sacrifício, refletindo a profunda metamorfose a que se vê sujeita: "Acho que a gente devia ganhar umas medalhas, o corpo muda tudo, o cabelo [...] eu não gosto da cara que eu tô...".

Gabriela parece não poder contar com sua capacidade de ir se conectando com o bebê e, nessa medida, ir conhecendo-o. Precisa contar sempre com o que a pediatra diz que deve ser feito; não pode ser fruto de sua própria experiência. Esse fato pode agravar ainda mais o desencontro, e me parece que representa uma espécie de retroalimentação negativa, na qual fica prejudicada a valorização de seu lugar materno, da potência que a mãe pode sentir quando alimentada por uma relação que envolve prazer.

O desencontro com o filho se estende no tempo. A sintonia entre ela e o bebê parece prejudicada, como se eles não conseguissem acertar o tom. Não vejo um quadro de depressão clássica, mas há sofrimento, há certa impossibilidade exatamente de deprimir saudavelmente e tentar entrar em contato com o filho, entrar em outro ritmo, no compasso de um bebê.

Gabriela tem certa dificuldade de ver o filho como um ser pequeno: trata-o como muito mais velho, talvez pela constatação da dependência da criança, que a apavora, e da percepção de sua importância para o bebê. A falta de uma rede eficiente de sustentação da relação de Gabriela com a criança agrava ainda mais o quadro. Ela não pode contar com um terceiro que a auxilie e procura maneiras de se livrar desse lugar penoso e aterrorizante.

A busca de um berçário desde a gestação pode representar uma forma de obter certo alívio, bem como uma tentativa de cuidar da melhor forma possível do 
filho, pois critica as babás que ela acompanha no prédio onde mora, que ficam o dia inteiro no celular, alheias às crianças de que cuidam.

A desarmonia transborda as fronteiras da relação mãe-bebê e alcança o pai: os impactos são sentidos pela família como um todo. Gabriela acredita que o marido tinha que saber cuidar do filho e, quando ele questiona a razão de seu cansaço, ela reage veementemente, numa espécie de "Lei de Talião":

"Não entendo por que você fica cansada". Aí, num dia no final de semana... "agora ele vai sentir"... Chorou, vai pra ele. Vai trocar fralda, vai pra ele. Chegou no final, "ai, tô morrendo de dor nas costas, tô tão cansado!" Eu falei "engraçado, né? Isso porque você só fez um dia. Imagina se você faz cinco"... "Realmente, você deve estar muito cansada!" Às vezes, eu faço de propósito!

Seu desamparo é agravado pela falta de uma compreensão empática do sofrimento ao qual fica sujeita:

Eu sei que é ruim, mas vê que eu também tô sofrendo. Teve um dia que eu fiquei cinco horas com ele no colo! Que ele não queria ficar... Não tinha jeito nenhum de pôr no carrinho, não sei quê, ele ficou no colo... Eu falei "vem". Eram seis horas da tarde, que era uma hora em que ele já pode sair do trabalho. "Vem, porque eu já não aguento mais!" Já fiquei dia sem tomar banho...

Percebi que um movimento mais harmônico pôde surgir na família na viagem que fizeram. O padrão de choro e de sono mudou completamente. Gabriela pareceu estar menos sobrecarregada, o que reverberou positivamente não só nela, como na criança. No entanto, assim que voltaram para casa, o quadro anterior voltou a se instalar.

Talvez a dificuldade de abrir mão dos investimentos anteriores ao nascimento do bebê - desinvestir momentaneamente de sua vida anterior para regredir e investir no filho, certa impossibilidade de adoecer saudavelmente, entrar no estado de preocupação materna primária - e de chorar as perdas decorrentes desse nascimento e elaborá-las com um baby blues tenha dificultado a experiência de ganhar prazer na relação, com a possibilidade de conectar-se sensivelmente à maternidade e ao bebê. Arrastando o desencontro no tempo, Gabriela ficou com um bebê "batata quente"... 


\section{TERCEIRO ENCONTRO APÓS O PARTO}

\section{Preenchendo espaços vazios...}

Essa entrevista também foi atrasada: o bebê tinha cerca de seis meses.

Gabriela parece não ter conseguido mudar muito as coisas; elas continuam as mesmas: "eu continuo supercansada, assim... Não voltei a ter vida ainda, ele vai fazer seis meses!".

A hipótese de que Gabriela se sente esvaziada pelo filho, o qual the arranca a vida, dificultando uma retroalimentação libidinal, e de que seu narcisismo não transvasa facilmente parece confirmada também nesse encontro: "Eu tô louca pra voltar a ter vida!". Ela indica uma angústia desorganizadora com a vinda do bebê, refletida na perda de sua identidade anterior e talvez numa dificuldade de construir uma nova, sem tanta dor.

A troca de prazer no contato com o bebê talvez esteja prejudicada, mas, nesse encontro, pode aparecer, no momento em que me inclui e me mostra como ele agora interage mais, como sabe sentar e brincar etc. Acredito que isso se possa refletir num ganho de prazer na relação.

Quando pergunto como estão o filho e ela, como ela sente o relacionamento com ele, Gabriela conta que as pessoas dizem que ele não tira os olhos dela. Parece não sentir plenamente sua importância para o bebê - precisa que os outros a apontem -, possivelmente porque não está suficientemente livre para sentir-se intimamente conectada com ele.

Pelo que eu percebo das pessoas, quando me veem e dizem "nossa, ele não tira os olhos de você". Mas eu acho que é por eu ficar com ele o dia inteiro, né? Então, assim, a referência dele é - ele sabe que eu sou a mãe - a mãe dele, mas ainda não... eu leio que [em dado momento] ele vai dar os bracinhos, né? Mas ainda não tá nesse período, assim...

Sua fala denota duvida quanto à força da ligação entre ela e o bebê. $O$ bebê parece ligado, mas ela não consegue sentir e se beneficiar disso, talvez por projeção de suas próprias dificuldades. 
Suponho uma dificuldade de Gabriela estar integralmente presente no contato. A impaciência que se manifesta em seus atos e falas sugere que ela nunca está onde deveria: a pressa, a necessidade de preenchimento, as falas sobre as diferenças culturais entre ela e o marido. Penso que um exemplo emblemático disso é o plano de atividades para si mesma e para o filho num futuro próximo: "Não sei se é muita atividade pra criança. Aí, não sei. Eu falei 'vou pôr no berçário, e, de manhã, duas vezes por semana, vou ver natação'. Não sei se é muito. Não sei, de manhã, meu... O que a gente vai ficar fazendo, agora, no verão, né?".

Parece haver a necessidade de aplacar a angústia com atividades, e ficar em casa simbolizaria certo desespero:

Eu falei "não, é que eu sou de rua, ficar em casa... me... não sei, ficar em casa, mas desde... não sei, não sei ficar em casa. Eu gosto de rua, eu gosto de ver gente, eu gosto de ver coisa, não me deixa em casa! Eu não sei ficar em casa!" Cê vai me ver aqui com ele, aí, depois eu vou pra lá, eu vou pra cá. Ontem mesmo, parou de chover, eu falei "e aí? Vam'embora, vamo descer!" Fui, dei uma volta de quinze minutos e voltei! "Parou a chuva, parou a chuva! Vam'mbora!" E ele adora. Põe no carrinho, bate as pernas! Eu não sei se ele vai ser pior do que eu! [risos]

Parece estar num permanente teste de limites, vendo até onde consegue suportar. Não conta com ajuda suficiente, não está satisfeita com a pessoa que tem para auxiliá-la em casa, mas não consegue cobrá-la para que trabalhe mais e melhor, e também não consegue procurar alternativas.

Suponho que Gabriela fica sobrecarregada e sozinha para lidar com tantas coisas que demanda a vinda de um filho. Pensa em voltar a trabalhar assim que o bebê for para o berçário e acredita que será em breve.

O casal pensava inicialmente em ter outro filho logo depois do primeiro. $\mathrm{O}$ marido continua querendo concretizar esse projeto, mas ela o rejeita veementemente. Gabriela alega que seria insensato, mas sua fala indica sobretudo que pode haver certa despersonificação. Ela não é mais a mesma, foi profundamente atingida pela experiência da maternidade:

[...] e realmente eu tinha pensado em ter logo em seguida. Agora, já mudei de ideia... porque eu tinha falado, na quarentena "quando ele fizer um ano, não sei o quê... emendar, não sei o que [...]. Meu marido "ah, não sei o quê"... Eu falei "porque não é você... não é você"... Teu corpo - meu - não volta ao normal. Teu cabelo - meu - cai. Não é você!" Deixa eu me restabelecer um 
pouco mais, aí, eu penso no segundo... Porque, nossa! Não sei se é egoísmo meu, mas, assim [...] Porque eu queria, sabe?, poder sair com seu marido... eu não...

No contato com Gabriela, percebo que ela pode fazer uma interessante transferência comigo. Parece sentir o término de nosso contato e tenta prolongá-lo com mensagens de texto depois de cerca de dois meses do nosso último encontro presencial: me conta algumas coisas sobre o bebê, entre eles, como tinham sido a passagem para a alimentação pastosa e a entrada no berçário. Depois disso, não recebo mais notícias dela. Antes, me enviara mensagens desejando Boas Festas.

Penso no quanto foi difícil para Gabriela a transição para a parentalidade, agravada por uma rede de sustentação insuficiente. Não tendo sido suficientemente amparada, ela viveu essa transição muito duramente, sem poder contar com alguma ajuda para ressignificar e transformar seu desejo de ter um filho num desejo de ser mãe de seu filho.

\section{VANESSA}

ENCONTRO GESTACIONAL

\section{Mãe $100 \%$ de um bebê $100 \%$}

Vanessa foi encaminhada por uma médica pediatra que soube do estudo. Depois de esclarecida sobre a pesquisa, ela parecia ainda mais animada a participar. Diz ainda que seu marido gosta de participar de todas as consultas referentes ao bebê e que o período da manhã seria melhor para contarmos com sua presença.

Embora eu considere a presença do pai um fator importantíssimo para avaliar um horizonte mais ampliado do fenômeno, essa inclusão não fazia parte da proposta inicial do estudo, mas, nesse caso, como a demanda partiu da participante, não achei prudente rejeitá-la e a acolhi como uma possível variável de seu movimento psíquico que, somada às outras, talvez compusesse um entendimento melhor de sua dinâmica. 
O tom eufórico de Vanessa perpassou toda a entrevista. Ela parecia estar em pleno transbordamento, que só tomava outro tom quando falava na relação tumultuada com sua família de origem.

Sobre sua gestação, Vanessa revela certa surpresa, pois estava sendo bastante tranquila, desmentindo a crença de que as coisas não seriam fáceis e de que ela ficaria muito limitada. Essa impressão parece dever-se à experiência da gravidez de sua irmã, que foi tumultuada.

É o marido que nos conta primeiramente como a gestação se insere no contexto da vida do casal. Estavam juntos há dez anos, casados há quatro e tentando engravidar nos últimos dois. Vanessa fala sobre o longo e sofrido processo até a concretização do desejo do casal.

A demora da espera - pelo casal e pela família - a gravidez inspirou ansiedade e frustração em todos. Depois de tantas tentativas, quando soube que estava grávida, Vanessa custou a acreditar que era verdade, mas, apesar do conturbado período pré-gravidez, estão vivendo a gravidez de forma tranquila.

No início, o marido parece se sentir um pouco excluído da entrevista, mas depois é ele quem fala sobre as dificuldades, num tom contido e controlado, que parece pretender que cada coisa ocupe seu devido lugar. Quando fica mais à vontade, introduz questões importantes.

Contou que ele nasceu quando sua mãe tinha 16 anos. Sua família de origem é sentida como uma presença invasiva, e ele conta da necessidade de se afastar deles para crescer pessoalmente.

O casal disse que a noticia da gestação causou certa surpresa, e o pai sentiu também alguma insegurança: "será que vou dar conta?". Vanessa conta que, a isso, somaram-se uma certa confusão e uma questão semelhante mas qualitativamente diferente - "será que eu vou dar conta de tudo?" -, talvez indicando a idealização de seu lugar materno, a expectativa de ser uma mãe $100 \%$, o que se confirmou nos encontros posteriores. 
O nome do filho é escolhido por Vanessa, mas só depois da anuência de sua mãe a um dos nomes cogitados. $O$ sexo do bebê é o que o casal queria, o que os deixou ainda mais felizes.

O bebê parece ser alvo de grande investimento dos pais, especialmente materno. Ele é descrito como um bebê grande, responsivo e muito parecido com a mãe. A princípio, me pergunto de que bebê se trata, esse da gestação de Vanessa? Penso primeiramente no mecanismo esperado de antecipação, um elemento importante para os pais forjarem um lugar em seu psiquismo, mas esse não parece ser o único elemento.

Há a reiteração de que o bebê é "igual" a ela e, portanto, um papel fortemente marcado na triangulação, na qual Vanessa não aceita ser "posta de lado". Outro elemento importante parece ser que o filho é tratado como já conhecido, muito familiar, e como se ele soubesse o que quer. Muitas falas de Vanessa indicam que, ao lado de seu investimento e da desejada antecipação do bebê, pode haver um bebê muito idealizado, fruto do narcisismo materno: "Ele é um ótimo filho!".

Não podemos perder de vista que o narcisismo dos pais é reavivado no momento de terem um filho, que alimentará sua libidinização, mas, nesse caso, parece tratar-se de um incremento desse narcisismo materno, o que pode obstar a separação dessa imagem idealizada do bebê e dela mesma em seu papel materno.

\section{PRIMEIRO ENCONTRO APÓS O PARTO}

\section{Sobre os extravios da maternidade}

O pai também esteve em grande parte dessa entrevista, que aconteceu no quarto da criança, que, por sua vez, dormiu quase todo o tempo no colo da mãe.

Planejavam ter o filho em determinada maternidade, mas houve um contratempo com o plano de saúde, o que teve grande impacto, também pelo risco de o parto não ser feito pelo médico que tinha acompanhado o pré-natal. 
O marido é uma importante figura de apoio. Vanessa conta muito com sua presença e parece precisar dele para passar por experiências que the exigem muito. A partir do momento em que ele entrou na sala de parto, ela foi conseguindo se acalmar. Ele participou ativamente do parto: "ele fazia tudo chorando igual a uma criança, superemocionado!".

O parto representa um divisor de águas, e a emoção do nascimento do filho é "algo sem igual". No entanto, ele parece simbolizar uma experiência de fronteira: implica o risco da transição do bebê em segurança na barriga de Vanessa para o bebê que precisa sair e viver. A representação da vida e da morte está cruamente envolvida nesse momento de passagem, inspirando a dúvida sobre se a chegada do bebê não seria prematura, uma vez que, tendo marcado a cesárea, era ela que precipitava a vinda do filho: "[...] mas eu ficava apreensiva o tempo todo: 'será que ele tá bem? será que vai nascer bem [...] Será que o pulmãozinho dele tá formadinho, será que vai conseguir respirar assim que sair', né?"

Talvez Vanessa desejasse prolongar a gravidez e adiar esse momento fronteiriço e angustiante, pois, para ela, estar grávida foi uma experiência prazerosa, vivenciada com um sentimento de plenitude que o parto veio interromper: "Nossa! No parto, eu tava superapreensiva, no início, porque chega assim na hora dá vontade de correr e falar "espera mais um pouquinho dentro... deixa mais um pouquinho aqui dentro'...".

O medo de perder o filho aparece repetidas vezes, sinalizando que imperava no parto, e, apesar de ter ficado mais tranquila depois dele, disse ao marido: "fica de olho nele, se colocaram a pulseirinha; toda aquela insegurança; eu falava 'marca o rostinho dele'. Aí, que ele veio e trouxe ele pra mim, nossa!".

No processo de transição que o nascimento representa, a outra face do medo de perder pode ser uma espécie de angústia de separação que a fala de Vanessa exemplifica: "Eu ficava lá embaixo, agoniada. Eu quero ver meu filho, né?... Eu ficava agoniada pra ficar com ele...".

A fala "Quando terminou meu parto..." me parece interessante, pois indica uma simultaneidade: a mãe nasce no parto do filho. Presumo que é na tessitura 
entre seu desamparo e o de seu filho que se darão as relações, construção contínua em torno de todo o processo de tornar-se mãe.

Vanessa fala da emoção e da crença no estabelecimento e no fortalecimento do vínculo com o filho:

Ele veio chorando e, quando eu conversei com ele, ele parou de chorar. Eu conversava muito com ele na barriga, e uma das coisas que eu dizia muito é que não era justo que eu não conseguia beijar ele [risos]... Eu dizia "quando você nascer, a mamãe vai descontar todos os beijinhos, tá bom?" Quando ele nasceu, a primeira coisa que eu fiz foi beijar ele. Eu lembrei ele disso, aí ele lembrou, ele ficou quietinho. Eu achei isso o máximo!

A experiência do nascimento do bebê e dela como mãe têm várias faces, inclusive a perda das certezas e um caminho rumo ao incerto, próprio da natureza humana e território do desamparo:

Junto com essa emoção do parto, de... ficar superfeliz, né? Colocar uma coisa dessa no mundo, até eu falei... "como a gente conseguiu fazer uma coisa tão bonita?" [risos] [...] mas, junto com essa sensação de felicidade, tudo, vem essa insegurança: "será que eu vou dar conta, será que eu vou estar sempre fazendo o melhor pra ele?" Porque é uma sensação... é um serzinho que depende de você, não sabe falar, não sabe... assim, ele até sabe de algum jeito mostrar algumas coisas, né? Com choro, né? Às vezes com algum olharzinho, você percebe que ele tá mais angustiado, que ele tá com calor e tudo, mas é muito novo, né?

Sob o império de seu próprio narcisismo, não gostaria que o filho sofresse, indicando sua insuficiência humana, mas tenta se convencer de que algumas experiências são inerentes à vida, ao mesmo tempo em que anuncia os extravios que a maternidade comporta: "[...] por mim, meu filho não chorava, só sorria. Mas eu vou fazer o quê? Ele precisa chorar [...] faz parte da vida...".

Resistindo à perda do bebê que estava dentro de si, reage com uma vontade de ser uma mamãe-canguru, para não se separar do filho, prenunciando a dor dessa passagem de um bebê interno idealizado para um externo, real e demandante, que exige sem tréguas a assunção de seu lugar materno:

[...] mas, ai, é uma sensação assim, que parece que você quer levar ele grudado em você a vida toda, sabe? Não desgrudar, até eu falei pro [nome do marido] "ah, agora a gente passa a entender melhor as nossas mães, que não dormem à noite esperando a gente chegar da faculdade... 
As falas do casal vão simbolizando cada vez mais as tensões a que se sentem sujeitos. O pai fala num "acúmulo de funções": ele tem ajudado nos cuidados com o bebê, com as compras e com o banco, e ainda é ele que, mais de uma vez, aponta a intensidade da situação, dizendo das crises de choro e de insegurança de Vanessa, que não havia na gestação mas que surgiram com força após o parto. Ela diz: "[...] abriu-se a torneirinha do choro...". Algumas vezes, o pai teve que acudir a mãe e o filho: se o bebê começava chorar, ela também chorava. De acordo com o marido, ela chorava por qualquer coisa.

Contam uma experiência forte, quando o bebê engasgou devido ao excesso de leite e por sua reduzida capacidade de digestão estomacal, chegando a ficar sufocado. O casal chegou a levá-lo ao pronto-socorro para ver se tudo corria bem, pois a mãe teve que fazer uma manobra de emergência para que o filho voltasse a respirar normalmente. Os engasgos se repetiram algumas vezes, deixando Vanessa muito angustiada e fazendo-a reviver sentimentos intensos de perda; sempre que o bebê chorava, ela ficava com muito medo de perdê-lo.

A fala da mãe indica o susto de ter sido pega desprevenida, pois se preparara para amamentar - ela investiu muito nisso. Disse que tudo ia bem, até ocorrer o engasgo: "Eu tremia... Eu falo pra ele, eu falo 'não é justo, né?' Ele passou todos os nove meses bem na barriga, a gente esperou por ele e tudo, e, do nada, um susto desses..." É o impacto decorrente da angústia pela possibilidade de morte, de perda de alguém tão desejado, que acaba de nascer.

O desamparo da mãe surge à medida que ela percebe a fragilidade da vida, que há um risco de morte na interface da vida. $O$ excedente de angústia pode ser compreendido por uma ameaça real ou pela necessária morte simbólica no momento em que o filho real entra em sua vida. O descompasso entre mãe e filho é representado pelo excesso de leite e pela dificuldade do bebê de absorvê-lo, engasgando e sufocando.

Deixar de ter o bebê da barriga parece recriar o desamparo materno: tudo pode acontecer. O narcisismo de Vanessa sofre um duro golpe, o que the exige desidealizar seu filho e sua própria imagem como mãe. 
Só ao marido ela permite que a ajude nos cuidados com o bebê, vetando qualquer outra pessoa, mesmo sua mãe, que segundo diz, a deixou angustiada e que só atrapalhou. Quanto ao marido, "a gente faz tudo sempre junto".

O casal fala numa necessidade de adaptação entre os três membros da família, e isso talvez seja realmente parte do processo de elaboração que o blues envolve: "[...] adaptação à situação nova... eu choro mesmo, porque eu não sei o que está acontecendo, sabe?"

As vivências de Vanessa sugerem que o impacto do nascimento é o choque causado pelas perdas, inclusive das idealizações, e sobretudo à falta de certezas e garantias, inerente à vida. Talvez o blues se refira ao desamparo humano, ao fato de a vida não ter garantias, o que aparece sem disfarces com a chegada do filho, marcando fortemente esse período. A mãe passa a ser responsável por fazer viver um ser, mas sob o domínio do sempre inesperado viver humano.

Para Vanessa, perder a gravidez representa perder um ambiente confortável e gostoso, contrastando com o puerpério imediato, vivenciado como o universo fora das certezas, onde a mãe se vê desalojada. Ao mesmo tempo, ela afirma que "vai caminhando, apesar de tudo":

Eu fiquei mais chorosa, eu falei pra pediatra "nossa! A progesterona que não
veio na gravidez pra me fazer chorar, veio agora, porque..." É um medo de
perda muito grande! Eu não sei o quanto é normal, enfim... acho que, até pela
história dele, que a gente esperou pra ter um... esperou bastante tempo pra
ter ele, esperou bastante tempo. Mas, assim, eu... quando ele engasga, meu
coração vai na boca!

Apesar das perdas, o casal identifica também os ganhos na relação, após a vinda do filho, e o quanto se emocionam com ele.

\section{SEGUNDO ENCONTRO APÓS O PARTO}

\section{Sobre as incertezas da vida}

Depois de um mês exato da primeira entrevista puerperal, recebo a seguinte mensagem do marido de Vanessa em meu celular: "Boa noite, Dra., Eu, a Vanessa 
e, é claro, [nome do bebê] gostaríamos de saber quando será sua próxima visita. Sem mais". Um minuto mais tarde, antes mesmo de eu responder, a mensagem é reenviada. Respondo perguntando sobre a possibilidade de nos encontrarmos durante a semana, e logo chega a resposta afirmativa.

Penso que esse movimento é um pedido, me levando a supor que esses encontros têm um lugar privilegiado, seja para o casal, seja para Vanessa individualmente.

A essa entrevista, o pai só esteve presente no início.

Vanessa conta que tudo corria bem até dois dias antes de nosso encontro, quando o bebê ficou acordado horas seguidas, choroso e só querendo ficar no colo. Ela não sabe muito bem a que atribuir esse incômodo; cogita a vacina tomada na maternidade, que drenava pus até dias antes e que agora estava cicatrizando, ou cólicas. Por isso, houve uma desorganização, e o bebê quer mamar o tempo todo, a ponto de não dar tempo de suas mamas voltarem a se encher, o que a entristece muito.

Conta que viviam numa certa calmaria, pois os engasgos que a preocupavam eram agora menos intensos e frequentes, e o próprio bebê sabia como se proteger deles. Atribui-os não só à dificuldade de sugar que ele tinha no início, mas ao fato, recém-descoberto, de que o freio da língua do filho era muito para a frente, o que pode aumentar essa dificuldade.

Vanessa percebeu como é difícil enfrentar as demandas do bebê e se sente extenuada, transtornada e sujeita a uma tensão sem tréguas:

Tô acabada! Eu tava falando pra ele, tem dia que é um cansaço físico, assim, e mental tão grande, que dá vontade de sair correndo! Ai, me dá umas férias! [risos] mas... eu falei pra ele "eu não sei como esse povo que tem filho que não é planejado aguenta". Porque a gente se prepara, que quer muito, não sei o quê, tem esse cansaço tão grande! Imagina esse povo que tem um filho atrás do outro...

Sua vivência aponta a lacuna entre o desejo de ter um filho, tingido com as cores da idealização e do narcisismo, e ser mãe desse filho na realidade, com as demandas e com o custo emocional desse caminho: uma mãe cujo leite não jorra 
mais, ou fica escasso, uma mãe que a princípio não sabe e precisa aprender, que quer férias e tem vontade de sair correndo.

Vanessa fala numa espécie de reviravolta materna que a pega desprevenida, deixando sua vida de pernas para o ar, provocando um turbilhão de sensações e emoções:

Você não consegue sentar para comer, você não consegue tomar banho [risos], não consegue dormir. Eu não consigo trocar de roupa. Eu falei para ele, tem dias, Cristiane, que eu vou escovar os dentes às dez horas da noite, na hora que eu tô tomando banho! [...]. Eu não sei, é um turbilhão de tanta coisa, que eu não consigo ver nada no fim do túnel... [risos].

Transcorrido algum tempo da entrevista, a dupla parece se desorganizar no momento em que o pai volta a trabalhar, pois ele havia tirado férias assim que o filho nasceu, justamente para ajudar nos cuidados com ele. Assim, Vanessa parece ter sentido a ausência do marido, ficando sozinha com o bebê grande parte do dia. O marido é uma figura fundamental para Vanessa; além de ser muito participativo e de apoiá-la, ela só deixe que ele a ajude. Quando sua mãe está, uma vez por semana, ela só é autorizada a cuidar da casa e a providenciar alimentação.

As desarmonias são sentidas na família como um todo, e os impactos reverberam no choro do filho e da mãe. Em seu turno, o pai parece ficar sobrecarregado e precisa acudi-los a ambos. Vanessa se frustra por não conseguir "amamentar exclusivamente e até pelo menos seis meses", como a princípio planejava. Leite escasso não fazia parte de seus planos.

No entanto, suponho que o fato de o filho ficar grudado em seu peito seja fruto de um desejo materno, semelhante ao já mencionado da mãe-canguru. Os substitutos não são bem-vindos: parece que Vanessa nem cogita a chupeta.

Com a demanda incessante, ela precisa diminuir suas expectativas em relação a sua função materna. Diz que está tão cansada, que não pega mais o filho no primeiro choro, deixando de ser $100 \%$ presente e $100 \%$ atenta. 
Pede uma intervenção minha. Me inclui na trama querendo saber o que pode estar acontecendo e se deve ou não deixá-lo chorar. Diz à pediatra que eu sou sua psicóloga e me inclui na conversa com o filho, diálogo falado em "manhês".

As surpresas por as coisas não correrem conforme o imaginado são contínuas. Tudo é novo, e o filho não é seu velho conhecido, como ela supunha na gestação. No entanto, Vanessa parece fazer alguns deslizamentos - "uma hora é uma coisa, outra hora é outra" - e se referir aos ritmos "dessas oscilações, oscila demais!". O ideal é sem ritmos, sem curvas, em que imperam a estabilidade e as retas. Só o idealizado é certo, o resto é incerto. Parece tangenciar a angústia que é sentir-se tão desamparada nesse momento.

Mas também parece dizer que nem tudo está perdido: recuperou-se bem da cesárea e, apesar dos desarranjos, o bebê está ganhando peso e se desenvolvendo normalmente, o que concorre para acalmar a mãe.

Sinto uma diferença significativa no clima emocional do encontro, que repercute na possibilidade de Vanessa pensar um pouco mais e ficar um pouco mais tranquila. Talvez ela já possa compreender que não é uma mãe 100\% e caminhar rumo a uma metabolização da experiência, talvez a uma elaboração:

Eu também sou do tipo que me cobro demais. Então, eu sempre quero tá fazendo o melhor pra ele, o melhor pra mim, o melhor pra casa, o melhor pro marido, e assim vai, entendeu? E aí, nesse meio tempo, a gente não percebe, aí a gente vai se esgotando, e, quando vê, o cansaço vem de uma vez só. Eu me cobro muito também. Às vezes, eu falo assim "eu tinha que saber", sabe assim? Eu tinha que saber o que está acontecendo com ele pra eu poder resolver! Mas não é assim, né? Mesmo sabendo que não é assim, eu me cobro, uma coisa que não dá pra controlar, a cobrança.

Saber ser mãe antes da experiência é outra face da idealização da maternidade nela, fortalecida pela cultura sobre o inatismo do amor materno, pelo qual toda mãe sabe o que fazer logo que seu filho nasce, mesmo sem ter tido experiência nenhuma com outras crianças e sem apoio ou auxílio de outras mães. 
Depois que eu desliguei o gravador, Vanessa oferece a chupeta ao bebê e se surpreende muito quando ele a aceita; diz que é porque eu estou ali. O bebê dorme em seguida. Ela disse que ele não pegava chupeta, e compreendi que poderia haver uma resistência de sua parte, correndo o risco de se sentir trocada. Ao se despedir, ela me agradece. Fico especialmente tocada com sua fala: apesar de saber que nossos encontros faziam parte de meu protocolo de pesquisa, ela achava muito bom quando podia contar com minha presença.

\section{TERCEIRO ENCONTRO APÓS O PARTO}

\section{Como dói crescer!}

Nesse encontro, estávamos apenas Vanessa e eu. O bebê dormia em outro cômodo da casa e só veio perto do fim da entrevista. É a primeira vez que ela me recebe com roupa de passeio; nas outras duas vezes estava com roupas de dormir.

Percebo uma mudança em seu tom de voz, mais baixo do que nos outros encontros. Penso que pode refletir talvez um movimento mais deprimido, mas, ao mesmo tempo, tinha abandonado o pijama.

Quando pergunto como estavam, ela me responde que todos bem, pois agora o bebê dormia durante um bom tempo, o que também Ihe permitia descansar, melhorando seu estado geral.

Sentiu que as coisas começaram a mudar depois que levantou a hipótese de que o choro incessante e a falta de sono do bebê fossem fome. Introduziu leite artificial para complementar o materno, e vem ocorrendo uma substituição gradativa. Agora, é o leite materno que complementa o outro, mas ela não deixa de amamentar para não ficar completamente sem leite.

Parece dizer do duro aprendizado com o bebê e da perda de não poder amamentar: o plano da mãe $100 \%$ deu lugar a uma mãe que se procura adequar às necessidades do filho e também às próprias. A mãe idealizada, cheia de leite - com o qual ele se engasgava -, dá vez a uma "mãe insuficiente", ou talvez a uma mãe 
real procurando se adaptar a essa realidade de que ela não gosta, mas para a qual não vê alternativa:

[...] é que eu achava, quando eu tava grávida, que era tudo cor de rosa, né? Achava que tudo era perfeito e tudo ia ser assim, numeradinho - 1, 2, 3, 4, 5, 6 -, enfileiradinho, que não ia ter esses contratempos, mas... teve, e eu tô me adaptando, aos trancos e barrancos...

Fala ainda sobre ter o filho grudado no colo:

[...] só é que ele quer ficar grudado comigo no colo, só quer ficar comigo grudado no colo, mas, na medida do possível, eu tiro ele, deixo... enquanto ele não chora, eu deixo ele cinco minutos no berço. Aí, ele chorou no berço, eu ponho cinco minutos no trocador. Aí, ele chora no trocador, aí eu vou fazendo isso. Ponho um pouquinho na cama. Ele chorou na cama, eu ponho no bebê-conforto, e assim vai... Aí, tem hora que, assim, a maioria do dia, ele quer ficar comigo no colo...

Outra fala aponta a questão do grude ou da separação e indiferenciação:

[...] eu vou pôr um velcro em você e pôr um velcro na mamãe, e vou grudar você comigo, porque assim, quem sabe?, resolve o problema... mas achar ruim - dizer pra você que eu acho ruim -, eu não acho ruim, não! De jeito nenhum! Mas eu tenho... sabe assim, a gente fica naquela encanação "pô, até onde eu tô fazendo um bem pra ele, até eu tô fazendo um mal?

A relação caminha, mas parece fortemente tingida com as cores das projeções maternas. Há uma comunicação baseada no olhar, mas com uma característica algo persecutória, na qual Vanessa provavelmente acione um mecanismo de projeção. Indica uma espécie de indiferenciação entre ela e o filho, que acredita ser muito parecido com ela: é bravo como ela, não consegue disfarçar o que está sentindo e um grude:

No peito mesmo, tipo assim, secava, parava, não tinha nada, ele franzia a sobrancelha. Eu falo "até nisso ele me puxou", porque eu não consigo disfarçar as coisas. Às vezes, eu quero disfarçar, mas eu faço caras e bocas sem perceber. E ele franzia o olho assim, e olhava com aquele olhar bravo, sabe? Tipo assim "por que você não me dá? Me dá, ele é meu!" Sabe? Então, já olhava, e hoje eu também percebo isso, que tem alguns horários que ele dá um olhar apaixonado, sabe? [...] Eu acho impressionante!

Parece localizar o amor e o ódio no filho: "Com o peito também, eu me sentia supermal, porque eu falava 'mas, filho, você tem que entender que não é porque a mamãe não quer'... Eu ficava explicando pra ele, sabe?" 
Considera agora que não sabe tudo sobre seu filho, como imaginava na gravidez, quando sua fala indicava que o sentia como um velho conhecido. Sair para o mundo implica várias questões: a perda do ambiente protegido, mas também a necessidade de perceber as necessidades reais do bebê, de ir conhecendo-o na realidade da experiência com ele: "Então, eu ainda não sei sair com ele. Essa é a realidade. Eu sei arrumar a mala e tudo, o que precisa ir, tal, não sei que... mas eu ainda não sei, assim, me portar, me comportar, levar ele e toda situação, sabe?"

Vanessa fala sobre a operação de descentramento psíquico necessária para exercer suas funções maternas e em como, a partir do nascimento, não pode mais considerar apenas a si própria. Agora, devendo incluir o bebê em sua vida, o que talvez desencadeie certa ansiedade:

É, então, aí, eu já não sei sair com ele, já não sei... porque agora eu tenho que me adaptar a ele. Já não é mais a Vanessa, que ia sozinha pros lugares. Agora, eu tenho que ir com ele e pensando nele, e eu ainda não sei sair, porque a gente começou a sair agora, e eu ainda me sinto toda troncha, sabe? Meio desconfortável. Mas não por ele, mas pela situação, por todo mundo que tá em volta. Ainda me sinto bem desconfortável.

Sua grande exigência e expectativa de seu papel indica certa insegurança de ir testando o que fazer. Há uma ideia de ter que saber antes da experiência e de que esta tenha uma qualidade beirando os $100 \%$ :

É de ser uma coisa mais natural, de saber tirar de letra as situações. Eu ainda não sei fazer isso. A gente ainda saiu muito pouco. O [nome do marido] fala assim, às vezes, por exemplo, "ai, precisa comprar margarina". Eu falo pra ele "precisa comprar margarina". Ele: "por que você não pega o carrinho e vai com ele no mercado? É bom, que você sai de casa, respira um outro ar, e tudo... Eu falo "ó, uma, que o mercado deve tá cheio, ele vai ficar em contato com muita gente". Ele fala "não, cê vai num horário que tá vazio". Eu falo "ah, mas eu ainda não sei sair com ele, é melhor não ir". [risos] Eu fico meio que me escondendo, sabe? Eu falo assim "é melhor não ir"...

Volta a falar sobre como foi sofrido o momento em que o marido voltou a trabalhar e o impacto que sentiu com a total responsabilidade de cuidar do filho grande parte do dia, sem auxilio de ninguém:

Nossa! No início, eu senti muito isso! Porque uma coisa é você ter alguém sempre com você, né? Principalmente o pai, que é alguém em que eu confio 
$100 \%$ para deixar com ele, e outra coisa é você estar totalmente sozinha, Porque a minha mãe mora a duas horas daqui, a minha sogra também mora a duas horas daqui, irmão... todo mundo. Então, não tem ninguém, nem se eu quiser... Às vezes eu falo "não tem ninguém, nem se eu quiser ir lá à tarde só pra conversar", entendeu? Não tem ninguém também pra ajudar. Então, no início, eu senti muito.

Nos caminhos das perdas que a maternidade comporta, a experiência de Vanessa remete às vezes a tentar bravamente resistir aos extravios, mas, outras vezes, a perceber que algumas perdas podem ser a outra face de ganhos genuínos:

É uma adaptação que eu vou ter que fazer comigo, e depois comigo e com ele. Então, é muita coisa [risos]... é muita coisa pra adaptar! Pra duas pessoinhas! É muita coisa! Eu falo assim "antes era eu. Eu e eu. Era o mundo de Vanessa. Agora, é o mundo de [nome do bebê], né? Porque eu... se eu vou num lugar, não dá pra ir por causa dele. Eu não vou, né? E o que eu tô te falando: eu nem sei sair com ele. Mas são adaptações que valem a pena. Quando eu vejo esse sorrisinho dele, vale a pena. Ele tá crescendo, tá ficando mais durinho, tá mais espertinho. Como eu te falei: tá tendo menos medo das coisas, tá reconhecendo, assim. A gente percebe que reconhece mais as pessoas. Então, por exemplo, as duas avós, que vêm mais aqui, então, ele tem mais contato...

Com a possibilidade de ir gradativamente redimensionando seu papel materno, sua mãe e sua sogra podem ter lugar na vida do neto e Vanessa pode até mesmo incluí-las em seu projeto para quando voltar a trabalhar: pode deixar a criança ora com o marido, ora com uma das avós.

Parece que a situação mais aguda foi mudando. Tentam-se novas acomodações a partir da percepção das perdas e da necessidade de uma reorganização da família e da expectativa de seu papel materno. O peso e a pressão de fazer o filho viver atenuaram-se ligeiramente, dando lugar a um melhor aproveitamento do contato com o bebê.

Em todos os encontros que tivemos, Vanessa parece sempre querer prolongar o tempo que passa comigo. Agora, quando digo que seria nosso último encontro, ela me diz que sentirá minha falta, pois acha muito bom quando eu vou lá. Me convida para "aparecer pra tomar café quando quiser" e diz ainda: "quem sabe não passamos com você qualquer dia..." 


\section{CARLA}

ENCONTRO GESTACIONAL

\section{Sobre os excessos e os riscos...}

Carla me conta que já tem um filho, que ela e o marido nunca pensaram em ter um só, que aproveitaram bastante o relacionamento com o filho mais velho e que, em virtude da idade dela, acharam que esse seria o melhor momento para ter o segundo. Ela parece dizer de sua motivação para ter mais um filho e da responsabilidade que acredita ter na vida adulta do mais velho, que não deve estar "sozinho", seja nos momentos prazerosos, seja nos mais difíceis.

Representa o marido como aquele que precipita certo movimento no sentido de aumentar a família. Ele também foi o catalisador da mudança do casal rumo à constituição da família; por ele, teriam cinco filhos.

Para Carla, a gravidez é uma experiência importante, mas também ameaçadora e implica riscos. Ela indica que a passagem para a maternidade é tumultuada: a gestação é arriscada, envolvendo vida e morte, e ela gostaria de ter ainda mais um filho, mas não quer ter que passar por mais uma gestação - pensa em adotar uma criança. Quando Ihe perguntei sobre a natureza dessa preocupação na gestação, ela me explica que, na anterior, entrou prematuramente em trabalho de parto:

[...] fiquei muito assustada, porque tinha aquela coisa: fui internada, aquela
história nascer com um quilo e pouco, e aí pode ter problema disso e daquilo,
se sobreviver. Então, aí, eu... e, esta gestação está mais tranquila. Eu não
entrei em trabalho de parto e tal, mas eu já tô medicada, já tô... Então,
qualquer... começo a ter contração, eu já sei, eu já paro, já tomo algumas
providências, mas ainda me preocupa. Essa história me preocupa um pouco,
então, eu fico meio tensa. E o meu marido fica muito tenso, também...

Percebo que sofro um impacto com essa fala de Carla, talvez como representante desse risco que vive na gestação. Mesmo que ela me tenha dito que, durante essa gravidez, estava mais tranquila do ponto de vista físico, sua vivência psíquica não parecia estar. E ela continua contando como a preocupação com o risco não dá tréguas: "[...] não dá pra relaxar. Então, a gente tá meio... eu fico meio tensa, e ele também fica. Eu acho que ele fica pior. Eu acho". 
Carla parece sentir o marido como uma presença excessiva, quase intrusiva, talvez por seu desejo de ter cinco filhos e sua preocupação com a gestação. Ele não queria que ela trabalhasse depois do quarto mês e se preocupa também com as brincadeiras do filho mais velho dela, para não machucá-la.

A participante parece significar a experiência da maternidade a partir de dois vértices: o lado que "dá trabalho" e o que dá prazer: "[...] a gente sabe que dá trabalho, sabe que sacrifica uma parte da vida, mas, por outro lado, é um momento prazeroso".

Imagina que seu bebê será tranquilo, apesar de ser bastante agitado em seu ventre. Conta que, antes dos seis meses, não conseguia "ver" o bebê, diferentemente do que aconteceu com seu filho mais velho, com quem ela se lembra de ter sonhado desde o começo da gestação, e ele era muito diferente fisicamente, mas tinha um "jeito" parecido com o sonho. Penso que talvez evite sonhar com ele por medo de ter uma perda precoce: "[...] e é muito estranho, porque, toda vez que eu sonho, parece muito real".

A respeito de como imagina seu filho e a si mesma como mãe dessa segunda criança, convoca a experiência anterior, de quando se tornou mãe. No entanto, diz que só depois de conseguir "ver" o bebê consegue imaginá-lo.

[...] só que é estranho, porque, quando é bebê, a minha referência é muito o que eu vivi com o [nome do filho mais velho]... da história de amamentar, de trocar, de cuidar, de ficar ali, de ficar em casa, de ficar aquela coisa tranquila, aquela coisa gostosa, dar voltinha pra pegar sol. Então, eu imagino uma coisa muito parecida [...].

Parece sinalizar que a gestação é vivida, de modo geral, como ameaçadora, mas que o puerpério representa um "debruçar-se" sobre o bebê, e a experiência da maternidade pode ser vivida serenamente e com satisfação. Por certo ângulo, a gravidez pode ser simbolizada como perda, no entanto, a maternidade e o contato com o bebê são um ganho. Ela parece enfatizar a necessidade de se resguardar no momento em que seu filho nasce:

[...] acho que eu vou ter o mesmo comportamento: eu não gosto de sair, eu gosto de ficar em casa. Acho que não tem que ficar expondo a criança, e, quando eu vou amamentar, eu não gosto de amamentar no meio de um monte de gente. Não gosto. Muitas pessoas que estranham [...]. E eu não 
gosto, eu ia pro quarto, fechava a porta, e me incomodava demais as pessoas entrando, porque é um momento de tranquilidade, que você está aprendendo... e as pessoas lidam como se... uma coisa que me irrita muito. Isso foi uma coisa me incomodou demais.

A amamentação parece ter sido um foco de aborrecimento para ela, pois, apesar de seu filho mais velho não ter chorado de fome - ele é descrito como um bebê que demandava muito pouco -, ela percebeu que só saíam de seu seio "dois fiozinhos" de leite, explicando por que o bebê não ganhava muito peso. Associa a diminuição do leite a uma estressante experiência por que passou perto do nascimento do primeiro filho: a pessoa que alugava seu apartamento - onde iriam morar - não saiu na época combinada, e esse tempo se arrastou muito, causando muitos infortúnios.

Carla parece sentir como brutal a pressão de ter que fazer viver o bebê, e encontrar na exclusividade da amamentação um representante emblemático - a mamadeira pode servir como um terceiro elemento, um anteparo para a forte angústia de ter que garantir a sobrevivência do filho. Conta que sentiu certo "alívio" quando introduziu a mamadeira para alimentar o bebê.

Penso no "excesso" talvez ainda maior que pode representar o imperativo social de ter que amamentar, às vezes a qualquer custo, destacando-se os ganhos para o bebê e para a mãe, sem levar em conta as perdas dela própria - e, consequentemente, do bebê e da relação -, tomando a impossível dissociação do estado materno e do bem-estar do neonato.

No sexto mês de gestação, Carla começou a ter contrações e está medicada. Vem diminuindo gradativamente seu ritmo de trabalho, sentindo seu corpo extremamente sensível a alguns estímulos. Parece dizer da relação intrínseca entre seu corpo e seus estados emocionais.

Sobre seu momento atual e suas preocupações, diz que ficará mais tranquila quando conseguir ter arrumados o quarto do filho mais velho e do bebê, a mala da maternidade e as roupas nos devidos lugares, pois estão no meio de uma grande reforma em casa, e nada está no lugar. Fala ainda sobre sua preocupação com o trabalho, onde também precisa deixar algumas coisas em ordem para se afastar. 
Sua fala anuncia a verdadeira revolução precipitada pela chegada de mais um membro da família: nada fica no lugar, e a abertura necessária para que o outro venha é simbolizada por uma imensa reforma na casa - "reforma da parte interna e externa".

Finalmente, sobre o vínculo com sua família de origem, diz que sua relação com seus pais mudou muito. Quando eles se separaram, ela tinha 18 anos. $\mathrm{Na}$ época, aproximou-se da mãe e se afastou do pai, mas conta ter sentido um grande alívio, pois, desde pequena, só se lembra de seus desentendimentos, e não compreendia por que não se separavam.

Se dão superbem hoje, tal, mas foi um alivio. Foi, pra mim, a melhor coisa. Tem aquela coisa meio traumática quando é mesmo o rompimento, mas você passa a ter uma harmonia, uma paz em casa que eu não sabia nem o que que era, por causa desses conflitos.

Penso que essa fala de Carla pode indicar que as perdas podem vir a ser significadas posteriormente como ganhos, e que já havia perda num casamento que ela sentia como conflituoso. Agora, sente-se "afetivamente" mais próxima do pai e menos da mãe. Depois que se tornou mãe, percebeu que não pôde contar com a função "agregadora" de sua própria mãe, pois, para ela, a mãe "desconstruía muito a imagem do pai". Sente que seu pai é muito sincero, qualidade que ela valoriza, e conta com ele, caso precise de alguma ajuda com o filho mais velho.

\section{PRIMEIRO ENCONTRO APÓS O PARTO}

\section{Sobre o alívio e as incertezas...}

Contou que o parto foi tranquilo, mas antes foi "uma loucura", pois sua casa estava em reforma e ela tinha trabalho para entregar. Foi muito conturbado.

No parto anterior, precisou ser reanimada, pois sua pressão caiu muito, e teve muita náusea, acreditando que fosse vomitar, fato que a impediu de "aproveitar o momento". No segundo parto, passou bem, mas depois teve muita dor e muita náusea e vomitou, mesmo com medicamentos, na anestesia. Assim, apesar de sua 
fala, o momento do parto não foi tão tranquilo, embora, em comparação com a experiência anterior, essa tenha sido vivida de forma muito melhor.

Em função da anestesia, algumas parturientes sentem náuseas e vômitos durante e/ou após o parto, e, ao mesmo tempo, penso que o momento do parto parece ter sido vivido como muito ameaçador e talvez desagregador.

Penso também no fato de o bebê não estar no início da entrevista, tendo ficado com a avó em outro cômodo da casa, pois estava dormindo. Só depois de algum tempo, ao acordar, ele foi incluído no encontro comigo. Sinto que ela precisou antes me ver sozinha para então incluir a criança, autorizando-me a presenciar a amamentação.

Observo que ela tenta diminuir o impacto que pode ser o nascimento de um irmão para seu filho mais velho. No dia anterior ao parto, Carla ainda tentou manter sua rotina levando-o à escola e a suas atividades regulares, mesmo que isso lhe tomasse mais tempo e desse mais trabalho no momento pré-parto.

Conta que o marido estava nervoso, pois assistiu ao parto todo. Não o orientaram a assistir apenas o nascimento do bebê. Quando ela olhava para o marido, ele estava tenso e preocupado: "ele passa mal só de doar sangue; imagina assistir ao parto todo".

Carla parece ter ficado surpresa com o fato de o bebê ter nascido esfomeado; não sabe nada sobre essa questão. Ela tinha bastante leite e disse que estava tranquila; via uma diferença com o filho mais velho, pois não tinha muito leite quando ele nasceu.

Quando o bebê tem cólica, fica "desesperado" para mamar. Carla associa a cólica ao fato de o filho mamar muito e fazer muito cocô. Parece ela que vive tudo muito intensamente, e diferente do que estava acostumada com o filho mais velho: "é exatamente o oposto".

Os dois filhos são muito parecidos fisicamente, mas ela percebe diferenças significativas entre eles. É o bebê que estabelece os horários das mamadas, pois tem muita fome. Com o outro, era tudo programado; com esse, sai do esperado. Ela parece dizer que não tem controle nenhum, insinuando um certo excesso. 
Empenha-se em reduzir o impacto do nascimento do bebê no filho mais velho, mas parece dizer que é difícil atenuar esse impacto nela e no marido.

Também se ressente da mudança do marido: no nascimento do primeiro filho, ele estava muito mais presente e a apoiava. Diz que ele "enlouqueceu": "O bebê, eu sei que não trocaram na maternidade, mas o pai, eu acho que trocaram, porque ele está muito diferente! Porque ele é um paizão, muito, muito, muito".

Sente que ele perde um momento precioso do filho, e ela parece sentir-se privada de sua presença verdadeira, ficando magoada. Carla faz esforços consideráveis para entender esse momento especifico também para seu marido. Acredita que ele esteja sobrecarregado, mas às vezes sente que fica muito difícil.

O momento pós-parto do filho mais velho foi mais tranquilo do que o desse, acarretando também uma carga excessiva para ela. Apesar de estar em licença no trabalho, há certa demanda à qual ela tende a responder. Está dividida: não consegue desinvestir completamente do trabalho com a vinda do bebê.

Parece dizer que conta com a ajuda da mãe, mas não fala dela como alguém que a apoia e a sustenta.

O filho mais velho está encantando com o bebê; Carla diz que ele está "apaixonado", que não aparenta ter ciúme e que seu comportamento na escola não mudou.

Ela parece sofrer um forte impacto com a diferença do nascimento do primeiro e do segundo filho, sobretudo em relação à presença de seu marido e a questões do trabalho. Repete que, na época do nascimento do primeiro, estava muito tranquila no trabalho.

O suporte do marido na transição para a maternidade parece ter sido fundamental, mas a passagem da primiparidade para a multiparidade teve efeitos diferentes da vez anterior. Isso me leva a pensar que o encontro com o novo bebê importa algum excesso, mesmo que a transição para a maternidade já se tenha feito antes, na vinda do primeiro filho. 
Carla sente uma maior sensibilidade emocional desde a gestação. Diz que só continuou e que tem mais vontade de chorar; parece que algumas questões tomam uma proporção maior. Conta que, uma vez, o marido chegou do trabalho e, ao invés de ir ver o bebê, foi ver o trabalho que o pintor estava fazendo na casa. Diz que ficou muito brava com ele, e ele não entendeu. Conta esse episódio emocionada, com lágrimas nos olhos.

Algo interessante se apresentou a respeito da amamentação. $\mathrm{O}$ incômodo de amamentar em público não apareceu no encontro comigo: ela pôde partilhar o momento de intimidade que a amamentação representa para ela. Disse que o peito estava um pouco machucado, mas que a dor era suportável.

Fala dos dois lados da amamentação: gosta de amamentar, mas sente-se presa. Talvez essa questão aponte a total dependência do bebê em relação a ela. $O$ que parece se apresentar é a necessidade imperiosa de fazer viver o bebê, e só ela tem esse poder, com a amamentação exclusiva. Indica uma grande responsabilidade. A amamentação exclusiva parece ser um dos representantes da dependência absoluta do bebê em relação à mãe, da responsabilidade de fazê-lo viver. Para algumas mães, isso pode ser muito opressivo; brutal, até. Sua falta pode fazer o bebê não viver...

A primeira vez em que viu o bebê, o que primeiro sentiu foi alívio, pois ele estava bem. O nascimento, para a mãe e para o filho, envolve uma profunda transição, operada em meio a certos riscos ou incertezas. Aí, o desamparo aparece sem disfarces. A ruptura que representa o parto - tanto para a mãe, quanto para o bebê e também para o pai - indica uma separação concreta do corpo materno, com reverberações importantes para todos os envolvidos. Vida e morte parecem representadas de maneira crua no momento do nascimento de um filho, e as angústias decorrentes dessa separação. 


\section{SEGUNDO ENCONTRO APÓS O PARTO}

\section{Sobre os desequilíbrios e seus ecos...}

Sofro grande impacto ao ser recebida por Carla, junto com seu bebê, de máscara no rosto, na porta de sua casa. Penso na possibilidade de ele estar doente, mas ela explica que está resfriada e tem medo de contaminá-lo.

O dizer de Carla indica o caminho das perdas na experiência de ter um filho: o quanto "deteriora" o fato de não conseguir dormir direito e como a preocupa o incômodo do bebê; diz que ele "mama, chora e não dorme".

Observa e vai tentando decodificar os sinais que seu filho the transmite, e assim o vai conhecendo. Apesar de às vezes ser difícil compreender o motivo do desarranjo, não tenta evitar a angústia - fica em dúvida e chateada. Percebe as diferenças e recorre à experiência com o filho mais velho para entender a situação.

Percebo que o desequilíbrio se intensificou, ilustrado pelo desespero que ela sente quando o bebê não para de chorar; diz que, algumas vezes, chorou junto com ele. Ao mesmo tempo em que conta estar mais tranquila, diz que, quando começa o "choro desesperado" do bebê, ela fica "assustada e impotente". Expressa o quão árduo é este momento, mostrando estar de certa forma aterrorizada. Acha esse período muito difícil; gostaria de poder transpô-lo: "Eu falo 'acho que eu teria uns cinco filhos, se não fosse essa fase' [risos]... Apesar que de eu acho que depois é pior".

O impacto sentido na família é ilustrado também pelo filho mais velho. Agora, além de se mostrar com ciúme, revela sentir-se sobrecarregado. Tem que administrar o fato de ter um irmão, reverberando na necessidade de ter que dividir sua mãe e ainda ser mais independente.

Ela conta uma fala emblemática do menino: "ele falou assim 'joga [o bebê] lá! Aí, eu falei 'jogar, não, a mamãe vai colocar ele lá. Cê quer que eu coloque ele lá?' 'Não, eu quero que você jogue'. Ele nunca tinha falado assim, 'eu quero que você jogue ele lá' [...]". 
Carla se mostra sensibilizada com toda essa situação familiar, dizendo que chegou a chorar na frente do filho mais velho: "aí, ontem foi a pior que eu ouvi dele [...] Eu falo pra ele assim: 'vai arrumar seu quarto, vai não sei o quê'. 'Você fica aí sentada, relaxada' - Ele tá usando esse termo - "fica relaxada com o [nome do bebê], e eu fico fazendo tudo!' [risos].

Choros e risos expressam o quanto o nascimento do bebê desarticulou certo equilíbrio da família: a desarmonia é ilustrada pelo ciúme do filho mais velho, pelo fato de o bebê não mamar direito, ter dificuldade para arrotar, não dormir direito e chorar muito e por ela estar resfriada.

Apesar das dificuldades, percebo que Carla tenta ver os vários lados da situação, incluindo que o choro do bebê pode ser muito "irritante" e que o mais velho também pode se exasperar com ele, como ela.

É interessante perceber que, ao mesmo tempo em que conta como tem sido penoso esse momento, Carla consegue indicar algo precioso do ponto de vista do desenvolvimento do bebê e de sua relação com ele: percebe que o "olhar está mais vivo": "quando eles nascem, me dá uma sensação de olhar de velhinho... opaco, dá uma impressão de velhinho... eu digo que eles ainda tão do lado de lá [risos]. Aí, depois, vai ficando mais vivo, né?"

Em várias situações, sua fala parece indicar uma carência de apoio. Diz que sua mãe a ajudou muito, mas que ela tem "prazo de validade". Em contrapartida, percebe que a presença efetiva do marido é fundamental e que, com sua falta, tende a se desestruturar.

Nesse período de sobrecarga de trabalho do marido, ela se ressente de sua ausência, mas diz que percebe melhoras em sua participação com o bebê. Conta que, quando ele avisou que viajaria a trabalho no dia seguinte, aflorou em Carla uma solidão brutal, acompanhada de uma sensação maior de desamparo: "aí, te dá aquela angústia, assim, putz! Te dá meio uma angústia de que você vai ficar sozinha". Mas diz que conversaram, e ele conseguiu mudar a data da viagem para que ela pudesse se organizar e pedir ajuda para não ficar sozinha com as crianças. 
O fato de o casal conseguir conversar para "corrigir a rota" é fundamental. No caso de Carla, em função do diálogo com o marido, ela acaba se sentindo amparada novamente.

As falas de Carla simbolizam o caminho das perdas que se acumulam desde o nascimento do filho: ela parece fazer uma espécie de inventário dos prejuízos e danos e tende a acreditar que alguns são temporários, e outros, mais árduos.

O amparo do marido e o sono são considerados fundamentais, mas outra perda importante é o convívio mais próximo com o filho mais velho. Carla comenta também que sente falta de "sair de casa tranquila, porque sai como uma doida" apesar de acreditar ser um período transitório.

Percebe que o leite diminui com a falta de sono, e, quando discute com o marido, toma os medicamentos indicados para ajudar na produção de leite. Além disso, para a noite, introduziu uma mamadeira de leite em fórmula, e tudo isso parece ter sido vivido como alento, por ter aliviado seu extremo cansaço.

\section{TERCEIRO ENCONTRO APÓS O PARTO}

\section{Sobre o cuidado do olhar...}

Percebo que, gradativamente, nossos encontros vão ficando mais íntimos, e ela parece preservar cada vez mais a hora que passamos juntas.

Seu filho não é mais um estranho: ela o conhece cada vez mais e acredita nesse precioso saber. Conseguiu provocar certa mudança de postura do pediatra, que passou a ouvi-la mais. Fez com que ele respeitasse sua opinião sobre o choro intenso do bebê: ela acreditava que não era causado por cólica, como o médico havia dito. Ele então investigou melhor e diagnosticou um retardo do esvaziamento gástrico, medicando a criança, o que levou a uma melhora do quadro. 
Carla aponta a importância da atenção às sutilezas e como a intimidade e o ritmo fazem diferença no encontro com o outro. Em suma, como é fundamental conectar-se com as reais necessidades do bebê nesses primeiros tempos.

Uma antiga fala da médica de seu filho mais velho a ajudou entender como segurar um bebê que acaba de mamar e como a sutileza pode fazer muita diferença: "bebê é como um copo cheio: tem que ter muito cuidado".

Ressalta a importância de o pediatra estar apto a acolher, e não apenas fazer tecnicamente seu trabalho. Amparar pode ser fazer algo sutil: ouvir os pais com atenção ou dar indicações simples mas eficientes, que podem atenuar um sofrimento - como na analogia entre o bebê e um copo cheio.

Indica ainda a necessidade de, além de ter conhecimentos técnicos, o médico ser alguém que possa amparar a família. Carla estava decidida a procurar um profissional que tivesse esse "outro lado", pois esse havia errado ao não escutá-la na questão do sintoma, uma vez que a consulta era rápida e ele parecia não prestar atenção ao que ela Ihe dizia.

Diz que seu leite diminuiu a ponto de ser insuficiente e parece surpresa com o fato de esse bebê demandar mais dela do que o primeiro; ela o vê como uma criança mais intensa. Tinha a expectativa de que os dois seriam parecidos, o que não se confirmou, exigindo de Carla outro aprendizado. Apesar de não ser primípara, ela percebe que cada filho solicita os pais de uma forma diferente.

A participante indica que a amamentar é um ponto de conflito e parece simbolizar uma espécie de fantasia de esvaziamento:

$E$ eu acho que amamentar te puxa muita energia, pelo menos pra mim. Depois que eu parei, eu engordei três quilos! Assim, eu percebo que é uma coisa que te... eu acho que algumas mais, e outras menos. Pra mim, é bem puxado, assim. O organismo, mesmo, te debilita mais. Então, eu acho que isso, assim... não é que... acabou, de certa forma, não melhorando - não dá pra dizer isso-, mas foi o que eu consegui fazer. Eu fui até onde deu, assim. Nossa, eu fui até o limite mesmo. Depois disso... eu não consegui... 
Suponho que, para Carla, a mamadeira passa a ser usada como um terceiro elemento: serve para intermediar uma relação na qual se sente muito requisitada e, com receio de a "fome do bebê não ter limite", não ser suficiente para ele. A introdução da mamadeira sinaliza certo alívio, e a relação pode seguir um rumo mais tranquilo. Ela também não precisa ser imprescindível - pode ser, de certa forma, substituída, aliviando sua angústia.

Também com o filho mais velho parece haver agora um movimento mais harmônico: ela consegue encontrar um pouco mais de espaço para ficar com ele:

Eu to conseguindo dar mais apoio, isso também me deixa mais tranquila, porque, antes, eu tinha uma saudade. Ele tava ali do lado, mas eu tinha saudade, sabe aquela saudade? Uma saudade absurda de ficar com ele, assim, e não conseguia, né? A palavra era mesmo saudade, um sentimento tão esquisito! Porque saudade se imagina uma pessoa longe, né? Não é? E ele do lado...

Diz que voltar a ter algumas coisas no lugar a conforta. O filho agora pode pedir sua presença normalmente - ela diz que ele não encontrava espaço nem para pedir, o que a deixava muito chateada. No entanto, em relação ao trabalho, parece que voltou a ter que se dedicar minimamente, mesmo de longe.

Entretanto, parece dizer que agora, em sua trilha, não há só perdas: pode também contabilizar os ganhos. Percebo que, além de sentir prazer no encontro com seu bebê, estabeleceu com ele uma comunicação pelo olhar e pode compreendê-lo:

Então, o olhar dele, eu falo que é o que mais me... o que mais me chama atenção nele são os olhos, porque ele... principalmente quando ele não tá bem, ele olha no meu olho, sabe uma coisa assim, de meio pedir socorro? É uma coisa tão estranha, Cris! Tão assim... E isso já faz um tempo. É muito forte, sabe? Parece que ele procura o meu olhar e faz uma carinha de pedindo socorro pra mim, sabe? [risos] Então, o olhar...

Penso que, analogamente, algumas vezes seu olhar também foi um pedido de socorro...

Carla fez um caminho de alguns desencontros com o bebê, com o marido, com o filho mais velho, mas encontrou uma possibilidade de pensar os desencontros e os conflitos e considerar seu lado e do outro, procurando soluções melhores. 
Terminada a entrevista, ela pergunta como vai minha tese. Respondo que estou trabalhando bastante e que esta seria nossa última entrevista. Ela diz que isso é bom e ruim. Bom para mim, para eu terminar o trabalho, mas ruim porque não íamos mais nos ver.

$\mathrm{Na}$ despedida, eu lhe agradeci, e ela também se mostrou grata e disse que tinha sido um prazer muito grande me conhecer. Reiterou-se minha impressão agora confirmada por sua fala - de que Carla esperava o encontro comigo, foi gradativamente se aproximando de mim e aproveitou nossas conversas para pensar sobre as questões que a impactaram após o nascimento de seu segundo filho. 


\section{QUADROS-RESUMO}

\section{ENTREVISTA GESTACIONAL}

Como se

apresenta ao

contato

\section{$O$ que diz \\ sobre a}

gravidez

Pré-gravidez

Antecipação

do bebê e do

papel materno

Rede de apoio

e vínculo

Durante a

entrevista

\section{Isabela}

Acessível e interessada. Aberta ao contato.

Surpresa de estar grávida e depois de saber que eram gêmeos e perda de um dos fetos e sua elaboração.

Adiamento do desejo de engravidar. Elaboração de

$$
\text { perdas. }
$$

Quanto mais cresce o bebê no ventre, maior o vinculo. Desinveste um pouco da carreira. Arruma o quartinho.

Marido: presente, apoia. Mãe: apoia, conta com ela.

\section{Pensa junto a} pesquisadora sobre os medos e expectativas frente ao bebê, a

maternidade e suas transformações. Angústia sofre diminuição. Paciente.

\section{Érika}

Desmarca encontros.

Não foi "nenhuma loucura", mas, parece que teve um sim uma

loucura, bloco único: primeiro e segundo filho.

Pragmática: seu ideal a "amiga do relógio"

Fala da primeira gravidez, quando tornouse mãe-bloco único.

Perdas -amortecendo o impacto. Onde esta o bebê? Dificuldade de retirar-se. Reforma atrasada.

Babá e empregada. Ela tem que cuidar da mãe.

Pontos sensíveis escorrem por suas falas, parece não se apropriar deles, recorre ao "bom

humor" potência e aspectos sensíveis, dois lados da mesma moeda.

\section{Gabriela}

Um pouco tensa. Existe um jeito certo.

Planejada mas com susto. Gravidez

precipitada no tempo.

Gravidez bem aceita. Por quem?

Marcação na agenda. Foi fácil engravidar. Perdas e transformações.

Chateada com muito sono, chorava

sensibilidade - "eu não aguento isso, muito devagar". Bebê do mundo.

Rede de apoio parece frágil.

Certa tensão no início da entrevista,

impressão de certa solidão.

\section{Carla}

Início um pouco distante.

Gravidez importante mas arriscada, não dá para relaxar, envolve riscos.

Casal nunca pensou em ter um único filho, irmão para seu filho quando ficar mais velho. Filho com idade boa e a idade dela.

Após os seis meses,

quando tem menos risco, consegue visualizar o filho. Necessidade de

resguardar-se, alivio

quando o bebê não depende $100 \%$ dela.

Dois lados da maternidade:dá trabalho, mas dá prazer.

Reforma grande da casa, casa "de pernas pro ar".

\section{Vanessa}

Animada a colaborar com o estudo.

Eufórica.

Não dava para acreditar que estava grávida. Surpresa $X$ insegurança. Bebê da gestação: bebê 100\%.

Tumultuada, perdas: entando engravidar

$$
\text { há dois anos. }
$$

Bebê igual a ela, bebê amiliar, não é um estranho.

Conta completamente com o marido e só ele. Casal sente-se invadido pela família, tem que ficar longe.

Fala bastante e de forma muito eloquente e exaltada. 


\section{PRIMEIRO ENCONTRO APOS O PARTO}

Data da entrevista

\section{sabela}

$$
\text { parto. }
$$

Cesárea, sem coragem para parto normal, receio

da episiotomia.

Parto

Experiência mágica.

Marido junto dividindo a emoção. Segura com a médica.

Impacto com a dor não esperava -

engurgitamento

Sobre as dores e os amores

Construção do vínculo com o bebê real

\section{Construção da \\ parentalidade/}

maternidade

Impactos do nascimento do bebê

odia esperar pela dor do parto.Emocão indescritível choro do filho ao nascer. Muda o corpo, muda toda a vida.

Demanda amparo, olha para o olho dele assustado e o ampara.

Estranhamento inicial- não ventre, percepção

desamparo. possibilidade de ir conhecendo e tornando-se sua mãe, ferecer amparo. Uma descoberta a cada dia

Responsabilidade grande de chegar em casa com o bebê, cuidar de sua sobrevivência. No marido,

\section{Érika}

Uma semana após o parto.

Cesárea. Horror da anestesia. Marido não assistiu o parto: muito sangue e não entende nada, não sabe se está bom ou ruim. Mãe: fundamental segurar a mão de sua mãe.

Dor no corpo e dor na alma: Peito machucado, dor da cesárea, horror de não sentir as acreditar filho saiu de seu nela, na mãe e "administrar a família do marido".
pernas.Outras dores: ciúme do filho mais velho, pais ficando mais velhos.

Dificuldade de desinvestir de outras esferas para investir no bebê.

Dificuldade preocupação materna primária.

Tentativa de amortecer os impactos da vinda do bebê para todos

principalmente para o filho mais velho tem que ter o dia a dia normal.

Desequilíbrio aparece com o ciúme do filho mais velho.Triste com essa situação, sente-se traída, ressentida.Tenta amenizar o impacto sentido.
Gabriela
Vinte e seis dias após o parto.

Cesárea. Susto de ter chegado a hora, não estar preparada, parece ter sido pega desprevenida. Parto : "Emoção... não tem como descrever..."

Sobre a dor: involucão do útero, dor infernal. Dor de ser tão necessária para fazer o filho viver. A dor dificulta o amor. Olhar do filho nas mamadasprazeroso.

Assustada com o impacto do bebê demandar tanto dela no início da vida.

Encontro com as demandas do filho parece ter sido assustador $e$ desesperador. Ficar sozinha com o filho. Desamparo materno.

Muito sofrimento, seu filho traz a necessidade de um total

descentramento psíquico que ela sente dificuldade de fazer.

\section{Carla}

Uma semana após o

$$
\text { parto. }
$$

Cesárea. Depois do

parto, muita dor, enjoo e vômito. Alívio ao saber que o filho estava bem.

Uma ameaça.Marido

impressionado pois assistiu a todos os detalhes.

Sobre as dores: físicas superadas mais

facilmente do a alma.

Sobre os amores: o bebê demanda de forma

diversa do mais velho-

apaixona-se por ele. Laço com mais velho- bastante intenso.

Percebe o quanto os filhos são diferentes, como eles demandam dela um posicionamento diferente.

dois filho-carga de trabalho diferente.

Administrar a

complexidade das

relações deverá haver uma reorganização para poder acolher o novo

membro, no primeiro filho era mais tranquilo.

Diminuir o impacto para seu filho mais velho, manter rotina, incluindo sua presença. Marido mais ausente, cuida do entorno, ela ressente sua falta.

\section{Vaness}

Uma semana após o

parto.

Cesárea. Muito insegura. Emoção X Preocupação. "deixa mais um pouquinho aqui dentro". Marido

ajudou no parto. Parto do filho - parto da mãe.

Sobre as dores: físicas não reclama- dor de ter perdido bebê do ventre (idealizado). Chorosa. Amor ao bebê idealizado, cede lugar às dores do bebê real.Aprender sobre o filho, e sobre ela mesma como mãe.

Desamparo materno, filho nasceu, o bebê do ventre não é o mesmo de agora.

Surpresa de lidar com um desconhecido, apesar muito conhecido no ventre. A separação faz sofrer. Felicidade X Insegurança: Será que vai dar conta? Será que vai fazer sempre o melhor para filho?

Pai sobrecarregado: demanda de pai, e de "acudir" a mulher. Casal sente maior entrosamento, relação melhor depois da gravidez. 
Amamentação

Sensibilidade/tristeza

Suporte/apoio

Lugar do pai

O bebê
Isabela

Inicio muita dor-pensou se conseguiria amamenta

o filho. Agora-momento

mágico. Namorando o

filho enquanto amamenta.

Chora: ao contar do

nascimento-mais emotiva na primeira semana. Ao brigar com marido,dor no peito.Está sendo mais difícil do que imaginava. queria chegar em casa e ficar sozinha.

Mãe ajuda e respeita, prefere afastar-se

momentaneamente a

intrometer-se. Cuidado e amparo materno: única pessoa preocupada com ela e bebê.

No parto dividiu a emoção.O marido"pirou", querer controlar tudo,

"leão de chácara",

"participativo até demais".

Bebê bonzinho, " o mais lindo da floresta"!

Colabora, espera um pouco, ela saber qual seio que era para oferecer.
Érika

De forma um pouco prejudicada. Anotando o horário das mamadas, por determinação da pediatra,

uma em uma hora.

Preocupação e percepção pais mais velhos. Parece com receio parecer triste. preocupação: alteração do comportamento- filho mais velho.

Sente que precisa cuidar dos pais.Marido ajuda com o filho mais velho. Sente-se no lugar de ter que dar suporte.

Coopera principalmente nos cuidados com o filho mais velho, com a menor põe para arrotar. Diz que "parece até outra pessoa" pelo fato de estar ajudando mais.

Bebê bonzinho, mama direitinho, dorme, tomou banho sem chorar.

Diferença física entre os dois filhos. discurso a respeito do bebê não aparece muito.
Gabriela

mamentação diz que está bem e fala que o

filho agora olha, toca que é gostoso.

A sensibilidade traduzida talvez em ansiedade.

Parece ressentir da falta de apoio maior. Parece estar muito sozinha na

tarefa de cuidar.

Marido junto no parto acalmando-a. Fica junto à noite quando amamenta, e depois põe para arrotar

No fim de semana dá

banho. Cuida da

alimentação dela.

Bebê chora das seis, sete da manhã às quatro da tarde, nos primeiros dias estava muito tranquilo.
Carla

Diferenca entre filhos. Bebê faminto,ele stabelece os horários.

Gosta mas presa na

amamentação exclusivatotal dependência bebê: opressora.

Sensível desde gestação, vontade de chorar, algumas questões - proporção maior. Conta emocionada episódio com marido tocou muito.

Ajuda da mãe-pontua Uma pessoa ajuda casa, mas parece fica ressentida falta de

suporte - ma rido, como tinha com primeiro filho.

Ressente-presença verdadeira do marido, muito preocupado com trabalho e reforma da casa. "Pai trocado na maternidade" muito diferente do primeiro filhoEle a apoiava muito "enlouquece".

Bebê "comilão" "faminto" demanda mais dela, mas está gostando de ser sua mãe.Têm um pouco de cólicas.
Vanessa

Peitos preparados sem dor- bebê engasga muito e quase asfixiou- preocupase muito - diz excesso de leite e força da sucção do

filho. Amamentação angustiada

Chora bebê e mãe Engasgos - risco de 0 bebê sufocar - chorou muito marido conta sobre choros. Preocupação: integridade do bebê, e

qualquer mal-estar - medo de perdê-lo. Sensibilidade maior.

Marido - estritamente necessário, fazem tudo junto nos cuidados.Mãe não é sentida como a apoia, sente-se invadida.

Marido ajudou no parto (emocionado). Marido é imprescindível para ela, forte presença, sem ele muito insegura.

Bebê "genioso", com "vontade própria", faz escolhas, não gosta de um ambiente mais escuro, pede, reclama. 
SEGUNDO ENCONTRO APÓS O PARTO Isabela

Sobre dores amores do mesmo jeito. Conhece seu

Mobilidade
Percebe mudanças ela e no bebê/

Confiança na capacidade de ser mãe construção do papel materno
Dores: perder a liberdade Corrigir a rota. Decisão insana: um filho,vida transtornada transformada, constante

preocupaçăo, exige trabalho físico e menta.,Amores: paixão pelo bebê- descentralização do narcisismo/tranvasar azer viver seu filho. Roupas: encontrar novos lugares.

Questões móveis, não mais filho, vai criando pratica, e ele crescendo, sabendo qualquer coisa- não é um bichinho 100\%- desafoga a mãe, mais segura, confia na capacidade de ser mãe.

Deixando de ser estrangeira como mãe - transição.

Ajustando - tenta encontrar $100 \%$ - mãe falível, mãe real. Percebe as competências de seu filho. ternado-. Falta prazer na comunicar - não vai morrer por solução. Não dá para ser mãe

\section{Érika}

Dores: tentativa amortece impacto: filho com ciúme,

regrediu-desorganização na

família. Bebê doente,

internado. Caos:

desorganização, aparece dificuldade entrar em contato e processamento das

questões não vão bem alvez impedindo ganhos. Perde liberdade-

prisão.Preocupação: nova formas, principalmente quando voltar a trabalhar dois filhos.

Não relata alteraçõeschama atenção bebe

\section{Gabriela}

Dores:medo de perder o filho. Vida deixou de ser sua- bebê levou embora.Exaurida,

$$
\text { esvaziada }
$$

narcisicamente. Angustia: não pode levar vida de alta de liberdade de fazer o que quisesse.

Desespero: cabelos caindo. Um ganho:

aproximou-se de sua irmã. Novo lugar, vida anterior, não encontra muito prazer.

Parece perdurar desencontro. Viagem: desencontro atenuado. Conexão com seu filho prejudicada? Difícil acertar o tom. Certa sobre diferences entres ou seu papel materno penas na amamentação: com primeiro filho até dormia, com esse não, mas diz gostar muito de

amamentar. Segue a risca pela pediatra.

dificuldade de ver bebê, dependente de seus talvez sozinha? Bebê "batata quente"?Bebê ainda um pouco estranho não sabe se o choro é fome, mas normalmente antes, Ressente-se da

dificuldade de desinvesti

\section{Carla}

ão dormir direitodeteriora, falta de sair tranquila: preocupação fome, falta das atividades filho mais velho. Transitório mas sente alta. Amortecer impacto para odos. Angustia: sozinha, sem choro e incômodo intenso. Fase de bebê considera muito difícil, pressão fazer viver . Os mores: Olhar do bebê mais vivo! Bebê está grande! Apesar das dificuldades, os ganhos.

Questões alteradas- mas piorou o estado geral do bebê. Conhece mais ele dá sinaisela decodifica, tristeza:

cômodo e o sofrimento dele. Relação implicada:conectada estados e alterações.

cuidados Assustador $e$ amamenta.

ificuldade de entender: não tenta negar angústia,faz uso para compreender. Percebe sutis diferenças-

comportamento do filho, não mais estranho, utiliza experiência com filho mais velho na sua compreensão sem esquecer das diferenças entre eles. Apesar das o apoio do marido. Bebê

\section{Vanessa}

Dores: transtornos,turbilhão filho traz, reviravolta materna: alimentação, sono e higiene. Tensão sem tréguas, não dá para tira férias, não há intervalo sobre o desamparo. Leite diminuindo. Perdas vida pessoal e casal.

Desarmonias; chora o bebê, chora a mãe. Sobre os amores: concentrados no bebê e mãe idealizadosnecessário construção relação real.

Mobilidade preservada, no entanto parece que os dificuldades percebe os ganhos do filho. ranstornos continuaram po um lado, e transformaram-se por outro. As questoes puderam deslizar da primeira para a segunda entrevista pós-parto. Mãe excesso $x$ mãe escassa. 
Retroalimentação mãe-bebe. Praze

na relação

Rede de apoio

"Manhês"

\section{Isabela}

Bebê engorda e cresce indicativo tudo certoretroalimenta mãe. Dois lados da moeda - perdas e ganhos: não pode sair de casa - mamar, é uma experiência ruim e boa. Amamentação: momento de troca, olha, dá risada, muito gostoso.

Funciona, marido está aprendendo aos poucos a cuidar do bebê, mas olera isso dele. Apoio materno, alento e

amparo, ajudou a cuida do bebê, e cuidou do filho. Realimentou-se nesse contato, é possível amenizar a dor, o cansaço, sogra não ajuda, não confia o filho a ela.

Fala em "manhês", prazer nessa conversa, e quer dividir esse prazer comigo, me inclui na conversa com ele.

Érika

Retroalimentação prejudicada? filho cresce, ngorda e mama, mas não parece alvo-regozijo materno. Cuidados talvez desprovidos de prazer, drecono prejuízo na relação -

egrada- não descobre no contato mas pediatra diz.

Parece ter uma rede de apoio operacional, empregada e babá, mas parece não poder contar com uma rede de sustentação verdadeira somada à certa

dade de sentir que isso é necessário. Valoriza o bom humor, ques da vivencia de caos que sente em sua vida.

O filho dorme a entrevista inteira.

\section{Gabriela}

retroalimentação rejudicada? relação com o nâo parece fonte d pisicamente? enquanto o filho cresce e mais competente. Perdas dão o tom na relação, e certo sacrifício. penoso e

aterrorizante? Desamparo, dor atroz, bebê precisa crescer rápido.

Parece faltar suporte, seu marido e sua mãe parecem não conseguir cumprir essa funça, manifesta ser sua mãe é muito companheira. Rede de sustentação frágil.

Fala em "manhês" em algumas oportunidade com o filho.
Carla

Vanessa

Engordar, crescer e procurar o olhar: mãe retroalimentada. Mas choro desesperado do filho faz chorar junto com ele: sobre o desamparo sentido. Fica

assustada, impotente

desesperada. olhar: diferença do começo, compara ao olhar de um velinho sem vida e depois vivo.

Apoio do marido é fundamental, do contrário ela se desestrutura, ele melhorou em relação ao ebê, investe mais, mas está muito sobrecarregado no

trabalho. Solidão, tristeza, coisa tão ruim. Correção da rota, o casal conversa e tenta se

acertar, ela tenta considerar o lado do marido. Falta apoio. Sua mãe tem "prazo de validade", diz que sua mãe sempre foi muito dura com ela e com os irmãos, sempre fizeram tudo sozinhos. marido ajuda no banho do bebê.

Bebê dormindo, quando acorda incomodado tenta apaziguá-lo confortá-lo.
O bebê cresce e desenvolve-se "ficando durinho" ajuda sua mãe acreditar que apesar das iculdades, o bebe sobrevive.

No primeiro mês o pai estava de férias, ajudando com o bebê, no mesmo momento que o pai volta a trabalhar, o bebê muda seu padrão de sono, de mamadas, o choro fica mais intenso. O marido tenta "animar" a mulher. Sua mãe e sua sogra ajudam, em alguns momentos com a casa e a alimentação. Não parece aceitar substitutos maternos, apenas o pai do bebê pode ficar nessa função.

Fala em "manhês" com o filho, inclui a pesquisadora na conversa com ele. 
Sobre a entrevista

Cuida do encontro, não deixa entrevista seja interrompida, me convoca, quer saber que sente é nc mas acredita que sim.

Bebê está interagindo mais,fixa o olhar acompanha,

reconhece a mãe,

escuta a voz...

Contato com

Sobre os impactos da inda de um filho ou sobre as everberações do susto? balanceamento deles relação prazerosa

Érika

Entrevista atrasada um mês. Talvez conversa um pouco por "obrigação" cumprindo um certo papel.

Dente logo após o nascimento, por um período chorava das seis às dez da noite, mas diz que não dá trabalho

Tenta amortecer os impactos, seja da tristeza, do caos, das perdas, muito$$
\text { sobrecarregada. }
$$

Vanessa

Bebê doente, internado,

Entrevista muito atrasada, o bebê já fez quatro meses. Realizada em um espaço das prédio. demoraram para diagnosticar, o que deixou os pais muito angustiados. Bebê ainda mamadas chora até quarenta minutos seguidos, engasgava e depois refluxo.Chora de

$$
\text { ficar no carrinho. }
$$

Impactos sofridos, exaurida roubada? falta suporte? estranhamentos: pai tenta construir um jeito de ser. Impacto e desarmonia: casa.

\section{Gabriela}

Carla dependências comuns do chora muito, depois das

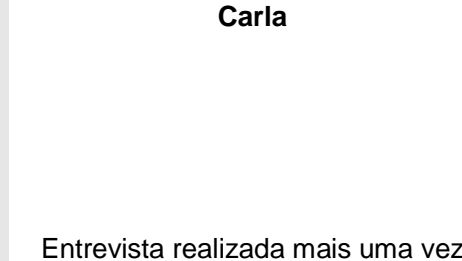

Entrevista realizada mais uma vez cada vez mais no contato.

Bebê cresce e engorda, mas não está bem, em dez dias o quadro passou de sutil para mais sério. agravou. Incômodo muito grande; mama chora não dorme e tem dificuldade para arrotar.

Marido trocado e voltando aos
Marido trocado e voltando aos não mama direito, chora,e não dorme direito, ela resfriada. Filho mais velho sobrecarregado- ela angustiada, sente falta dele. alteração no leite- falta de sono e preocupação.
Entrevista realizada na sala, pai participa em alguns momentos. clima:apresenta alteração: muito tenso quase desesperado- mais tranquilo, pensar?apaziguar? Fala para pediatra:sou psicóloga dela

Bebê quer ficar apenas no colo e mamando, chora muito, desconforto grande, dorme trinta minutos e acorda nos últimos dois dias.

\section{Difícil enfrentamento:} demandas bebê real, incessantes surpresas -novo diferente do idealizado. Pai dividido entre o choro da mulher e o choro do filho. Frustração:não conseguir amamentar como planejava. 


\section{TERCEIRO ENCONTRO APOS O PARTO}

Desenvolvimento do bebê retroalimenta a mãe- vínculo

\section{Sobre as perdas e} rupturas

Rotina do bebê, rotina da mãe ou sobre a instalação dos ritmos nos cuidados com o filho pais privilegiados. mudanças voltar a Isabela

Apaixona-se mais por ele bebê responde, bebê saudável, relação

Érika - 3 meses de atraso Não parece haver predomínio da

retroalimentação na

relação com o filho. Sentese sobrecarregada, filho mais velho operado, mãe doente e, complicações pulmonares do bebê, e o trabalho, não parece haver investimentos privilegiados no filho.

Vivenciar as

transições:ganhos, prazer nutrida pela presença do filho. Perdas temporárias suportáveis:ganho de prazer, perder para ganhar?Adia ruptura do desmame. Prevê dificuldades, novas trabalhar. Pode pensar, tentativa preparar 0 enfrentamento novas

fases. Não pensa em não voltar a trabalhar.

Rotina prazerosa, faz experimentações do que pode ser bom para o bebê. Não é automática.

Difícil contato com as perdas. Várias

preocupações mas talvez sempre amortecer o

mpacto. Sobrecarregada pelas intercorrências. Não podem ser pensadas?

Quer trégua, quer férias." Não dá tempo de ter depressão, não dá".

Talvez lide com a

angústia, tentando

organizar as atividades.

Não relata, parece ter sido atropelada pela mudança de ritmo, desde o primeiro filho e que aumenta com a chegada do segundo com questões familiares. A pediatra fala ela cumpre. Mecanicamente?

\section{Gabriela}

Narcisismo não tranvasa? Sente-se exaurida e talvez esvaziada? Percebe 0 desenvolvimento de seu filho, mas parece que ainda não está suficientemente competente. Precisa crescer depressa.

Voltar a comer normalmente, cansada de amamentar.

\section{Carla}

Comunicação pelo olhar reconhecimento das suas necessidades. Há prazer no encontro com seu filho, mas há

também surpresa pelas demandas novas que ele lhe traz. Sobre os

impactos e intensidades.

Parece encarar as Sobrecarregada pelas perdas? Não pode haver diferença entre perdas temporárias e definitivas. Quer voltar a sair, ter" vida de casal". Abrir mão: parece penoso, arrancar à força? Berçário e procurar trabalhar. Mudança no antigo plano de ter um filho logo após o outro. O filho real implica em muitos investimentos e perdas.

Rotina instalada: grude separação abrupta ?

necessidade de preencher espaços vazios, berçário, natação? dificuldades como algo ser transformado, investe

na possibilidade de

mudar algo que não esta caminhando bem. Tenta lado do outro.

Investimento grande no trabalho, aparece novamente. "Cabeça muito cheia".

Filho responde aos cuidados, a intimidade ao ritmo. As sutilezas são levadas em conta e fazem diferença no bem estar do bebê e na sua relação com ele. ir corrigindo a rota. Vê o
Vanessa

Comunicação pelo olhar, mas talvez um pouco persecutório. Entre a paixão e a raiva. Vínculo crescendo, mas filho tem que entender: não tem muito leite. Relação caminhando - talvez ainda muito tingida com as cores das projeções maternas.

Perda da onipotência narcísica, não poder amamentar como plano de mãe $100 \%$ ? Mãe mais

dealizada? Filho: traz os infortúnios da natureza humana. Não gostaria de ter deixado de

mamentar seu bebê de maneira exclusiva, mas não viu outra

possibilidade, ia "deixá-lo com fome"?

Tentativa organização da rotina: dificuldade de diferenciação entre ela e o bebê em alguns momentos. Questão da presença-ausência instalação dos ritmos. 
Filho não é mais um estranho

Casal

\section{Estado emocional da}

mãe

\section{Isabela}

Autoriza-se a cuidar, sabe melhor para ele. Surpresa positiva, imaginava filho exigiria muito mais dela. aprende a conhecer as sutilezas das expressões do bebê. sua importância para ele. Percebe

mudanças no crescimento e desenvolvimento.

Esforços para acerto do ritmo. Marido não queria perder, não queria abrir mão de suas atividades habituais. Conversaramcaminham juntos. Marido deixa de ser apenas filho de sua mãe, assume o lugar de pai de seu filho.

Mais tranquila, prazer, dificuldades com marido na adaptação às novas funções foram atenuadas conversadas, suporte eficiente da mãe e marido, ajuda com as questões domésticas. Continua em amamentação exclusiva, com ganho materno.
Érika - 3 meses de atraso

Discurso pouco empobrecido?"Fofinho, mas não vejo a hora de crescer". Filho bonzinho mas com questões pulmonares. Crescer para talvez para liberá-la? Bebê:sempre que oferece quer mamar, diferente do outro

Sobre o marido ele ajuda bastante com o filho mais velha, e acha que até virou outra pessoa.

Extremo cansaço continua em

amamentação exclusiva: mamadeira com leite materno depois que voltou trabalhar. Não houve diminuição do leite. Voltar a trabalhar, parece trazer certo alívio. Sobrecarga: dificuldades familiares

\section{Gabriela}

Não é um estranho, dificuldade de saber realmente passa com ele.Querer que seu filho cresça rapidamente? Dificuldade de ver sua importância para o filho, precisa escutar das outras pessoas que o filho não tira os olhos dela.

Eleito pelo filho para

\section{Carla}

Conhece seu filho acredita nesse saber, fez médico dar atenção ao sintoma . Vê diferença entre os filhos, Bebê mais intenso, mais risada, chora mais, come mais.

Pensam e conversam: melhor forma possível. Ajustes necessários, compreende o lado do outro,mas assume suas necessidades. Intenção de encontro, feito a parti de ajustes na relação.

Mais tranquila $e$ confiante desde a

Desespero, pânico. Diz não gostar de ficar em casa, fica desesperada. Quando para de chover sai rapidamente com o filho para andar de carrinho. Parece nunca estar onde deveria? Parece faltar apoio, sustentação fica muito sozinha com o filho e sobrecarregada. melhora dos sintomas do de seu sono,e ter deixado de amamentar exige muito dela, a debilitava.Com marido e

sentia muita falta de estar com ele.Trabalho surpreende-se com elas.

\section{Vanessa}

Construção paulatina com o bebê real. Filho parecido com a mãe, bravo como ela. Filho: grude, expressão do desejo materno ? O filho tem que entender que ela não tem mais tanto leite.

Marido fundamental: ajuda muito com as questões domésticas, e com o filho.

Dependência? Agora presente, mas um pouco mais afastado. Não podia participar no horário que ofereci a entrevista, e não quis outro horário.

Menos cansada e mais calma, Voz em tom mais baixo. Mais deprimida? Tudo melhora quando filho mais velho: melhor preocupa mais. Caminhando melhor. bebê dorme bem à noite.

Restauração narcísica.

Perda paulatina da

idealização? Perda do leite em excesso

representação de todas

as outras perdas?mãe

idealizada e bebê

ideal.Pressão: fazer viver bebê. 
Reverberacões da chegada do bebê

“Manhês"

Desamparo

\section{Contato com a} pesquisadora

\section{Isabela}

Avó materna quer deixar de fumar, sente saudade do neto, foto todos os

dias. Avó paterna palpita não sabe aconchegar o neto. Exige um novo reposicionamento, abrir mão de sua antiga vida. Não se imagina mais sem o filho.

Mãe comunica em grande parte das vezes, com prazer e naturalidade.

Atenuado pelo apoio materno e marido.

Consegue levantar e

pensar nas questões que preocupam, não fica paralisada, as questões são móveis, se modificam no tempo.

Prazer no encontro comigo, aproveita dele somos nutridas

mutuamente por esses momentos. Não deixa que eles sejam

interrompidos. Terapia comigo?
Não parece vivenciar uma mudança significativa do começo para agora.

Turbilhão, mudança no

ritmo que não volta ao

padrão antigo, seu filho não parece ser

considerado como um ganho de prazer.

Fala em "manhês": talvez um pouco mecânica? em outros parece como uma certa defesa ao que esta me contando.

Talvez não atenuado. Lida com a angústia talvez

organizando atividades.

Voltou a trabalhar

investimento grande. Tentativa de

amortecimento dos impactos?

Contato com ganhos? Em alguma parte pode ter sido atingida por um outro olhar em relação às questões

\section{Carla}

Fala sobre o final da gestação, não fica normal, relatório recusado terá que refazê-lo. Impacto sofrido, não parece poder haver percepção de mudanças

significativas.Apesar de dizer que o choro diminuiu, que esta melhor do que 3 meses atrás.

Fala em "manhês" com o filho durante a entrevista.

Angústia um pouco prolongada? falta suporte? Ao mesmo tempo talvez: necessidade de fazer as coisas sozinhas. Não consegue pedir mais ajuda - por ex., pessoa que trabalha na casa.

Sou convocada:mostra seu bebê competente, sabe sentar, sabe brincar. Nosso último encontro: recebe com pesar. prolonga com mensagens enviadas depois de dois meses, até o bebê ir para o berçário energia sugada.

Debilitada quando $\mathrm{kg}$ depois que parou encontro e intimidade Entrar em contato: experiências tocam e nos ver. Tocadas pelo

\section{Vanessa}

Fala das acomodações que ainda terá que fazer. Sobre sair com o bebê, diz que ainda não incorporou em sua rotina, ainda não sabe sair co ño mala, mas não sabe como se portar. Sair para o mundo implica inúmeras coisas: por exemplo, perder 0 ambiente protegido, perceber suas necessidades reais e as do filho, conhecendo-o na realidade da experiência.

Bebê dormiu em grande parte da entrevista: a mãe falou em "manhês" com o filho, denota muito prazer nessa conversa.

Desamparo centrado na amamentação? Talvez sinta-se assustada com a voracidade do filho.

Leite diminui até secar amamentava, ganhou 3

Aproxima-se e preserva 0

portunidades de pensar? reverberam. Última: bom porque eu iria terminar, e uim porque não íamos mais encontro: agradecimento e prazer em me conhecer.
O descentramento necessário que precisou fazer com a chegada de seu filho. E a questão de perceber-se insegura, de ir testando por exemplo,

sair com seu filho sozinha.

Apesar de ser protocolo d pesquisa:muito bom quando vou lá, sentirá falta. Questão corte e da separação comigo: não será nosso último encontro? Convida para tomar café quando eu quiser. Quem sabe elas não "passam" comigo qualquer dia. Deseja bom dia das mãe atrasado. 


\section{capítulo 6 \\ Discussão geral}

\section{Os caminhos da pesquisa}

Depois de muitas reflexões acerca do material recolhido nas entrevistas, formulamos algumas conjeturas mais gerais a respeito dos estados psíquicos da mulher durante o pós-parto e os possíveis recursos e caminhos para lidar com o trabalho psíquico imprescindível para a construção da parentalidade, considerando o confronto com os lutos concernentes a esse processo.

Notamos que o processo de parentalização inclui um trabalho de assimilação de sustos e impactos e com o que chamamos as dores e amores, presentes ao longo desse período. É no confronto com esses elementos que os lutos aparecem e podem ou não ser elaborados. Nesta discussão, procuramos mostrar como essas questões vão aparecendo nos diversos momentos da pesquisa e como a mãe pode contar com o ambiente para ajudá-la nessa tarefa.

De outra parte, como pesquisadora, fui construindo minhas ponderações, e esta discussão se forja a partir da intersecção dessas trilhas. Dados o acúmulo de material de pesquisa e a inúmeras impressões, sensações e impactos, fizemos algumas escolhas, reflexos do que foi possível pensar sobre todo esse universo de questões. O caminho apresentado aqui me pareceu factível, fruto também da elaboração que foi possível nesse percurso.

Assim, destacamos não só pontos que julgamos representativos do movimento individual de cada participante, mas algumas similaridades que nos permitam compará-las e entender os dinamismos psíquicos ao longo desse processo de construção da parentalidade.

As reflexões foram agrupadas pelo momento em que se tomaram as entrevistas.

Antes do encontro propriamente dito, entendemos que o primeiro ponto a considerar é a maneira como aceitam participar da pesquisa. 


\section{Aceite do pedido de participação na pesquisa, demanda latente e escassez de mecanismos de suporte social na atualidade}

Acreditamos que haja uma espécie de triagem natural dos participantes de um dado estudo; no mínimo, pode-se pensar que, quando alguém se dispõe a fazer parte de uma pesquisa, tem algumas razões para isso. Entre as mulheres que compuseram nossa amostra, cada uma teve seus motivos íntimos e pessoais, e não conseguiríamos esgotar essas possibilidades, mas apresentamos uma leitura que nos parece plausível.

Como já disse, eu temia que fosse difícil compor minha amostra, pois supunha uma resistência sobretudo ao encontro na primeira semana após o nascimento do bebê. Pensava: "Quem, em sã consciência, abriria a porta de sua casa a uma desconhecida, uma semana após o nascimento de seu filho?".

Uma forma de contornar esse problema era conhecer as mulheres ainda na gestação. Depois, essa decisão se provou acertada também porque nos permitira observar como caminhava a gravidez do ponto de vista psíquico, a relação que a mulher estabelecia com o bebê em seu ventre e em que circunstâncias da vida da mãe e do casal chegava a criança. Esse novo elemento se mostrou valioso para a pesquisa, como veremos.

Entendemos que o aceite da participação tem a especificidade de como cada mulher significou internamente o pedido, mas todas, de alguma forma, com menos ou mais resistência, não só aceitam participar como aproveitam esse espaço, que percebem ser de escuta e atenção, nesse momento específico de gestar um bebê e dos primeiros tempos da relação com ele.

Assim, ao contrário do que eu receava, algumas participantes atendem ao pedido de saída, por entendê-lo como uma grande oportunidade. Outras parecem hesitar um pouco no começo, provavelmente pelo que a experiência tem de nova e desconhecida, mas gradativamente vão usufruindo desse lugar que se thes oferece. Não me escapa a diferença entre o que eu temia e o que acabou acontecendo: parece que havia uma demanda latente dessas mulheres, que queriam ser ouvidas e acolhidas em suas mais íntimas angústias e incertezas. Entendo que essa 
demanda se deva à escassez de mecanismos de suporte social na atualidade nesse período particular da construção ou da ampliação de uma família.

Largamente discutida na literatura, a percepção de suporte social pela mulher desde a gravidez é considerada um importante fator de proteção contra a depressão pós-parto (Konradt et al., 2011). Os autores também destacam a necessidade de atuarmos preventivamente desde a gestação oferecendo às gestantes uma atenção ampliada; não só médica, mas também de psicólogos e enfermeiros, cujo papel é igualmente fundamental, e essas três modalidades profissionais são capazes de propor eficientes programas preventivos em saúde pública.

O apoio social percebido pela mãe também é destacado no estudo de Fonseca et al. (2010): quanto mais amparada afetiva e materialmente pelo entorno, mais ela é capaz de organizar os cuidados com a criança e de respeitar suas necessidades individuais e é maior também a responsividade do bebê; além disso, os autores mencionam a função protetora desse apoio contra sintomas depressivos.

Outro estudo importante no tema é o levantamento bibliográfico realizado por Schwengber e Piccinini (2003), que destacam a combinação de fatores de risco para a ocorrência da depressão puerperal, sendo de ordem biológica, obstétrica, social e psicológica (Cooper; Murray, 1995; ${ }^{37}$ Reading; Reynolds, $2001^{38}$ apud Schwengber; Piccinini, 2003). Os autores citam vários estudos que enfatizam a associação do quadro com a fragilidade do suporte oferecido pelo meio, pelo companheiro ou por outras pessoas (Beck, 2002; ${ }^{39}$ Beck; Reynolds; Rutowsky, 1992; ${ }^{40}$ Brown et al., 1994; ${ }^{41}$ Deal; Holt, 1998; ${ }^{42}$ Kumar; Robson, $1984 ;{ }^{43}$ Pfost; Stevens; Lum, 1990; ${ }^{44}$ Romito; Saurel-Cubizolles; Lelong, $1999^{45}$ apud Schwengber; Piccinini, 2003).

\footnotetext{
${ }^{37}$ COOPER, P. J.; MURRAY, L. The course and recurrence of postnatal depression: evidence for the specificity of the diagnostic concept. British Journal of Psychiatry, n. 166, p. 191-195, 1995.

${ }^{38}$ READING, R.; REYNOLDS, S. Debt, social disadvantage and maternal depression. Social Science \& Medicine, n. 53, p. 441-453, 2001.

${ }^{39}$ BECK, C. T. Postpartum depression: A metasynthesis. Qualitative Health Research, n. 12, p. 453472, 2002.

${ }^{40}$ BECK, C. T.; REYNOLDS, M. A.; RUTOWSKY, P. Maternity blues and postpartum depression. Journal of Obstetric. Gynaecologic and Neonatal Nursing, v. 21, n. 4, p. 287-293, 1992.

${ }^{41}$ BROWN, S.; LUMLEY, J.; SMALL, R.; ASTBURY, J. Missing voices: the experience of motherhood. Nova York: Oxford University Press, 1994.
} 
Visando identificar os fatores de risco associados à depressão puerperal, Cruz et al. (2005) encontraram apenas uma correlação positiva no que tange à questão do suporte social e emocional no importante momento de transição que representa a maternidade.

Soma-se a tal importância, o viés destacado por Rochette (2003), como vimos, sobre o relevante papel que o grupo exerce na transição da gestação para o puerpério, assim como do nascimento ao acolhimento da mulher e do novo membro na sociedade. Igualmente importante é que esse acolhimento se faça por meio de rituais ou de novos dispositivos forjados pela cultura, de modo a cuidar da família nesse período de passagem.

Além de todos os sentidos que o blues pode assumir, como vimos no capítulo 3 , talvez ele possa significar ainda um pedido especial e latente de cuidado e de sustentação nesse momento delicado, quando têm lugar um importante remanejamento psíquico na mulher e o impacto do nascimento de um bebê na família.

Lembrei-me da função de reclamação destacada por Alvarez (1994); diz a autora que, com crianças gravemente enfermas, o trabalho do psicanalista muitas vezes é o de resgatá-las psiquicamente, reclamá-las e "trazê-las de volta" ao contato, e não apenas contê-las. Embora se trate aqui de algo bastante diverso, essa associação vem a propósito de que a mãe e a família demandam de forma latente a contenção de suas angústias, mas muito raramente pedem cuidado emocional, provavelmente em razão da idealização do papel materno em nossa cultura, ou por uma certa falta de "significação psíquica" para os fenômenos na atualidade. Hoje, dificuldades ou desequilíbrios soem ser explicados preferencialmente por carências bioquímicas.

\footnotetext{
${ }^{42}$ DEAL, L. W.; HOLT, V. L. Young maternal age and depressive symptoms:results from the 1988 National Maternal and Infant Health Survey. American Journal of Public Health, v. 88, n. 2, p. 266-269, 1998.

${ }^{43}$ KUMAR, R.; ROBSON, K. A prospective study of emotional disorder in pregnancy and the first postnatal year. British Journal of Psychiatry, n. 144, p. 35-47, 1984.

${ }^{44}$ PFOST, K. S.; STEVENS, M. J.; LUM, C. U. The relationship of demographic variables, antepartum depression and stress to postpartum depression. Journal of Clinical Psychology, n. 46, p. 588-592, 1990.

${ }^{45}$ ROMITO, P.; SAUREL-CUBIZOLLES, M. J.; LELONG, N. What makes new mothers unhappy: psychological distress one year after birth in Italy and France. Social Science \& Medicine, n. 49, p. 1651-1661, 1999.
} 
Szejer (1999a) menciona a necessidade de acolhermos essas demandas latentes, indicando uma necessária tradução do que seria esse trabalho de contenção das angústias suscitadas na perinatalidade.

É interessante pensar que, ao acolher meu pedido, as mulheres talvez tenham ido de encontro a sua própria necessidade de ser acolhidas, e podemos supor ainda que os diferentes graus de resistência talvez sejam movimentos naturais de toda mulher que gesta e cuida de um bebê nos primeiros tempos de vida. Em virtude de vários fatores, como vimos, mas fundamentalmente em decorrência do estado de hipersensibilidade materna que Bydlowski $(2002$; 2007) chama de transparência psíquica e de todos os remanejamentos a que a mulher fica sujeita na gestação, no puerpério, na construção da parentalidade e na administração da transmissão psíquica entre as gerações que se dá quando surge um novo membro.

Ao longo das entrevistas, a fala das participantes deixa evidente que os impactos não se centram apenas em sua vivência e que realmente há um total remanejamento familiar com a vinda de um bebê. $O$ pai e os outros filhos são profundamente afetados por essa chegada, e esse dado foi reiteradamente encontrado na pesquisa.

A hipótese da existência de uma demanda latente de cuidados, de escuta e de contenção de angústias nesse momento da perinatalidade também foi confirmada ao longo do contato com as participantes, como veremos em seguida.

Antes, porém, discutiremos brevemente um elemento que, apesar de não estar entre os achados da pesquisa - nenhuma das participantes contou ter recorrido a ele -, é interessante para o nosso tema: trata-se do fenômeno nomeado por seus usuários blogosfera materna.

Desde o início de meus estudos da maternidade, da construção da parentalidade, do vínculo pais-bebê e da incidência da depressão puerperal na mulher, percebo que a web tem sido um meio do qual mães e pais se valem no momento da perinatalidade, e ela ilustra duplamente um fenômeno peculiar da atualidade: de um lado, as falhas dos mecanismos de contenção social para esse período e, de outro, a tentativa de criá-los pela blogosfera materna. 
Os blogs são a expressão do pensamento ou da opinião de um autor; já a blogosfera é a representação de um fenômeno social mais abrangente, fruto de interconexões entre blogs, criando uma espécie de cultura própria.

$\mathrm{Na}$ blogosfera materna, o que parece estar em jogo é justamente a possibilidade de, nas palavras dos usuários, "saber que não estão sós", dividir e compartilhar dúvidas, angústias, medos, alegrias e aprendizado. Geralmente, a motivação para criar um blog na esfera materna é poder conversar com pessoas que estejam passando por situações semelhantes, desde a questão da infertilidade até a perda de um bebê, passando pela trabalhosa construção da parentalidade.

O adjetivo "materna" não exclui os pais, o que leva a pensar na abrangência do fenômeno. O compartilhamento da angústia no grupo é interessante e certamente indica que existe essa demanda, mas, se em alguns casos o acolhimento do grupo virtual é suficiente para supri-la, em muitos outros, acredito que não dispensa o necessário aporte profissional, e os pais seguem sem cuidados efetivos, eventualmente com o prolongamento de sua angústia e de outros quadros sem 0 devido tratamento.

E o recurso é interessante também para casais de pais. Vendo-se entre iguais e protegidos pela virtualidade da blogosfera, os pais da web se sentem mais à vontade para pedir ajuda e expor suas dificuldades e dúvidas, mas a necessidade maior parece mesmo ser a contenção das angústias.

Considerando todos esses fatores, passo agora a um levantamento do que foi observado de maneira geral nos encontros com as participantes da pesquisa, começando pelo primeiro, quando ainda eram gestantes, e me permitiu conhecer essas mulheres.

\section{ENCONTRO GESTACIONAL}

$\mathrm{Na}$ entrevista gestacional, escolhi três vértices que me parecem fundamentais e ilustrativos do que mais me chamou atenção e fornecem elementos preciosos para a discussão: 


\section{- Pré-gravidez: o caminho das perdas no período pré-gestacional}

Quando entendido como parte de um processo, esse período inclui e marca a construção da parentalidade, tingindo a dinâmica da relação do casal com o bebê.

No material das entrevistas em geral, percebi uma referência constante a algo que se processava nas experiências vividas ao longo do percurso de se tornarem mães, mesmo ainda antes de engravidarem. Esse caminho não era vivido sem muitos adiamentos e desvios e depois, já na gestação, com algumas intercorrências. Essa questão me chamou atenção e, apesar de se ter manifestado de forma diferente em cada uma das participantes, me alertou para a necessidade de escutar cuidadosamente e procurar compreender o valor intrínseco dessas falas no que tangia a perdas e a sua necessária elaboração.

Algumas falas indicam perdas no período pré-gestacional, como os adiamentos da gravidez de Isabela e Vanessa, que mostram como pode ser angustiante essa espera. Ambas tiveram certa dificuldade de engravidar quando gostariam, deflagrando o risco de não conseguir, a "esperança contida no sapatinho" que Vanessa fez quando começou a investir no desejo de ser mãe (em sua face consciente) e o adiamento da entrega aos avós até saber que realmente estava grávida. Algumas idas e vindas, esperanças e dúvidas pressupõem sucessivas elaborações e novos reinvestimentos até a concretização.

Por outro lado, Gabriela indica as perdas e mudanças às quais ficou sujeita assim que a relação com seu marido ganhou um estatuto mais sério, tendo que abrir mão de sua liberdade pessoal e mudar de país. Parecia sinalizar que as relações impõem uma necessidade de investimento e dão certo trabalho; deve-se abrir mão de algumas coisas para obter ganhos nesse espaço compartilhado que representa a relação com um outro.

Érika e Carla contam que a segunda gestação remete, de certa forma, à história da primeira. A necessidade de repouso absoluto que tiveram que fazer e o parto traumático que Carla vivenciou deram à experiência atual uma aura de preocupação e atenção. 
Assim, vemos que nesse período pré-gravídico, quando se anuncia o projeto de um filho para seus pais, já se põe em movimento um delicado exercício de elaboração de perdas e ganhos que podem voltar no processo de parentalização.

\section{- Gravidez: sobre o susto e a surpresa}

É interessante que, apesar de todas terem sido planejadas, a consumação da gestação de cada uma das mulheres de nossa amostra implicou um susto e certa surpresa, levando-me a pensar se - no horizonte materno e no paterno - essa realidade já não impõe ao psiquismo uma determinada forma de intensidade quando o encontro com o projeto de ter um filho caminha para a efetivação.

O susto que o teste de gravidez traz seria uma tradução do que pode representar o projeto de ter um filho sair do plano da imaginação e do desejo para a concretude de um ser que chega. Parece ser também um momento de passagem, de transição - tal como acreditamos ser o parto -, anunciando desde aí uma gradativa necessidade de adaptação do psiquismo materno e paterno: não há mais apenas o casal.

Uma ilustração interessante da surpresa de estar grávida é a fala de Vanessa: não acreditando que estava grávida, ela procurava se certificar fazendo repetidos exames.

A mescla de susto e surpresa aparece também em Gabriela, ilustrada por certa antecipação do tempo para engravidar. Foi muito mais fácil do que ela imaginara, e ela também custou a acreditar no teste.

Supomos que sempre haja um sobressalto, e se, no íntimo, uma parte da mulher duvida que possa gestar um bebê - como Gabriela, no momento em que o teste dá positivo -, junto com a alegria, alguma coisa irrompe subitamente. A partir do positivo do teste, surge um outro no psiquismo e no corpo materno. Um tanto de invasão parece se presentificar nesse momento, daí seu efeito assustador, repentino e excessivo. Sendo inerente o impacto, ele traz medo e abalo e é surpreendente, uma vez que a presença de um outro dentro de si é, ao mesmo tempo, admirável e espantoso. 
Acredito que a surpresa do positivo do teste se ligue ao fantástico da experiência de portar um bebê no ventre, que, por ser altamente complexa, não se resume facilmente. Além de uma possível felicidade - eventualmente a resposta a desejos antigos que se reatualizam - pode ser também uma novidade por excelência, por esse fabuloso acontecimento que se realiza na concretude do filho no ventre.

Por ser uma experiência tão grandiosa, talvez a gravidez contenha sempre uma porção hesitante. Carla ilustra o quanto ela é importante e valorizada, mas inclui um grande risco. Parece haver uma linha muito tênue entre a concretude do bebê e seu encobrimento pelo ventre. Esse caminho até o nascimento pode às vezes ser vivido de forma muito angustiante. Gravidezes tumultuadas do ponto de vista físico podem ilustrar talvez esse risco de perder algo tão forte e ambiguamente desejado.

A ambiguidade do desejo se justifica em parte pelo total remanejamento psíquico de quem gesta e dá à luz, largamente comentado na literatura (Langer, 1986; Brazelton; Cramer, 1992; Aulagnier, 1990; Winnicott, 2000a; Bydlowski, 2002), bem como pelos impactos e perdas a que a mulher fica sujeita, como temos visto aqui.

O susto, a surpresa e o risco parecem marcar o psiquismo de quem engravida, e as participantes o demonstraram de diferentes formas. Mais patente em algumas mulheres, disfarçados por potentes mecanismos de defesa em outras como parece ser o caso de Érika tentando amortecer o impacto da novidade de ter mais um filho e tudo o que ele pode trazer - com o "saber ser mãe" que ela aprendeu na primeira experiência.

Os riscos de perder o bebê na gestação são reais, mas também podem traduzir um perigo de outra natureza diversa, talvez apontando a questão do desamparo humano e da morte. 


\section{- Antecipação do bebê e do papel materno: o que antecipa a antecipação? Para que prepara a antecipação?}

Pensamos que a antecipação do bebê, muito comentada na literatura (Brazelton; Cramer, 1992; Aulagnier, 1990; Winnicott, 2000a; Missonier, 2004; Aragão, 2011), e a da mulher como mãe podem ser muito diferentes, dependendo da pessoa. Como vimos, algumas idealizam muito o bebê e a si mesma; dessa forma, o vínculo com o filho pode ser feito de modo a esperar que ele preencha tudo na mãe, ou ser importante por ter assegurado um investimento materno, ou nem figurar nos investimentos da mãe, em que se vê uma antecipação insuficiente etc.

Podemos ter indícios da antecipação que as mulheres fazem quando ainda gestam o bebê com expressões sutis como fez Isabela. Quanto mais cresce seu filho em seu ventre, mais aumenta sua ligação com ele, e ela consegue também desinvestir um pouco de sua carreira para destinar ao bebê: arruma seu quarto, compra-lhe roupas. Outro indício importante é não vê-lo como alguém a tamponar todas as lacunas de sua vida, não se ver apenas mãe, apesar de ter investido muito nesse projeto. Esse conflito se mostra importante porque parece refletir uma preparação para sua vida posterior e ilustra a forma pela qual Isabela tenta se preparar para o que vem, numa tentativa de não ser pega de surpresa - o que parece ser característico de seu funcionamento psíquico.

Um dado que se mostrou importante é a possibilidade de desinvestir parcialmente da vida anterior à gestação para destinar esse investimento ao bebê, reservando-Ihe um lugar privilegiado e necessário. Parecem ser as formas de antecipação do bebê e do papel materno que podem fornecer sinais de uma dificuldade exacerbada de regredir e se retirar nesse momento.

Os casos de Gabriela e de Érika exemplificam como pode ser árduo o processo de regressão e retirada característica do estado gravídico. Gabriela se ressente da sensibilidade exacerbada, do choro e do muito sono no início da gravidez. Érika, por sua vez, mostra dificuldade de diminuir seu ritmo de trabalho, de paulatinamente ir se afastando - o que depois Ihe foi imposto por um risco de perder o bebê. 
Esses exemplos mostram que as características desse período - como a regressão, a hipersensibilidade decorrente de um psiquismo em transparência e a necessária preocupação materna primária (Bleichmar, 1994; Raphael-Leff, 1997; Winnicott, 2000a; Bydlowski, 2002; 2007) - podem ser significadas como perdas em torno da maternidade e, em algumas mulheres, podem encontrar muita resistência, dificultando as necessárias elaborações em torno dessa vivência desde o início da gestação e podendo prolongar-se pelo puerpério.

Pensamos também, que ao considerar o lugar privilegiado que a profissão tem hoje para a mulher, podemos imaginar que, para algumas, a dificuldade de paulatinamente desinvesti-la pode ser um movimento de resistência frente a esse momento hipersensível de sua vida, no qual seu psiquismo encontra-se em transparência, tal como postulou Bydlowski (2002; 2007). Na cultura, não temos suportes para esse período ser atravessado da forma mais amena possível; pelo contrário, as altas exigências de performance e sucesso não poupam as grávidas, mas as sobrecarregam ainda mais.

Por sua vez, Carla é um exemplo de como a antecipação se apresenta pela via da imaginação e testemunha que só no sexto mês de gestação conseguiu "ver" o filho, levando-nos à hipótese de que isso tenha sido possível quando o risco de perder o bebê já era menor, ilustrando mais uma vez como a vida e a morte estão fortemente vinculadas, como duas faces da mesma moeda. E é nesse momento, quando um filho cresce e nasce, que ela se apresenta claramente.

No entanto, também parece imprescindível atentar para a qualidade do investimento no filho. Vanessa parece indicar um lugar muito idealizado para o bebê: alguém que lhe é muito familiar, muito parecido com ela, um "ótimo filho". Com esse lugar narcísico reservado e uma gravidez muito valorizada e vivida sem intercorrências, ela se nutre de poder e de força, e o desamparo não tem vez. Talvez essa representação antecipada tão idealizada do bebê indique, de fato, a dificuldade que pode significar fazer frente ao tão penoso desamparo inicial.

Sabemos que, no início, a idealização do bebê é um lugar-comum na realidade materna, fruto do narcisismo transvasado necessário para alimentar o projeto de filho (Freud, 2010a; Bleichmar, 1994), No entanto, apareceu a importância 
de acompanhar a transição dessa idealização inicial maciça para um salutar investimento na relação com a individualidade do bebê, juntamente com um não saber sobre ele, com o desconhecido e novo que ele a princípio representa.

Assim, entendemos a antecipação como um fenômeno tingido pelas cores do narcisismo e que reflete o caminho pelo qual o vínculo com o bebê se está processando, erguendo os tijolos da construção da parentalidade. Constatamos que, apesar de ser uma preparação para o que está por vir, ela nunca se pode dar totalmente a contento; alguma coisa sempre lhe escapa, e, de certa forma, tem que escapar, para dar espaço à experiência real que sobrevém.

\section{PRIMEIRO ENCONTRO APÓS O PARTO}

As primeiras entrevistas após o nascimento forneceram um precioso material para esta discussão. Elas aconteceram uma semana após o parto, exceto no caso de Gabriela, que nos recebeu no $26^{\circ}$ dia. Depois de um vasto exercício reflexivo, coligimos os elementos encontrados em dois grandes pontos nodais:

\section{- O parto ou sobre o divisor de águas}

A experiência do parto parece ser um divisor de águas: simboliza um momento de transição por excelência, além de representar a concretude do nascimento, repleto de sensações e sentimentos. Pensamos que seja, por si só, uma aventura transbordante, mas, depois da análise do material, chegamos a alguns elementos importantes sobre o motivo pelo qual se devem examinar atentamente esse momento e as experiências em torno dele, prestando à mulher e à família uma assistência mais alinhada com suas reais necessidades.

Embora o objetivo aqui não seja quantificar os fenômenos estudados, é notável que todas as mulheres de nossa amostra se tenham submetido a cesarianas. Esse dado remete ao âmbito altamente complexo e discutido sobre uma cultura da cesárea no Brasil, reflexo de uma igualmente complexa situação social: 
A medicalização do parto é um reflexo da medicalização social, descrita como processo sociocultural complexo que transforma em necessidades médicas as vivências, os sofrimentos e as dores que antes eram administradas no próprio ambiente familiar ou comunitário. A medicalização transforma culturalmente as populações, com um declínio na capacidade de enfrentamento autônomo das dores e adoecimentos (Tesser, 2006). ${ }^{46}$ Esta contribuiu para o declínio da capacidade da mulher de lidar com o fenômeno do parto, sua imprevisibilidade e as dores do trabalho de parto (Leão et al., 2013).

Por ser um tema altamente intrincado, não nos parece fruto de um único determinante, mas de uma situação social muito mais ampla. No entanto, pensamos que vale enfatizar o uso indevido dos avanços médicos, que podem substituir indevidamente outros dispositivos de cuidado, sejam eles oferecidos pelo grupo social, sejam outros saberes, como nos parece o caso dos conhecimentos e da assistência oferecida pela psicanálise.

Assim, a nosso ver, a medicalização do parto pode ser entendida pela face da intolerância e da fuga das dores, sejam elas físicas ou - principalmente - psíquicas, em nossa sociedade atualmente.

Dito isso, voltamos aos achados da pesquisa e à compreensão do parto como um evento transbordante. A vivência emocionante implicada nele é ilustrada pelo relato de algumas participantes: "não ter como descrevê-lo", ser uma "experiência mágica" ou a "experiência mais bonita" vivida. E temos ainda sua representação como uma espécie de susto.

As participantes citam a experiência do parto como algo que as impactou intensamente, e não só pelos aspectos positivos, mas por uma qualidade desse suposto transbordamento a que a mulher fica sujeita. O susto relatado por Gabriela, que viu chegar a hora e não se sentia preparada; a grande preocupação de Vanessa e a vontade de deixar o bebê mais um pouquinho em seu ventre, indicando o caráter de risco que há na transição do parto, tanto para o bebê quanto para a mãe. Carla, impactada pela experiência traumática no primeiro parto com os medicamentos

\footnotetext{
${ }^{46}$ TESSER, C. D. Medicalização social: o excessivo sucesso do epistemicídio moderno na saúde. Interface, Botucatu, v. 10, n. 19, p. 61-76, 2006.
} 
anestésicos, testemunha com seu corpo a ameaça que esse parto representa para ela e se sente muito mal durante e após o parto, apesar de ter podido aproveitar um pouco mais essa segunda oportunidade. Érika, por sua vez, representa o impacto do parto pelo "horror da anestesia", pela falta de controle, sem sentir suas pernas. Já Isabela, que também nos fala do horror, pôde senti-lo atenuado pelas experiências gratificantes. Embora não tenha tido coragem de fazer um parto normal, por medo da episiotomia, ela consegue viver a experiência do nascimento do filho de modo a aproveitá-la. Apoiada na confiança em sua médica e no suporte verdadeiro do marido, relata uma vivência transformadora, apesar de todo o impacto.

Soifer (1992, p. 29) já comentava que no parto apareceria de forma manifesta, pela primeira vez, a ideia da "vida com limites precisos", ou da própria morte, o que talvez explique condensadamente a ansiedade de estar cedendo parte da própria vida no medo de morrer no parto.

Além de ser um atravessamento de fronteiras, o parto implica um risco, representado não só pela vida e pela morte e pelo estranho, na figura de um filho que nasce, mas também por uma vida diferente, que se apresenta a partir daquele momento, para o bebê, para a mãe, o pai e a família. Sendo sempre da ordem do inesperado, daquilo sobre o que não temos controle, presentifica o desamparo por excelência.

\section{- Sobre as dores e os amores}

Sob essa ótica, procuramos articular e privilegiar os aspectos relativos a perdas e ganhos que são vividos na elaboração das principais experiências que se destacaram nessas entrevistas. Dentre os principais temas presentes nessa fase da relação mãe-bebê, organizamos nossas reflexões nos seguintes tópicos:

- construção do vínculo com o bebê real e da parentalidade

- impactos do nascimento para a família

- amamentação 
- sensibilidade e tristeza

- suporte e apoio, lugar do pai

- o bebê

\section{Minha experiência sobre as dores e os amores junto às participantes}

Minha experiência no encontro com as duplas mãe-bebê após o parto foi fascinante. De certo modo, também senti as reverberações desses nascimentos, seja dos bebês ou das mães, não importando o fato de algumas não estarem inaugurando seu papel materno. Com cada dupla, vivenciei algo único, e pensei que, a cada nascimento, uma mulher também parece experimentar algo de natureza diversa com cada um de seus filhos. Embora o primeiro filho apresente a parentalidade a sua mãe e/ou a seu pai, os outros também mostram-na de forma exclusiva, específica daquele encontro particular, denotando a riqueza dos acontecimentos humanos.

Quando essas mulheres compartilham comigo o nascimento de seus filhos e a experiência de se tornarem mães, eu tomo parte de algo de valor inestimável, fazendo-me testemunha de suas dores e de seus amores. Vivo com as duplas, em maior ou em menor grau, uma experiência de intimidade, de estreita vinculação, o que talvez sugira que essas mulheres tenham encontrado um ambiente propício não só para dividir comigo algo tão íntimo, como indica o material, mas para ter um continente favorável à expressão de suas angústias, tão necessário nesse período hipersensível e de passagem que representa o puerpério, chegando, com algumas delas, à possibilidade de simbolizar tal experiência.

\section{Dores no corpo e na alma}

As dores são vividas tanto no corpo como na alma. Algumas participantes puderam experimentá-las livremente e compartilhá-las comigo; em outras, essa vivência parecia obscurecida por uma espécie de defesa contra o sofrimento. Penso que Isabela e Érika demonstram-no de formas diametralmente opostas. 
Isabela parece simbolizar emblematicamente o quanto a parentalidade, mesmo desejada, pode implicar uma potência excessiva e com matiz traumática, se não encontrar recursos - tanto internos, da mulher, quanto externos, no companheiro e no grupo, o familiar ou outro. Os elementos desse material foram preciosos pela possibilidade de uma reflexão que julgo ser um condensado ${ }^{47}$ do que parece estar em jogo na construção da maternidade: perdas, impactos e sofrimentos, bem como o processamento das perdas e as decorrentes experiências de ganho.

Isabela divide comigo e sugere o quanto as dores, físicas ou não, são parte da construção do papel materno, incluindo o susto e o impacto da metamorfose que o nascimento traz ("muda o corpo, muda toda a sua vida!"), refletindo o caráter inesperado do nascimento e demanda imperiosa do recém-nascido, a quem se deve ajudar a viver.

O susto e o impacto sentidos simbolizam o caráter excessivo da maternidade, quando as dores e as perdas, que pareciam não ter lugar no projeto anterior, exigem da mulher não só uma desidealização como uma rápida elaboração e adequação de seu papel materno. As falas de Isabela ilustram o impacto: "eu não esperava isso", "está sendo muito mais difícil do que imaginava!".

A exigência da responsabilidade de cuidar parece se reavivar junto com a regressão e o psiquismo em transparência, característicos do período, e o desamparo materno, incrementado pelo desamparo advindo do bebê: Isabela vê o olhar assustado de seu filho, identifica-se com ele e o ampara.

A maternidade parece ser sentida como excessiva, não havendo preparação possível, pois ela reflete uma ruptura importante no funcionamento psíquico anterior à gestação. Como já comentamos, no decorrer da gravidez, vai havendo uma preparação que nunca é totalmente eficiente, algo sempre escapa, pois é na presença do bebê de carne e osso e a partir das exigências que ele impõe aos pais - seja de garantir sua sobrevivência, seja de reavivar e ter que lidar com o infantil em si mesmos - que o excesso se faz presente.

\footnotetext{
${ }^{47}$ Refiro-me à leitura que fui capaz de fazer sem poder abarcar todo o universo da vinda do filho para cada mulher em particular. Alternativamente, estabeleci linhas gerais possíveis, fruto da análise do material de pesquisa e das experiências vividas nos encontros.
} 
Esses primeiros dias, que representam a transição para a parentalidade nas primíparas e sua complexificação no caso das multíparas, são uma dura prova para a família, e o impacto não é sentido só pela mãe. Isabela conta que seu marido "enlouqueceu", com a responsabilidade brutal pelo "sustento da família", e que virou um "leão de chácara". Carla, que em algum momento também usa esse verbo ("enlouquecer") para se referir ao que aconteceu a seu marido, se ressente de sua ausência, diferentemente do que sentira no primeiro parto.

Isabela pôde oferecer ao filho um cuidado sensível, por estar intimamente ligada a ele. Ao poder entrar em contato com suas dores, seu não saber e, em última análise, seu próprio desamparo, pôde amparar sensivelmente seu filho. Pôde contar com a função continente de sua mãe, com a qual foi se identificando em sua função materna. Deixando-se levar pelo blues, chora, vive intensamente a difícil experiência pela qual não esperava, enriquecendo e sendo enriquecida pela vivência da maternidade e tudo o que ela comporta, mas fundamentalmente podendo oferecer ao filho cuidados com uma qualidade especial.

Por outro lado, em algumas mulheres, a experiência de intensidade que representa a vinda de um filho, simbolizada de forma brutal e invasiva, parece precipitar formas defensivas de lidar com tamanho impacto. O material de Érika pode representar essa circunstância: seu estado agitado em meio a uma casa em reforma, com muito barulho e poeira, parece uma forma de se desvencilhar das dores decorrentes do nascimento, e penso que indica a intensidade do impacto e do sofrimento, muitas vezes transbordante, reverberando em algumas dificuldades. Uma delas parece ser o temor de investimentos privilegiados no filho: ela fica bastante preocupada com o ciúme de seu filho mais velho, que passa a se comportar de modo diferente do habitual, ressentindo-se da vinda do irmão. Pode também aparecer em sua percepção do envelhecimento de seus pais, que agora demandam investimentos e cuidados diferenciados, traduzindo o curso natural da vida.

Atualmente, o "culto à felicidade e ao sucesso" não deixa espaço para a tristeza ou para as dores, às quais são fortemente repelidas por todos, criando contra elas uma intolerância cada vez maior. Soma-se a isso a já comentada 
idealização da maternidade, na qual é descabido sentir algo diferente de contentamento quando nasce um filho.

Érika parece refletir essa situação: a tristeza fica repelida, o fato de não relatar nenhum episódio de choro ou de maior sensibilidade não a isenta das reverberações do impacto do nascimento, em si mesma e na família; pelo contrário, percebemos o tamanho impacto sua posição solitária para dar conta dele.

Em algumas mulheres, essa situação também pode levar a uma espécie de distância e dissintonia com o bebê; nesses casos, os cuidados e a amamentação, por exemplo, são experimentados com certo prejuízo da vivência de prazer. Há aí o risco de se configurar um quadro descrito na literatura como uma depressão mascarada, latente, insinuando-se apenas por meio dos sofrimentos somáticos e da astenia (Kreisler, 1999; Golse, 2003a), representada por uma perda ou diminuição das forças, algo próximo à "perda do vigor". Pela especificidade desse momento, é difícil identificar um caso desses, pois todos são muito exigidos e ficam muito cansados, incluindo os pais, na adaptação que precisa ocorrer após o nascimento.

Algo próximo disso é a chamada depressão sorridente (Boukobza, 2002; Aragão 2011), também mascarada ou encoberta, na qual a mãe se esforça para negar o sofrimento exercendo normalmente suas atividades, mas com a vivência do prazer prejudicada. Isso leva as mulheres a uma espécie de relação de tarefa com seus filhos, da qual a libido fundamental na constituição do psiquismo infantil e da vida humana fica apartada ou comprometida. A dificuldade de entrar num estado saudável mais deprimido pode dificultar uma conexão íntima com o bebê.

A análise do material de Érika não permite afirmar que ela tenha tido uma depressão desse tipo, mas vi fortes indícios de uma dificuldade de entrar em contato com suas dores.

A amamentação também pode dar indícios de como caminha a relação. Se, por um lado, Isabela se ressentiu das dores nas mamas no início, quando elas se amenizaram, voltou a sentir prazer em amamentar, dizendo que fica namorando o filho enquanto ele mama. Érika, por sua vez, demonstra uma espécie de dificuldade em se conectar com o bebê: apesar de não ter nenhum problema em amamentar, às 
vezes não discrimina se o bebê está realmente com fome, o que a faz amamentá-lo de hora em hora.

Uma amamentação sem intercorrências mostrou não ser necessariamente indicativa de um vínculo harmonioso. Tanto o material de Érika quanto o de Gabriela levam a crer que, apesar de não apresentarem dificuldades ou conflitos significativos nesse quesito, a relação geral deixava ver pontos de desencontro entre a dupla mãe-bebê. Em Érika, a amamentação parece ser introduzida quando o bebê chora, e, em Gabriela, o desencontro na relação não parece afetar especificamente a amamentação.

A amamentação pode ser experimentada como uma metáfora da dependência absoluta do filho, no início, e, assim, representaria a exigência brutal, muitas vezes opressiva, de a mulher ter que dar conta da sobrevivência do filho sozinha e também um certo receio de fusão com o bebê. É o que Carla parece indicar: somado a um "bebê faminto", seu leite se torna escasso, e ela introduz o leite artificial.

Apesar de muito investida, a amamentação também pode representar, para algumas mulheres, não só uma exigência brutal - talvez também por receio de ficar para sempre fundida ao bebê (Monteiro, 2003) -, como, ao lado da idealização do papel materno, acarretar dificuldades no acerto entre as demandas do bebê e aquilo que a mãe lhe pode oferecer nesse momento específico. O caso de Vanessa ilustrar essa situação. Inicialmente, ela vive os intensos engasgos do bebê e depois passa a sentir-se insuficiente (o excesso vira falta). Exigida pela natural demanda do bebê e por si mesma, ela vive uma grande ansiedade, que, como sabemos, está estreitamente ligada à descida do leite.

Esses pontos sugerem que, muitas vezes, dificuldades na amamentação - 0 chamado "leite insuficiente" ou o "leite fraco" - podem representar a vivência materna sentida como opressiva e muito angustiante pelo fato de o bebê ser totalmente dependente, no início da vida, de alguém que o cuide, agravada pela falta de um entorno que ajude a suportar tais demandas e pela hipersensibilidade característica do período e de tudo o que ela pode envolver. Pelo contrário, o que 
vemos é uma cultura à amamentação a qualquer custo, negligenciando todos esses fatores que estão em jogo na vida do bebê e de sua família.

Concordo com Feliciano (2009, p. 74) quando diz que muitas mulheres se vêm exigidas a amamentar seus filhos para responder à demanda de nossa cultura de ser "boas mães", o que as leva muitas vezes a converterem a amamentação em "pura tarefa", desprovida de prazer.

Simbolicamente, o leite materno é a substância capaz de garantir a sobrevivência da criança. Assim, a introdução de fórmulas artificiais pode sugerir a entrada de um terceiro elemento e, em alguns casos, servir de alento materno, pela carência de alimentos capazes de ajudar a mulher na complexa tarefa de ser mãe, como temos visto neste estudo.

Acredito também que a amamentação é apenas uma das situações em que o caráter de tarefa se dá a ver, pois ele pode aparecer também nos cuidados contínuos: nas trocas, no banho, no brincar com o bebê e nas falas características da prosódia materna - o "manhês" -, que podem se reduzir a uma fala automática, desprovida de real prazer.

Por outro lado, como já comentamos antes, entendemos que o suporte de outras pessoas e o apoio do pai do bebê é extremamente relevante no início da vida do bebê na família, o que foi evidenciado no depoimento de Isabela e apareceu como falta em testemunhos como o de Gabriela.

Um ponto importante que resultou das reflexões em torno do material de Vanessa é a impossibilidade ou certa recusa de receber auxílio da mãe ou da sogra, sobrecarregando o marido. Isso me levou a pensar que esse suporte precisa ser não só qualitativamente significativo para cada mulher, como é algo sutil: mesmo que, do ponto de vista prático, se refira a cuidados com a casa, com a comida e mesmo com o bebê, fundamentalmente deve ser respeitoso o suficiente para servir de holding para a própria mãe e se alinhar a suas demandas nesse momento, para não piorar ainda mais a situação geral. 
E essa reflexão leva também a perguntar sobre a especificidade da introjeção da figura materna que fez cada uma das participantes, bem como sua identificação com o papel materno agora atualizado.

Aturdida pela angústia de não conseguir amamentar adequadamente seu bebê e pela dificuldade de se encontrar com seu bom objeto materno introjetado, Vanessa se sente muito invadida pela presença da mãe e da sogra. Parece senti-las como quem não ajuda, e, sobretudo sua própria mãe, como uma presença inoportuna: seus conselhos não são bem-vindos, e ela não é autorizada pela filha a, por sua experiência de ter sido mãe, ajudá-la a suportar esse lugar.

Com seu ressentimento pelo fato de o marido não poder estar sensivelmente presente nos primeiros dias do segundo filho como tinha estado nos do primeiro, Carla se sente mais desamparada e nos remete a outra questão: frente aos impactos do nascimento, os homens também reagem como podem. Preocupado com a segurança, a reforma da casa e as mudanças no trabalho, seu marido se afasta, de certa forma, do epicentro do fenômeno, para continuar cuidando da família - guardando uma distância. Já o marido de Érika prefere ajudar cuidando do filho mais velho, e o de Isabela - que, em seu dizer, "enlouqueceu" - mostra sua preocupação com o "sustento da família", refletindo os vários aspectos pelos quais os pais respondem.

Sensibilizadas por todas as questões já expostas, Isabela, Carla e Vanessa choram e se sentem abandonadas à própria sorte - mas não parecem estar reagindo pura e simplesmente aos conhecidos desarranjos hormonais do período puerperal. Apesar das dificuldades e das dores que sentiram, vivenciam os amores e a emoção ímpar de ter um filho. No entanto, apesar de também sofrer, Érika e Gabriela se mostram de outro modo. Érika tenta se proteger da tristeza tendendo a amortecer os impactos vividos, e Gabriela não nega o sofrimento, mas parece tão amalgamada com ele, que não logra tomar uma distância para pensar nele - ele the dói tanto que ela só quer deixar de senti-lo. 
Magagna (1992 ${ }^{48}$ apud Prat, 2008) ressalta o poder traumático que o nascimento de um filho pode ter para a mãe, em virtude da confusão e da perda da identidade anterior ao parto, somadas à consciência de sua responsabilidade de cuidar. Penso também que se imporia aí o tema da transmissão psíquica entre as gerações, assoberbando ainda mais esse psiquismo, compondo-se com a diluição das fronteiras psíquicas presentes na perinatalidade, quando o grupo familiar intervém formando o tecido intersubjetivo na constituição da vida psíquica individual.

O aporte teórico de Correa (2003) nos ajuda a pensar a contribuição de Freud para a revivescência do narcisismo dos pais na relação com os filhos, assinalando uma continuidade na vida psíquica entre as gerações:

O vínculo mãe-bebê e o grupo familiar constituem o berço psíquico
do sujeito, constituído por uma tecelagem psíquica grupal que
atravessa outras gerações. Os processos de transmissão solicitam
um importante trabalho psíquico no qual participam mecanismos de
identificação junto a uma série de projeções-introjeções. Sua
problemática atravessa e opera sobre o recalcamento e a culpa,
envolvendo diversas categorias de interdição (Correa, 2003, p. 35).

$\mathrm{Na}$ transmissão psíquica intergeracional, o que está em jogo é fundamentalmente um trabalho matizado por ligações e transformações. O contrário se dá na transgeracional em que não foi possível haver uma modificação e os elementos são transmitidos aos descendentes em estado bruto, sem ter sido contidos, e, devido à impossibilidade de inscrição psíquica nos pais, podem ficar depositado na criança. Correa (2003, p. 36) cita: "os lutos não realizados, objetos desaparecidos sem traço e sem memória, a vergonha, as doenças e a falta".

Assim, o nascimento expõe e reatualiza questões antigas a respeito de conteúdos que não foram metabolizados pelas gerações precedentes. Pela repetição, mostram que merecem uma atenção para além da aparente e um cuidado essencial nesse momento de inícios, seja da vida de um dos membros, seja da família que recebe esse novo ser.

\footnotetext{
${ }^{48}$ MAGNANA, J. Observation d'un bébé avec Esther Bick. Journal de Psychanalyse de l'enfant, Bayard, n. 12, p.173-208, 1992.
} 
O que presenciamos nesses primeiros encontros após o nascimento foi justamente a repercussão desses impactos do nascimento na vida dessas mulheres e como os homens também foram profundamente afetados.

\section{SEGUNDO ENCONTRO APÓS O PARTO}

Nesse momento da relação mãe-bebê, incluímos no processo de elaboração dos lutos os seguintes aspectos, que serão articulados sob a ótica de dores e amores, pois para esse ponto convergem todos os outros arrolados.

\section{Dores e amores}

- reverberações do trauma

- retroalimentação libidinal e mobilidade de questões

- percepção de mudanças em si mesma e no bebê e confiança na capacidade de ser mãe

- rede de apoio

- bebê

\section{Sobre dores e amores}

O material de pesquisa contém elementos preciosos sobre os transtornos e as transformações que o papel materno e a presença do bebê ensejam na qualidade das perdas a que as mulheres ficam sujeitas no puerpério.

Esse encontro se mostrou uma espécie de inventário das perdas e, para algumas participantes, também dos ganhos com a vinda do filho. É intrigante que, ao ganhar um bebê, a mulher também sofra perdas significativas, e parece que só com a possibilidade de realmente entrar em contato com os prejuízos e elaborá-los é possível vivenciar os ganhos que essa presença também implica. 
Em outras palavras, é só no encontro com a realidade e, portanto, com as perdas e sua necessária elaboração, que se podem recuperar os ganhos, que, antes disso, eram apenas idealizados. Destarte, deve haver uma paulatina construção da relação mãe-filho ao longo do tempo, ao lado do processamento dos extravios que a maternidade comporta, para que a vivência seja de fato proveitosa.

De um modo ou de outro, todas as mulheres contam que a maternidade traz um turbilhão de emoções e que o recém-nascido exige algo de valor inestimável: a liberdade pessoal da mulher, fazendo com que muitas vezes, nesses primeiros tempos, sintam-se aprisionadas, privadas da "liberdade de ir e vir", como disse Isabela. É ela que também se refere a certa "insanidade materna" na decisão de ter um filho, talvez simbolizando a imensa distância que separa o projeto de ter um filho e sua concretização, reiterando a ruptura necessária entre o desejo de ter um filho e sua transposição para o desejo de ser mãe, com a vinda do bebê.

Encontramos em Labaki (2008, p. 274) um precioso aporte teórico: "a maternidade pouco ou quase nada comporta do desejo de engravidar, ou de ter filhos, considerado nos termos narcísicos e falocêntricos até então difundidos". E ela se realiza segundo regras diversas das da corrente narcísica:

[...] para acontecer enquanto investimento no devir e no exercício permanente de diferenciação, a maternidade leva a mulher a perder. Se, como afirma Freud (1976), ${ }^{49}$ a descendência é uma das poderosas formas de homens e mulheres buscarem satisfazer seu narcisismo frustrado infantil, a maternidade, para acontecer, solicita um esforço contrário, de desprendimento de si. Isto é, de separação de um ideal projetado no bebê que reflete as ilusões narcisistas da mãe e suas representações de filha ideal. Assim, se a gravidez mantém a simbiose de um corpo para dois e o parto faz a ruptura, então, com o nascimento, mãe e filho precisam, cada um a sua maneira, se haver com a imposição da separação e o apelo que faz para a diferença, alteridade.

Assim, o puerpério imediato é extremamente rico, como aponta a literatura, e potencialmente traumático, exigindo uma torção do desejo de engravidar e do desejo de ter filho para a difícil travessia para o desejo de maternidade, que pressupõe perdas, levando a um giro importante de perspectiva, uma vez que o investimento necessário no filho pode ser sempre vivido como excessivo, pois porta em seu cerne

49 FREUD, S. Sobre o narcisismo: uma introdução. In: Edição Standard Brasileira das Obras Psicológicas Completas de Sigmund Freud. Rio de Janeiro: Imago, 1976 [1915]. v. XIV. 
um "pedaço de si" que não só é doado à criança, mas será para sempre dela, sem retorno para a mulher. Suspeito que esse é um processo vivido ao longo da maternidade, e não só nos primeiros tempos do filho, quando se impõe o exercício permanente de diferenciação do eu materno e do eu da criança.

Acredito que o estranhamento e o traumatismo do nascimento de um filho se devam exatamente à imposição da presença do bebê na realidade e em sua absoluta dependência. Isso tem um grande impacto nos pais, que agora devem transpor o que é da ordem do desejo narcísico e transformá-lo em desejo de um outro ser, ao mesmo tempo em que o investimento na alteridade do filho deve ser para sempre.

Imagino que tal impacto seja intensamente vivido por todas, mas em algumas mulheres pode haver uma melhor negociação entre o desejo de ter filho e o da maternidade. Como bem mostrou Isabela, pode haver na relação uma retroalimentação libidinal que permita à mãe ocupar novos lugares, pois nutre seu filho com seus investimentos maciços, mas ele os retribui incrementando a relação com ela.

O fato de as mulheres perceberem que seus filhos crescem, se desenvolvem e começam a manifestar a cada dia uma resposta ao investimento materno facilita a retroalimentação libidinal, pela qual a mãe que alimenta o filho com sua libido sente que é também nutrida pela relação com ele, incrementando algo de natureza cíclica. A despeito de todo o impacto e todo o trabalho que o bebê exige nos primeiros tempos, o prazer na relação com ele parece fornecer matéria-prima fundamental para ajudar a mulher a suportar as perdas a que se vê sujeita.

Isabela parece testemunhar claramente esse aspecto. Percebendo mudanças em si própria e em seu filho, pode confiar cada dia mais na sua capacidade de cuidar e de ser mãe desse filho, e este reage a isso oferecendo-lhe seus primeiros olhares e sorrisos, tornando-a menos estrangeira como mãe e atenuando os sentimentos de perda - que não precisou negar por ter podido acolhê-los e, depois, satisfeita, compartilhá-los comigo.

Desde a primeira entrevista, o bebê de Isabela é sentido como "bonzinho", possivelmente em função de uma sintonia com sua mãe. Nessa entrevista, ela conta 
que ele já interage, incrementando sua confiança materna e favorecendo uma certa mobilidade das questões: elas são diferentes das da primeira entrevista, o que parece significar que a dupla atravessou a fase mais crítica e que a mãe vem encontrando formas de superar as dificuldades iniciais inerentes ao exercício da maternidade.

Acreditamos, com Isabela, que sua possibilidade de tomar contato e vivenciar as perdas fez com que pudesse também contar com os ganhos que the proporciona o prazer na relação com seu filho. Acredito que o suporte oferecido por sua mãe e possivelmente uma boa introjeção da figura materna, bem como a capacidade de dialogar e encontrar uma solução conjunta com o marido tenha favorecido sua possibilidade de acolher tanto as demandas do filho quanto as angústias sentidas nesses primeiros tempos com ele, na chamada "troca de pele", mutação profunda a que o psiquismo parental fica sujeito no pós-parto (Prat, 2008). Além disso, penso que Isabela pôde contar com capacidades internas de acolhimento e metabolização das angústias inerentes a algumas experiências.

Por outro lado, Gabriela ilustra o quanto para algumas mulheres pode ser problemática a travessia do desejo de engravidar e ter um filho para o de ser mãe. As perdas lhe acarretam um profundo dano, do ponto de vista narcísico; sente-se exaurida, desvitalizada, roubada pelo filho. Sua vida não Ihe pertence mais, e ela não parece contar nem com suportes de terceiros, nem com a capacidade de se retroalimentar na relação com o filho. A dor da perda de sua vida anterior parece impor-se ciclicamente também na relação com o bebê: as questões difíceis são as mesmas. As perdas são vividas como desespero atroz, uma vez que não podem ser transformadas em ganho na relação. Seu narcisismo parece encontrar dificuldades para transvasar para o filho, e ela não pode contar muito com a construção de seu papel materno, com a capacidade de ser mãe de seu filho. O que aparece é um medo profundo de ser muito importante para ele. A demanda que ele the endereça com seu olhar penetrante parece assustá-la, pois reafirma a necessidade de ela se descentrar de si mesma para acertar o tom com seu filho, o ritmo do encontro.

Com a retroalimentação libidinal também prejudicada, o filho de Érika cresce, engorda e mama direitinho, mas não parece inspirar regozijo materno. Os cuidados existem, e há uma grande preocupação em acertar, mas tudo parece destituído de 
prazer e substituído pelo que a pediatra manda fazer - Érika não consegue encontrar prazer em sua relação com o filho.

Parece ser comum entre as mulheres a dificuldade de passar do desejo de ter um filho para o de ser mãe de fato, e isso nos remete novamente ao valor idealizado da maternidade agora disseminado em nossa sociedade. De fato, não é fácil fazer essa torção do desejo, mas o que vimos é que, para algumas mulheres, isso é possível, mas, em outras, encontra obstáculos importantes, arrastando as dificuldades de encontro e sintonia com o bebê real e o exercício da maternidade também num contexto real. Nesse momento de perinatalidade, a reatualização de conteúdos transgeracionais potencialmente favoráveis para atravessar as relações incidem de forma latente nas trocas entre o bebê e seus pais.

Significativamente distinto do de Gabriela, o movimento de transição entre ter um filho e ser mãe em Vanessa parece denotar a "reviravolta materna". Quando diz que não consegue ter nem alimentação, nem sono, nem higiene adequadas, leva a pensar numa tensão sem tréguas: "dá vontade de sair correndo". Parece dizer de um desespero e um desamparo porque o projeto idealizado de engravidar e ter filho não pressupunha essa avalanche com a qual se vê confrontada: quando o bebê chora, ela chora junto; o leite, que era muito, agora é pouco. Mas há certa mobilidade, os problemas não parecem os mesmos, fazendo a mãe compreender que, apesar das dificuldades, o bebê cresce e se desenvolve; ele fundamentalmente sobrevive, o que parece ajudá-la numa paulatina desidealização de seu papel materno.

As perdas vividas por Vanessa nos remetem à questão do sistema idealização/desidealização dos pais no encontro com o bebê real. Entre os diversos autores que o afirmam, destacamos Freud (2010) e Bydlowski (2007): a criança imaginária é a depositária do desejo narcísico de imortalidade do Eu e supõe cumprir, reparar e preencher tudo. Essa criança imaginária é, por excelência, matizada por desejos narcísicos, sendo necessária para alimentar a relação dos pais primeiramente com o projeto de filho e depois com o filho que cresce no ventre materno. Entretanto, o que deve haver é uma transformação do desejo de ter filho para o desejo de ser mãe, resultando numa desidealização que os primeiros tempos de vida de um filho necessariamente impõem aos pais. Assim, o registro narcísico do 
ideal vai cedendo passo à construção do vínculo com a realidade dos cuidados e de todos os impactos decorrentes da presença desse ser.

De acordo com Bleichmar (1994), é a partir do narcisismo transvasado para o filho que surge a possibilidade da alternância geracional, sempre acossada a certa porção do que é transmitido sem transformação, caso da transgeracionalidade. É a partir do próprio narcisismo que os pais transmitem o que há de mais humano, por ceder uma porção narcísica ao filho. Além disso, o encontro com o desamparo do filho faz reativar seu próprio desamparo, o que temos visto no material analisado, como uma prova de fogo para quem se aventura nas trilhas da parentalidade.

A maternidade e a parentalidade impõem a vivência do desamparo por excelência. Carla descreve como árduos os impactos que o nascimento do bebê têm na família. Nada fica como antes: "trocaram o marido na maternidade e agora estão devolvendo aos poucos", o filho mais velho tem ciúme do mais novo, o bebê não mama direito e não dorme direito e ela própria fica resfriada. A conversa com o marido e o pedido de que ele esteja mais perto nesse momento parece tê-la ajudado. Apesar das dificuldades, por poder contar com certa mobilidade das questões, percebe os ganhos do filho: um bebê que cresce, engorda, está mais esperto e pode travar um diálogo com o olhar, retroalimentando-a. Pelo olhar, percebe que seu filho está mais vivo e, apesar das dificuldades desse que ela considera o pior momento na criação de um filho, acredita em sua capacidade de cuidar.

A possibilidade de haver mobilidade das questões e das queixas, a crença na capacidade de compreender gradativamente o bebê e lhe oferecer aquilo de que ele precisa e a retroalimentação libidinal da dupla podem favorecer o encontro e a superação de algumas das dificuldades iniciais, ou, em outras palavras, um certo reencontro com a boa mãe internalizada na mulher, ajudando-a o exercício da maternidade. As perdas e as diversas dificuldades podem fazer parte do processo quando a mulher se sente amparada pelo meio e pode paulatinamente acreditar na construção do papel materno e em sua capacidade de conter o bebê, ter prazer na relação e perceber que, mesmo com algumas dificuldades, ele cresce e se desenvolve e seu olhar fica mais vivo, retroalimentando as capacidades de sua mãe. 
Talvez não coincidentemente, os bebê das duplas cuja relação mais me preocupava - pela dificuldade dos investimentos maternos e, no caso de uma delas, também pelo vínculo desencontrado - foram os que ficaram doentes e foram internados em virtude de uma bronquiolite, logo nos primeiros dias.

Penso que isso pode sugerir um sofrimento presente no vínculo, como indica Rochette (2005): nos primeiros tempos, em virtude da permeabilidade das fronteiras entre os psiquismos dos integrantes da família, os conflitos psíquicos são difundidos na intersubjetividade, acarretando um sofrimento no vínculo. E também podemos pensar que isso se pode refletir de maneira contundente na família e mesmo perdurar em sua própria dinâmica.

Esse vértice remete à importante questão levantada por Rochette (2005) a respeito de o nascimento ser um momento propício para transbordar as capacidades de elaboração individual ou grupal e gerar algo de ordem traumática. Penso que essa questão é central para alinhar um cuidado mais eficiente não só para a criança e para os pais, mas para toda a família.

E, assim, voltamos à especificidade das depressões do pós-parto, cujas características são muitas vezes mascaradas, o que tende a prolongá-las sem o devido cuidado. Além disso, podem também se manifestar como um prolongamento do blues materno, confundindo a todos.

Conforme discutido em trabalho anterior (Folino, 2008), no pós-parto, a depressão parece realmente muito comum, mas, quando é apenas latente, exige dos profissionais que atendem a família um olhar muito aguçado, a fim de discriminar corretamente sinais preocupantes na mãe, no bebê ou na relação entre eles.

Também não se deve negligenciar o fato de os distúrbios e as dificuldades não resultarem de um único fator. É pertinente um modelo polifatorial, como indica Golse (2003b), apoiado no conceito de séries complementares proposto por Freud, que acreditava as neuroses nasciam no intercruzamento dos fatores endógenos e exógenos, o que converge para uma abordagem transdisciplinar. Compartilho da ideia de Golse (2003b, p. 19) sobre os cuidados com o bebê e a família serem na 
interface das disciplinas. O autor alerta ainda para o perigo de operarmos uma clivagem entre corpo e psique:

Os distúrbios do crescimento e da maturação psíquica da criança, mas também o desenvolvimento normal jogam exatamente na interface da parte pessoal do bebê o que ele traz consigo, seja seu equipamento neurobiológico, genético, bioquímico, mas também os efeitos do encontro com o exterior.

\section{TERCEIRO ENCONTRO APÓS O PARTO}

O terceiro encontro após o parto se mostrou uma reafirmação dos temas abordados nos outros, mas assumiu, para cada participante, certa especificidade.

- vínculo com o bebê e retroalimentação libidinal

- sobre perdas e rupturas: reverberações da chegada do bebê, desamparo, estado emocional materno e instalação de ritmos

- casal

Como vimos nos comentários às reflexões sobre o segundo encontro, a possibilidade de perceber o desenvolvimento do bebê retroalimenta os pais e estreita o vínculo. O prazer que sente na relação com o filho faz Isabela ficar ainda mais "apaixonada" por ele. A percepção de que seu filho está saudável e de que, em alguns momentos, brinca sozinho, mas, quando seus pais chegam, prefere estar com eles parece tranquilizá-la, permitindo-lhe começar a pensar em investir em outras coisas; por exemplo, pensa em voltar a fazer ginástica. E ela antecipa as mudanças que sobrevirão ao fim de sua licença maternidade. Consegue levantar e pensar nas questões que a preocupam: elas adquirem mobilidade, e ela própria não fica paralisada com elas.

O olhar é alvo dos mais intensos investimentos, seja do bebê, seja de algumas mães, como parece ser o caso de Carla e de Vanessa. Carla reconhece as necessidades do filho pelo olhar: apropria-se de seu papel materno, conhece seu filho e acredita nesse saber, por um problema relatado no encontro anterior.

Seu bebê chorava muito e ficava incomodado após as mamadas. O médico dizia que eram cólicas, e ela acreditava que não. Isso fez o médico dar mais atenção 
às queixas e investigar melhor o motivo pelo qual o bebê chorava. Descobriu um distúrbio no esvaziamento gástrico, e a medicação diminuiu o brutal desconforto do bebê, que atingia toda a família.

Há prazer no encontro entre Carla e esse novo filho, mas também surpresas. Ele traz outros impactos e outras intensidades: come mais, chora mais e ri mais do que o filho mais velho, remetendo-a a um novo aprendizado: o de ser mãe desse bebê em particular.

Acreditar em sua capacidade de ser mãe permitiu a Carla se apropriar de um saber sobre seu filho, incrementado por sua experiência anterior de maternidade, mas também pela capacidade de se vincular a ele apesar de todas as dificuldades. Seu depoimento remeta ao fato de que alguns médicos não ouvem realmente as mães, e sua escuta pré-formatada dificulta o diagnóstico e prolonga um sofrimento que poderia ser atenuado com medidas simples, como nesse caso.

Não é apenas a primiparidade que impacta e reverbera nas vivências do puerpério, mas sobretudo a presença de um filho, que, em sua particularidade e por projeções maternas ou paternas, pode atingir seus pais de forma diferente da de um outro filho. Os achados da pesquisa sugerem que, com o primeiro filho, a mulher precisa abrir em seu psiquismo as trilhas do descentramento psíquico imposto, mas isso não a isenta de sofrer novas mudanças com a vinda de um outro bebê, pois cada filho traz aos pais algo único.

Vanessa, por seu turno, fala de um olhar que comunica mas que pode ter características persecutórias - algo entre a paixão e a raiva. O vínculo cresce e a relação caminha, mas parece muito tingida pelas cores das projeções maternas. Por exemplo, o filho tem que entender que ela não tem mais leite em excesso como antes. Está-se construindo uma relação com o bebê real, mas ainda muito atravessada por projeções maternas. Suas falas apontam um desejo materno de não se separar de seu bebê, um filho que é um "grude"; ele não fica bem a não ser em seu colo e chora quando é posto em qualquer outro lugar. A participante brinca dizendo ao filho que vai colocar um velcro em si e nele.

Isso indica como, para algumas mães, é penosa a necessidade de uma gradativa separação e individuação do bebê. Parece ter que se dar em dois níveis: 
do bebê em relação à mãe e dela em relação ao bebê. $O$ desejo materno de ficar grudada, negando de certa forma a separação de corpos imposta pelo parto, talvez diga de certa dificuldade de fazer o luto por uma parte de si mesma - o bebê ideal que viveu em seu ventre e em seu psiquismo. A duras penas, Vanessa tenta elaborar uma perda narcísica importante, metaforizando a dificuldade de se separar do ideal narcísico, e ainda a perda da imagem de uma mãe plena de leite que amamentaria seu filho exclusivamente no peito.

Talvez a dificuldade de Vanessa amamentar seu filho reflita, como dito antes, o impacto de ter que fazer viver um filho, mas também pode estar a serviço da exigência de se separar de seu bebê. Ela conta como a rotina e o ritmo dos cuidados com o bebê se dão a partir de um descentramento psíquico: agora, ela não está mais sozinha e precisa considerar as reais necessidades do bebê, algo que deve aprender na relação real com ele, pois não estava dado desde o início. Para Vanessa, o bebê passa a ser um estranho - diferente do filho idealizado, que era seu "velho conhecido" - e agora demanda ser conhecido de fato. Ela mostra como as mães precisam ser apoiadas nessa tarefa de ir conhecendo seu filho na relação diária com ele, concomitante à instalação de um ritmo particular a cada dupla; algumas têm mais facilidade e outras, como Vanessa, precisam de mais tempo para fazer a torção necessária de desidealização tanto do bebê quanto de si mesma como mãe.

Gabriela, em outro vértice, vive de outro modo o desenvolvimento do bebê e a instalação de uma rotina para ela e para o filho. Não nega o desenvolvimento da criança, mas esta não parece ser suficientemente competente aos olhos de sua mãe. Ela quer que o filho cresça depressa, vivendo os cuidados e esses primeiros tempos de forma terrífica e ameaçadora. Suas falas reiteram continuamente 0 quanto se sente exaurida e roubada pelo bebê, mantendo na relação um tom de retroalimentação negativa.

A possibilidade da gradativa instalação de uma rotina para a dupla facilita 0 vínculo e é também um importante organizador, diminuindo a angústia materna, como aconteceu com Isabela, Carla e Vanessa. No caso de Gabriela, as coisas parecem diferentes: a rotina não se estabelece a partir do que ela percebe como necessidade do filho, mas como uma tentativa de livrá-la da angústia. 
Isabela, mais uma vez, fala de uma construção mais harmônica da relação, pela via do prazer, a partir de experimentações do que pode ser bom para o filho. Conta que, junto com ele, instala gradativamente uma rotina viva de cuidados, e não puramente automática e réplica daquilo que leu ou ouviu da pediatra. Érika experimenta de forma menos viva e prazerosa a relação com o filho, que habita seu discurso de maneira empobrecida e só quando esteve doente. Parece haver uma forma mecânica de cuidados: a "cumpridora de ordens" se revela sobrecarregada, extremamente cansada e tentando amortecer os impactos a que se vê sujeita em sua vida nesse momento.

Todas as mães têm encontros e desencontros com seu bebê - não se acerta sempre. Mas, a partir desta pesquisa, vê-se que instalar uma rotina, um ritmo alinhado às necessidades que a mãe percebe na criança, pelos sinais que ela vai dando, aumenta a possibilidade de haver encontros e de eles serem mais prazerosos. Acerta-se mais quando se conhece o filho, e uma rotina concorre para isso.

Além de ser um momento de passagem, o início da vida pode remeter a uma vivência disforme, de caos e de desamparo. Vimos que o estabelecimento de uma rotina é capaz de ajudar a dar um contorno a essa situação disforme do começo de vida do bebê, e me parece que isso vale também para a mãe e a família.

Pudemos ver que uma rotina viva e a capacidade da mãe de se conectar sensivelmente ao filho concorrem para que a dupla encontre um lugar de abrandamento do desamparo materno, como testemunha Isabela.

Carla também corrobora essa constatação ao contar que o filho responde a seus cuidados, da intimidade e do ritmo do encontro com ela. As sutilezas são levadas em conta, concorrendo para o bem-estar do bebê e para a boa relação da mãe com ele. Com a melhora dos sintomas do retardo do esvaziamento gástrico no bebê e a normalização do sono da mãe, acertou-se o compasso entre eles. $O$ fato de ter deixado de amamentar - algo que the exigia muito e a debilitava - e a retomada de atividades com o filho mais velho também concorreram para uma espécie de acerto no ritmo.

As questões apontadas convergem para o tema do ritmo e levam a pensar que, no início da vida, ele é sumamente importante não só para o bebê, mas para a 
família. A partir da análise do material, suponho que o nascimento de um bebê quebra o ritmo anterior estabelecido e atinge a mãe e todos da família.

A esse respeito, Victor Guerra (2010, p. 280) sublinha que o ritmo está presente desde a sonoridade da língua materna, ajudando a formar "parte do itinerário existencial do ser humano". Assim, podemos pensar que desde o ventre 0 bebê escuta a música contida na fala da mãe. $O$ autor também sugere que o ritmo estaria ligado e significaria:

[...] reiteração de uma experiência de forma cíclica e com certo grau de previsibilidade [...] organização temporal da experiência [...] [uma das] primeiras formas de inscrição da continuidade psíquica, um núcleo primário de identidade (identidade rítmica). [...] A vitalidade rítmica que estabeleceria essa indicação primária de "estar com" outro ser humano estabelece, além disso, uma forma primária de identidade no interior do bebê (Guerra, 2010, p. 281/282).

Esses três vértices do ritmo nos levam a pensar que a experiência dos cuidados, a alternância da presença-ausência materna e o respeito às reais necessidades do bebê instalariam um núcleo primário de identidade rítmica (Guerra, 2010, p. 282).

Por outro lado, a perda de ritmo sentida pelas mulheres indica o quão violenta ela pode ser, como se tratasse de algo ligado à própria identidade. Perde-se muito quando se perde o próprio ritmo - é isso que parece indicar o sofrimento dessas mulheres. E, incluída no exercício do papel materno, essa perda é sentida mais duramente, pois atinge algo basal na vivência da mulher.

Assim, todos esses elementos apontam para a necessidade de harmonização dos ritmos entre o bebê e os pais, e o atropelo do ritmo destes no nascimento de um filho desencadeia o que temos visto no material analisado: uma importante desorganização da antiga identidade da mulher, do homem e do casal, sem falar em quando há outros filhos.

Se, em algum tempo, o casal for capaz de corrigir a rota e acertar os passos dessa dança com o bebê, estabelece-se uma parceria fundamental para o bom andamento das relações da família, depois da necessária desestabilização com a chegada de um novo membro. Essa chegada pode, inclusive, ser entendida como uma possibilidade de encontrarem um novo ritmo. 
Penso que Isabela e Carla atestam que encontrar um arranjo original e uma outra harmonia com o marido e imprimir à vida um novo ritmo coloca a possibilidade de haver uma nova identidade para essa família e para cada um de seu membros. Pela possibilidade de se colocar no lugar do outro sem menosprezar suas próprias necessidades, podem juntos encontrar um caminho interessante.

A perda de ritmo da mãe, do pai e, quando há, também do filho mais velho tem um grande impacto na questão das identidades, o que explica a violência com que ela é sentida. É como se se perdesse o chão, mesmo que seja temporariamente e que haja recursos atenuantes individuais e da família.

A "troca de pele", para usar as palavras de Prat (2008), impõe uma séria questão para a saúde pública: como podemos ajudar crianças e bebês se não nos dispomos a prevenir e cuidar na família da desorganização inerente a esses primeiros tempos? Vejo pediatras muito preocupados em ajudar seus pequenos pacientes sem ter um olhar mais amplo para essas esperadas faltas de harmonização inicial quando da chegada de um novo membro à família.

Mas não acredito que só os pediatras devem estar implicados nessa questão, e sim todos os profissionais envolvidos nos cuidados com a gestante, a puérpera, a família e a criança nos primeiros tempos de vida. Sabemos que, muitas vezes, o que não se previne com uma assistência ampliada e cuidadosa pode prolongar e aumentar sofrimentos e limitações importantes.

Cada vez mais observamos avanços na pesquisa e na assistência em vários vértices dos cuidados com as pessoas, mas o que parece ainda faltar é alinhar os conhecimentos das disciplinas envolvidas, a fim de oferecermos um cuidado ampliado e de qualidade.

Os achados desta pesquisa mostram que, de modo geral, as mães passam por períodos de extrema intensidade e de significativas mudanças, e reagem a isso não só por meio da tristeza, como foi visto em Isabela, Carla e Vanessa, mas com todas as alterações e adaptações resultantes desse grande impacto. Isso pode suscitar reações ansiosas e, eventualmente, o desenvolvimento de quadros depressivos latentes.

Apesar de ter sentido que algumas mulheres de nossa amostra se beneficiariam de ajuda terapêutica nesse momento, em virtude de certos sinais que 
apareceram nas entrevistas, não encontrei nem espaço e nem demanda para um encaminhamento mais específico. Penso em procurá-las para saber como estão e como caminha a relação e se gostariam de conversar a respeito.

Assim, mesmo uma gestação desejada e um bebê nascido a termo e sem anomalias, como foi o caso das mulheres de nossa amostra, o nascimento de um bebê na família implica um extremo desamparo inicial. 


\section{Considerações finais}

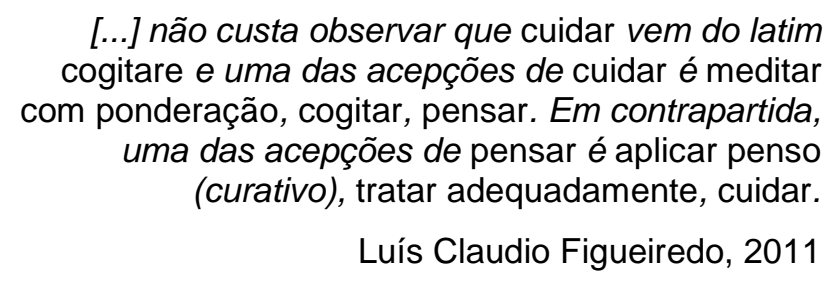

O que uma tese pode ensinar àquele que se the dedica intensamente? Costumo pensar que nos aplicamos a um trabalho como esse por diversas razões, mas fundamentalmente ele é disparado por uma questão pela qual o pesquisador se vê interpelado, e é ela que norteia e marca sua trilha na pesquisa.

Assim, o envolvimento com a questão de pesquisa aponta um caminho para o pesquisador. No caso desta tese, foi um caminho de atenção às sutilezas exigidas pela perinatalidade e pela construção da parentalidade - fundamentalmente, um trabalho marcado pela delicadeza implicada no encontro com o universo dos cuidados e dos impactos do nascimento de um bebê na família. Mais especificamente, é da elaboração das dores e dos amores nesse percurso que nasce a possibilidade da genuína parentalidade. $\mathrm{E}$ a falta ou a insuficiência dessa elaboração pode acabar resultando num quadro depressivo mais sério, como acontece com muitas mulheres.

Ainda sobre o percurso da pesquisa, a escrita é uma tentativa de dar significado ao impacto e às vivências sentidas ao longo do processo de gestar a tese e, pela possibilidade de pensá-las, transformar sua complexidade inerente em pensamento e talvez numa contribuição efetiva a esse campo do saber.

Acredito que a pesquisa tem interface com a assistência: não se pesquisa academicamente apenas para satisfazer a curiosidade e o desejo do pesquisador de saber mais - embora isso dê à pesquisa um caráter vivo e pulsante. Para enriquecer o campo do fenômeno estudado, a pesquisa deve proceder a um giro de perspectiva, no sentido de afinar seus instrumentos para que os achados se convertam em subsídios para pensarmos de outra forma a assistência oferecida às pessoas. Este é agora meu desejo maior. 
Assim, depois da difícil tentativa de condensar os achados e as reflexões que me foram possíveis, destaco os pontos que me pareceram mais relevantes.

O estudo mostrou a importância de se valorizarem os fenômenos do gestar e do cuidar e de dar-Ihes a devida atenção não a partir de medidas controladoras ou normatizadoras, mas no que elas têm de mais especifico: a hipersensibilidade materna e o impacto do nascimento naqueles que geram e cuidam de um bebê em seus primeiros tempos.

Desde a confirmação da gravidez, mesmo planejada, há um susto, anúncio do que estará por vir. Esse susto já anuncia uma transição, o impacto que sobrevém quando o projeto de um filho aponta para a realidade da experiência.

$\mathrm{Na}$ antecipação do bebê e do papel materno, em certa medida esperada e desejável, podemos ter indícios de como se processa essa transição, em curso desde a gestação. Trata-se aí de como a mãe pode ir gradualmente desinvestindo de sua vida anterior para passar a investir em seu bebê e em seu lugar materno.

Há aí um importante achado da pesquisa: a regressão típica desse período pode ser experimentada como brutal por algumas mulheres, por sua dificuldade de desinvestir da vida anterior para investir na nova que se anuncia. Isso se pode apresentar como uma resistência para regredir e, consequentemente, para entrar nesse estado mais sensível, desde a época da gravidez, prejudicando a instalação da capacidade do que Winnicott (2000a) denominou preocupação materna primária. Essa dificuldade pode também inibir a saudável depressividade que permitiria dar um melhor contorno e elaborar as perdas e os impactos a que a mulher se vê sujeita.

Por outro lado, o investimento num bebê e num papel materno extremamente idealizados pode indicar uma dificuldade de elaboração psíquica no período do pós-parto, com a chegada do bebê real.

Em relação ao momento do parto, nossa pesquisa mostrou que ele é transbordante por excelência, pois invade a mulher e lhe exige criar um ambiente que possa acolher as angústias inerentes ao evento, que, uma vez mais, podem ser significadas muitas vezes como terríficas e/ou ameaçadoras. 
Apesar de nosso estudo ter partido da observação das mulheres e da relação que estabelecem com seu filho (desde a gestação), notamos que os impactos não são sentidos só pela mãe. As fronteiras psíquicas são lábeis, e os conflitos e as angústias se refletem em todo o ambiente familiar e podem talvez se estender ao longo da vida de todos os envolvidos.

Assim, é fundamental ampliar ou abrir um outro campo de cuidados, contra o risco de fazer julgamentos e favorecer medidas culpabilizadoras da mãe ou da família, nesse momento ou até mais tarde, na vida. Sabemos o quanto as famílias são acusadas de ser responsáveis por supostos desvios das crianças, por exemplo, na idade escolar ou na adolescência.

Com uma compreensão mais ampla das questões envolvidas no impacto da vinda de um novo ser na vida de quem o acolhe, podemos ultrapassar certo reducionismo na abordagem desses fenômenos e oferecer um ambiente mais propício tanto para a criança que chega quanto para quem a acolhe, com a possibilidade de oferecer um cuidado mais alinhado às reais necessidades da família.

O impacto decorre de uma particularidade do psiquismo de quem gesta e dá à luz: pelo afrouxamento da repressão, a pessoa fica hipersensível e seu psiquismo, transparente, deixando emergir conteúdos que normalmente não estão acessíveis à consciência, o que pode deflagrar estados extremamente difíceis e/ou delicados nesse momento de vida da mulher.

Outra exigência desse momento é que a mãe abandone algumas crenças idealizadas para se aperceber do que Ihe traz a realidade. Dito de outro modo, ela deve lidar com um bebê que, apesar de ter sido antecipado como alguém que tem várias capacidades - algumas das quais ele pode ter realmente -, precisa ser ajudado a viver.

Destarte, o nascimento se revela em sua face mais difícil - a de transbordamento e de certa impossibilidade de conter e metabolizar facilmente tamanho impacto. A pesquisa revelou que a dificuldade de se metabolizarem essas tensões que sobrevêm ao nascimento pode concorrer para a instalação de quadros difíceis no puerpério. 
$\mathrm{E}$, mais do que isso, esses estados caóticos podem se prolongar, se a família não conseguir sozinha digerir esses profundos excessos a que fica sujeita, o que se refletirá em cada um de seus membros de maneira particular.

O estudo mostrou que é fundamental acolher o que se mostrou uma demanda latente de cuidados no tempo da gestação e no puerpério. Por um lado, sofremos hoje a escassez de suporte social para esses tempos, e, por outro, a pesquisa reiterou a necessidade desse suporte, pois tudo parece sair do lugar: abalam-se as identidades e se perdem os ritmos; tudo transborda e exige dos envolvidos que contenham e transformem as dores sentidas. E tudo isso fica muito mais difícil sem o devido suporte, que a cultura parece negar reiteradamente.

Nesses termos, é fundamental pensarmos e trabalharmos no sentido de construir programas preventivos de saúde pública que contemplem a oferta de cuidado ampliado de qualidade, ouvindo e acolhendo a mulher e a família nos primeiros tempos de um bebê que nasce.

A pesquisa mostrou ainda que, quando as dores puderam ser experimentadas e compartilhadas - comigo, por exemplo -, abriu-se a possibilidade de contê-las. Mesmo que não fosse o objetivo primeiro da tese intervir nos fenômenos, o simples fato de eu estar na cena e me mostrar interessada, atenta e disponível nesse momento difícil parece ter feito uma real diferença para algumas mulheres. Talvez meu genuíno interesse por elas, suas dores e também seus amores tenha favorecido uma espécie de contorno para esse momento de transição que representam a gestação e os primeiros dias do bebê na família.

Por isso, penso que se fazem necessárias uma conscientização e uma permanente atualização dos profissionais ligados ao atendimento à família, que, num trabalho conjunto e forçosamente interdisciplinar, desmistifiquem a crença de que a tarefa da maternidade é "natural" e se disponham a prestar à mãe - e à família do bebê - a ajuda qualificada de que elas de fato precisam.

Vimos, ao longo do estudo, que há um necessário trabalho de processamento das dores vividas nesse período e que, para além das razões hormonais a que comumente se atribui o blues, existem lutos a ser elaborados que evocam sentimentos de dor e de tristeza, ao lado de todas as alegrias associadas à chegada 
de um novo bebê. Admitir tal sentido a essa experiência implica considerá-la também como um pedido latente, uma demanda de cuidado e sustentação nesse momento delicado.

Entretanto, cumpre observar que, nessa administração dos sofrimentos e das dores que devemos ajudar a conter, sustentar e revestir de sentido, não podemos cair no polo oposto, qual seja, o de sua patologização.

Vimos que, apesar de reverberar em todos os envolvidos, a depressão puerperal é muitas vezes latente, e seus sinais podem ser tomados por uma manifestação comum, por exemplo, do grande cansaço que as pessoas sentem nesses primeiros tempos da vida do bebê.

São as sutilezas da relação estabelecida com a criança que nos informam e dão elementos para acompanhar como ela caminha. Uma relação tingida por certo automatismo dos cuidados merece atenção, e a possibilidade de a mãe ir conhecendo seu filho na experiência desses cuidados diários e estabelecendo ritmos alinhados às reais necessidades do bebê se mostrou um indício interessante da qualidade do vínculo. Além disso, ela própria conseguir, depois de um tempo, confiar em sua capacidade de cuidar de seu bebê também indica uma acomodação satisfatória desses primeiros tempos.

Penso que só se pode descartar a possibilidade de um estado mais sensível, característico da acomodação emocional que o blues materno adquire, para um quadro mais sério de depressão, mesmo latente, depois de acompanhar atentamente a dupla mãe-bebê durante algum tempo. Ou seja, não se pode fazê-lo numa consulta rápida e sem a devida atenção.

Assim, a ajuda de um acompanhante pode ser fundamental não só como um apoio necessário nesses tempos, como vimos, mas para obter mais elementos sobre como caminha a relação entre a mãe e o filho.

O estudo mostrou que a tristeza materna demanda uma escuta atenta e que essa compreensão orientará o cuidado e o apoio à família nesses tempos.

Também devemos estar atentos à dupla mãe-bebê a fim de prevenir transtornos que podem se instalar em um ou outro ou na relação entre eles. Além 
disso, há que considerar os efeitos no casal e na família, que se podem refletir em desarmonia e, prolongados, ter consequências deletérias.

Acresce-se que olhar, escuta e atenção permitem identificar sinais de que algo não vai bem e, assim, acusar dificuldades específicas da família e propor um trabalho terapêutico adequado.

Isto tudo posto, a titulo de conclusão, acredito que o trabalho de parentalidade é o trabalho de assimilação e elaboração das vivências trazidas pelo encontro com o bebê real e a maternidade e a paternidade reais, que implica processar as perdas e os impactos na transformação do desejo de ter um filho para o desejo de ser mãe desse filho, bem como enfrentar o desamparo e os conflitos decorrentes da permeabilidade das fronteiras psíquicas nesse momento.

Trata-se de um movimento que pode transformar a experiência e levar à vivência dos amores, fruto não de idealizações, mas da possibilidade do encontro de uma mãe real, apenas suficientemente boa - com um bebê também real e demandante.

Nesse ponto, a teoria geral do cuidar, de Luís Claudio Figueiredo (2009) dá um contorno e sintetiza o que nos ensinou o trabalho da tese: a importância da tarefa ética nos cuidados que se devem dispensar à família nos primeiros tempos do bebê:

Fazer sentido implica estabelecer ligações, dar forma, sequência e inteligibilidade aos acontecimentos que ao longo de uma vida evocam e provocam o retorno às experiências da loucura e da turbulência emocional. Em outras palavras: fazer sentido equivale a constituir para o sujeito uma experiência integrada, uma experiência de integração. Tais experiências não se constituem se não puderem ser primeiramente exercidas, ensinadas e facilitadas pelos cuidados de que somos alvo. [...] consideremos o "fazer sentido" em oposição às falhas, excessos e faltas traumáticas com que a vida inevitavelmente nos desafia (Figueiredo, L. C., 2009, p. 134).

E também parece nos favorecer uma atribuição de sentido alinhada ao que acredito ter sido minha experiência de pesquisa:

Muitas vezes, cuidar é, basicamente, ser capaz de prestar atenção e reconhecer o objeto dos cuidados no que ele tem de próprio e 
singular, dando disso testemunho e, se possível, levando de volta ao sujeito sua própria imagem (Figueiredo, L. V., 2009, p. 138).

Por último, o mergulho nos ritmos do blues materno me fez compreender que, apesar de ser tratado como benigno, quase sem importância - pois, não tendo uma característica patológica, não desperta muito interesse -, revelou-o de importância ímpar, porque mostrou que ele demanda um trabalho rico de elaboração psíquica da parentalidade.

E, como vimos, não se reduz a desequilíbrios hormonais, mas deriva de um total remanejamento psíquico que é deflagrado pelo nascimento de um filho. Dessa forma, deve ser entendido como expressão de um sofrimento, fruto de um transbordamento, além de ser uma demanda latente de cuidado a que se deve especial atenção. 


\section{REFERÊNCIAS}

ALVAREZ, A. Companhia viva: psicoterapia psicanalítica com crianças autistas, borderline, carentes e maltratadas. Trad. Marta Adriana Veríssimo Veronese. Porto Alegre: Artes Médicas Sul, 1994.

ALVES, A. P. A. Do blues ao movimento pelos direitos civis: o surgimento da "black music" nos Estados Unidos. Revista de História, v. 3, n. 1, p. 50-70, 2011. Disponível em: <http://www.revistahistoria.ufba.br/2011_1/a04.pdf>. Acesso em: 3 jan. 2014.

ARAGÃO, R. O. Narcisismo materno e criação do espaço psíquico para o bebê. In: Tornar-se mãe de seu próprio filho. Curitiba: Honoris Causa, 2011.

AULAGNIER, P. Nascimento de um corpo, origem de uma história. Revista Latinoamericana de Psicopatologia Fundamental, ano II, n. 3, p. 9-45, 1999.

. Um intérprete em busca de sentido. Trad. Regina Steffen. São Paulo: Escuta, 1990.

BENSOUSSAN, P. Le baby-blues n'existe pas, 2013. Disponível em:

<www.maman-blues.org/rencont/bensoussan.htm>. Acesso em: 26 dez. 2013.

BLEGER, J. Temas de psicologia: entrevistas e grupos. São Paulo: Martins Fontes, 1985.

BLEICHMAR, S. A fundação do inconsciente: destino de pulsão, destino do sujeito. Trad. Kênia Ballvé Behr. Porto Alegre: Artes Médicas Sul, 1994.

BOUKOBZA, C. O desamparo parental perante a chegada do bebê. In: BERNARDINO, L. M. F.; ROHENKOHL, C. M. F. (Orgs.). O bebê e a modernidade: abordagens teórico-clínicas. São Paulo: Casa do Psicólogo, 2002.

BOWLBY, J. Formação e rompimento dos laços afetivos. 4. ed. São Paulo: Martins Fontes, 2006.

BRAZELTON, T. B.; CRAMER, B. G. As primeiras relações. Trad. Marcelo Brandão Cipolla. São Paulo: Martins Fontes, 1992.

BYDLOWSKI, M. Psychopathologie périnatale: du "blues" à la dépression maternelle postnatale, 2013. Disponível em: <www.mamanblues.org/rencont/bydlowski3.htm>. Acesso em; 26 dez. 2013.

. La deuda de vida: itinerario psicoanalítico da la maternidad. Traducción Irene Marinas y Pablo Marinas. Madrid: Biblioteca Nueva, 2007.

- O olhar interior da mulher grávida: transparência psíquica e representação do objeto interno. In: CORRÊA FILHO. L.; CORRÊA, M. E. G.; FRANÇA, P. S. 
(Orgs.) Novos olhares sobre a gestação e a criança até os 3 anos: saúde perinatal, educação e desenvolvimento do bebê. Brasília: LGE, 2002.

CECARELLI, P. R. A patologização da normalidade. Estudos de Psicanálise. Aracaju, n. 33, p. 125-136, jul. 2010.

COELHO JUNIOR, N. E.; FIGUEIREDO, L. C. Figuras da intersubjetividade na constituição subjetiva: dimensões da alteridade. In: COELHO JUNIOR, N.; SALEM, P.; KLAUTAU, P. (Orgs.) Dimensões da intersubjetividade. São Paulo: Escuta/Fapesp, 2012. p. 19-35.

CORREA, O. B. R. Transmissão psíquica entre as gerações. Psicologia USP, v. 14, n. 3, p. 35-45, 2000.

CRUZ, E. B. S.; SIMÕES, G. L.; FAISAL-CURY, A. Rastreamento da depressão pós-parto em mulheres atendidas pelo Programa de Saúde da Família. Revista Brasileira de Ginecologia e Obstetrícia, v. 27, n. 4, p. 181-8, 2005.

CYMROT, P. Elaboração psicanalítica: teoria e clinica psicanalítica. São Paulo: Escuta, 1997.

DAYAN, J. Les depressions périnatales: evaluer et traiter. Paris: Elsevier Masson, 2008.

. Post-partum blues. In: DAYAN, J.; ANDRO, G.; DUGNAT, M. (Orgs.).

Psychopatologie de la perinatalité. Paris: Masson, 1999. p. 52-66.

DEBRAY, R. Bebês: mães em revolta. Trad. Leda Mariza Vieira Fischer. Porto Alegre: Artes Médicas, 1988.

DOLTO, F. No jogo do desejo: ensaios clínicos. São Paulo: Ática, 1996.

DROSSART, F. Résurgences archaïques chez la mere en période périnatale. Topique, v. 2, n. 87, p. 207-214, 2004.

FAISAL-CURY, A. et al. Maternity "Blues": Prevalence and Risk Factors. The Spanish Journal of Psychology, v. 11, n. 2, p. 593-599, 2008.

FELICIANO, D. S. Para além do seio: uma proposta de intervenção psicanalítica pais-bebê, a partir da escuta dos sentidos ocultos nas dificuldades de amamentação, como auxiliar do desenvolvimento. Tese (Doutorado em Psicologia Escolar e do Desenvolvimento Humano) - Instituto de Psicologia, Universidade de São Paulo, São Paulo, 2009.

FELICIANO, D. S. et al. Método Canguru como resgate do vínculo da mãe com o bebê prematuro. In: GUELLER, A. S.; DITTIMAR, M. C. V. M. (Orgs.).

Psicanálise com crianças na contemporaneidade: extensões da clínica. São Paulo: Dimensão, 2007.

FIGUEIREDO, B. Vinculação maternal: contributo para a compreensão das dimensões envolvidas no processo inicial de vinculação da mãe ao bebê. 
International. Journal of Clinical and Health Psychology, v. 3, n. 3, p. 521539, 2003.

FIGUEIREDO, L. C. Cuidado e saúde: uma visão integrada. Alter - Revista de Estudos Psicanalíticos, v. 29, n. 2, p. 11-29, 2011.

. A metapsicologia do cuidado. In: . As diversas faces do cuidar: novos ensaios de psicanálise contemporânea. São Paulo: Escuta, 2009.

; MINERBO, M. Pesquisa em psicanálise: algumas ideias e um exemplo. Jornal de Psicanálise, São Paulo, v. 39, n. 70, p. 257-278, jun. 2006.

FOLINO, C. S. G. Encontro entre a psicanálise e a pediatria: impactos da depressão puerperal para o desenvolvimento da relação mãe-bebê e do psiquismo infantil. Dissertação (Mestrado em Psicologia Escolar e do Desenvolvimento Humano) - Instituto de Psicologia, Universidade de São Paulo, São Paulo, 2008.

FONSECA, V. R. J. R. M.; SILVA, G. A.; OTTA, E. Relação entre depressão pós-parto e disponibilidade emocional materna. Cadernos de Saúde Pública, Rio de Janeiro, v. 26, n. 4, p. 738-746, abr. 2010.

FREUD, S. Introdução ao narcisismo: ensaios de metapsicologia e outros textos. Sigmund Freud. Trad. Paulo César de Souza. São Paulo: Companhia das Letras, 2010a [1914-1916].

. Luto e melancolia. In: Introdução ao narcisismo: ensaios de metapsicologia e outros textos (1914-1916). Trad. e notas Paulo César de Souza. São Paulo: Companhia das Letras, 2010b [1917(1915)].

. Luto e melancolia. Trad. Marilene Carone. Revista Novos Estudos, n. 32, mar. 1992 [1917].

GENNEP, A. V. Os ritos de passagem: estudo sistemático dos ritos da porta e da soleira, da hospitalidade, da adoção, gravidez e parto, nascimento infância, puberdade, iniciação, coroação, noivado, casamento, funerais, estações, etc. 3. ed. Petrópolis: Vozes, 2011[1909].

GOLSE, B. Será que existe para a criança uma ligação entre depressão e hospitalização? In: GILLE, M. L. (Org.). Boi da cara preta: crianças no hospital. Trad. Helena Lemos. Salvador: EDUFBA/Ágalma, 2003a.

. Sobre a psicoterapia pais-bebê: narratividade, filiação e transmissão. Dirigida por Claudia Mascarenhas Fernandes Rohenkohl. Trad. Inês Catão, Maria Auxiliadora Fernandes, Júlia Castilho, Regina Aragão. São Paulo: Casa do Psicólogo, 2003b. (Coleção Primeira Infância.)

GREEN, A. A mãe morta. In: Narcisismo de vida, narcisismo de morte. São Paulo: Escuta, 1988. 
GUERRA, V. O ritmo na vida psíquica: entre perda e re-encontro. In: ZORNIG, S. M, A.-J.; ARAGÃO, R. O. (Orgs.). Nascimento: antes e depois, cuidados em rede. Curitiba: Honoris Causa, 2010.

HENSHAW, C. Mood disturbance in the early puerperium: a review. Archives of Women's Mental Health, v. 6, suppl. 2, p. 33-42, 2003.

HERRMANN, F. Pesquisa psicanalítica. Ciência e Cultura, São Paulo, v. 56, n. 4, out./dez. 2004.

HINSHELWOOD, R. D. Dicionário do pensamento kleiniano. Trad. José Octávio de Aguiar Abreu. Porto Alegre: Artes Médicas, 1992.

ILES, S.; GATH, D.; KENNERLEY, H. Maternity blues. II. A comparison between post-operative women and post-natal women. The British Journal of

Psychiatry, London: The Royal College of Psychiatrics, n. 155, p. 363-366, Sep. 1989.

JOUPPE, J. À propos du post-partum blues. Annales Médico-psychologiques. Revue Psychiatrique, v. 165, n. 10, p. 749-767, dez. 2007.

KENNERLEY, H.; GATH, D. Maternity blues. I. Detection and measurement by questionnaire. The British Journal of Psychiatry, London: The Royal College of Psychiatrics, n. 155, p. 356-362, Sep. 1989.

KLEIN, M. Amor, culpa e reparação e outros trabalhos (1921-1945). Trad. André Cardoso. Rio de Janeiro: Imago, 1996.

KONRADT, C. E. et al. Depressão pós-parto e percepção de suporte social durante a gestação. Revista de Psiquiatria do Rio Grande do Sul, Porto Alegre, v. 33, n. 2, 2011.

KREISLER, Leon. A nova criança da desordem psicossomática. Trad. Claudia Berliner. São Paulo: Casa do Psicólogo, 1999.

LABAKI, M. E. P. Ter filhos é o mesmo que ser mãe? In: ALONSO, S. L.; BREYTON, D. M.; ALBUQUERQUE, H. M. F. M. (Orgs.). Interlocuções sobre o feminino na clínica, na teoria, na cultura. São Paulo: Escuta/Instituto Sedes Sapientiae, 2008. p. 273-284.

LANGER, M. Maternidade e sexo. Porto Alegre: Artes Médicas, 1986.

LAPLANCHE, J.; PONTALIS, J. B. Vocabulário da Psicanálise. São Paulo: Martins Fontes, 1986.

LEÃO, M. R. C. et al. Reflexões sobre o excesso de cesarianas no Brasil e a autonomia da mulher. Ciência \& Saúde Coletiva, v. 18, n. 8, p. 2395-2400, 2013.

LEBOVICI, S.; SOLIS-PONTON, L.; BARRIGUETTE, J. A. A árvore da vida ou a empatia metaforizante, o enactment. In: SILVA, M. C. P. (Org.); SOLISPONTON, L. (Dir.). Ser pai, ser mãe - parentalidade: um desafio para o 
terceiro milênio. Uma homenagem internacional a Serge Lebovici. São Paulo: Casa do Psicólogo, 2004. p. 41-45.

LONGMAN DICTIONARY OF CONTEMPORARY ENGLISH. Longman Group Limited, Harlow and London, 1978.

MARTINET, S. As depressões psiquiátricas do pós-parto. In: ;BAYLE, F.

Perturbações da parentalidade. Lisboa: Climepsi, 2008. p. 199-207.

MAZET, P.; STOLERU, S. Manual de psicopatologia do recém-nascido. Porto Alegre: Artes Médicas,1990.

MEZAN, R. Pesquisa em psicanálise: algumas reflexões. Jornal de Psicanálise, São Paulo, v. 39, n. 70, p. 227-241, jun. 2006.

MISSONIER, S. O início da parentalidade, tornar-se mãe, tornar-se pai. As interações dos pais e da criança antes do nascimento. In: SILVA, M. C. P. (Org.); SOLIS-PONTON, L. (Dir.). Ser pai, ser mãe - parentalidade: um desafio para o terceiro milênio. Uma homenagem internacional a Serge Lebovici. São Paulo: Casa do Psicólogo, 2004. p. 115-122.

MONTEIRO, D. S. F. A amamentação e seus enredamentos psíquicos. Dissertação (Mestrado em Psicologia Clínica) - Instituto de Psicologia, Universidade de São Paulo, São Paulo, 2003.

MORO, M. R. Os ingredientes da parentalidade. Revista Latinoamericana de Psicopatologia Fundamental, v. 8, n. 2, p. 258-273, 2005.

NAFFAH NETO, A. A pesquisa psicanalítica. Jornal de Psicanálise, São Paulo, v. 39, n. 70, p. 279-288, jun. 2006.

OCAMPO, M. L. S. et al. O processo psicodiagnóstico e as técnicas projetivas. Trad. Miriam Felzenszwalb. São Paulo: Martins Fontes, 1986.

O'HARA, M. W. The nature of postpartum depressive disorders. In: MURRAY, L.; COOPER, P. J. Postpartum depression: causes and consequences. New York: Springer-Verlag, 1997. p. 3-31.

PALMEIRA, R. Quatro tipos de ênfase melódica inicial no blues tradicional e suas formas de prolongação. ENCONTRO INTERNACIONAL DE TEORIA E ANÁLISE MUSICAL UNESP-USP-UNICAMP, 2., 2011. Disponível em: <http://www.eca.usp.br/etam/iiencontro/ANAIS\%20II\%20TEORIA\%20ANALIS E/12\%20Quatro\%20tipos\%20de\%20\%C3\%AAnfase\%20mel\%C3\%B3dica\%2 0inicial\%20no\%20blues\%20tradicional.pdf>. Acesso em: 3 jan. 2014.

PARKER, R. A mãe dividida: a experiência da ambivalência na maternidade. Rio de Janeiro: Record/Rosa dos Tempos, 1997.

PEREIRA, M. E. C. Pânico e desamparo: um estudo psicanalítico. São Paulo: Escuta, 2008. (Biblioteca de Psicopatologia Fundamental.) 
PITT, B. Maternity blues. The British Journal of Psychiatry, London: The Royal College of Psychiatrics, n. 122, p. 431-433, 1973.

. "Atypical" Depression Following Childbirth. The British Journal of Psychiatrics, London: The Royal College of Psychiatrics, n. 114, p. 13251335, 1968.

PRAT, R. Entre demais e muito pouco: a quadratura do círculo da parentalidade. Revista Brasileira de Psicanálise, v. 42, n. 4, p. 125-137, 2008.

RAPHAEL-LEFF, J. Gravidez: a história interior. Porto Alegre: Artes Médicas,1997.

REY, G. Pesquisa qualitativa em psicologia. São Paulo: Pioneira Thompson Learning, 2002.

ROCHETTE, J. La mélodie des émotions dans le post-partum immédiate: quarante jours pour accorder les violins. Spirale, n. 44, p. 85-93, 2007. - Transformation des souffrances de la dyade mère-bébé dans la première année post-partum: stratégies préventives pour um travail em réseau. Devenir, v. 19, p. 81-108, 2007b.

. Le temps du post-partum immediate. Une Clinique du "qui-vive" et de I'après coup. Neuropsychiatrie de I'Enfance de I'Adolescence, n. 53, p. 11-18, 2005.

. Le ritual, la mere et le bébé: un dispositive de soin en périnatalité, les groups de présentation de bébé. Revue de Psychothérapie

Psychanalytique de Groupe, v. 1, n. 40, p. 93-126, 2003.

ROCHETTE, J. et al. "Hunting for butterflies" in the immediate post-partum: reinforcing the framework of inter-agency care using observation according to Esther Bick's method. Infant Observation: International Journal of Infant Observation and Its Applications, v. 13, n. 2, p. 179-187, 2010.

ROHDE, L. A. et al. Maternity blues in Brazilian women. Acta Psychiatrica Scandinavica, n. 95, p. 231-235, 1997.

SCHWENGBER, D. D. S.; PICCININI, C. A. O impacto da depressão pós-parto para a interação mãe-bebê. Estudos de Psicologia, Campinas, v. 8, n. 3, p. 403411, 2003.

SILVA, M. C. P. (Org.); SOLIS-PONTON, L. (Dir.). Ser pai, ser mãe parentalidade: um desafio para o terceiro milênio. Uma homenagem internacional a Serge Lebovici. São Paulo: Casa do Psicólogo, 2004.

SOIFER, R. Psicologia da gravidez, parto e puerpério. Porto Alegre: Artes Médicas, 1992.

STERN, D.; BRUSCHWEILER-STERN, N. La naissance d'une mere.Traduit de l'anglais (États-Unis) par Claire Joly. Paris: Odile Jacob, 1998. 
STERN, D. A constelação da maternidade: o panorama da psicoterapia pais/bebê. Porto Alegre: Artes Médicas,1997.

SZEJER, M. Palavras para nascer: a escuta psicanalítica na maternidade. São Paulo: Casa do Psicólogo, 1999a.

. A escuta psicanalítica de bebês em maternidade. ABREP. Associação Brasileira para o Estudo do Psiquismo Pré e Perinatal. São Paulo: Casa do Psicólogo, 1999b.

. Uma abordagem psicanalítica da gravidez e do nascimento. In: CORRÊA FILHO, L.; CORREAA, M. E. G.; FRANÇA, P. S. (Orgs.) Novos olhares sobre a gestação e a criança até os 3 anos: saúde perinatal, educação e desenvolvimento do bebê. Brasília: LGE, 2002.

; STEWART, R. Nove meses na vida de uma mulher: uma abordagem psicanalítica da gravidez e do nascimento. São Paulo: Casa do Psicólogo, 1997.

TABORDA, W.; DEUTSCH, A. D’A. (Cons. Eds.). A bíblia da gravidez. Trad. Eliane Piereck. São Paulo: CMS, 2004.

TRINCA, W. Considerações sobre um modelo de pesquisa em Psicanálise. Psyché, São Paulo, ano IV, n. 10, p. 195-204, 2002.

TURATO, E. R. Métodos qualitativos e quantitativos na área da saúde: definições, diferenças e seus objetos de pesquisa. Revista Saúde Pública, v. 39, n. 3, p. 507-14, 2005.

WINNICOTT, D. W. A família afetada pela patologia depressiva. In: A família e o desenvolvimento individual. São Paulo: Martins Fontes, 2005a [1958].

. O valor da depressão. In: . Tudo começa em casa. São Paulo: Martins Fontes, 2005b [1963].

. A preocupação materna. In: escolhidas. Rio de Janeiro: Imago, 2000a [1956].

. A posição depressiva no desenvolvimento emocional normal. In: Da pediatria à psicanálise: obras escolhidas. Rio de Janeiro: Imago, 2000 b [1954].

YALOM, I. D.; LUND, D. T.; MOSS, R. H.; HAMBURG, D. A. "Postpartum blues" syndrome: a Description and Related Variables. Archives of General Psychiatry, v. 18, n. 1, p. 16-27, 1968. 


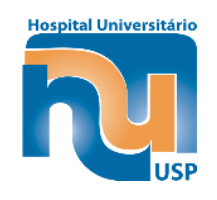

\section{ANEXO A \\ Termo de Consentimento Livre e Esclarecido \\ Título da Pesquisa: Caminhos da Tristeza Materna.}

Esta pesquisa tem como objetivo verificar a relação que a mãe estabelece com seu bebê, durante os três primeiros meses de vida deste, observando as possíveis manifestações de estados depressivos e seus impactos no vínculo mãe-bebê. A importância desse estudo está em auxiliar os profissionais da saúde a acolherem melhor a dupla mãe-bebê e a família no momento sensível do pós-parto.

O procedimento para a pesquisa compreende uma ou mais entrevistas a partir do início do terceiro trimestre da gestação. Após o nascimento do bebê, haverá outra entrevista com a mãe junto de seu bebê, na primeira semana após o parto, para posteriormente acompanharmos observando a relação da mãe com seu bebê mensalmente, de acordo com a disponibilidade da participante, até o terceiro mês de vida. Os encontros poderão se dar na residência da família ou em outro local de acordo com a preferência do participante e terão duração aproximada de uma hora cada um deles.

Sua participação é de caráter voluntário e poderá ser suspensa a qualquer momento anterior à publicação do trabalho final da Tese de doutorado, da qual essa pesquisa é parte. Os dados pessoais serão mantidos em sigilo absoluto como forma de preservar a imagem daqueles que colaborarem com a presente pesquisa, bem como, haverá o compromisso em manter todo o conteúdo da pesquisa e seus resultados em âmbito científico e acadêmico.

Reiteramos que o participante poderá, a qualquer momento, até a data de entrega do estudo, retirar seu consentimento a respeito da utilização de seus dados colhidos, sem que isso resulte em qualquer tipo de penalidade ou dano a si.

Todas as atividades desenvolvidas para a pesquisa não oferecem nenhum risco de dano à dimensão física, psíquica, moral, intelectual, social, cultural e espiritual à participante, durante ou após o término da pesquisa. Entretanto, após o estudo, caso seja detectada alguma necessidade, os participantes serão encaminhados para atendimento pertinente.

O participante poderá pedir esclarecimentos adicionais a qualquer tempo, sobre pontos que não tenham ficado devidamente esclarecidos. Todos os participantes preencherão um Termo de Consentimento Livre e Esclarecido, o qual será redigido em duas vias de igual teor, das quais uma ficará com o participante e outra com o pesquisador. 
Nome da pesquisadora: Cristiane da Silva Geraldo Folino CRP 06/38072-5 E-mail: cristianegf@usp.br

Nome da orientadora: Profa. Dra. Audrey Setton Lopes de Souza - CRP 06/5194 Email: asetton@uol.com.br

Pesquisa de Doutorado vinculada ao Departamento/ Área de Concentração: Pós-Graduação em Psicologia Escolar e do Desenvolvimento Humano do Instituto de Psicologia da Universidade de São Paulo.

CEP-HU Comitê de Ética em Pesquisa do Hospital Universitário da Universidade de São Paulo.

Endereço: Av. Prof. Lineu Prestes, 2565 - Cidade Universitária - CEP: 05508-000 - São Paulo - Telefone: 3091-9457-Fax: 3091-9452 -E-mail:cep@hu.usp.br

\section{Dados de Identificação do Sujeito da Pesquisa}

Nome:

Número do documento de identidade:

Sexo:

Idade*:

Data de nascimento:

Endereço:

Telefones:

Declaro que, após convenientemente esclarecido pelo pesquisador e ter entendido o que me foi explicado, consinto em participar de presente Projeto de Pesquisa.

Local e data:

Assinatura do sujeito da pesquisa:

Assinatura do pesquisador responsável:

Cristiane da Silva Geraldo Folino 
*Caso o sujeito for menor de idade, deverão ser preenchidos os campos abaixo por seu responsável legal:

Eu, autorizo a menor a ser participante Pesquisa de Doutorado intitulada "Caminhos da Tristeza Materna", vinculada ao Departamento/ Área de Concentração: Pós-Graduação em Psicologia Escolar e do Desenvolvimento Humano do Instituto de Psicologia da Universidade de São Paulo.

Nome do Responsável:

Número do documento de identidade:

Sexo:

Data de nascimento:

Endereço:

Telefones:

Local e data:

Assinatura do responsável pela menor: 


\section{ANEXO B}

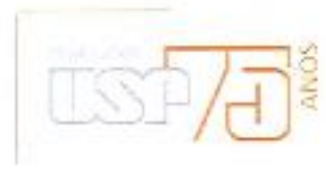

$S(\omega)$

\section{Cristiane da Silva Geraldo Folino}

Departamento de l'sicologia Escolar e do Desenvolvimento Humano Instituto de Psicologia

UNIVERSIDADE DE SÃO PAULO

REFERENTE: Projeto de Pesquisa "Camimhos da tristeza matema" - Orientadora: Profa. Dra. Audrey Setton Lopes de Souza - Pesquisadora Executante (Aluna): Cristiane da Silva Geraldo Folino - Registro CEP-HU/LSP: 1173/11 - SISNEP CAAE: $0055.0 .198 .000-11$.

Prezado(a) Senhor(a)

O Comitê de Ética em Pesquisa do Hospital Universitário da Liniversidade de São I'aulo, em reunião ordinúria realizada no dia 02 de março de 2012, aralisou o Projeto de Pesquisa acima citado, considerando-o como APROVADO, bem como o scu Termo de Consentimento Livre e Esclarecido.

Lembramos que cabe ao pesquisador elaborar e apresentar a este Comitê, rolatórios anuais (parciais ou final, em funçāo da duraçăo da pesquisa), de acordo com a Resolução n 196/96 do Conselho Nacional de Saúde, inciso DX.2, letra "c".

O primeiro relatório está previsto pała 02 de março de 2013.

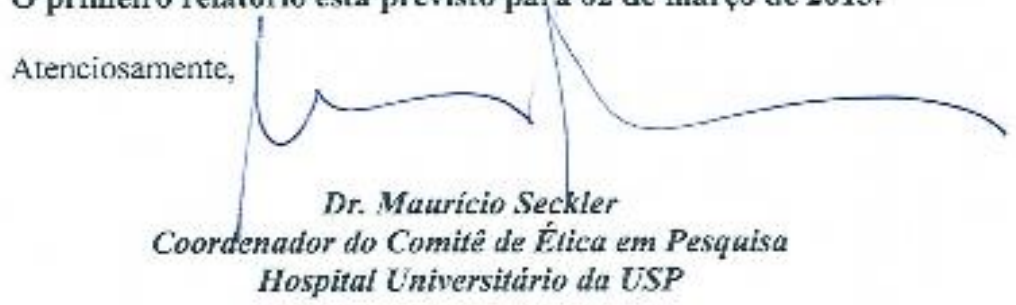

COMTTẺ DH ËICA EM PESQLIS, DO HOSPTTAL UNIVERSTT DRIO DA IS

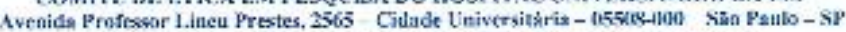

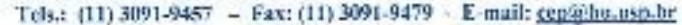

